\title{
Cobalt-Catalyzed Enantioselective Hydrogenation of Minimally Functionalized Alkenes: Isotopic Labeling Provides Insight into the Origin of Stereoselectivity and Alkene Insertion Preferences.
}

\author{
Max R. Friedfeld, ${ }^{a}$ Michael Shevlin, ${ }^{b}$ Grant W. Margulieux, ${ }^{a}$ Louis-Charles \\ Campeau, ${ }^{b}$ and Paul J. Chirik ${ }^{\mathrm{a}}$ \\ a. Department of Chemistry, Princeton University, Princeton, New Jersey, U. S. A. \\ 08544 \\ b. Merck Research Laboratories, Department of Process \& Analytical Chemistry, \\ Rahway, New Jersey, U. S. A. 07065 \\ pchirik@princeton.edu
}

Supporting Information 


\section{Table of Contents}

Experimental Section $\quad$ S3

General Considerations. S3

Alternative Synthesis of (S)- $\mathrm{CoCH}_{3} . \quad \mathrm{S} 4$

General Procedures for Catalytic Alkene Hydrogenation. S5

II. Synthesis and Characterization of Alkenes. S6

III. Characterization of Alkane Products. $\quad$ S35

IV. Substrate Optimization Tables. $\quad$ S55

V. Catalytic Hydrogenation of 1a with Precious Metal Catalysts. S57

VI. Deuterium Labelling Studies. $\quad S 60$

VII. Synthesis and Characterization of (S)-CoH. $\quad$ S81

VIII. Grignard Reagent Additions to (S)-CoCl. $\quad$ S82

IX. Representative NMR Spectra. $\quad$ S85

$\begin{array}{ll}X . \text { References. } & \mathbf{S 1 3 5}\end{array}$ 


\section{Experimental Section}

General Considerations. All air- and moisture-sensitive manipulations were carried out using standard high vacuum line, Schlenk or cannula techniques or in an M. Braun inert atmosphere drybox containing an atmosphere of purified nitrogen. The M. Braun drybox was equipped with a cold well designed for freezing samples in liquid nitrogen. Solvents for air- and moisture-sensitive manipulations were dried and deoxygenated using literature procedures.1 Deuterated solvents for NMR spectroscopy were distilled from sodium metal under an atmosphere of argon and stored over $4 \AA$ molecular sieves.

${ }^{1} \mathrm{H}$ NMR spectra were recorded on a Varian Inova 400 Spectrometer operating at 399.860 MHz or a Bruker AVANCE-500 equipped with a TCl cryoprobe optimized for ${ }^{1} \mathrm{H}$ detection operating at $500.62 \mathrm{MHz}$. All chemical shifts are reported relative to $\mathrm{SiMe}_{4}$

using ${ }^{1} \mathrm{H}$ (residual) chemical shifts of the solvent as a secondary standard. ${ }^{13} \mathrm{C}$ NMR spectra were recorded on a Bruker 500 spectrometer equipped with a DCH cryoprobe optimized for ${ }^{13} \mathrm{C}$ detection operating at $125.71 \mathrm{MHz} .{ }^{13} \mathrm{C}$ chemical shifts are reported relative to $\mathrm{SiMe}_{4}$ using chemical shifts of the solvent as a secondary standard where applicable.

High-resolution mass spectra were measured using an Agilent 6220 AccurateMass TOF LC/MS. The mass spectrometer was calibrated externally before each use with purine and the Agilent ES-TOF tuning mix (part number $=$ G1969-85000). These compounds were assigned a $(\mathrm{M}+\mathrm{H})^{+} \mathrm{m} / \mathrm{z}$ ratio of 121.050873 and 922.009798 respectively. Optical rotations were recorded on a Perkin Elmer Model 341 polarimeter (1-mL cell, $1 \mathrm{dm}$ path length); concentration (c) is in $\mathrm{g} / 100 \mathrm{~mL}$ and $[\alpha]_{\mathrm{D}}$ values are in degrees. Racemic alkanes were independently synthesized using either racemic catalyst or $5 \% \mathrm{Pd} / \mathrm{C}$ catalyst to obtain chiral analysis and for comparison to enantioselective catalytic experiments. 
Gas chromatography for the alkane products was performed on a Shimadzu GC2010 gas chromatograph. Chiral gas chromatography for the alkane products was performed on a Shimadzu GC-2010 gas chromatogram using a Supelco $30 \mathrm{~m} \times 0.25$ mm BETA DEX 120 capillary column as noted for each product. Supercritical fluid chromatography (SFC) was performed on a Berger Minigram equipped with a diode array UV detector $(\lambda=214-300 \mathrm{~nm})$ using a chiral column $(25 \mathrm{~cm})$ and guard column $(5$ $\mathrm{cm})$ as noted for each compound.

Single crystals suitable for X-ray diffraction were coated with polyisobutylene oil in a drybox, transferred to a nylon loop and then quickly transferred to the goniometer head of a Bruker X8 APEX2 DUO diffractometer equipped with a molybdenum X-ray tube $(\lambda=0.71073)$. Preliminary data revealed the crystal system. The data collection strategy was optimized for completeness and redundancy using the Bruker COSMO software suite. The space group was identified, and the data were processed using the Bruker SAINT+ program and corrected for absorption using SADABS. The structures were solved using direct methods (SHELXS) completed by subsequent Fourier synthesis and refined by full-matrix least-squares procedures.

\section{Alternative Synthesis of (S)- $\mathrm{CoCH}_{3}$.}

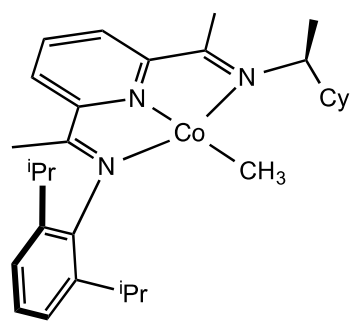

(S)-CoMe

A two-step preparation of $(\mathbf{S})-\mathrm{CoCH}_{3}$ from $(\boldsymbol{S})-\mathrm{CoCl}_{2}$ has previously been reported. ${ }^{2}$ In a nitrogen-filled glove box, a $250 \mathrm{~mL}$ round bottom flask was charged with a magnetic stir bar, $1.094 \mathrm{~g}$ (1.948 mmol) (S)- $\mathrm{CoCl}_{2}$, and $100 \mathrm{~mL}$ of diethyl ether. The flask was cooled 
in the cold well to $-95{ }^{\circ} \mathrm{C}$. Meanwhile, $2.65 \mathrm{~mL}$ MeLi (4.25 mmol, $1.6 \mathrm{M}$ in diethyl ether) was diluted in $10 \mathrm{~mL}$ diethyl ether and cooled to $-35^{\circ} \mathrm{C}$. The MeLi solution was added dropwise to the reaction flask, which was then allowed to warm to room temperature with stirring over the course of 3 hours, by which point the reaction mixture changed color to dark purple. Following solvent evaporation, the purple residue was dissolved in $50 \mathrm{~mL}$ of pentane and filtered through a pad of celite. The filtrated was concentrated to afford

$0.882 \mathrm{~g}\left(1.744 \mathrm{mmol}, 90 \%\right.$ yield) of (S)- $\mathrm{CoCH}_{3}$ as a dark purple solid. ${ }^{1} \mathrm{H}$ and ${ }^{13} \mathrm{C}$ NMR spectra are consistent with previously reported data. ${ }^{2}$

\section{General Procedures for Catalytic Alkene Hydrogenation.}

Procedure A: Catalytic Alkene Hydrogenation with (S)- $\mathrm{CoCH}_{3}$ at 4 atm. In a nitrogen-filled glovebox, a flame-dried, sealable thick-walled glass vessel was charged with $0.025 \mathrm{~g}(0.05 \mathrm{mmol})$ of $(\mathrm{S})-\mathrm{CoCH}_{3}, 1.0 \mathrm{mmol}$ of the desired substrate and the desired volume of solvent (diethyl ether or toluene). The vessel was sealed and attached to the high-vacuum line and then its contents were frozen in liquid nitrogen. Following evacuation of the headspace, the vessel was pressurized with $1 \mathrm{~atm}$ of hydrogen gas at $77 \mathrm{~K}$ and re-sealed. Upon warming to room temperature (at which point the pressure is $\sim 4 \mathrm{~atm}$ ), the purple solution was stirred for 18 hours at $25 \stackrel{\circ}{\circ} \mathrm{C}$. The vessel was then vented and diluted with $\sim 15 \mathrm{~mL}$ hexane. The reaction mixture was passed through a plug of silica, eluting with hexane. Following solvent evaporation, the alkane product was isolated and analyzed by chiral GC or SFC chromatography.

Procedure B: Catalytic Alkene Hydrogenation with $(S)-C_{1}$-CoMe at Higher (34-68 atm) Pressures of $\mathbf{H}_{2}$. In a nitrogen-filled glovebox, a $45 \mathrm{~mL}$ glass well was charged with $0.025 \mathrm{~g}(0.05 \mathrm{mmol})$ of $(\mathbf{S})-C_{1}-\mathrm{CoMe}, 1.0 \mathrm{mmol}$ of the desired substrate and $4 \mathrm{~mL}$ of 
solvent (diethyl ether or toluene). The glass well was charged into a $45 \mathrm{~mL}$ Parr reactor which was then sealed, pressurized to 68 atm (1000 psi) $\mathrm{H}_{2}$, vented, re-pressurized to $68 \mathrm{~atm}$, and vented to the desired pressure (68 or $34 \mathrm{~atm}$ ). The solution was mechanically stirred under the $\mathrm{H}_{2}$ pressure for 18 hours after which time the vessel was vented and the reaction mixture was diluted with $\sim 15 \mathrm{~mL}$ hexane. The reaction mixture was passed through a plug of silica, eluting with hexane. Following solvent evaporation, the alkane product was isolated and analyzed by chiral GC or SFC chromatography.

\section{Synthesis and Characterization of Alkenes.}
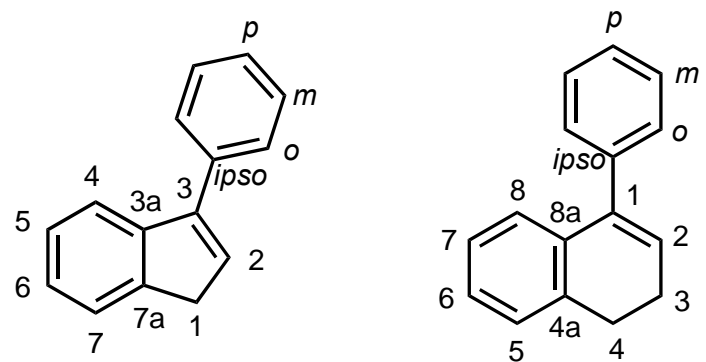

Figure S1. Numbering system for substituted indenes and dihydronaphthalenes.

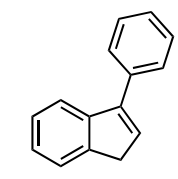

3-phenyl-1H-indene (1a). A 250-mL oven-dried schlenk flask was charged with $100 \mathrm{~mL}$ anhydrous tetrahydrofuran, a magnetic stir bar and $1.500 \mathrm{~g}$ (11.35 mmol) of 1 -indanone on a schlenk line. The reaction vessel was cooled to $-78 \stackrel{\circ}{\circ}$ and $17 \mathrm{~mL}$ of phenylmagnesium bromide (1 $\mathrm{M}$ in 2-Me-THF, $17 \mathrm{mmol}$ ) was added dropwise. The reaction vessel was allowed to warm to room temperature and stirred for an additional 6 hours at room temperature. The vessel was cooled to $0{ }^{\circ} \mathrm{C}$ and aqueous ammonium chloride $(1 \mathrm{~mL})$ was slowly added via syringe to quench the reaction. An additional $100 \mathrm{~mL}$ of water were then added upon complete consumption of the Grignard reagent. The reaction mixture was extracted with ethyl acetate $(2 \times 50 \mathrm{~mL})$. The organic layers were combined and washed with $100 \mathrm{~mL}$ of brine and dried with sodium sulfate. Following solvent removal, the crude alcohol was dissolved in toluene and $0.150 \mathrm{~g} p$ toluenesulfonic acid $(0.79 \mathrm{mmol})$ was added. The reaction was heated to reflux for 6 
hours with removal of water with a Dean-Stark apparatus. Following cooling and solvent evaporation, the residue was dissolved in $150 \mathrm{~mL}$ ethyl acetate and extracted with conc. aqueous $\mathrm{NaHCO}_{3}(100 \mathrm{~mL})$ and brine. The organics were dried over sodium sulfate and filtered and the solvent was removed. The crude product was purified via column chromatography using hexane as the eluent to afford $1.12 \mathrm{~g}(11.4 \mathrm{mmol}, 51 \%$ yield $)$ of 3phenyl-1 $\mathrm{H}$-indene as a clear oil. ${ }^{1} \mathrm{H}$ NMR $\left(500 \mathrm{MHz}, \mathrm{CDCl}_{3}, 23{ }^{\circ} \mathrm{C}\right): \delta 3.52\left(\mathrm{~d},{ }^{3} \mathrm{H}_{\mathrm{HH}}=1.6\right.$ $\mathrm{Hz}, 2 \mathrm{H}, 1$-indenyl $\left.\mathrm{CH}_{2}\right), 6.59\left(\mathrm{t},{ }^{3} \mathrm{~J}_{\mathrm{HH}}=2.0 \mathrm{~Hz}, 1 \mathrm{H}, 2\right.$-indenyl $\left.\mathrm{CH}\right), 7.27\left(\mathrm{t},{ }^{3} \mathrm{~J}_{\mathrm{HH}}=7.6 \mathrm{~Hz}\right.$, $1 \mathrm{H}, 5$ - or 6-indenyl $\mathrm{CH}), 7.33$, (t, ${ }^{3} \mathrm{~J}_{\mathrm{HH}}=7.5 \mathrm{~Hz}, 1 \mathrm{H}, 5$ - or 6-indenyl $\left.\mathrm{CH}\right), 7.36-7.40(\mathrm{~m}$, $1 \mathrm{H}, p-\mathrm{Ph}-\mathrm{CH}), 7.44-7.48(\mathrm{~m}, 2 \mathrm{H}, \mathrm{m}-\mathrm{Ph}-\mathrm{CH}), 7.55\left(\mathrm{~d},{ }^{3} \mathrm{~J}_{\mathrm{HH}}=7.3 \mathrm{~Hz}, 1 \mathrm{H}, 4-\right.$ or 7-indenyl $\mathrm{CH}$ ), 7.59-7.63 (overlapping $\mathrm{m}, 3 \mathrm{H}, \mathrm{o}-\mathrm{Ph}-\mathrm{CH}$ and 4- or 7-indenyl $\mathrm{CH}$ ). $\left\{{ }^{1} \mathrm{H}\right\}^{13} \mathrm{C}$ NMR (126 $\left.\mathrm{MHz}, \mathrm{CDCl}_{3}, 2{ }^{\circ} \mathrm{C}\right): \delta 38.41,120.52,124.33,125.05,126.35,127.77,127.92,128.77$, 131.18, 136.35, 144.11, 144.97, 145.38. ${ }^{1} \mathrm{H}$ and ${ }^{13} \mathrm{C}$ NMR spectra are consistent with previously reported data. ${ }^{3}$

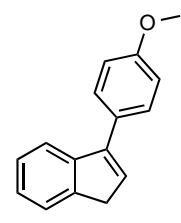

3-(p-methoxyphenyl)-1H-indene (1b). Following a modified procedure by Erker et. al, ${ }^{4}$ a $250-\mathrm{mL}$ oven-dried schlenk flask was charged with a magnetic stir bar and assembled on a schlenk line. To the flask was added $10 \mathrm{~mL}$ hexane and $17 \mathrm{~mL} n$-butyllithium $(2.5 \mathrm{M}$ in hexane, $42.5 \mathrm{mmol})$ via cannula transfer. The flask was equipped with a dropping funnel and cooled to $-78^{\circ} \mathrm{C}$. The dropping funnel was charged with $9.95 \mathrm{~g}(42.5 \mathrm{mmol}) 4$-iodoanisol dissolved in $50 \mathrm{~mL}$ diethyl ether and this solution was added to the schlenk flask dropwise. Following the addition, the reaction was stirred for 20 minutes while the dropping funnel was charged with $5.62 \mathrm{~g}(42.5 \mathrm{mmol})$ of 1 -indanone in $50 \mathrm{~mL}$ of diethyl ether. The 1 -indanone solution was then added dropwise over the course of 20 minutes. The reaction was allowed to warm to room temperature over the course of 4 hours and was then hydrolyzed with 50 $\mathrm{mL}$ of saturated aqueous ammonium chloride solution. The reaction was extracted with ethyl acetate $(2 \times 100 \mathrm{~mL})$ and the organics were washed with brine and dried over 
sodium sulfate. Following solvent removal, the crude alcohol was dissolved in toluene and $0.300 \mathrm{~g} p$-toluenesulfonic acid $(0.158 \mathrm{mmol})$ was added. The reaction was heated to reflux for 6 hours with removal of water with a Dean-Stark apparatus. Following cooling and solvent evaporation, the residue was dissolved in $150 \mathrm{~mL}$ ethyl acetate and extracted with conc. aqueous $\mathrm{NaHCO}_{3}(100 \mathrm{~mL})$ and brine. The organics were dried over sodium sulfate and filtered and the solvent was removed. The crude product was purified via column chromatography to afford $5.097 \mathrm{~g}(22.9 \mathrm{mmol}, 54 \%$ yield $)$ of 3 -( $p$ methoxyphenyl)- $1 \mathrm{H}$-indene (1b) as a white solid. ${ }^{1} \mathrm{H}$ NMR (500 MHz, $\left.\mathrm{CDCl}_{3}, 23{ }^{\circ} \mathrm{C}\right): \delta$ $3.50\left(\mathrm{~d},{ }^{3} \mathrm{JHH}_{\mathrm{HH}}=2.1 \mathrm{~Hz}, 2 \mathrm{H}, 1\right.$-indenyl $\left.\mathrm{CH}_{2}\right), 3.87\left(\mathrm{~s}, 3 \mathrm{H}, \mathrm{OCH}_{3}\right), 6.52\left(\mathrm{t},{ }^{3} \mathrm{~J}_{\mathrm{HH}}=2.2 \mathrm{~Hz}, 1 \mathrm{H}\right.$, 3-indenyl $\mathrm{CH}$ ), $7.00\left(\mathrm{~m}, 2 \mathrm{H}\right.$, aryl $\left.\mathrm{CH}_{2}\right), 7.26\left(\mathrm{dt},{ }^{3} \mathrm{JHH}_{\mathrm{HH}}=7.6 \mathrm{~Hz},{ }^{4} \mathrm{~J}_{\mathrm{HH}}=0.9 \mathrm{~Hz}\right.$, 5- or 6indenyl $\mathrm{CH}$ ), 7.33 (dt, ${ }^{3} \mathrm{~J}_{\mathrm{HH}}=7.4 \mathrm{~Hz},{ }^{4} \mathrm{~J}_{\mathrm{HH}}=0.9 \mathrm{~Hz}$, 5- or 6-indenyl $\mathrm{CH}$ ), 7.53-7.57 (overlapping $\mathrm{m}, 3 \mathrm{H}$, aryl $\mathrm{CH}_{2}$ and 4- or 7-indenyl), $7.59\left(\mathrm{~d},{ }^{3} \mathrm{~J}_{\mathrm{HH}}=7.6 \mathrm{~Hz}\right.$, 4- or 7-indenyl $\mathrm{CH}) \cdot\left\{{ }^{1} \mathrm{H}{ }^{13} \mathrm{C}\right.$ NMR $\left(126 \mathrm{MHz}, \mathrm{CDCl}_{3}, 23{ }^{\circ} \mathrm{C}\right): \delta 38.28,55.54,114.18,120.46,124.29$, $124.95,126.31,128.90,129.02,130.09,144.33,144.80,145.02,159.33 .{ }^{1} \mathrm{H}$ and ${ }^{13} \mathrm{C}$ NMR spectra are consistent with previously reported data. ${ }^{56}$

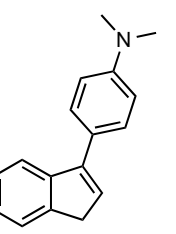

3-(p-dimethylaminophenyl)-1H-indene (1c). A schlenk flask was charged with a magnetic stir bar, $7.36 \mathrm{~g}$ (303 mmol) of magnesium turnings, and 150 $\mathrm{mL}$ tetrahydrofuran and assembled on a schlenk line with a dropping funnel. A $30 \mathrm{~mL}$ tetrahydrofuran solution of $7.27 \mathrm{~g}(36 \mathrm{mmol})$ of 4-bromo- $\mathrm{N}, \mathrm{N}$-dimethylaniline was added dropwise over the course of 90 minutes ensuring the temperature stayed below $30 \stackrel{\circ}{ } \mathrm{C}$. After addition, the reaction was stirred for 2 hours and then cooled to $0 \stackrel{\circ}{ } \mathrm{C}$. A $30 \mathrm{~mL}$ tetrahydrofuran solution of $4.00 \mathrm{~g}(30 \mathrm{mmol})$ of 1 -indanone was added to the dropping funnel, which was then added dropwise to the reaction flask over the course of 20 minutes. Following warming to room temperature, the reaction was stirred overnight and slowly hydrolyzed with $50 \mathrm{~mL}$ of saturated aqueous ammonium chloride followed by addition of $100 \mathrm{~mL}$ water. The reaction was extracted with ethyl acetate $(2 \times 100 \mathrm{~mL})$ 
and the organics were washed with brine and dried over sodium sulfate. Following solvent removal, the crude alcohol was dissolved in toluene and $0.300 \mathrm{~g} p$ toluenesulfonic acid $(0.158 \mathrm{mmol})$ was added. The reaction was heated to reflux for 6 hours with removal of water with a Dean-Stark apparatus. Following cooling and solvent evaporation, the residue was dissolved in $150 \mathrm{~mL}$ ethyl acetate and extracted with concentrated aqueous $\mathrm{NaHCO}_{3}(100 \mathrm{~mL})$ and brine. The organics were dried over sodium sulfate and filtered and the solvent was removed. The crude product was purified via column chromatography and triturated with $20 \mathrm{~mL}$ pentane to afford $4.05 \mathrm{~g}(17 \mathrm{mmol}$, $57 \%$ yield) of 3-( $p$-dimethylaminophenyl)- $1 H$-indene (1c) as an off-white solid. ${ }^{1} \mathrm{H}$ NMR $\left(500 \mathrm{MHz}, \mathrm{CDCl}_{3}, 23 \stackrel{\circ}{\circ} \mathrm{C}\right): \delta 3.04\left(\mathrm{~s}, 6 \mathrm{H}, \mathrm{N}\left(\mathrm{CH}_{3}\right)_{2}\right), 3.53\left(\mathrm{~d},{ }^{3} \mathrm{~J}_{\mathrm{HH}}=2.1 \mathrm{~Hz}, 2 \mathrm{H}, 1\right.$-indenyl $\left.\mathrm{CH}_{2}\right), 6.52\left(\mathrm{t},{ }^{3} \mathrm{~J}_{\mathrm{HH}}=2.2 \mathrm{~Hz}, 1 \mathrm{H}, 2\right.$-indenyl $\left.\mathrm{CH}\right), 6.87\left(\mathrm{~m}, 2 \mathrm{H}\right.$, aryl CH), $7.29\left(\mathrm{t},{ }^{3} \mathrm{JHH}_{\mathrm{HH}}=7.1\right.$ $\mathrm{Hz}, 1 \mathrm{H}, 5$ - or 6-indenyl $\mathrm{CH}$ ), $7.37\left(\mathrm{t},{ }^{3} \mathrm{~J}_{\mathrm{HH}}=7.4 \mathrm{~Hz}, 1 \mathrm{H}, 5\right.$ - or 6-indenyl $\mathrm{CH}$ ), 7.55-7.59 (overlapping $\mathrm{m}, 3 \mathrm{H}$, aryl $\mathrm{CH}$ and 4- or 7-indenyl $\mathrm{CH}), 7.69\left(\mathrm{~d},{ }^{3} \mathrm{~J}_{\mathrm{HH}}=7.6 \mathrm{~Hz}, 1 \mathrm{H}, 4-\right.$ or 7 indenyl $\mathrm{CH}) \cdot\left\{{ }^{1} \mathrm{H}\right\}^{13} \mathrm{C}$ NMR $\left(126 \mathrm{MHz}, \mathrm{CDCl}_{3}, 23^{\circ} \mathrm{C}\right): \delta 38.19,40.79,112.68,120.60$, $124.19,124.58,124.73,126.19,128.63,128.88,144.40,145.06,145.13,150.25 .{ }^{1} \mathrm{H}$ and ${ }^{13} \mathrm{C}$ NMR spectra are consistent with previously reported data. ${ }^{7}$

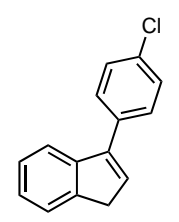

3-(p-chlorophenyl)-1 $H$-indene (1d). On a schlenk line, a $250-\mathrm{mL}$ oven-dried schlenk flask was charged with $100 \mathrm{~mL}$ anhydrous tetrahydrofuran, a magnetic stir bar and $25 \mathrm{~mL}$ of $p$-chlorophenylmagnesium bromide $(1 \mathrm{M}$ in 2Me-THF, $25 \mathrm{mmol}$ ). The reaction vessel was stirred and cooled to $0{ }^{\circ} \mathrm{C}$ and $3.30 \mathrm{~g}$ (25 mmol) 1-indanone was slowly added. The reaction was allowed to warm to room temperature over 12 hours. The vessel was cooled to $0 \stackrel{\circ}{ } \mathrm{C}$ and slowly hydrolyzed with aqueous ammonium chloride $(10 \mathrm{~mL})$. An additional $100 \mathrm{~mL}$ of water was then added upon complete consumption of the Grignard reagent. The reaction mixture was extracted with ethyl acetate $(2 \times 50 \mathrm{~mL})$. The organic layers were combined and washed with 100 $\mathrm{mL}$ of brine and dried with sodium sulfate. Following solvent removal, the crude alcohol 
was dissolved in toluene and $0.3 \mathrm{~g}$ p-toluenesulfonic acid $(0.16 \mathrm{mmol})$ was added. The reaction was heated to reflux for 6 hours with removal of water with a Dean-Stark apparatus. Following cooling and solvent evaporation, the residue was dissolved in 150 $\mathrm{mL}$ ethyl acetate and extracted with conc. aqueous $\mathrm{NaHCO}_{3}(100 \mathrm{~mL})$ and brine $(50$ $\mathrm{mL}$ ). The organics were dried over sodium sulfate and filtered and the solvent was removed. The crude product was purified via column chromatography using hexane as the eluent $\left(R_{f}=0.44\right)$ to afford $2.87 \mathrm{~g}(12.7 \mathrm{mmol}, 51 \%$ yield $)$ of 3 -(p-chlorophenyl $)-1 \mathrm{H}$ indene (1d) as a white solid. ${ }^{1} \mathrm{H}$ NMR $\left(500 \mathrm{MHz} \mathrm{CDCl}_{3}, 23{ }^{\circ} \mathrm{C}\right): \delta 3.52\left(\mathrm{~d},{ }^{3} \mathrm{~J}_{\mathrm{HH}}=2.2 \mathrm{~Hz}\right.$, $2 \mathrm{H}, 1$-indenyl $\left.\mathrm{CH}_{2}\right), 6.59\left(\mathrm{t},{ }^{3} \mathrm{~J}_{\mathrm{HH}}=2.2 \mathrm{~Hz}, 1 \mathrm{H}, 2\right.$-indenyl $\left.\mathrm{CH}\right), 7.29\left(\mathrm{t},{ }^{3} \mathrm{~J}_{\mathrm{HH}}=7.3 \mathrm{~Hz}, 5\right.$ - or 6-indenyl $\mathrm{CH}$ ), $7.35\left(\mathrm{t},{ }^{3} \mathrm{~J}_{\mathrm{HH}}=7.5 \mathrm{~Hz}\right.$, 5- or 6-indenyl $\left.\mathrm{CH}\right), 7.42-7.46(\mathrm{~m}, 2 \mathrm{H}$, aryl $\mathrm{CH})$, 7.53-7.57 (overlapping $\mathrm{m}$, aryl $\mathrm{CH}$, 4- and 7-indenyl $\mathrm{CH}$ ). $\left\{{ }^{1} \mathrm{H}\right\}^{13} \mathrm{C} \mathrm{NMR}\left(126 \mathrm{MHz}, \mathrm{CDCl}_{3}\right.$, $\left.23{ }^{\circ} \mathrm{C}\right): \delta 38.43,120.29,124.41,125.25,126.45,128.97,129.18,131.61,133.54$, $134.75,143.71,144.28,144.87 .{ }^{1} \mathrm{H}$ and ${ }^{13} \mathrm{C}$ NMR spectra are consistent with previously reported data. ${ }^{8} \mathrm{HR}-\mathrm{MS}$ (+El): Calc'd for: $\mathrm{C}_{15} \mathrm{H}_{11} \mathrm{Cl},[\mathrm{M}]^{\circ+}, \mathrm{m} / z$ 226.0544. Found $\mathrm{m} / \mathrm{z}$ 226.055.

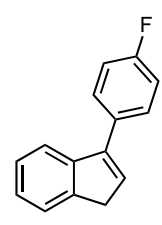

3-(p-fluorophenyl)-1H-indene (1e). On a schlenk line, a 250-mL oven-dried schlenk flask was charged with $100 \mathrm{~mL}$ anhydrous tetrahydrofuran, a magnetic stir bar and $20 \mathrm{~mL}$ of $p$-fluorophenylmagnesium bromide $(2 \mathrm{M}$ in diethyl ether, $40 \mathrm{mmol}$ ). The reaction vessel was stirred and cooled to $0{ }^{\circ} \mathrm{C}$ and $4.41 \mathrm{~g}$ (33.3 mmol) 1-indanone was slowly added. The reaction was allowed to warm to room temperature over 12 hours. The vessel was cooled to $0{ }^{\circ} \mathrm{C}$ and slowly hydrolyzed with aqueous ammonium chloride $(10 \mathrm{~mL})$. An additional $100 \mathrm{~mL}$ of water was then added upon complete consumption of the Grignard reagent. The reaction mixture was extracted with ethyl acetate $(2 \times 50 \mathrm{~mL})$. The organic layers were combined and washed with 100 $\mathrm{mL}$ of brine and dried with sodium sulfate. Following solvent removal, the crude alcohol was dissolved in toluene and $0.3 \mathrm{~g}$ p-toluenesulfonic acid $(0.16 \mathrm{mmol})$ was added. The 
reaction was heated to reflux for 6 hours with removal of water with a Dean-Stark apparatus. Following cooling and solvent evaporation, the residue was dissolved in 150 $\mathrm{mL}$ ethyl acetate and extracted with conc. aqueous $\mathrm{NaHCO}_{3}(100 \mathrm{~mL})$ and brine $(50$ $\mathrm{mL}$ ). The organics were dried over sodium sulfate and filtered and the solvent was removed. The crude product was purified via column chromatography using hexane as the eluent $\left(R_{f}=0.43\right)$ to afford $2.00 \mathrm{~g}(9.5 \mathrm{mmol}, 29 \%$ yield $)$ of 3 -( $p$-fluorophenyl $)-1 \mathrm{H}$ indene (1e) as a clear oil. ${ }^{1} \mathrm{H}$ NMR $\left(500 \mathrm{MHz}, \mathrm{CDCl}_{3}, 23 \stackrel{\circ}{\circ}\right): \delta 3.51\left(\mathrm{~d},{ }^{3} \mathrm{~J}_{\mathrm{HH}}=2.2 \mathrm{~Hz}\right.$, $2 \mathrm{H}, 1$-indenyl $\left.\mathrm{CH}_{2}\right), 6.55\left(\mathrm{t},{ }^{3} \mathrm{~J}_{\mathrm{HH}}=2.2 \mathrm{~Hz}, 1 \mathrm{H}, 2\right.$-indenyl $\left.\mathrm{CH}\right), 7.15(\mathrm{~m}, 2 \mathrm{H}$, aryl $\mathrm{CH}), 7.27$ $\left(\mathrm{t},{ }^{3} \mathrm{~J}_{\mathrm{HH}}=7.5 \mathrm{~Hz}, 1 \mathrm{H}, 5\right.$ - or 6-indenyl $\mathrm{CH}$ ), $7.33\left(\mathrm{t},{ }^{3} \mathrm{~J}_{\mathrm{HH}}=7.5 \mathrm{~Hz}, 1 \mathrm{H}, 5\right.$ - or 6-indenyl $\mathrm{CH}$ ), 7.52-7.59 (overlapping $\mathrm{m}, 4 \mathrm{H}, 2$ aryl $\mathrm{CH}$ and 4- and 7-indenyl $\mathrm{CH}$ ). $\left\{{ }^{1} \mathrm{H}\right\}^{13} \mathrm{C}$ NMR (126 $\mathrm{MHz}, \mathrm{CDCl}_{3}, 23{ }^{\circ} \mathrm{C}$ ): $\delta 38.37$ (s, 1-indenyl $\left.\mathrm{CH}_{2}\right), 115.69\left(\mathrm{~d},{ }^{2} J_{\mathrm{CF}}=21.4 \mathrm{~Hz}, m\right.$-aryl $\left.\mathrm{CH}\right)$, 120.30 (s, indenyl $\mathrm{CH}$ ), 124.38 (s, indenyl $\mathrm{CH}$ ), 125.17 (s, indenyl $\mathrm{CH}$ ), 126.42 (s, indenyl $\mathrm{CH}$ ), 129.48 (d, ${ }^{3} \mathrm{~J}_{\mathrm{CF}}=7.9 \mathrm{~Hz}$, o-aryl $\mathrm{CH}$ ), 131.14 (s, 2-indenyl $\mathrm{CH}$ ), 132.35 (d, ${ }^{4} J_{\mathrm{CF}}=3.3 \mathrm{~Hz}$, ipso-aryl C), 143.97 (s, indenyl C), 144.37 (s, 1-indenyl C), 144.89 (s, indenyl C) 162.54 (d, ${ }^{1} J_{C F}=246.3 \mathrm{~Hz}, p$-aryl CF). HR-MS (+El): Calc'd for: $\mathrm{C}_{15} \mathrm{H}_{11} \mathrm{~F}$, $[\mathrm{M}]^{\bullet+}, m / z 210.0839$. Found $m / z 210.0839$.

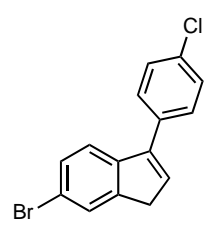

3-(p-fluorophenyl)-6-bromo-1H-indene (1f). On a schlenk line, a 250-mL oven-dried schlenk flask was charged with $100 \mathrm{~mL}$ anhydrous tetrahydrofuran, a magnetic stir bar and $25 \mathrm{~mL}$ of $p$ chlorophenylmagnesium bromide (1 $\mathrm{M}$ in 2-Me-THF, $25 \mathrm{mmol})$. The reaction vessel was stirred and cooled to $0^{\circ} \mathrm{C}$ and $5.03 \mathrm{~g}$ (23.8 mmol) 6-bromo-1-indanone was slowly added. The reaction was allowed to warm to room temperature over 12 hours. The vessel was cooled to $0 \stackrel{\circ}{ } \mathrm{C}$ and slowly hydrolyzed with aqueous ammonium chloride (10 $\mathrm{mL}$ ). An additional $100 \mathrm{~mL}$ of water was then added upon complete consumption of the Grignard reagent. The reaction mixture was extracted with ethyl acetate $(2 \times 50 \mathrm{~mL})$. The organic layers were combined and washed with $100 \mathrm{~mL}$ of brine and dried with 
sodium sulfate. Following solvent removal, the crude alcohol was dissolved in toluene and $0.3 \mathrm{~g}$ p-toluenesulfonic acid $(0.16 \mathrm{mmol})$ was added. The reaction was heated to reflux for 3 hours with removal of water with a Dean-Stark apparatus. Following cooling and solvent evaporation, the residue was suspended in $200 \mathrm{ml}$ hexane and filtered through a pad of celite, eluting with hexane to remove unidentified insoluble material. The filtrated was concentrated and the crude alkene product was purified via column chromatography using hexane as the eluent $\left(R_{\mathrm{f}}=0.68\right)$ to afford $2.904 \mathrm{~g}(9.50 \mathrm{mmol}$, $40 \%$ yield) of 3-( $p$-chlorophenyl)-6-bromo- $1 H$-indene (1f) as an off-white solid. ${ }^{1} \mathrm{H}$ NMR $\left(500 \mathrm{MHz}, \mathrm{CDCl}_{3}, 23^{\circ} \mathrm{O}\right): \delta 3.49\left(\mathrm{~d},{ }^{3} \mathrm{~J}_{\mathrm{HH}}=2.2 \mathrm{~Hz}, 2 \mathrm{H}, 1\right.$-indenyl $\left.\mathrm{CH}_{2}\right), 6.56\left(\mathrm{t},{ }^{3} \mathrm{JHH}_{\mathrm{H}}=2.2\right.$ $\mathrm{Hz}, 1 \mathrm{H}, 2$-indenyl $\mathrm{CH}$ ), $7.37\left(\mathrm{~d},{ }^{3} \mathrm{~J}_{\mathrm{HH}}=8.2 \mathrm{~Hz}, 1 \mathrm{H}, 4\right.$-indenyl $\mathrm{CH}$ ), 7.41-7.47 (overlapping $\mathrm{m}, 3 \mathrm{H}, 5$-indenyl $\mathrm{CH}$, aryl $\mathrm{CH}), 7.47-7.50(\mathrm{~m}, 2 \mathrm{H}$, aryl $\mathrm{CH}), 7.66\left(\mathrm{~d},{ }^{4} \mathrm{~J}_{\mathrm{HH}}=1.6 \mathrm{~Hz}, 7\right.$ indenyl CH). $\left\{{ }^{1} \mathrm{H}\right\}^{13} \mathrm{C}$ NMR (126 MHz, $\left.\mathrm{CDCl}_{3}, 23^{\circ} \mathrm{C}\right): \delta 38.2$ 8, 119.48, 121.50, 127.66, 129.08, 129.09, 129.52, 131.77, 133.84, 134.20, 142.71, 143.81, 146.91. HR-MS (+El): Calc'd for: $\mathrm{C}_{15} \mathrm{H}_{10} \mathrm{ClBr}$, [M] ${ }^{+}, \mathrm{m} / \mathrm{z}$ 303.9649. Found $\mathrm{m} / \mathrm{z} 303.9646$.

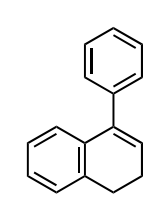

1-phenyl-3,4-dihydronaphthalene (1-phenyl-dialin, 3a). A 250-mL ovendried schlenk flask was charged with $100 \mathrm{~mL}$ anhydrous tetrahydrofuran, a magnetic stir bar and $25 \mathrm{~mL}$ of phenylmagnesium bromide (1 M in 2-Me-THF, $25 \mathrm{mmol}$ ) via cannula transfer. The reaction vessel was cooled to $-78{ }^{\circ} \mathrm{C}$ and $3.05 \mathrm{~g}$ (20.8 mmol) 1-tetralone was added dropwise. The reaction vessel was allowed to warm to room temperature and stirred for an additional 6 hours at room temperature. The vessel was cooled to $0 \stackrel{\circ}{ } \mathrm{C}$ and aqueous ammonium chloride $(10 \mathrm{~mL})$ was slowly added via syringe to quench the reaction. An additional $100 \mathrm{~mL}$ of water were then added upon complete consumption of the Grignard reagent. The reaction mixture was extracted with ethyl acetate $(2 \times 50 \mathrm{~mL})$. The organic layers were combined and washed with $100 \mathrm{~mL}$ of brine and dried with sodium sulfate. Following solvent removal, the crude alcohol was dissolved in toluene and $0.150 \mathrm{~g} p$-toluenesulfonic acid $(0.79 \mathrm{mmol})$ was added. The 
reaction was heated to reflux for 6 hours with removal of water with a Dean-Stark apparatus. Following cooling and solvent evaporation, the residue was dissolved in 150 $\mathrm{mL}$ ethyl acetate and extracted with conc. aqueous $\mathrm{NaHCO}_{3}(100 \mathrm{~mL})$ and brine. The organics were dried over sodium sulfate and filtered and the solvent was removed. The crude product was purified via column chromatography using hexane as the eluent to afford $1.56 \mathrm{~g}$ (7.56 mmol, 36\% yield) of 1-phenyl-3,4-dihydronaphthalene, 3a, as a clear oil. ${ }^{1} \mathrm{H}$ NMR (500 MHz, $\left.\mathrm{CDCl}_{3}, 23 \stackrel{\circ}{\circ}\right): \delta 2.42\left(\mathrm{~m}, 2 \mathrm{H}\right.$, allylic $\left.\mathrm{CH}_{2}\right), 2.87\left(\mathrm{t},{ }^{3} \mathrm{~J}_{\mathrm{HH}}=8.0 \mathrm{~Hz}\right.$, benzylic $\left.\mathrm{CH}_{2}\right), 6.10\left(\mathrm{t},{ }^{3} \mathrm{~J}_{\mathrm{HH}}=4.6 \mathrm{~Hz}, 1 \mathrm{H}\right.$, alkenyl $\left.\mathrm{CH}\right), 7.01\left(\mathrm{~d},{ }^{3} \mathrm{~J}_{\mathrm{HH}}=7.6 \mathrm{~Hz}\right.$, aryl $\left.\mathrm{CH}\right)$, $7.12\left(\mathrm{t},{ }^{3} \mathrm{~J}_{\mathrm{HH}}=7.5 \mathrm{~Hz}, 1 \mathrm{H}\right.$, aryl $\left.\mathrm{CH}\right), 7.17\left(\mathrm{t},{ }^{3} \mathrm{~J}_{\mathrm{HH}}=7.3 \mathrm{~Hz}\right.$, aryl $\left.\mathrm{CH}\right), 7.21\left(\mathrm{~d},{ }^{3} \mathrm{~J}_{\mathrm{HH}}=7.3\right.$ $\mathrm{Hz}, 1 \mathrm{H}$, aryl $\mathrm{CH}$ ), 7.31-7.41 (overlapping $\mathrm{m}, \mathrm{o}^{-}, \mathrm{m}$-, and $p$-phenyl $\mathrm{CH}$ ). $\left\{{ }^{1} \mathrm{H}\right\}^{13} \mathrm{C}$ NMR (126 $\left.\mathrm{MHz}, \mathrm{CDCl}_{3}, 23{ }^{\circ} \mathrm{C}\right): 23.74,28.51,125.63,126.40,127.17,127.28,127.75,127.87$, 128.42, 128.94, 135.50, 136.99, 140.07, 140.97. ${ }^{1} \mathrm{H}$ and ${ }^{13} \mathrm{C}$ NMR spectra are consistent with previously reported data. ${ }^{9}$

\section{1-(p-methoxyphenyl)-3,4-dihydronaphthalene (1-(p-methoxyphenyl)-dialin}

3b). A $250-\mathrm{mL}$ oven-dried schlenk flask was charged with $50 \mathrm{~mL}$ anhydrous diethyl ether, a magnetic stir bar and $4.816 \mathrm{~g}$ (20.6 mmol) p-iodoanisole. The reaction vessel was cooled to $-78 \stackrel{\circ}{\circ}$ and $8.2 \mathrm{~mL}$ of $n$-butyllithium $(20.6 \mathrm{mmol}, 2.5 \mathrm{M}$ in hexane) was added dropwise via cannula transfer. Then, $3.01 \mathrm{~g}(20.6 \mathrm{mmol})$ of 1 tetralone was added dropwise. The reaction vessel was stirred at $-78{ }^{\circ} \mathrm{C}$ for 20 minutes, then allowed to warm to room temperature for 3 hours. The vessel was cooled to $0 \stackrel{\circ}{C}$ and aqueous ammonium chloride $(10 \mathrm{~mL})$ was slowly added via syringe to quench the reaction. An additional $100 \mathrm{~mL}$ of water were then added. The reaction mixture was extracted with ethyl acetate $(2 \times 50 \mathrm{~mL})$. The organic layers were combined and washed with $100 \mathrm{~mL}$ of brine and dried with sodium sulfate. Following solvent removal, the crude alcohol was dissolved in $30 \mathrm{~mL}$ dichloromethane and $0.150 \mathrm{~g}$ p-toluenesulfonic acid (0.79 mmol) was added. The reaction flask was stirred for 4 hours at room temperature. 
The reaction mixture was then diluted with $50 \mathrm{~mL}$ dichloromethane and extracted with concentrated aqueous $\mathrm{NaHCO}_{3}$. The organic layer was washed with $50 \mathrm{~mL}$ brine and dried over sodium sulfate. Following filtration, the filtrate was concentrated to an oil which, upon standing at room temperature, furnished $1.607 \mathrm{~g}(6.8 \mathrm{mmol})$ of clear crystals of 1-(p-methoxyphenyl)-3,4-dihydronaphthalene (3b). The mother liquor was layered with pentane and cooled to $0{ }^{\circ} \mathrm{C}$, furnishing $0.75 \mathrm{~g}(3.2 \mathrm{mmol})$ of a second crop of clear crystals for an overall yield of $49 \% .{ }^{1} \mathrm{H}$ NMR $\left(500 \mathrm{MHz}, \mathrm{CDCl}_{3}, 23 \stackrel{\circ}{\circ} \mathrm{C}\right): \delta 2.40(\mathrm{~m}$, $2 \mathrm{H}$, 3-dihydronaphthyl $\left.\mathrm{CH}_{2}\right), 2.85$ (m, 2H, 4-dihydronaphthyl $\mathrm{CH}_{2}$ ), $3.85\left(\mathrm{~s}, 3 \mathrm{H}, \mathrm{OCH}_{3}\right.$ ), $6.06\left(\mathrm{t},{ }^{3} \mathrm{JHH}_{\mathrm{HH}}=4.6 \mathrm{~Hz}, 1 \mathrm{H}\right.$, alkenyl $\left.\mathrm{CH}\right), 6.92(\mathrm{~m}, 2 \mathrm{H}, m$-aryl $\mathrm{CH}), 7.03\left(\mathrm{~d},{ }^{3} \mathrm{JHH}_{\mathrm{HH}}=7.5 \mathrm{~Hz}\right.$, $1 \mathrm{H}, 5$ - or 8-dihydronaphthyl $\mathrm{CH}), 7.12\left(\mathrm{dt},{ }^{3} \mathrm{JHH}_{\mathrm{HH}}=7.3 \mathrm{~Hz},{ }^{4} \mathrm{~J}_{\mathrm{HH}}=1.2 \mathrm{~Hz}, 1 \mathrm{H}, 6\right.$ - or 7 dihydronaphthyl $\mathrm{CH}$ ), $7.16\left(\mathrm{dt},{ }^{3} \mathrm{~J}_{\mathrm{HH}}=7.3 \mathrm{~Hz},{ }^{4} \mathrm{~J}_{\mathrm{HH}}=1.3 \mathrm{~Hz}, 1 \mathrm{H}, 6\right.$ - or 7-dihydronaphthyl $\mathrm{CH}), 7.20\left(\mathrm{~d},{ }^{3} \mathrm{~J}_{\mathrm{HH}}=7.1 \mathrm{~Hz}, 1 \mathrm{H}, 5\right.$ - or 8-dihydronaphthyl $\left.\mathrm{CH}\right), 7.28(\mathrm{~m}, 2 \mathrm{H}, \mathrm{o}$-aryl $\mathrm{CH})$. $\left\{{ }^{1} \mathrm{H}\right\}^{13} \mathrm{C}$ NMR $\left(126 \mathrm{MHz}, \mathrm{CDCl}_{3}, 23^{\circ} \mathrm{C}\right): \delta 23.70,28.54,55.50,113.80,125.60,126.37$, $127.09,127.14,127.71,130.00,133.39,135.49,137.06,139.49,158.97 .{ }^{1} \mathrm{H}$ and ${ }^{13} \mathrm{C}$ NMR spectra are consistent with previously reported data. ${ }^{10}$

1-isopropyl-6-methoxy-3,4-dihydronaphthalene (5a). Following a
modified literature procedure, ${ }^{11}$ a $250 \mathrm{~mL}$ oven-dried schlenk flask was charged with a magnetic stir bar, $9.75 \mathrm{~mL}$ (19.5 mmol, $2 \mathrm{M}$ in tetrahydrofuran) $\mathrm{PrMgCl}$, and $0.48 \mathrm{~g} \mathrm{(1.5} \mathrm{mmol)} \mathrm{Znl}_{2}$ under an inert atmosphere. The reaction flask was stirred for 1 hour and cooled to $0 \stackrel{\circ}{\circ}$. To the reaction flask was added $2.64 \mathrm{~g}(15 \mathrm{mmol})$ of 6 methoxy-1-tetralone in portions. Following the addition, the reaction flask was allowed to warm to room temperature and stirred for 10 hours. The vessel was cooled to $0{ }^{\circ} \mathrm{C}$ and aqueous ammonium chloride $(10 \mathrm{~mL})$ was slowly added via syringe to quench the reaction. An additional $100 \mathrm{~mL}$ of water were then added. The reaction mixture was extracted with ethyl acetate $(2 \times 50 \mathrm{~mL})$. The organic layers were combined and washed with $100 \mathrm{~mL}$ of brine and dried with sodium sulfate. Following solvent removal, the crude 
alcohol was dissolved in $50 \mathrm{~mL}$ toluene and $0.150 \mathrm{~g}$ p-toluenesulfonic acid $(0.79 \mathrm{mmol})$ was added. The reaction was heated to reflux for 2 hours with removal of water with a Dean-Stark apparatus. Following solvent evaporation, the residue was dissolved in 50 $\mathrm{mL}$ ethyl acetate and extracted with $50 \mathrm{~mL}$ concentrated aqueous $\mathrm{NaHCO}_{3}$, washed with $25 \mathrm{~mL}$ brine and dried over sodium sulfate. Following solvent evaporation, the crude alkene was purified via column chromatography using hexane as the eluent to afford $1.157 \mathrm{~g} \mathrm{(5.7} \mathrm{mmol)} \mathrm{of} \mathrm{1-isopropyl-6-methoxy-3,4-dihydronaphthalene} \mathrm{(5a)} \mathrm{as} \mathrm{a} \mathrm{clear} \mathrm{oil.}$ The alkene can subsequently be crystallized from a concentrated pentane solution at -35 으. ${ }^{1} \mathrm{H}$ NMR (500 MHz, $\left.\mathrm{C}_{6} \mathrm{D}_{6}, 23 \stackrel{\circ}{\circ} \mathrm{C}\right): \delta 1.16\left(\mathrm{~d},{ }^{3} \mathrm{JHH}_{\mathrm{HH}}=6.8 \mathrm{~Hz}, 6 \mathrm{H}, \mathrm{iPr}-\mathrm{CH}_{3}\right), 2.07(\mathrm{~m}, 2 \mathrm{H}$, allylic $\left.\mathrm{CH}_{2}\right), 2.55\left(\mathrm{t},{ }^{3} \mathrm{JHH}_{\mathrm{H}}=7.7 \mathrm{~Hz}\right.$, benzylic $\left.\mathrm{CH}_{2}\right), 2.84\left(\mathrm{sep},{ }^{3} \mathrm{~J}_{\mathrm{HH}}=6.6 \mathrm{~Hz}, \mathrm{iPr}-\mathrm{CH}\right), 3.38$ (s, $3 \mathrm{H}, \mathrm{OCH}_{3}$ ), $5.68\left(\mathrm{t},{ }^{3} \mathrm{JHH}_{\mathrm{H}}=4.5 \mathrm{~Hz}, 1 \mathrm{H}\right.$, alkenyl $\mathrm{CH}$ ), 6.72-6.78 (overlapping m, 2H, 5and 7-dihydronaphthyl $\mathrm{CH}), 7.19\left(\mathrm{~d},{ }^{3} \mathrm{~J}_{\mathrm{HH}}=8.4 \mathrm{~Hz}, 8\right.$ - dihydronaphthyl $\left.\mathrm{CH}\right) .{ }^{1} \mathrm{H}$ NMR $\left(500 \mathrm{MHz}, \mathrm{CDCl}_{3}, 2{ }^{\circ}{ }^{\circ} \mathrm{C}\right): \delta 1.14\left(\mathrm{~d},{ }^{3} \mathrm{~J}_{\mathrm{HH}}=6.8 \mathrm{~Hz}, 6 \mathrm{H}, \mathrm{iPr}-\mathrm{CH}_{3}\right), 2.18-2.26(\mathrm{~m}, 2 \mathrm{H}$, allylic $\left.\mathrm{CH}_{2}\right), 2.68\left(\mathrm{~m}, 2 \mathrm{H}\right.$, benzylic $\left.\mathrm{CH}_{2}\right), 2.89\left(\mathrm{sep},{ }^{3} \mathrm{JHH}_{\mathrm{HH}}=6.7 \mathrm{~Hz}, 1 \mathrm{H}, \mathrm{iPr}-\mathrm{CH}\right), 3.81(\mathrm{~s}, 3 \mathrm{H}$, $\mathrm{OCH}_{3}$ ), $5.75\left(\mathrm{dt},{ }^{3} \mathrm{JHH}_{\mathrm{HH}}=4.6 \mathrm{~Hz},{ }^{4} \mathrm{~J}_{\mathrm{HH}}=1.2 \mathrm{~Hz}, 1 \mathrm{H}\right.$, alkenyl $\mathrm{CH}$ ), 6.71-6.76 (overlapping m, $2 \mathrm{H}, 5$ - and 7-dihydronaphthyl $\mathrm{CH}), 7.21-7.25(\mathrm{~m}, 1 \mathrm{H}, 8-$ dihydronaphthyl $\mathrm{CH}) \cdot\left\{{ }^{1} \mathrm{H}{ }^{13} \mathrm{C}\right.$ NMR (126 MHz, $\left.\mathrm{CDCl}_{3}, 23{ }^{\circ} \mathrm{C}\right): \delta 22.47,23.21,28.53,29.30,55.43,110.99,113.94$, $119.41,123.83,128.35,139.17,142.43,158.18 .{ }^{1} \mathrm{H}$ and ${ }^{13} \mathrm{C}$ NMR spectra are consistent with previously reported data. Error! Bookmark not defined.

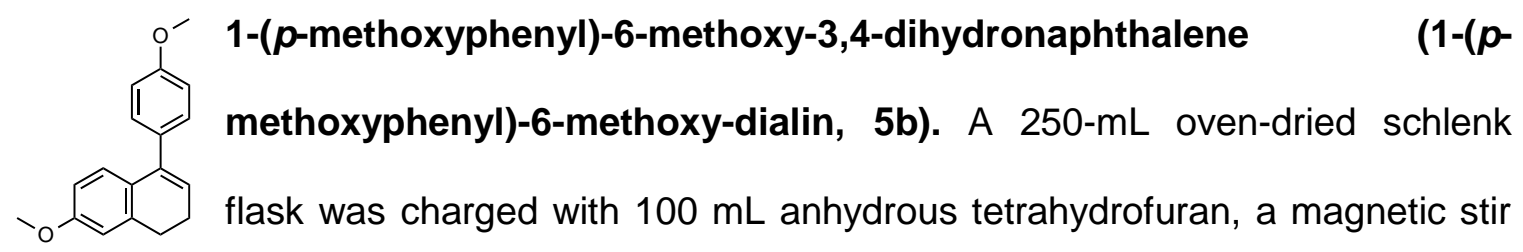
bar and $25 \mathrm{~mL}$ of $\mathrm{p}$-methoxyphenylmagnesium bromide $(0.5 \mathrm{M}$ in tetrahydrofuran, 12.5 $\mathrm{mmol})$ via cannula transfer. The reaction vessel was cooled to $-78{ }^{\circ} \mathrm{C}$ and $1.863 \mathrm{~g}(10.4$ mmol) 6-methoxy-1-tetralone was added in portions. The reaction vessel was allowed to warm to room temperature and stirred for an additional 6 hours at room temperature. 
The vessel was cooled to $0{ }^{\circ} \mathrm{C}$ and aqueous ammonium chloride $(10 \mathrm{~mL})$ was slowly added via syringe to quench the reaction. An additional $100 \mathrm{~mL}$ of water were then added upon complete consumption of the Grignard reagent. The reaction mixture was extracted with ethyl acetate $(2 \times 50 \mathrm{~mL})$. The organic layers were combined and washed with $100 \mathrm{~mL}$ of brine and dried with sodium sulfate. Following solvent removal, the crude alcohol was dissolved in toluene and $0.150 \mathrm{~g} p$-toluenesulfonic acid $(0.79 \mathrm{mmol})$ was added. The reaction was heated to reflux for 6 hours with removal of water with a DeanStark apparatus. Following cooling and solvent evaporation, the residue was dissolved in $150 \mathrm{~mL}$ ethyl acetate and extracted with conc. aqueous $\mathrm{NaHCO}_{3}(100 \mathrm{~mL})$ and brine. The organics were dried over sodium sulfate and filtered and the solvent was removed. The crude product was purified via column chromatography to afford $2.10 \mathrm{~g}(7.87 \mathrm{mmol}$, $76 \%$ yield) of 1-(p-methoxyphenyl)-6-methoxy-3,4-dihydronaphthalene, $\mathbf{5 b}$, as a white solid. The solid can be further purified through recrystallization from a concentrated hexane solution or a concentrated tetrahydrofuran solution stored at $-35 \stackrel{\circ}{\circ} \mathrm{C} .{ }^{1} \mathrm{H}$ NMR $\left(500 \mathrm{MHz}, \mathrm{CDCl}_{3}, 23^{\circ} \mathrm{C}\right): \delta 2.37\left(\mathrm{~m}, 2 \mathrm{H}, 3\right.$-dihydronaphthyl $\left.\mathrm{CH}_{2}\right), 2.82\left(\mathrm{t},{ }^{3} \mathrm{~J}_{\mathrm{HH}}=7.9 \mathrm{~Hz}\right.$, $2 \mathrm{H}$, 4-dihydronaphthyl $\mathrm{CH}_{2}$ ), 3.81 (s, 3H, p-aryl $\mathrm{OCH}_{3}$ ), 3.84 (s, 3H, 6-dihydronaphthyl $\left.\mathrm{OCH}_{3}\right), 5.91\left(\mathrm{t},{ }^{3} \mathrm{JHH}_{\mathrm{HH}}=4.7 \mathrm{~Hz}, 1 \mathrm{H}\right.$, 2-dihydronaphthyl $\left.\mathrm{CH}\right), 6.64\left(\mathrm{dd},{ }^{3} \mathrm{JHH}_{\mathrm{HH}}=8.5 \mathrm{~Hz},{ }^{4} \mathrm{JHH}_{\mathrm{HH}}=\right.$ 2.7 Hz, $1 \mathrm{H}, 7$-dihydronaphthyl $\mathrm{CH}), 6.77\left(\mathrm{~d},{ }^{4} \mathrm{~J}_{\mathrm{HH}}=2.7 \mathrm{~Hz}, 1 \mathrm{H}, 5\right.$-dihydronaphthyl $\mathrm{CH}$ ), 6.89-6.93 (m, 2H, o-aryl CH), $6.95\left(\mathrm{~d},{ }^{3} \mathrm{~J}_{\mathrm{HH}}=8.5 \mathrm{~Hz}, 1 \mathrm{H}, 8\right.$-dihydronaphthyl $\left.\mathrm{CH}\right), 7.25-$ $7.29(\mathrm{~m}, 2 \mathrm{H}, \mathrm{m}$-aryl CH$) \cdot\left\{{ }^{1} \mathrm{H}\right\}^{13} \mathrm{C}$ NMR $\left(126 \mathrm{MHz}, \mathrm{CDCl}_{3}, 23{ }^{\circ} \mathrm{C}\right): \delta .23 .67$ (3dihydronaphthyl $\left.\mathrm{CH}_{2}\right), 29.07$ (4-dihydronaphthyl $\left.\mathrm{CH}_{2}\right), 55.47\left(\mathrm{OCH}_{3}\right), 55.51\left(\mathrm{OCH}_{3}\right)$, 110.85 (7-dihydronaphthyl $\mathrm{CH}$ ), 113.76 (o-aryl $\mathrm{CH}$ ), 113.92 (5-dihydronaphthyl $\mathrm{CH}$ ), 124.63 (2-dihydronaphthyl $\quad \mathrm{CH}), \quad 126.79 \quad$ (8-dihydronaphthyl $\quad \mathrm{CH}), \quad 128.64 \quad$ (1dihydronaphthyl $\quad C), \quad 129.93$ (m-aryl $\quad C H), 133.61 \quad$ (ipso-aryl $\quad C), 138.92 \quad$ (8adihydronaphthyl C), 139.05 (4a-dihydronaphthyl $C$ ), 158.67 (6-dihydronaphthyl $\mathrm{COCH}_{3}$ ), 
158.92 (p-aryl $C$ ). ${ }^{1} \mathrm{H}$ and ${ }^{13} \mathrm{C}$ NMR spectra are consistent with previously reported data. $^{12}$

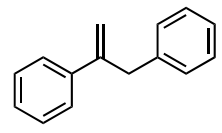

2,3-diphenyl-propene ( $\alpha$-benzyl-styrene, 7a). A $250 \mathrm{~mL}$ oven-dried schlenk flask was charged with a magnetic stir bar, $100 \mathrm{~mL}$ tetrahydrofuran and assembled on a schlenk line under inert atmosphere. To the flask was added $21.84 \mathrm{~g}(61.1 \mathrm{mmol})$ methyltriphenylphosphonium bromide. The flask was cooled to $0 \stackrel{\circ}{\circ} \mathrm{C}$ and $6.86 \mathrm{~g}(61.1 \mathrm{mmol})$ of potassium tert-butoxide was added, resulting in the formation of an orange suspension. Following stirring for 10 minutes, $10.0 \mathrm{~g}(51.0$ $\mathrm{mmol}$ ) of 2-phenylacetophenone was added followed by warming to room temperature and stirring for 2 hours. Following hydrolysis with slow addition of $10 \mathrm{~mL}$ of concentrated aqueous ammonium chloride and dilution with $100 \mathrm{~mL}$ water, the reaction was extracted with diethyl ether $(2 \times 50 \mathrm{~mL})$. The organic layers were combined and washed with 50 $\mathrm{mL}$ brine and dried over magnesium sulfate. Following solvent evaporation, the crude product was purified via column chromatography using hexane as the eluent $\left(R_{f}=0.53\right)$, affording $3.385 \mathrm{~g}$ (17.4 mmol, 34\% yield) of 2,3-diphenylpropene (7a) as a clear oil. ${ }^{1} \mathrm{H}$ NMR (500 MHz, $\mathrm{CDCl}_{3}, 23 \stackrel{\circ}{\circ}$ ): $\delta 3.88\left(\mathrm{~s}, 2 \mathrm{H}\right.$, methylene $\mathrm{CH}_{2}$ ), 5.06 (apparent q, $\mathrm{J}_{\mathrm{HH}}=$ $1.0 \mathrm{~Hz}, 1 \mathrm{H}$, alkenyl $\mathrm{CH}), 5.54(\mathrm{~s}, 1 \mathrm{H}$, alkenyl $\mathrm{CH}), 7.20-7.24(\mathrm{~m}, 1 \mathrm{H}$, phenyl $\mathrm{CH}), 7.25-$ 7.30 (overlapping $\mathrm{m}, 4 \mathrm{H}$, phenyl $\mathrm{CH}$ ), 7.30-7.35 (overlapping $\mathrm{m}, 3 \mathrm{H}$, phenyl $\mathrm{CH}$ ), 7.46$7.49(\mathrm{~m}, 2 \mathrm{H}$, phenyl $\mathrm{CH}) \cdot\left\{{ }^{1} \mathrm{H}\right\}^{13} \mathrm{C}$ NMR $\left(126 \mathrm{MHz}, \mathrm{CDCl}_{3}, 23{ }^{\circ} \mathrm{C}\right): \delta 41.80,114.48$, 126.29, 126.32, $127.65,128.45,128.54,129.13,139.70,140.97,147.08 .{ }^{1} \mathrm{H}$ and ${ }^{13} \mathrm{C}$ NMR spectra are consistent with previously reported data. ${ }^{13}$

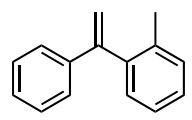

1-(o-tolyl)-1-phenyl-ethylene (9a). A $250 \mathrm{~mL}$ oven-dried schlenk flask was charged with a magnetic stir bar, $100 \mathrm{~mL}$ tetrahydrofuran and assembled on a schlenk line under inert atmosphere. To the flask was added $10.16 \mathrm{~g}(25.1 \mathrm{mmol})$ methyltriphenylphosphonium iodide. The flask was cooled to $0 \stackrel{\circ}{\circ} \mathrm{C}$ and $16.67 \mathrm{~mL}$ (26.8 $\mathrm{mmol}, 1.6 \mathrm{M}$ in hexane) of $n$-butyllithium was added, resulting in the formation of a red 
solution. Following stirring for 20 minutes, $3.29 \mathrm{~g} \quad(16.67 \mathrm{mmol})$ of 2 methylbenzophenone was added followed by warming to room temperature and stirring for 12 hours. Following hydrolysis with slow addition of $10 \mathrm{~mL}$ of concentrated aqueous ammonium chloride and dilution with $100 \mathrm{~mL}$ water, the reaction was extracted with diethyl ether $(2 \times 50 \mathrm{~mL})$. The organic layers were combined and washed with $50 \mathrm{~mL}$ brine and dried over magnesium sulfate. Following solvent evaporation, the crude product was purified via column chromatography using hexane as the eluent $\left(R_{f}=0.76\right)$, affording $1.72 \mathrm{~g}$ (8.85 mmol, 53\% yield) of 1-(o-tolyl)-1-phenyl-ethylene (9a) as a clear oil. ${ }^{1} \mathrm{H}$ NMR (500 MHz, $\left.\mathrm{CDCl}_{3}, 23{ }^{\circ} \mathrm{C}\right): \delta 2.06\left(\mathrm{~d},{ }^{4} J_{\mathrm{HH}}=0.6 \mathrm{~Hz}, 3 \mathrm{H}, \mathrm{CH}_{3}\right), 5.20\left(\mathrm{~d},{ }^{2} J_{\mathrm{HH}}=\right.$ $1.5 \mathrm{~Hz}, 1 \mathrm{H}$, alkenyl $\mathrm{CH}$ ), $5.77\left(\mathrm{~d},{ }^{2} J_{\mathrm{HH}}=1.5 \mathrm{~Hz}, 1 \mathrm{H}\right.$, alkenyl $\mathrm{CH}$ ), 7.17-7.30 (overlapping $\mathrm{m}, 10 \mathrm{H}$, aryl $\mathrm{CH}) \cdot\left\{{ }^{1} \mathrm{H}{ }^{13} \mathrm{C}\right.$ NMR (126 MHz, $\mathrm{CDCl}_{3}, 23{ }^{\circ} \mathrm{C}$ ): $\delta 20.33\left(\mathrm{CH}_{3}\right), 115.08$ (alkenyl $\mathrm{CH}_{2}$ ), 125.87 (p-phenyl $\mathrm{CH}$ ), 126.67 (2C, phenyl $\mathrm{CH}$ ), 127.72 (tolyl $\mathrm{CH}$ ), 127.76 (tolyl $\mathrm{CH}$ ), 128.53 (2C, phenyl $\mathrm{CH}$ ), 130.22 (tolyl $\mathrm{CH}$ ), 130.26 (tolyl $\mathrm{CH}$ ), 136.34 (o-tolyl $\mathrm{C}$ ), 140.77 (ipso-tolyl C), 141.82 (ipso-phenyl C), 149.63 (alkenyl C). ${ }^{1} \mathrm{H}$ and ${ }^{13} \mathrm{C}$ NMR spectra are consistent with previously reported data. ${ }^{14}$

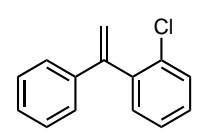

1-(o-chloro)-1-phenyl-ethylene (9b). A $250 \mathrm{~mL}$ oven-dried schlenk flask was charged with a magnetic stir bar, $100 \mathrm{~mL}$ tetrahydrofuran and assembled on a schlenk line under inert atmosphere. To the flask was added $1.237 \mathrm{~g} \mathrm{(8}$ mmol) 2'-chloroacetophenone and the flask was then cooled to $-78{ }^{\circ} \mathrm{C}$. To the flask was added $8 \mathrm{~mL}$ of phenylmagnesium bromide ( $8 \mathrm{mmol}, 1 \mathrm{M}$ in 2-methyl-tetrahydrofuran) via cannula transfer. After stirring for 30 minutes, the reaction vessel was allowed to warm to room temperature and stirred for another 30 minutes. Following hydrolysis of the reaction by the slow addition of water $(100 \mathrm{~mL})$, the reaction mixture was extracted with ethyl acetate $(2 \times 50 \mathrm{~mL})$. The organic fractions were combined and washed with brine $(50 \mathrm{~mL})$ and dried over sodium sulfate. Following filtration and solvent evaporation, the crude alcohol was dissolved in $100 \mathrm{~mL}$ of benzene and transferred to a $250 \mathrm{~mL}$ round 
bottom flask. To the flask was added $0.15 \mathrm{~g} p$-toluenesulfonic acid $(0.08 \mathrm{mmol})$. The reaction was heated to reflux for 2 hours with removal of water with a Dean-Stark apparatus. Following cooling and solvent evaporation, the residue was dissolved in 150 $\mathrm{mL}$ ethyl acetate and extracted with conc. aqueous $\mathrm{NaHCO}_{3}(100 \mathrm{~mL})$ and brine. The organic layer was washed with $50 \mathrm{~mL}$ brine and dried over sodium sulfate. Following filtration, the filtrate was concentrated and the crude alkene product was purified via column chromatography using hexane as the eluent $\left(R_{f}=0.52\right)$ to obtain $0.733 \mathrm{~g}(3.41$ mmol, $43 \%$ yield) of $\mathbf{1}$-(o-chloro)-1-phenyl-ethylene (9b) as a clear oil. ${ }^{1} \mathrm{H}$ NMR (500 $\left.\mathrm{MHz}, \mathrm{CDCl}_{3}, 23 \stackrel{\circ}{\circ} \mathrm{C}\right): \delta 5.30\left(\mathrm{~d},{ }^{2} \mathrm{~J}_{\mathrm{HH}}=1.0 \mathrm{~Hz}, 1 \mathrm{H}\right.$, alkenyl $\left.\mathrm{CH}\right), 5.84\left(\mathrm{~d},{ }^{2} \mathrm{~J}_{\mathrm{HH}}=1.0 \mathrm{~Hz}\right.$, $1 \mathrm{H}$, alkenyl $\mathrm{CH}$ ), 7.26-7.36 (overlapping $\mathrm{m}, 8 \mathrm{H}$, aryl, phenyl $\mathrm{CH}$ ), 7.38-7.43 $(\mathrm{m}, 1 \mathrm{H}$, aryl $\mathrm{CH}$. $\left\{{ }^{1} \mathrm{H}\right\}^{13} \mathrm{C}$ NMR (126 MHz, $\mathrm{CDCl}_{3}, 23^{\circ} \mathrm{C}$ ): $\delta 116.46$ (alkenyl $\mathrm{CH}$ ), 126.62 (phenyl $\mathrm{CH}$ ), 126.89 (phenyl $\mathrm{CH}$ ), 127.95 (aryl $\mathrm{CH}$ ), 128.53 (phenyl $\mathrm{CH}$ ), 129.07 (aryl $\mathrm{CH}$ ), 129.92 (aryl $\mathrm{CH}$ ), 131.81 (aryl $\mathrm{CH}$ ), 133.49 (ipso 2-aryl CCl), 139.96 (ipso aryl C), 140.89 (ipso phenyl C), 147.66 (alkenyl C). HR-MS (+El): Calc'd for: $\mathrm{C}_{14} \mathrm{H}_{11} \mathrm{Cl}$, [M] ${ }^{++}, \mathrm{m} / \mathrm{z} 214.05493$. Found $m / z 214.0551$.

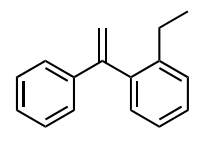

1-(o-ethyl)-1-phenyl-ethylene (9c). A $250 \mathrm{~mL}$ oven-dried schlenk flask was charged with a magnetic stir bar, $100 \mathrm{~mL}$ tetrahydrofuran and assembled on

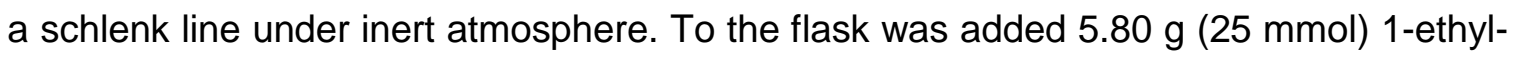
2-iodobenzene and the flask was then cooled to $-78{ }^{\circ} \mathrm{C}$. To the flask was added $10 \mathrm{~mL}$ of $n$-butyllithium bromide (25 mmol, $2.5 \mathrm{M}$ in hexane) via cannula transfer. After stirring for 30 seconds, $3.00 \mathrm{~g}(25 \mathrm{mmol})$ acetophenone was added dropwise. The reaction vessel was allowed to stir for 30 minutes then was warmed to room temperature and stirred for another 30 minutes. Following hydrolysis of the reaction by the slow addition of water $(100 \mathrm{~mL})$, the reaction mixture was extracted with ethyl acetate $(2 \times 50 \mathrm{~mL})$. The organic fractions were combined and washed with brine $(50 \mathrm{~mL})$ and dried over sodium sulfate. Following filtration and solvent evaporation, the crude alcohol was dissolved in 
$100 \mathrm{~mL}$ of benzene and transferred to a $250 \mathrm{~mL}$ round bottom flask. To the flask was added $0.15 \mathrm{~g} p$-toluenesulfonic acid $(0.08 \mathrm{mmol})$. The reaction was heated to reflux for 2 hours with removal of water with a Dean-Stark apparatus. Following cooling and solvent evaporation, the residue was dissolved in $150 \mathrm{~mL}$ ethyl acetate and extracted with conc. aqueous $\mathrm{NaHCO}_{3}(100 \mathrm{~mL})$ and brine. The organic layer was washed with $50 \mathrm{~mL}$ brine and dried over sodium sulfate. Following filtration, the filtrate was concentrated and the crude alkene product was purified via column chromatography using hexane as the eluent $\left(R_{f}=0.42\right)$ to obtain $1.818 \mathrm{~g}(8.73 \mathrm{mmol}, 35 \%$ yield) of 1-(o-ethyl)-1-phenylethylene (9c) as a clear oil. A byproduct, 1-n-butyl-2-ethylbenzene, eluted from the column first and could also be isolated. ${ }^{1} \mathrm{H} \mathrm{NMR}\left(500 \mathrm{MHz}, \mathrm{CDCl}_{3}, 23 \stackrel{\circ}{\circ} \mathrm{C}\right): \delta 1.04\left(\mathrm{t},{ }^{3} \mathrm{~J}_{\mathrm{HH}}\right.$ $=7.6 \mathrm{~Hz}, 3 \mathrm{H}$, ethyl $\left.\mathrm{CH}_{3}\right), 2.42\left(\mathrm{q},{ }^{3} \mathrm{~J}_{\mathrm{HH}}=7.6 \mathrm{~Hz}, 2 \mathrm{H}\right.$, ethyl $\left.\mathrm{CH}_{2}\right), 5.21\left(\mathrm{~d},{ }^{2} \mathrm{~J}_{\mathrm{HH}}=1.5 \mathrm{~Hz}\right.$, $1 \mathrm{H}$, alkenyl $\mathrm{CH}$ ), $5.79\left(\mathrm{~d},{ }^{2} \mathrm{~J}_{\mathrm{HH}}=1.5 \mathrm{~Hz}, 1 \mathrm{H}\right.$, alkenyl $\mathrm{CH}$ ), 7.19-7.34 (overlapping $\mathrm{m}, 9 \mathrm{H}$, aryl and phenyl $\mathrm{CH}) \cdot\left\{{ }^{1} \mathrm{H}\right\}^{13} \mathrm{C}$ NMR $\left(126 \mathrm{MHz}, \mathrm{CDCl}_{3}, 23{ }^{\circ} \mathrm{C}\right.$ ): $\delta 15.42$ (ethyl $\mathrm{CH}_{3}$ ), 26.48 (ethyl $\mathrm{CH}_{2}$ ), 115.15 (alkenyl $\mathrm{CH}_{2}$ ), $125.78(\mathrm{CH}), 126.68$ (phenyl $\mathrm{CH}$ ), $127.78(\mathrm{CH})$, $127.91(\mathrm{CH}), 128.48$ (phenyl $\mathrm{CH}$ ), 128.62 (aryl $\mathrm{CH}$ ), 130.43 (aryl $\mathrm{CH}$ ), 141.07 (ipso phenyl-C), 141.28 (ipso aryl-C), 142.37 (2-aryl CEt), 149.35 (alkenyl C). HR-MS (+EI): Calc'd for: $\mathrm{C}_{16} \mathrm{H}_{16},[\mathrm{M}]^{++}, m / z$ 208.12520. Found $m / z$ 208.1249.

1-(o-methoxy)-1-phenyl-ethylene (9d). A $250 \mathrm{~mL}$ oven-dried schlenk assembled on a schlenk line under inert atmosphere. To the flask was added $3.75 \mathrm{~g}$ (25 mmol) 2'-methoxyacetophenone and the flask was then cooled to $-78 \stackrel{\circ}{\circ} \mathrm{C}$. To the flask was added $25 \mathrm{~mL}$ of phenylmagnesium bromide $(25 \mathrm{mmol}, 1 \mathrm{M}$ in 2-methyltetrahydrofuran) via cannula transfer. After stirring for 15 minutes, the reaction vessel was allowed to warm to room temperature and stirred for another 30 minutes. Following hydrolysis of the reaction by the slow addition of water $(100 \mathrm{~mL})$, the reaction mixture was extracted with ethyl acetate $(2 \times 50 \mathrm{~mL})$. The organic fractions were combined and 
washed with brine $(50 \mathrm{~mL})$ and dried over sodium sulfate. Following filtration and solvent evaporation, the crude alcohol was dissolved in $100 \mathrm{~mL}$ of benzene and transferred to a $250 \mathrm{~mL}$ round bottom flask. To the flask was added $0.15 \mathrm{~g} p$-toluenesulfonic acid $(0.08$ $\mathrm{mmol})$. The reaction was heated to reflux for 2 hours with removal of water with a DeanStark apparatus. Following cooling and solvent evaporation, the residue was dissolved in $150 \mathrm{~mL}$ ethyl acetate and extracted with conc. aqueous $\mathrm{NaHCO}_{3}(100 \mathrm{~mL})$ and brine. The organic layer was washed with $50 \mathrm{~mL}$ brine and dried over sodium sulfate. Following filtration, the filtrate was concentrated and the crude alkene product was purified via column chromatography using $5 \%$ ethyl acetate in hexane as the eluent $\left(R_{f}=\right.$ $0.35)$ to obtain $3.156 \mathrm{~g}(15.0 \mathrm{mmol}, 60 \%$ yield) of 1-(o-methoxy)-1-phenyl-ethylene (9d) as a clear oil. ${ }^{1} \mathrm{H}$ NMR $\left(500 \mathrm{MHz}, \mathrm{CDCl}_{3}, 23{ }^{\circ} \mathrm{C}\right): \delta 3.65\left(\mathrm{~s}, 3 \mathrm{H}, \mathrm{OCH}_{3}\right), 5.33(\mathrm{~s}, 1 \mathrm{H}$, alkenyl $\mathrm{CH}$ ), $5.74(\mathrm{~s}, 1 \mathrm{H}$, alkenyl $\mathrm{CH}), 6.92\left(\mathrm{~d},{ }^{3} \mathrm{~J}_{\mathrm{HH}}=8.2 \mathrm{~Hz}, 1 \mathrm{H}, 3\right.$-aryl $\left.\mathrm{CH}\right), 6.99(\mathrm{~m}$, $1 \mathrm{H}$, aryl $\mathrm{CH}$ ), 7.22-7.32 (overlapping $\mathrm{m}, 6 \mathrm{H}$, phenyl and aryl $\mathrm{CH}), 7.32-7.36(\mathrm{~m}, 1 \mathrm{H}, 4-$ aryl $\mathrm{CH}) .\left\{{ }^{1} \mathrm{H}\right\}^{13} \mathrm{C}$ NMR (126 MHz, $\left.\mathrm{CDCl}_{3}, 23^{\circ} \mathrm{C}\right): \delta 55.82\left(\mathrm{OCH}_{3}\right), 111.41$ (aryl $\left.\mathrm{CH}\right)$, 115.60 (alkenyl $\mathrm{CH}_{2}$ ), 120.80 (aryl $\mathrm{CH}$ ), 126.55 (phenyl $\mathrm{CH}$ ), 127.49 (aryl $\mathrm{CH}$ ), 128.22 (phenyl $\mathrm{CH}$ ), 129.19 (phenyl $\mathrm{CH}$ ), 131.28 (ipso aryl C), 131.46 (aryl $\mathrm{CH}$ ), 141.22 (alkenyl C), 147.17 (ipso phenyl-C), 158.07 (2-aryl $C O \mathrm{CH}_{3}$ ). HR-MS (+El): Calc'd for: $\mathrm{C}_{15} \mathrm{H}_{14} \mathrm{O}$, $[\mathrm{M}]^{\bullet+}, m / z 210.10447$. Found $m / z 210.1040$.

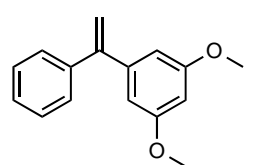

1-phenyl-1-(m,m-dimethoxyphenyl)-ethylene (11). Substrate 18 was prepared according to a literature procedure and ${ }^{1} \mathrm{H}$ and ${ }^{13} \mathrm{C}$ NMR spectra are consistent with previously reported data. ${ }^{15}{ }^{1} \mathrm{H} N M R\left(500 \mathrm{MHz} \mathrm{CDCl}_{3}, 23\right.$ $\left.{ }^{\circ} \mathrm{C}\right): \delta 3.77\left(\mathrm{~s}, 6 \mathrm{H}, \mathrm{OCH}_{3}\right.$ ), 5.46 (overlapping s, $2 \mathrm{H}$, alkenyl- $\left.\mathrm{CH}\right), 6.44\left(\mathrm{t},{ }^{4} \mathrm{~J}_{\mathrm{HH}}=2.3 \mathrm{~Hz}\right.$, $1 \mathrm{H}, p$-aryl-CH), $6.49\left(\mathrm{~d},{ }^{4} \mathrm{~J}_{\mathrm{HH}}=2.3 \mathrm{~Hz}, 2 \mathrm{H}\right.$, o-aryl-CH), 7.29-7.37 (overlapping $\mathrm{m}, 5 \mathrm{H}$, phenyl-CH). $\left\{{ }^{1} \mathrm{H}\right\}^{13} \mathrm{C}$ NMR (126 MHz, $\left.\mathrm{CDCl}_{3}, 2{ }^{\circ} \mathrm{C}\right): \delta 55.58,100.00,106.82,114.65$, 127.95, 128.34, 128.42, 141.34, 143.87, 150.17, 160.70. 


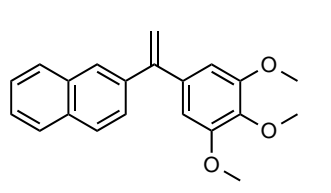
1-(2'-naphthyl)-1-(m,m,p-trimethoxyphenyl)-ethylene

(13). A 100-mL oven-dried schlenk flask was charged with $20 \mathrm{~mL}$ anhydrous diethyl ether, a magnetic stir bar and $0.788 \mathrm{~g}(3.8 \mathrm{mmol})$ 2-bromonaphthalene. The reaction vessel was cooled to $-78{ }^{\circ} \mathrm{C}$ and $1.52 \mathrm{~mL}$ of $n$ butyllithium (3.81 mmol, $2.5 \mathrm{M}$ in hexane) was added dropwise via cannula transfer. Then, $0.800 \mathrm{~g}(3.81 \mathrm{mmol})$ of $3^{\prime}, 4^{\prime}, 5^{\prime}$-trimethoxyacetophenone was added in portions. The reaction vessel was stirred at $-78 \stackrel{\circ}{ } \mathrm{C}$ for 20 minutes, then allowed to warm to room temperature for 3 hours. The vessel was cooled to $0{ }^{\circ} \mathrm{C}$ and aqueous ammonium chloride $(10 \mathrm{~mL})$ was slowly added via syringe to quench the reaction. An additional 50 $\mathrm{mL}$ of water were then added. The reaction mixture was extracted with ethyl acetate $(2 \mathrm{x}$ $50 \mathrm{~mL}$ ). The organic layers were combined and washed with $100 \mathrm{~mL}$ of brine and dried with sodium sulfate. Following solvent removal, the crude alcohol was dissolved in 30 $\mathrm{mL}$ dichloromethane and $0.075 \mathrm{~g}$-toluenesulfonic acid $(0.39 \mathrm{mmol})$ was added. The reaction flask was stirred for 4 hours at room temperature. The reaction mixture was then diluted with $50 \mathrm{~mL}$ dichloromethane and extracted with concentrated aqueous $\mathrm{NaHCO}_{3}$. The organic layer was washed with $50 \mathrm{~mL}$ brine and dried over sodium sulfate. Following solvent evaporation, the crude product was purified via column chromatography, affording $0.679 \mathrm{~g}(2.12 \mathrm{mmol}, 56 \%$ yield $)$ of 1-(2'-naphthyl)-1-(m,m,ptrimethoxyphenyl)-ethylene (13) as a white solid. ${ }^{1} \mathrm{H} \mathrm{NMR}\left(500 \mathrm{MHz}, \mathrm{CDCl}_{3}, 23{ }^{\circ} \mathrm{C}\right): \delta$ $3.80\left(\mathrm{~s}, 6 \mathrm{H}, m-\mathrm{OCH}_{3}\right), 3.90\left(\mathrm{~s}, 3 \mathrm{H}, p-\mathrm{OCH}_{3}\right), 5.52(\mathrm{~s}, 1 \mathrm{H}$, alkenyl $\mathrm{CH}), 5.57(\mathrm{~s}, 1 \mathrm{H}$, alkenyl $\mathrm{CH}$ ), $6.60(\mathrm{~s}, 2 \mathrm{H}, \mathrm{o}$-aryl $\mathrm{CH}$ ), 7.47-7.52 (overlapping $\mathrm{m}, 3 \mathrm{H}$ naphthyl $\mathrm{CH}$ ), 7.807.87 (overlapping $\mathrm{m}, 3 \mathrm{H}$ naphthyl $\mathrm{CH}$ ). $\left(126 \mathrm{MHz}, \mathrm{CDCl}_{3}, 23^{\circ} \mathrm{C}\right): \delta 56.35,61.16,105.89$, $114.70,126.32,126.42,126.59,127.53,127.80,127.87,128.43,133.23,133.48$, $137.45,138.04,138.85,150.28,153.15 .{ }^{1} \mathrm{H}$ and ${ }^{13} \mathrm{C}$ NMR spectra are consistent with previously reported data. ${ }^{16}$ 
1-exo-methylene-benzosuberane (15a). A $250 \mathrm{~mL}$ oven-dried schlenk flask was charged with a magnetic stir bar, $100 \mathrm{~mL}$ tetrahydrofuran and assembled on a schlenk line under inert atmosphere. To the flask was added $10.0 \mathrm{~g}(28 \mathrm{mmol})$ methyltriphenylphosphonium bromide. The flask was cooled to $0{ }^{\circ} \mathrm{C}$ and $3.15 \mathrm{~g}$ (28 mmol) of potassium tert-butoxide was added, resulting in the formation of an orange suspension. Following stirring for 10 minutes, $3 \mathrm{~g}(18.7 \mathrm{mmol})$ of 1 -benzosuberone was added followed by warming to room temperature and stirring for 2 hours. Following hydrolysis with slow addition of $10 \mathrm{~mL}$ of concentrated aqueous ammonium chloride and dilution with $100 \mathrm{~mL}$ water, the reaction was extracted with diethyl ether ( $2 \times 50 \mathrm{~mL})$. The organic layers were combined and washed with $50 \mathrm{~mL}$ brine and dried over magnesium sulfate. Following solvent evaporation, the crude product was purified via column chromatography using hexane as the eluent. Vacuum distillation (the fraction containing the product distilled with the boiling point of $30^{\circ} \mathrm{C}$ at approximately 40 mtorr using a 45 ${ }^{\circ} \mathrm{C}$ oil bath and the schlenk line vacuum) afforded $1.55 \mathrm{~g}$ (9.8 mmol, $52 \%$ yield) of 1 -exomethylene-benzosuberane (15a) as a clear oil. ${ }^{1} \mathrm{H} \mathrm{NMR}\left(500 \mathrm{MHz}, \mathrm{CDCl}_{3}, 23 \stackrel{\circ}{\circ}\right): \delta 1.74$ (m, 2H, alkyl $\left.\mathrm{CH}_{2}\right), 1.84\left(\mathrm{~m}, 2 \mathrm{H}\right.$, alkyl $\left.\mathrm{CH}_{2}\right), 2.39\left(\mathrm{~m}, 2 \mathrm{H}\right.$, allylic $\left.\mathrm{CH}_{2}\right), 2.77(\mathrm{~m}, 2 \mathrm{H}$, benzylic $\mathrm{CH}_{2}$ ), $4.98\left(\mathrm{~d}, \mathrm{~J}_{\mathrm{HH}}=1.9 \mathrm{~Hz}, 1 \mathrm{H}\right.$, alkenyl $\mathrm{CH}$ ), $5.10(\mathrm{~s}, 1 \mathrm{H}$, alkenyl $\mathrm{CH}$ ), 7.08-7.11 (m, $1 \mathrm{H}$, aryl $\mathrm{CH}$ ), 7.13-7.18 (overlapping $\mathrm{m}, 2 \mathrm{H}$, aryl $\mathrm{CH}), 7.18-7.22(\mathrm{~m}, 1 \mathrm{H}$, aryl $\mathrm{CH}$ ). $\left\{{ }^{1} \mathrm{H}\right\}^{13} \mathrm{C}$ NMR $\left(126 \mathrm{MHz}, \mathrm{CDCl}_{3}, 23^{\circ} \mathrm{C}\right): \delta 27.57,31.75,36.57,36.75,113.93,126.27$, 127.28, 128.35, 129.15, 140.46, 144.39, 153.03. ${ }^{1} \mathrm{H}$ and ${ }^{13} \mathrm{C}$ NMR spectra are consistent with previously reported data. ${ }^{17}$

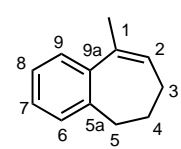

1-methyl-benzosuberene (15b). On a schlenk line, a 250-mL oven-dried schlenk flask was charged with $100 \mathrm{~mL}$ anhydrous diethyl ether, a magnetic stir bar and $25 \mathrm{~mL}$ of methyllithium (1.6 M in diethyl ether, $12.48 \mathrm{mmol}$ ) via cannula transfer. The reaction vessel was stirred and cooled to $-78 \stackrel{\circ}{\circ} \mathrm{C}$ and $2.00 \mathrm{~g}(12.48 \mathrm{mmol})$ 1-benzosuberone was slowly added. The reaction was allowed to warm to room 
temperature and stirred at that temperature for 1 hour. The vessel was cooled to $0{ }^{\circ} \mathrm{C}$ and slowly hydrolyzed with aqueous ammonium chloride (10 mL). An additional $100 \mathrm{~mL}$ of water was then added upon complete consumption of the organolithium reagent. The reaction mixture was extracted with diethyl ether $(2 \times 30 \mathrm{~mL})$. The organic layers were combined and washed with $50 \mathrm{~mL}$ of brine and dried with sodium sulfate. Following solvent removal, the crude alcohol was dissolved in $50 \mathrm{~mL}$ benzene and $0.15 \mathrm{~g} \mathrm{p}$ toluenesulfonic acid $(0.08 \mathrm{mmol})$ was added. The reaction was heated to reflux for 6 hours with removal of water with a Dean-Stark apparatus. Following cooling and solvent evaporation, the residue was dissolved in $150 \mathrm{~mL}$ ethyl acetate and extracted with conc. aqueous $\mathrm{NaHCO}_{3}(100 \mathrm{~mL})$ and brine. The organic layer was washed with $50 \mathrm{~mL}$ brine and dried over sodium sulfate. Following filtration, the filtrate was concentrated and the crude alkene product was purified via column chromatography using hexane as the eluent $\left(R_{f}=0.72\right)$. Vacuum distillation of the alkene (the fraction containing the product came over with the boiling point of $28 \stackrel{\circ}{\mathrm{C}}$ at approximately 80 mtorr using a $45^{\circ} \mathrm{C}$ oil bath and the schlenk line vacuum) afforded $1.04 \mathrm{~g}(6.57 \mathrm{mmol}, 53 \%$ yield $)$ of 1 -methyl-

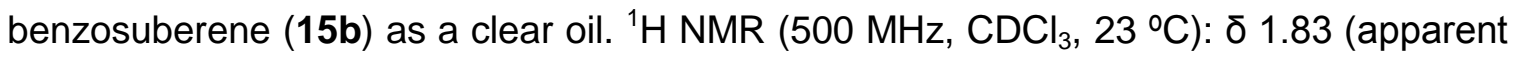
q, ${ }^{3} \mathrm{~J}_{\mathrm{HH}}=7.2 \mathrm{~Hz}, 2 \mathrm{H}, 3$-benzosuberenyl $\left.\mathrm{CH}_{2}\right), 2.90$ (m, 2H, 4-benzosuberenyl $\left.\mathrm{CH}_{2}\right), 2.12$ (s, 3H, CH$\left.H_{3}\right), 2.58\left(\mathrm{t},{ }^{3} \mathrm{~J}_{\mathrm{HH}}=7.0 \mathrm{~Hz}, 2 \mathrm{H}, 5\right.$-benzosuberenyl $\left.\mathrm{CH}_{2}\right), 5.99\left(\mathrm{t},{ }^{3} \mathrm{~J}_{\mathrm{HH}}=7.0 \mathrm{~Hz}\right.$, $1 \mathrm{H}$, 2-benzosuberenyl alkenyl $\mathrm{CH}), 7.15-7.20(\mathrm{~m}, 1 \mathrm{H}$, aryl $\mathrm{CH}), 7.20-7.23(\mathrm{~m}, 1 \mathrm{H}$, aryl $\mathrm{CH})$, 7.24-7.28 $(\mathrm{m}, 1 \mathrm{H}$, aryl $\mathrm{CH}), 7.28-7.31(\mathrm{~m}, 1 \mathrm{H}$, aryl $\mathrm{CH}) \cdot\left\{{ }^{1} \mathrm{H}\right\}^{13} \mathrm{C}$ NMR $(126 \mathrm{MHz}$, $\left.\mathrm{CDCl}_{3}, 23{ }^{\circ} \mathrm{C}\right): \delta 22.87,25.10,32.79,34.76,126.08,126.28,126.65,126.70,128.97$ 137.03, 141.12, 142.11. ${ }^{1} \mathrm{H}$ and ${ }^{13} \mathrm{C}$ NMR spectra are consistent with previously reported data. $^{18}$

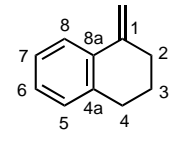

1-exo-methylene-tetralin (17a). A $250 \mathrm{~mL}$ oven-dried schlenk flask was charged with a magnetic stir bar, $100 \mathrm{~mL}$ tetrahydrofuran and assembled on a schlenk line under inert atmosphere. To the flask was added $20.0 \mathrm{~g}$ (56 mmol) 
methyltriphenylphosphonium bromide. The flask was cooled to $0{ }^{\circ} \mathrm{C}$ and $6.28 \mathrm{~g}$ (56 $\mathrm{mmol}$ ) of potassium tert-butoxide was added, resulting in the formation of an orange suspension. Following stirring for 10 minutes, $7.44 \mathrm{~g}(50.9 \mathrm{mmol})$ of 1-tetralone was added followed by warming to room temperature and stirring for 3 hours. Following hydrolysis with slow addition of $10 \mathrm{~mL}$ of concentrated aqueous ammonium chloride and dilution with $100 \mathrm{~mL}$ water, the reaction was extracted with diethyl ether $(2 \times 50 \mathrm{~mL})$. The organic layers were combined and washed with $50 \mathrm{~mL}$ brine and dried over magnesium sulfate. Following solvent evaporation, the crude product was purified via column chromatography using hexane as the eluent. Vacuum distillation (the fraction containing the product came over with the boiling point of $34^{\circ} \mathrm{C}$ at approximately 50 mtorr using the

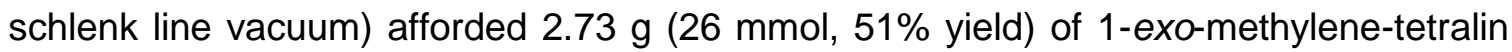
(17a) as a clear oil. ${ }^{1} \mathrm{H} \mathrm{NMR}\left(500 \mathrm{MHz}, \mathrm{CDCl}_{3}, 23 \stackrel{\circ}{\circ} \mathrm{C}\right): \delta 1.89\left(\mathrm{~m}, 2 \mathrm{H}\right.$, 3-tetralinyl $\left.\mathrm{CH}_{2}\right)$, $2.55\left(\mathrm{tt},{ }^{3} \mathrm{~J}_{\mathrm{HH}}=6.2 \mathrm{~Hz},{ }^{4} \mathrm{~J}_{\mathrm{HH}}=1.1 \mathrm{~Hz}, 1 \mathrm{H}, 2\right.$-tetralinyl $\left.\mathrm{CH}_{2}\right), 2.86\left(\mathrm{t},{ }^{3} \mathrm{~J}_{\mathrm{HH}}=6.3 \mathrm{~Hz}, 2 \mathrm{H}, 4\right.$ tetralinyl $\mathrm{CH}_{2}$ ), 4.96 (apparent q, $J_{\mathrm{HH}}=1.4 \mathrm{~Hz}, 1 \mathrm{H}$, alkenyl $\mathrm{CH}$ ), 5.48 (apparent q, $J_{\mathrm{HH}}=$ 1.2, $1 \mathrm{H}$, alkenyl $\mathrm{CH}$ ), 7.09-7.12 (m, 1H, 5-tetralinyl $\mathrm{CH}$ ), 7.13-7.20 (overlapping $\mathrm{m}, 2 \mathrm{H}, 6$ tetralinyl $\mathrm{CH}$, 7-tetralinyl $\mathrm{CH}), 7.64-7.67(\mathrm{~m}, 1 \mathrm{H}, 8$-tetralinyl $\mathrm{CH}) \cdot\left\{{ }^{1} \mathrm{H}\right\}^{13} \mathrm{C} \mathrm{NMR}(126 \mathrm{MHz}$, $\mathrm{CDCl}_{3}, 23^{\circ} \mathrm{C}$ ): $\delta 24.01$ (3-tetralinyl $\mathrm{CH}_{2}$ ), 30.67 (4-tetralinyl $\mathrm{CH}_{2}$ ), 33.45 (2-tetralinyl $\mathrm{CH}_{2}$ ), 108.07 (alkenyl $\mathrm{CH}_{2}$ ) 124.40 (8-tetralinyl $\mathrm{CH}$ ), 126.08 (6- or 7 tetralinyl $\mathrm{CH}$ ), 127.79 (6- or 7 tetralinyl $\mathrm{CH}$ ), 129.41 (5-tetralinyl $\mathrm{CH}$ ), 134.90 (4a- or 8a tetralinyl $\mathrm{C}$ ), 137.52 (4a- or 8a tetralinyl C), 143.65 (1-tetralinyl C). ${ }^{1} \mathrm{H}$ and ${ }^{13} \mathrm{C}$ NMR spectra are consistent with previously reported data. ${ }^{19}$

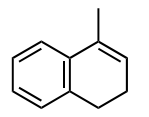

1-methyl-3,4-dihydronaphthalene (17b). On a schlenk line, a 500-mL ovendried schlenk flask was charged with $200 \mathrm{~mL}$ anhydrous diethyl ether, a magnetic stir bar and $25 \mathrm{~mL}$ of methylmagnesium iodide (3 $\mathrm{M}$ in diethyl ether, $75 \mathrm{mmol}$ ). The reaction vessel was stirred and cooled to $-78 \stackrel{\circ}{\circ} \mathrm{C}$ and $9.14 \mathrm{~g}$ (62.5 mmol) 1-tetralone was slowly added. The reaction was allowed to warm to room temperature over 12 
hours. The vessel was cooled to $0 \stackrel{\circ}{ } \mathrm{C}$ and slowly hydrolyzed with aqueous ammonium chloride $(10 \mathrm{~mL})$. An additional $100 \mathrm{~mL}$ of water was then added upon complete consumption of the Grignard reagent. The reaction mixture was extracted with diethyl ether $(2 \times 75 \mathrm{~mL})$. The organic layers were combined and washed with $100 \mathrm{~mL}$ of brine and dried with sodium sulfate. Following solvent removal, the crude alcohol was dissolved in $30 \mathrm{~mL}$ dichloromethane and $0.30 \mathrm{~g}$ p-toluenesulfonic acid $(0.16 \mathrm{mmol})$ was added. The reaction was stirred at room temperature until full consumption of the alcohol was observed by TLC (4 hours). The reaction mixture was then diluted with $50 \mathrm{~mL}$ dichloromethane and extracted with concentrated aqueous $\mathrm{NaHCO}_{3}$. The organic layer was washed with $50 \mathrm{~mL}$ brine and dried over sodium sulfate. Following filtration, the filtrate was concentrated and the crude alkene product was purified via vacuum distillation to afford $7.315 \mathrm{~g}$ (50.7 mmol, $81 \%$ yield) of 1-methyl-3,4-dihydronaphthalene (17b) as a clear oil. ${ }^{1} \mathrm{H} \mathrm{NMR}\left(500 \mathrm{MHz}, \mathrm{CDCl}_{3}, 23{ }^{\circ} \mathrm{C}\right): \delta 2.10$ (apparent q, $\mathrm{JHH}_{\mathrm{HH}}=1.7 \mathrm{~Hz}$, $\left.\mathrm{CH}_{3}\right), 2.30\left(\mathrm{~m}, 2 \mathrm{H}\right.$, allylic $\left.\mathrm{CH}_{2}\right), 2.81\left(\mathrm{t},{ }^{3} \mathrm{JHH}_{\mathrm{HH}}=8.1 \mathrm{~Hz}, 2 \mathrm{H}\right.$, benzylic $\left.\mathrm{CH}_{2}\right), 5.90(\mathrm{~m}, 1 \mathrm{H}$, alkenyl $\mathrm{CH}$ ), 7.15-7.21 (overlapping $\mathrm{m}, 2 \mathrm{H}$, aryl $\mathrm{CH}$ ), 7.23-7.29 (overlapping $\mathrm{m}, 2 \mathrm{H}$, aryl CH). $\left\{{ }^{1} \mathrm{H}\right\}^{13} \mathrm{C}$ NMR (126 MHz, $\left.\mathrm{CDCl}_{3}, 23{ }^{\circ} \mathrm{C}\right): 19.53,23.40,28.56,122.95,125.61$, 126.53, 126.86, 127.54, 132.37, 136.03, 126.50. ${ }^{1} \mathrm{H}$ and ${ }^{13} \mathrm{C}$ NMR spectra are consistent with previously reported data. ${ }^{20}$

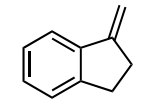

1-exo-methylene-indane (19a). A $250 \mathrm{~mL}$ oven-dried schlenk flask was charged with a magnetic stir bar, $100 \mathrm{~mL}$ diethyl ether, and assembled on a schlenk line under inert atmosphere. To the flask was added $12.82 \mathrm{~g}(25.9 \mathrm{mmol})$ methyltriphenylphosphonium bromide. The flask was cooled to $0{ }^{\circ} \mathrm{C}$ and $20 \mathrm{~mL}(2.5 \mathrm{M}$ in hexane, $50 \mathrm{mmol}$ ) of $n$-butyllithium was added via cannula transfer, resulting in the formation of a red solution. Following stirring for 10 minutes, the reaction flask was cooled to $-78 \stackrel{\circ}{\circ}$ and $3.89 \mathrm{~g}(29.4 \mathrm{mmol})$ of 1 -indanone was added followed by stirring for 20 minutes. The reaction flask was then warmed to room temperature and stirred for 3 
hours. Following hydrolysis with slow addition of $10 \mathrm{~mL}$ of concentrated aqueous ammonium chloride and dilution with $100 \mathrm{~mL}$ water, the reaction was extracted with diethyl ether $(2 \times 50 \mathrm{~mL})$. The organic layers were combined and washed with $50 \mathrm{~mL}$ brine and dried over magnesium sulfate. Following solvent evaporation, the crude product was purified via column chromatography using hexane as the eluent. Vaccum distillation of the product afforded $1.38 \mathrm{~g}(10.6 \mathrm{mmol}, 36 \%$ yield $)$ of 1 -exo-methyleneindane, 19a, as a clear oil. ${ }^{1} \mathrm{H}$ NMR $\left(500 \mathrm{MHz}, \mathrm{CDCl}_{3}, 23 \stackrel{\circ}{\circ} \mathrm{C}\right): \delta 2.86\left(\mathrm{tt},{ }^{3} \mathrm{JHH}_{\mathrm{HH}}=7.0 \mathrm{~Hz}\right.$, ${ }^{4} J_{\mathrm{HH}}=2.3 \mathrm{~Hz}, 2 \mathrm{H}, 2$-indanyl $\mathrm{CH}_{2}$ ), $3.04\left(\mathrm{dd},{ }^{3} \mathrm{~J}_{\mathrm{HH}}=8.3 \mathrm{~Hz},{ }^{3} \mathrm{~J}_{\mathrm{HH}}=5.7 \mathrm{~Hz}, 2 \mathrm{H}, 3\right.$-indanyl $\left.\mathrm{CH}_{2}\right), 5.09\left(\mathrm{t},{ }^{3} \mathrm{JHH}_{\mathrm{HH}}=2.3 \mathrm{~Hz}, 1 \mathrm{H}\right.$, alkenyl $\left.\mathrm{CH}\right), 5.51\left(\mathrm{t},{ }^{3} \mathrm{JHH}_{\mathrm{HH}}=2.6 \mathrm{~Hz}, 1 \mathrm{H}\right.$, alkenyl $\left.\mathrm{CH}\right)$, 7.23-7.29 (overlapping $\mathrm{m}, 2 \mathrm{H}, 5$-indanyl and 6- or 7-indanyl $\mathrm{CH}), 7.30-7.33(\mathrm{~m}, 1 \mathrm{H}, 6$ - or 7-indanyl $\mathrm{CH})$, 7.52-7.58 (m, $1 \mathrm{H}, 4$-indenyl $\mathrm{CH}) \cdot\left\{{ }^{1} \mathrm{H}\right\}^{13} \mathrm{C} \mathrm{NMR}\left(126 \mathrm{MHz}, \mathrm{CDCl}_{3}, 23{ }^{\circ} \mathrm{C}\right)$ : ठ 30.29 (3-indanyl $\mathrm{CH}_{2}$ ), 31.38 (2-indanyl $\mathrm{CH}_{2}$ ), 102.64 (methylene $\mathrm{CH}_{2}$ ), 120.80 (4indanyl $\mathrm{CH}$ ), 125.55 (6-indanyl $\mathrm{CH}$ ), 126.60 (7-indanyl $\mathrm{CH}$ ), 128.44 (5-indanyl $\mathrm{CH}$ ), 141.27 (1-indenyl C), 146.93 (3a-indenyl C), 150.77 (7a-indenyl C). ${ }^{1} \mathrm{H}$ and ${ }^{13} \mathrm{C}$ NMR spectra are consistent with previously reported data. ${ }^{21}$

3-methyl-1H-indene (19b). On a schlenk line, a 250-mL oven-dried schlenk flask was charged with $100 \mathrm{~mL}$ anhydrous diethyl ether, a magnetic stir bar and $10 \mathrm{~mL}$ of methylmagnesium iodide ( $3 \mathrm{M}$ in diethyl ether, $30 \mathrm{mmol})$. The reaction vessel was stirred and cooled to $-78 \stackrel{\circ}{\circ}$ and $3.30 \mathrm{~g}(25.0 \mathrm{mmol}) 1$-indanone was slowly added. The reaction was allowed to warm to room temperature over 12 hours. The vessel was cooled to $0 \stackrel{\circ}{\circ}$ and slowly hydrolyzed with aqueous ammonium chloride $(10 \mathrm{~mL})$. An additional $100 \mathrm{~mL}$ of water was then added upon complete consumption of the Grignard reagent. The reaction mixture was extracted with diethyl ether $(2 \times 50 \mathrm{~mL})$. The organic layers were combined and washed with $100 \mathrm{~mL}$ of brine and dried with sodium sulfate. Following solvent removal, the crude alcohol was dissolved in $25 \mathrm{~mL}$ dichloromethane and $0.15 \mathrm{~g} p$-toluenesulfonic acid $(0.08 \mathrm{mmol})$ was added. The reaction was stirred at 
room temperature until full consumption of the alcohol was observed by TLC (4 hours). The reaction mixture was then diluted with $25 \mathrm{~mL}$ dichloromethane and extracted with concentrated aqueous $\mathrm{NaHCO}_{3}$. The organic layer was washed with $50 \mathrm{~mL}$ brine and dried over sodium sulfate. Following filtration, the filtrate was concentrated and the crude alkene product was purified via column chromatography using hexane as the eluent to

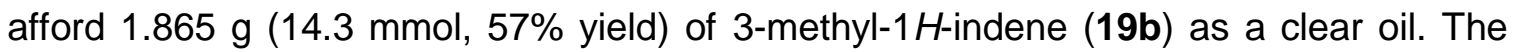
product can further be purified using vacuum distillation. ${ }^{1} \mathrm{H} \mathrm{NMR}\left(500 \mathrm{MHz}, \mathrm{CDCl}_{3}, 23\right.$ $\left.{ }^{\circ} \mathrm{C}\right): \delta 2.17\left(\mathrm{q},{ }^{4} \mathrm{~J}_{\mathrm{HH}}=2.1 \mathrm{~Hz}, 3 \mathrm{H}, \mathrm{CH}_{3}\right.$ ), 3.32 (apparent q, ${ }^{3} J_{\mathrm{HH}}=2.3 \mathrm{~Hz},{ }^{5} J_{\mathrm{HH}}=2.3 \mathrm{~Hz}$, $2 \mathrm{H}$, 1-indenyl $\left.\mathrm{CH}_{2}\right), 6.20(\mathrm{~m}, 1 \mathrm{H}, 2$-indenyl $\mathrm{CH}), 7.20$ (apparent dt, ${ }^{3} \mathrm{~J}_{\mathrm{HH}}=7.3 \mathrm{~Hz},{ }^{4} \mathrm{~J}_{\mathrm{HH}}=$ $1.3 \mathrm{~Hz}, 1 \mathrm{H}, 5$ - or 6-indenyl $\mathrm{CH}$ ), 7.31 (apparent t, ${ }^{3} \mathrm{~J}_{\mathrm{HH}}=7.5 \mathrm{~Hz}, 5$ - or 6-indenyl $\mathrm{CH}$ ), 7.35 $\left(\mathrm{d},{ }^{3} \mathrm{~J}_{\mathrm{HH}}=7.1 \mathrm{~Hz}\right.$, 4- or 7-indenyl CH), $7.45\left(\mathrm{~d},{ }^{3} \mathrm{~J}_{\mathrm{HH}}=7.4 \mathrm{~Hz}\right.$, 4- or 7-indenyl $\left.\mathrm{CH}\right) .\left\{{ }^{1} \mathrm{H}\right\}^{13} \mathrm{C}$ NMR (126 MHz, $\mathrm{CDCl}_{3}, 23^{\circ} \mathrm{C}$ ): $\delta 13.27\left(\mathrm{CH}_{3}\right), 37.87$ (1-indenyl $\mathrm{CH}_{2}$ ), 119.02 (indenyl $\mathrm{CH}$ ), 123.79 (indenyl $\mathrm{CH}$ ), 124.63 (indenyl $\mathrm{CH}$ ), 126.23 (indenyl $\mathrm{CH}$ ), 128.94 (2-indenyl $\mathrm{CH}$ ), 140.12 (3a-indenyl C), 144.51 (7a-indenyl C), 146.30 (3-indenyl C). ${ }^{1} \mathrm{H}$ and ${ }^{13} \mathrm{C}$ NMR spectra are consistent with previously reported data. ${ }^{22}$

1-methyl-1H-indene (19c). A $100 \mathrm{~mL}$ oven-dried schlenk flask was charged with $30 \mathrm{~mL}$ diethyl ether, $4.49 \mathrm{~g}(38.6 \mathrm{mmol})$ of freshly-distilled indene and cooled to $-78^{\circ} \mathrm{C}$ on a schlenk line. To the stirred reaction flask was added $25 \mathrm{~mL}(42.5$ mmol, $1.7 \mathrm{M}$ in hexane) of tert-butyllithium via cannula transfer. The reaction flask was allowed to warm to room temperature and was stirred for four hours. Following cooling to $-78 \stackrel{\circ}{\circ}, 5.48 \mathrm{~g}(38.6 \mathrm{mmol}, 4.51 \mathrm{~mL})$ of iodomethane was added via syringe, and upon completion, the reaction flask was allowed to warm to room temperature. The reaction mixture was slowly hydrolyzed with $50 \mathrm{~mL}$ water and extracted with hexane $(2 \times 50 \mathrm{~mL})$. The organic layers were combined, washed with $30 \mathrm{~mL}$ brine and dried over sodium sulfate. Upon filtration and solvent removal, the crude alkene was purified via fractional distillation (the fraction containing the product distilled over under dynamic vacuum with 
the boiling point of $24 \stackrel{\circ}{\circ}$ using the schlenk line vacuum), affording $2.57 \mathrm{~g}(19.7 \mathrm{mmol}$, $51 \%$ yield) of 1 -methyl- $1 \mathrm{H}$-indene (19c) as a pale yellow oil. ${ }^{1} \mathrm{H} \mathrm{NMR}\left(500 \mathrm{MHz}, \mathrm{C}_{6} \mathrm{D}_{6}\right.$, $23 \stackrel{\circ}{\circ}): \delta 1.33\left(\mathrm{~d},{ }^{3} J_{\mathrm{HH}}=7.8 \mathrm{~Hz}, 3 \mathrm{H}, \mathrm{CH}_{3}\right), 3.50\left(\mathrm{q},{ }^{3} J_{\mathrm{HH}}=7.5 \mathrm{~Hz}, 1 \mathrm{H}, 1\right.$-indenyl $\left.\mathrm{CH}\right), 6.49$ $\left(\mathrm{d},{ }^{3} \mathrm{~J}_{\mathrm{HH}}=5.2 \mathrm{~Hz}, 1 \mathrm{H}, 2\right.$-indenyl $\left.\mathrm{CH}\right), 6.79\left(\mathrm{~d},{ }^{3} \mathrm{~J}_{\mathrm{HH}}=5.4 \mathrm{~Hz}, 3\right.$-indenyl $\left.\mathrm{CH}\right), 7.21\left(\mathrm{t},{ }^{3} \mathrm{~J}_{\mathrm{HH}}=\right.$ $7.2 \mathrm{~Hz}, 5$ - or 6-indenyl $\mathrm{CH}$ ), 7.26 (t overlapping with residual solvent peak, 5- or 6indenyl $\mathrm{CH}$ ), $7.36\left(\mathrm{~d},{ }^{3} \mathrm{~J}_{\mathrm{HH}}=7.4 \mathrm{~Hz}\right.$, 4- or 7-indenyl $\left.\mathrm{CH}\right), 7.43\left(\mathrm{~d},{ }^{3} \mathrm{~J}_{\mathrm{HH}}=7.3 \mathrm{~Hz}\right.$, 4- or 7indenyl $\mathrm{CH}) .\left\{{ }^{1} \mathrm{H}\right\}^{13} \mathrm{C}$ NMR (126 MHz, $\left.\mathrm{CDCl}_{3}, 23^{\circ} \mathrm{C}\right): \delta 16.20,45.29,121.18,122.80$, 124.92, 126.57, 130.31, 141.56, 144.09, 149.37. ${ }^{1} \mathrm{H}$ and ${ }^{13} \mathrm{C}$ NMR spectra are consistent with previously reported data. ${ }^{23}$

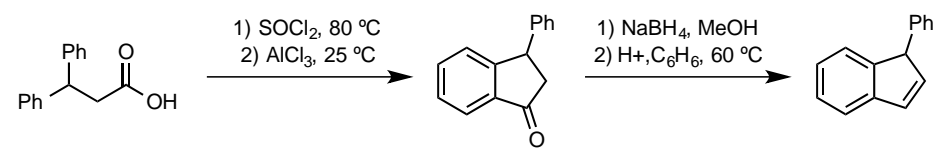

1-phenyl-1H-indene (1g). A $100 \mathrm{~mL}$ oven-dried schlenk flask was charged with a magnetic stir bar, $5.00 \mathrm{~g}$ (22.10 mmol) 3,3-diphenylpropanoic acid, and $20 \mathrm{~mL}$ (274 mmol) thionyl chloride. The schlenk flask was equipped with a reflux condenser that was fitted with a hose connected to an aqueous sodium bicarbonate bath. The reaction flask was heated to $80^{\circ} \mathrm{C}$ for 12 hours with stirring. Following cooling to room temperature, the excess thionyl chloride was removed via vacuum distillation. The solid residue was suspended in $10 \mathrm{~mL}$ toluene which was then removed via vacuum distillation. The crude acyl chloride (used without further purification) was dissolved in $100 \mathrm{~mL}$ of dichloromethane and transferred to a $250 \mathrm{~mL}$ schlenk flask equipped with a stir bar. Under inert atmosphere, $2.95 \mathrm{~g}(22.1 \mathrm{mmol})$ of $\mathrm{AlCl}_{3}$ was added in portions. The reaction flask was stirred at room temperature for 12 hours, after which it was slowly hydrolyzed with water. The reaction mixture was extracted with dichloromethane $(2 \times 50 \mathrm{~mL})$, and the organic layers were combined and washed with brine and dried over sodium sulfate. Following filtration and solvent evaporation, the crude ketone was purified via column chromatography using $10 \%$ ethyl acetate in hexane as the eluent to afford $2.015 \mathrm{~g}(9.68$ 
mmol, $44 \%$ yield) of a brown solid identified as 3-phenyl-1-indanone. ${ }^{1} \mathrm{H} \mathrm{NMR}(500 \mathrm{MHz}$, $\left.\mathrm{CDCl}_{3}, 23 \stackrel{\circ}{\circ} \mathrm{C}\right): \delta 2.69\left(\mathrm{dd},{ }^{2} \mathrm{~J}_{\mathrm{HH}}=19.2 \mathrm{~Hz},{ }^{3} \mathrm{JHH}_{\mathrm{HH}}=3.8 \mathrm{~Hz}, 1 \mathrm{H}\right.$, diastereotopic 2-indanone $\mathrm{CH}$, $3.23\left(\mathrm{dd},{ }^{2} \mathrm{JHH}_{\mathrm{H}}=19.2 \mathrm{~Hz},{ }^{3} \mathrm{JHH}_{\mathrm{H}}=8.0 \mathrm{~Hz}, 1 \mathrm{H}\right.$, diastereotopic 2-indanone $\mathrm{CH}$ ), 4.58 (dd, ${ }^{3} \mathrm{~J}_{\mathrm{HH}}=8.2 \mathrm{~Hz},{ }^{3} \mathrm{~J}_{\mathrm{HH}}=3.8 \mathrm{~Hz}, 1 \mathrm{H}, 3$-indanone $\mathrm{CH}$ ). $7.12\left(\mathrm{~d},{ }^{3} \mathrm{~J}_{\mathrm{HH}}=7.5 \mathrm{~Hz}, 2 \mathrm{H}\right.$, phenyl $\mathrm{CH}$ ), 7.22-7.29 (overlapping $\mathrm{m}, 2 \mathrm{H}$, phenyl $\mathrm{CH}$, aryl $\mathrm{CH}$ ), 7.29-7.34 (m, $2 \mathrm{H}$, phenyl $\mathrm{CH}$ ), $7.41\left(\mathrm{t},{ }^{3} J_{\mathrm{HH}}=7.4 \mathrm{~Hz}, 1 \mathrm{H}\right.$, aryl CH), $7.56\left(\mathrm{t},{ }^{3} \mathrm{~J}_{\mathrm{HH}}=7.5 \mathrm{~Hz}, 1 \mathrm{H}\right.$, aryl $\left.\mathrm{CH}\right), 7.81\left(\mathrm{~d},{ }^{3} \mathrm{JHH}_{\mathrm{HH}}=\right.$ 7.7 Hz, $1 \mathrm{H}$, aryl $\mathrm{CH}$ ). ${ }^{1} \mathrm{H}$ and ${ }^{13} \mathrm{C}$ NMR spectra are consistent with previously reported data. ${ }^{24}$ A $250 \mathrm{~mL}$ round bottom flask was charged with a magnetic stirbar, $50 \mathrm{~mL}$ methanol and $1.815 \mathrm{~g}(8.72 \mathrm{mmol})$ of 3-phenyl-1-indanone and cooled to $0 \stackrel{\circ}{\circ} \mathrm{C}$. To the flask was added $0.495 \mathrm{~g}(13.07 \mathrm{mmol})$ of $\mathrm{NaBH}_{4}$ in portions over 15 minutes with concomitant evolution of gas bubbles from the reaction mixture. The reaction flask was stirred for 3 hours, at which point gas evolution had stopped. The reaction mixture was diluted with $200 \mathrm{~mL}$ ethyl acetate and extracted with water $(3 \times 50 \mathrm{~mL})$. The organic layer was washed with brine and dried over sodium sulfate. Following filtration and solvent evaporation, the crude alcohol was transferred to a $200 \mathrm{~mL}$ schlenk flask and dissolved in $100 \mathrm{~mL}$ benzene. To the reaction flask was added $0.30 \mathrm{~g}(1.6 \mathrm{mmol}) \mathrm{p}$ toluenesulfonic acid. The reaction was heated to reflux for 6 hours with removal of water with a Dean-Stark apparatus. Following cooling and solvent evaporation, the residue was dissolved in $150 \mathrm{~mL}$ ethyl acetate and extracted with conc. aqueous $\mathrm{NaHCO}_{3}(100$ $\mathrm{mL}$ ) and brine. The organics were dried over sodium sulfate and filtered and the solvent was removed. The crude product was purified via column chromatography using hexane as the eluent to afford $1.116 \mathrm{~g}(8.72 \mathrm{mmol}, 67 \%$ yield) of 1 -phenyl-1 $\mathrm{H}$-indene $(\mathbf{1 g})$ as a clear oil. ${ }^{1} \mathrm{H}$ NMR (500 MHz, $\left.\mathrm{CDCl}_{3}, 23 \stackrel{\circ}{\circ} \mathrm{C}\right): \delta 4.62\left(\mathrm{t},{ }^{3} \mathrm{JHH}_{\mathrm{HH}}=2.2 \mathrm{~Hz}, 1 \mathrm{H}, 1\right.$-indenyl $\left.\mathrm{CH}\right)$, $6.61\left(\mathrm{dd},{ }^{3} \mathrm{~J}_{\mathrm{HH}}=5.5 \mathrm{~Hz},{ }^{3} \mathrm{~J}_{\mathrm{HH}}=2.0 \mathrm{~Hz}, 1 \mathrm{H}\right.$, alkenyl $\left.\mathrm{CH}\right), 6.92\left(\mathrm{dd},{ }^{3} J_{\mathrm{HH}}=5.7 \mathrm{~Hz},{ }^{3} \mathrm{~J}_{\mathrm{HH}}=\right.$ $1.8 \mathrm{~Hz}, 1 \mathrm{H}$, alkenyl $\mathrm{CH}), 7.11-7.14(\mathrm{~m}, 2 \mathrm{H}$, phenyl $\mathrm{CH}), 7.16\left(\mathrm{dt},{ }^{3} \mathrm{~J}_{\mathrm{HH}}=7.1 \mathrm{~Hz},{ }^{4} J_{\mathrm{HH}}=0.8\right.$ $\mathrm{Hz}, 1 \mathrm{H}$, aryl $\mathrm{CH}$ ), $7.23(\mathrm{~m}, 1 \mathrm{H}, p$-phenyl $\mathrm{CH}$ ), 7.25-7.30 (overlapping $\mathrm{m}, 4 \mathrm{H}$, aryl $\mathrm{CH}$, 
phenyl CH), $7.41\left(\mathrm{~d},{ }^{3} \mathrm{JHH}_{\mathrm{HH}}=7.5 \mathrm{~Hz}, 1 \mathrm{H}\right.$, aryl CH). $\left\{{ }^{1} \mathrm{H}\right\}^{13} \mathrm{C} \mathrm{NMR}\left(126 \mathrm{MHz}, \mathrm{CDCl}_{3}, 23^{\circ} \mathrm{C}\right)$ : $\delta 56.86,121.35,124.08,125.48,126.97,126.99,128.01,128.87,131.73,139.48$, 139.94, 144.26, 148.39. ${ }^{1} \mathrm{H}$ and ${ }^{13} \mathrm{C}$ NMR spectra are consistent with previously reported data. $^{25}$

3-methylbenzofuran. According to a literature procedure, ${ }^{26}$ a $250 \mathrm{~mL}$ ovendried schlenk flask was charged with $0.654 \mathrm{~g}(16.35 \mathrm{mmol})$ sodium hydride (60\% dispersed in paraffin oil) under argon and rinsed with pentane $(2 \times 10 \mathrm{ml})$. The flask was charged with a magnetic stir bar, $3.60 \mathrm{~g}(16.35 \mathrm{mmol})$ trimethylsulfoxonium iodide, and $45 \mathrm{~mL}$ DMSO. The reaction was stirred for 45 minutes, then $1.484 \mathrm{~g}$ (10.9 mmol) of 2'-hydroxyacetophenone in $25 \mathrm{~mL}$ DMSO was added. The reaction mixture was heated to $40{ }^{\circ} \mathrm{C}$ and stirred for $18 \mathrm{hr}$. Water $(200 \mathrm{~mL})$ was then added to the reaction mixture, which was then extracted with diethyl ether $(3 \times 75 \mathrm{~mL})$. The organic layers were combined, washed with $50 \mathrm{~mL}$ brine, and dried over sodium sulfate. Following solvent removal, the crude alkene was purified via column chromatography $\left(R_{f}\right.$ $=0.4$ in hexane $)$ to afford $0.468 \mathrm{~g}(3.5 \mathrm{mmol}, 33 \%)$ of 3-methylbenzofuran as a clear oil. ${ }^{1} \mathrm{H}$ NMR $\left(500 \mathrm{MHz}, \mathrm{CDCl}_{3}, 23 \stackrel{\circ}{\circ}\right)$ ): $\delta 2.26\left(\mathrm{~m}, 3 \mathrm{H}, \mathrm{CH}_{3}\right), 7.24-7.28(\mathrm{~m}, 1 \mathrm{H}, 5-$ or $6-$ benzofuryl $\mathrm{CH}$, $7.30\left(\mathrm{t},{ }^{3} \mathrm{~J}_{\mathrm{HH}}=7.6 \mathrm{~Hz}, 1 \mathrm{H}, 5\right.$ - or 6-benzofuryl $\left.\mathrm{CH}\right), 7.42(\mathrm{~s}, 1 \mathrm{H}, 2$ benzofuryl $\mathrm{CH}), 7.42\left(\mathrm{~d},{ }^{3} \mathrm{~J}_{\mathrm{HH}}=7.9 \mathrm{~Hz}, 1 \mathrm{H}, 4\right.$ - or 7 -benzofuryl $\left.\mathrm{CH}\right), 7.54\left(\mathrm{~d},{ }^{3} J_{\mathrm{HH}}=7.6\right.$ $\mathrm{Hz}, 1 \mathrm{H}$, 4- or 7-benzofuryl $\mathrm{CH}) \cdot\left\{{ }^{1} \mathrm{H}\right\}^{13} \mathrm{C}$ NMR $\left(126 \mathrm{MHz}, \mathrm{CDCl}_{3}, 23^{\circ} \mathrm{C}\right): \delta 8.12,111.50$, 115.80, 119.59, 122.39, 124.24, 129.19, 141.53, 155.41. ${ }^{1} \mathrm{H}$ and ${ }^{13} \mathrm{C}$ NMR spectra are consistent with previously reported data. ${ }^{27}$<smiles>Oc1ccccc1I</smiles><smiles>O=C(CBr)c1ccccc1</smiles>

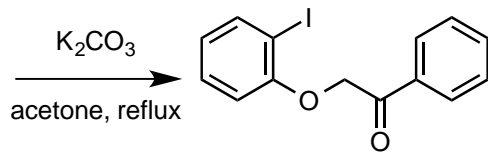
2) $p$ - $\mathrm{TsOH}$, acetone<smiles>c1ccc(-c2coc3ccccc23)cc1</smiles>

3-phenylbenzofuran. According to an adapted literature procedure, ${ }^{28}$ a $250 \mathrm{~mL}$ round bottom flask was charged with a magnetic stir bar, $2.189 \mathrm{~g}$ (11 mmol) 1- 
bromoacetophenone, $2.073 \mathrm{~g}(15 \mathrm{mmol})$ potassium carbonate, $2.200 \mathrm{~g}(10 \mathrm{mmol})$ of 2iodophenol, and $100 \mathrm{~mL}$ of acetone. The reaction mixture was heated to reflux for 4 hours, and then cooled to room temperature. The reaction mixture was filtered through celite and the filtrate was concentrated to afford quantitative conversion to 1-(oiodophenoxy)-acetophenone as an off white solid and used without further purification. ${ }^{1} \mathrm{H}$ NMR $\left(500 \mathrm{MHz}, \mathrm{CDCl}_{3}, 23 \stackrel{\circ}{\circ} \mathrm{C}\right): \delta 5.32\left(\mathrm{~s}, 2 \mathrm{H}, \mathrm{OCH}_{2}\right.$ ), 6.71-6.77 (overlapping m, $2 \mathrm{H}$, aryl $\mathrm{CH}), 7.25\left(\mathrm{t},{ }^{3} \mathrm{JHH}_{\mathrm{HH}}=7.7 \mathrm{~Hz}, 1 \mathrm{H}\right.$, phenoxy-aryl $\left.\mathrm{CH}\right), 7.51\left(\mathrm{t},{ }^{3} \mathrm{JHH}_{\mathrm{HH}}=7.7 \mathrm{~Hz}, 2 \mathrm{H}\right.$, acetophenone- $\mathrm{CH}), 7.62\left(\mathrm{t},{ }^{3} \mathrm{~J}_{\mathrm{HH}}=7.5 \mathrm{~Hz}, 1 \mathrm{H}\right.$, phenoxy-aryl $\left.\mathrm{CH}\right), 7.79\left(\mathrm{~d},{ }^{3} \mathrm{~J}_{\mathrm{HH}}=7.9 \mathrm{~Hz}\right.$, $1 \mathrm{H}$, phenoxy-aryl $\mathrm{CH}), 8.04\left(\mathrm{~d},{ }^{3} \mathrm{~J}_{\mathrm{HH}}=8.1 \mathrm{~Hz}, 2 \mathrm{H}\right.$ acetophenone- $\left.\mathrm{CH}\right)$. An oven-dried 250 $\mathrm{mL}$ schlenk flask was charged with a magnetic stir bar, $100 \mathrm{~mL}$ THF, and $20 \mathrm{~mL}$ methyllithium (32 mmol, $1.6 \mathrm{M}$ in diethyl ether). The reaction vessel was cooled to -78 ${ }^{\circ} \mathrm{C}$, and with stirring, $2.664 \mathrm{~g}(7.88 \mathrm{mmol}) 1$-(o-iodophenoxy)-acetophenone (in $10 \mathrm{~mL}$ THF) was added slowly via syringe. The reaction was stirred for 15 minutes at $-78{ }^{\circ} \mathrm{C}$ and then allowed to warm to room temperature. The reaction mixture was slowly hydrolyzed with $5 \mathrm{~mL}$ concentrated aqueous ammonium chloride, followed by the addition of $100 \mathrm{~mL}$ water. The reaction mixture was extracted with diethyl ether $(2 \times 50$ $\mathrm{mL}$ ), the organic layers were combined and washed with $50 \mathrm{~mL}$ brine and dried over sodium sulfate. Evaporation of the solvent afforded the crude alcohol product as an orange oil which was then dissolved in acetone in a round bottom flask. To the reaction vessel was added $0.15 \mathrm{~g}(0.79 \mathrm{mmol}) \mathrm{p}$-toluenesulfonic acid and the reaction was stirred overnight at room temperature. Following solvent evaporation, the crude product was purified via column chromatography using hexane $\left(R_{f}=0.30\right)$ as the eluent to afford 1.23 g $(6.33 \mathrm{mmol}, 80 \%$ yield $)$ of 3-phenylbenzofuran as a clear oil. ${ }^{1} \mathrm{H}$ NMR $(500 \mathrm{MHz}$, $\mathrm{CDCl}_{3}, 23 \stackrel{\circ}{\mathrm{C}}$ ): $\delta$ 7.30-7.40 (m, 1H, 5-benzofuryl $\mathrm{CH}$ ), 7.34-7.41 (overlapping $\mathrm{m}, 2 \mathrm{H}$, phenyl- $\mathrm{CH}$ and 6-benzofuryl $\mathrm{CH}), 7.49\left(\mathrm{t},{ }^{3} \mathrm{~J}_{\mathrm{HH}}=7.7 \mathrm{~Hz}, 2 \mathrm{H}\right.$, phenyl $\left.\mathrm{CH}\right), 7.56\left(\mathrm{t},{ }^{3} \mathrm{~J}_{\mathrm{HH}}=\right.$ 8.1 Hz, 1H, 7-benzofuryl $\mathrm{CH}$ ), 7.64-7.68 (m, 2H, phenyl $\mathrm{CH}), 7.80(\mathrm{~s}, 1 \mathrm{H}, 2$-benzofuryl 
$\mathrm{CH}), 7.86\left(\mathrm{~d},{ }^{3} \mathrm{JHH}_{\mathrm{HH}}=7.6 \mathrm{~Hz}, 1 \mathrm{H}\right.$, 4-benzofuryl $\left.\mathrm{CH}\right) \cdot\left\{{ }^{1} \mathrm{H}\right\}^{13} \mathrm{C}$ NMR $\left(126 \mathrm{MHz}, \mathrm{CDCl}_{3}, 23\right.$ $\left.{ }^{\circ} \mathrm{C}\right): \mathrm{\delta} 111.98,120.60,122.45,123.18,124.76,126.65,127.67,127.71,129.18,132.26$, 141.51, 155.98. ${ }^{1} \mathrm{H}$ and ${ }^{13} \mathrm{C}$ NMR spectra are consistent with previously reported data. ${ }^{29}$

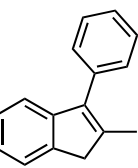

2-methyl-3-phenyl-1H-indene. A 250-mL oven-dried schlenk flask was charged with $100 \mathrm{~mL}$ anhydrous tetrahydrofuran, a magnetic stir bar and 3.05 $\mathrm{g}(20.8 \mathrm{mmol})$ of 2-methyl-1-indanone on a schlenk line. The reaction vessel was cooled to $-78{ }^{\circ} \mathrm{C}$ and $25 \mathrm{~mL}$ of phenylmagnesium bromide (1 $\mathrm{M}$ in 2-Me-THF, $25 \mathrm{mmol}$ ) was added dropwise. The reaction vessel was allowed to warm to room temperature and stirred for an additional 6 hours at room temperature. The vessel was cooled to $0 \stackrel{\circ}{ } \mathrm{C}$ and aqueous ammonium chloride $(10 \mathrm{~mL})$ was slowly added via syringe to quench the reaction. An additional $100 \mathrm{~mL}$ of water were then added upon complete consumption of the Grignard reagent. The reaction mixture was extracted with ethyl acetate $(2 \times 50 \mathrm{~mL})$. The organic layers were combined and washed with $100 \mathrm{~mL}$ of brine and dried with sodium sulfate. Following solvent removal, the crude alcohol was dissolved in toluene and $0.150 \mathrm{~g} p$-toluenesulfonic acid $(0.79 \mathrm{mmol})$ was added. The reaction was heated to reflux for 6 hours with removal of water with a Dean-Stark apparatus. Following cooling and solvent evaporation, the residue was dissolved in $150 \mathrm{~mL}$ ethyl acetate and extracted with conc. aqueous $\mathrm{NaHCO}_{3}(100 \mathrm{~mL})$ and brine. The organics were dried over sodium sulfate and filtered and the solvent was removed. The crude product was purified via column chromatography using hexane as the eluent to afford $3.113 \mathrm{~g}$ (15.1 mmol, $72 \%$ yield) of 2-methyl-3-phenyl-1H-indene as an off-white solid. ${ }^{1} \mathrm{H}$ NMR (500 $\left.\mathrm{MHz}, \mathrm{CDCl}_{3}, 23 \stackrel{\circ}{\circ} \mathrm{C}\right): \delta 2.19\left(\mathrm{~s}, 3 \mathrm{H}, \mathrm{CH}_{3}\right), 3.49\left(\mathrm{~s}, 2 \mathrm{H}, 1\right.$-indenyl $\left.\mathrm{CH}_{2}\right), 7.17-7.23(\mathrm{~m}, 1 \mathrm{H}$, indenyl $\mathrm{CH}$ ), 7.25-7.30 (overlapping $\mathrm{m}, 2 \mathrm{H}$, indenyl $\mathrm{CH}$, phenyl $\mathrm{CH}$ ), 7.37-7.41 (tt, ${ }^{3} \mathrm{JHH}_{\mathrm{HH}}=$ $7.2 \mathrm{~Hz},{ }^{4} J_{H H}=1.3 \mathrm{~Hz}, 1 \mathrm{H}, p$-phenyl $\mathrm{CH}$ ), 7.43-7.53 (overlapping $\mathrm{m}, 5 \mathrm{H}$, indenyl $\mathrm{CH}$, phenyl $\mathrm{CH}$ ). $\left\{{ }^{1} \mathrm{H}\right\}^{13} \mathrm{C}$ NMR (126 MHz, $\mathrm{CDCl}_{3}, 23{ }^{\circ} \mathrm{C}$ ): $\delta 15.06\left(\mathrm{CH}_{3}\right), 43.30$ (1-indenyl $\mathrm{CH}_{2}$ ), 119.47 (indenyl $\mathrm{CH}$ ), 123.58 (7-indenyl $\mathrm{CH}$ ), 124.16 (indenyl $\mathrm{CH}$ ), $126.35(\mathrm{CH})$, 
127.17 (p-phenyl $\mathrm{CH}$ ), 128.59 (o-phenyl $\mathrm{CH}$ ), 129.33 (m-phenyl $\mathrm{CH}$ ), 135.68 (ipso-phenyl C), 138.78 (3-indenyl C), 140.81 (2-indenyl C), 142.59 (7a-indenyl C), 146.54 (3aindenyl C). ${ }^{1} \mathrm{H}$ and ${ }^{13} \mathrm{C}$ NMR spectra are consistent with previously reported data. ${ }^{30}$

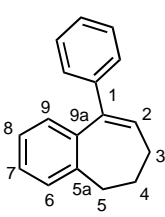

1-phenyl-benzosuberene. A $250-\mathrm{mL}$ oven-dried schlenk flask was charged with $100 \mathrm{~mL}$ anhydrous tetrahydrofuran, a magnetic stir bar and $4.96 \mathrm{~mL}$ of phenylmagnesium bromide (4.96 mmol, $1 \mathrm{M}$ in 2-Me-THF) via cannula transfer. The reaction vessel was cooled to $-78 \stackrel{\circ}{\circ} \mathrm{C}$ and $0.53 \mathrm{~g}(3.31 \mathrm{mmol}) 1$ benzosuberone was added dropwise. The reaction vessel was allowed to warm to room temperature and stirred for an additional 6 hours at room temperature. The vessel was cooled to $0 \stackrel{\circ}{\circ}$ and aqueous ammonium chloride $(10 \mathrm{~mL})$ was slowly added via syringe to quench the reaction. An additional $100 \mathrm{~mL}$ of water were then added upon complete consumption of the Grignard reagent. The reaction mixture was extracted with ethyl acetate $(2 \times 25 \mathrm{~mL})$. The organic layers were combined and washed with $50 \mathrm{~mL}$ of brine and dried with sodium sulfate. Following solvent removal, the crude alcohol was dissolved in toluene and $0.150 \mathrm{~g} p$-toluenesulfonic acid $(0.79 \mathrm{mmol})$ was added. The reaction was heated to reflux for 6 hours with removal of water with a Dean-Stark apparatus. Following cooling and solvent evaporation, the residue was dissolved in 150 $\mathrm{mL}$ ethyl acetate and extracted with conc. aqueous $\mathrm{NaHCO}_{3}(100 \mathrm{~mL})$ and brine. The organics were dried over sodium sulfate and filtered and the solvent was removed. The crude product was purified via column chromatography using hexane as the eluent to afford $0.347 \mathrm{~g}$ (1.57 mmol, $48 \%$ yield) of 1 -phenylbenzosuberene as a clear oil. ${ }^{1} \mathrm{H}$ NMR (500 MHz, $\mathrm{CDCl}_{3}, 2{ }^{\circ}{ }^{\circ} \mathrm{C}$ ): $\delta 1.98$ (apparent q, ${ }^{3} \mathrm{JHH}_{\mathrm{HH}}=7.3 \mathrm{~Hz}, 2 \mathrm{H}, 3$-benzosuberenyl $\mathrm{CH}_{2}$ ), 2.19 (apparent $\mathrm{p},{ }^{3} \mathrm{~J}_{\mathrm{HH}}=7.1 \mathrm{~Hz}, 2 \mathrm{H}, 4$-benzosuberenyl $\mathrm{CH}_{2}$ ), $2.67\left(\mathrm{t},{ }^{3} \mathrm{~J}_{\mathrm{HH}}=7.0 \mathrm{~Hz}, 2 \mathrm{H}\right.$, 5-benzosuberenyl $\left.\mathrm{CH}_{2}\right), 6.46\left(\mathrm{t},{ }^{3} \mathrm{~J}_{\mathrm{HH}}=7.4 \mathrm{~Hz}, 2 \mathrm{H}, 2\right.$-benzosuberenyl $\left.\mathrm{CH}\right), 7.02\left(\mathrm{~d},{ }^{3} \mathrm{~J}_{\mathrm{HH}}\right.$ $=7.2 \mathrm{~Hz}, 1 \mathrm{H}$, aryl $\mathrm{CH}$ ), 7.16-7.24 (overlapping $\mathrm{m}, 2 \mathrm{H}$, aryl $\mathrm{CH}$ ), 7.25-7.33 (overlapping $\mathrm{m}, 6 \mathrm{H}$, aryl $\mathrm{CH}$, phenyl $\mathrm{CH}) \cdot\left\{{ }^{1} \mathrm{H}\right\}^{13} \mathrm{C}$ NMR $\left(126 \mathrm{MHz}, \mathrm{CDCl}_{3}, 23^{\circ} \mathrm{C}\right): \delta 25.57,32.56$, 
$35.45,126.02,127.19,127.23,128.16,128.33,128.75,129.44,140.51,142.39,142.55$ 143.16. ${ }^{1} \mathrm{H}$ and ${ }^{13} \mathrm{C}$ NMR spectra are consistent with previously reported data. ${ }^{31}$<smiles>C=C(c1ccccc1)C1C=CCN1</smiles>
1-phenyl-1-(2-pyridyl)-ethylene. This substrate was prepared according to a literature prep and ${ }^{1} \mathrm{H}$ and ${ }^{13} \mathrm{C}$ NMR spectra are consistent with previously reported data. ${ }^{32}$<smiles>C=C(C1=CC=CC1)c1ccccc1</smiles>

1-phenyl-1-(3-pyridyl)-ethylene. This substrate was prepared according to a literature prep and ${ }^{1} \mathrm{H}$ and ${ }^{13} \mathrm{C}$ NMR spectra are consistent with previously reported data. ${ }^{33}$

\section{Characterization of Alkane Products.}
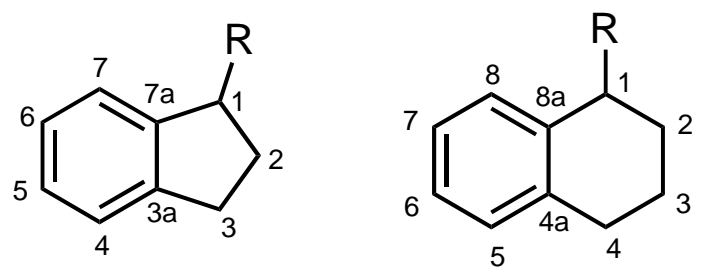

Figure S2. Numbering system for substituted indanes and tetralins.
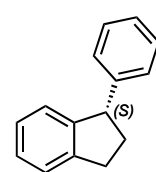

(S)-(-)-1-phenylindane (2a). Using Procedure A with $1.0 \mathrm{mmol}$ substrate 1a and $4 \mathrm{~mL}$ toluene, 2 a was isolated as a clear oil in $98 \%$ yield $(0.190 \mathrm{~g})$ and $94 \%$ ee. $[\alpha]^{23}{ }_{D}=-36.7^{\circ}\left(c 5, \mathrm{CHCl}_{3}\right) .{ }^{1} \mathrm{H}$ NMR $\left(500 \mathrm{MHz}, \mathrm{CDCl}_{3}, 23 \stackrel{\circ}{\circ}\right): \delta$ $2.07(\mathrm{~m}, 1 \mathrm{H}$, pro- $R$ 2-indenyl $\mathrm{CH}), 2.59(\mathrm{~m}, 1 \mathrm{H}$, pro-S 2-indenyl $\mathrm{CH}), 2.96(\mathrm{~m}, 1 \mathrm{H}$, pro- $R$ 3-indenyl $\mathrm{CH}), 3.06(\mathrm{~m}, 1 \mathrm{H}$, pro-S 3-indeyl $\mathrm{CH}), 4.34\left(\mathrm{t},{ }^{3} \mathrm{JHH}_{\mathrm{HH}}=8.38 \mathrm{~Hz}, 1 \mathrm{H}, 1\right.$-indenyl $\mathrm{CH}), 6.96\left(\mathrm{~d},{ }^{3} \mathrm{~J}_{\mathrm{HH}}=7.4 \mathrm{~Hz}, 1 \mathrm{H}\right.$, indenyl aryl $\left.\mathrm{CH}\right), 7.13\left(\mathrm{t},{ }^{3} \mathrm{~J}_{\mathrm{HH}}=7.4 \mathrm{~Hz}, 1 \mathrm{H}\right.$, indenyl aryl $\mathrm{CH}$ ), 7.17-7.25 (overlapping $\mathrm{m}, 4 \mathrm{H}$, phenyl, indenyl aryl $\mathrm{CH}$ ), 7.28-7.34 (overlapping $\mathrm{m}$, $3 \mathrm{H}$, phenyl, indenyl aryl $\mathrm{CH}$ ). See Section $\mathrm{V}$ for determination of diastereotopic aliphatic $\mathrm{CH}$ resonances. $\left\{{ }^{1} \mathrm{H}\right\}^{13} \mathrm{C}$ NMR $\left(126 \mathrm{MHz}, \mathrm{CDCl}_{3}, 23^{\circ} \mathrm{C}\right): \delta 32.05,36.79,51.86,124.55$, 125.12, 126.50, 126.52, 126.74, 128.66, 144.55, 145.61, 147.05. ${ }^{1} \mathrm{H}$ and ${ }^{13} \mathrm{C}$ NMR spectra are consistent with previously reported data. ${ }^{34}$ Chiral separation was achieved 
using chiral GC chromatography according to the following isothermal method: hold at $140{ }^{\circ} \mathrm{C}$ for 80 minutes; ramp $20^{\circ} \mathrm{C}$ per minute, hold at $200{ }^{\circ} \mathrm{C}$ for 6 minutes.

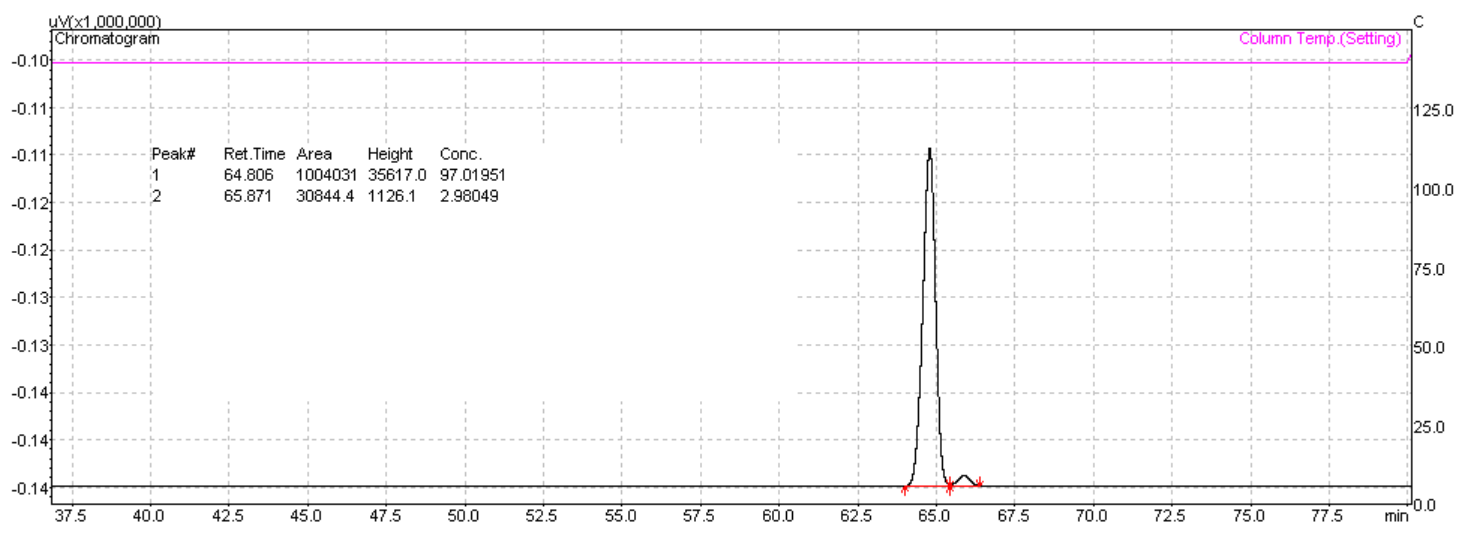

(S)-(-)-1-(4'-methoxyphenyl)indane (2b). Using Procedure A with 1.0 mmol substrate $2 \mathrm{~b}$ and $4 \mathrm{~mL}$ toluene, $2 \mathrm{~b}$ was isolated as a white solid in $74 \%$ yield $(0.165 \mathrm{~g})$ and $96 \%$ ee. Crystals suitable for X-ray diffraction were obtained from slow-evaporation of a concentrated hexane solution. $[\alpha]_{D}^{23}=-33.6^{\circ}$ (c 4.8, $\left.\mathrm{CHCl}_{3}\right) .{ }^{1} \mathrm{H}$ NMR $\left(500 \mathrm{MHz} \mathrm{CDCl}_{3}, 2{ }^{\circ} \mathrm{C}\right): \delta 2.03(\mathrm{~m}, 1 \mathrm{H}, 2$-indenyl $\mathrm{CH}), 2.57$ (m, 1H, 2-indenyl $\mathrm{CH}), 2.94(\mathrm{~m}, 1 \mathrm{H}, 3$-indenyl $\mathrm{CH}), 3.04(\mathrm{~m}, 1 \mathrm{H}, 3$-indenyl $\mathrm{CH}), 3.81(\mathrm{~s}, 3 \mathrm{H}$, $\left.\mathrm{OCH}_{3}\right), 4.30\left(\mathrm{t},{ }^{3} \mathrm{~J}_{\mathrm{HH}}=8.4 \mathrm{~Hz}, 1 \mathrm{H}, 1\right.$-indenyl $\left.\mathrm{CH}\right), 6.86(\mathrm{~m}, 2 \mathrm{H}$, aryl $\mathrm{CH}), 6.96\left(\mathrm{~d},{ }^{3} J_{\mathrm{HH}}=\right.$ 7.4 Hz, $1 \mathrm{H}$, indenyl $\mathrm{CH}$ ), 7.10-7.16 (overlapping $\mathrm{m}, 3 \mathrm{H}$, indenyl $\mathrm{CH}$ and aryl $\mathrm{CH}$ ), 7.21$7.17(\mathrm{~m}, 1 \mathrm{H}$, indenyl $\mathrm{CH}), 7.29\left(\mathrm{~d},{ }^{3} \mathrm{~J}_{\mathrm{HH}}=7.3 \mathrm{~Hz}, 1 \mathrm{H}\right.$, indenyl $\left.\mathrm{CH}\right) \cdot\left\{{ }^{1} \mathrm{H}\right\}^{13} \mathrm{C}$ NMR $(126$ $\left.\mathrm{MHz}, \mathrm{CDCl}_{3}, 23{ }^{\circ} \mathrm{C}\right): \delta 31.97,36.94,51.04,55.46,114.03,124.52,125.04,126.51$, 126.65, 129.23, 137.67, 144.43147.36, 158.29. ${ }^{1} \mathrm{H}$ and ${ }^{13} \mathrm{C}$ NMR spectra are consistent with previously reported data. ${ }^{35}$ Chiral separation was achieved using chiral GC chromatography according to the following isothermal method: hold at $160 \stackrel{\circ}{\mathrm{C}}$ for 180 minutes; ramp $20^{\circ} \mathrm{C}$ per minute, hold at $200^{\circ} \mathrm{C}$ for 6 minutes. 


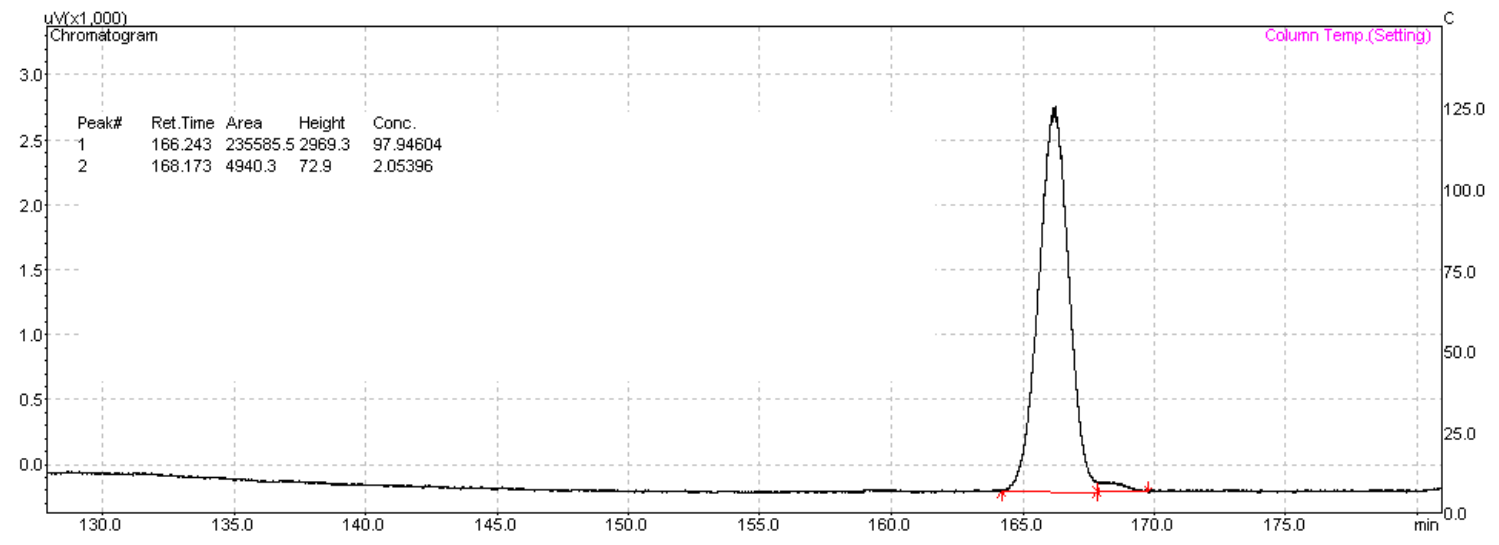

$\backslash_{N-}(S)-(-)-1-(p-d i m e t h y l a m i n o p h e n y l) i n d a n e ~(2 c)$. Using Procedure A with

1. $1.0 \mathrm{mmol}$ substrate $1 \mathrm{c}$ and $4 \mathrm{~mL}$ toluene, $2 \mathrm{c}$ was isolated as a white solid in $97 \%$ yield $(0.231 \mathrm{~g})$ and $99 \%$ ee. Crystals suitable for X-ray diffraction were obtained from slow-evaporation of a concentrated hexane solution. $[\alpha]^{23}{ }_{D}=-38.5^{\circ}(c 5$, $\left.\mathrm{CHCl}_{3}\right) .{ }^{1} \mathrm{H}$ NMR $\left(500 \mathrm{MHz}, \mathrm{CDCl}_{3}, 23^{\circ} \mathrm{C}\right): \delta 2.03(\mathrm{~m}, 1 \mathrm{H}, 2$-indenyl $\mathrm{CH}), 2.54(\mathrm{~m}, 1 \mathrm{H}, 2-$ indenyl $\mathrm{CH}$ ), 2.89-2.97 (overlapping $\mathrm{m}, 7 \mathrm{H}, \mathrm{N}\left(\mathrm{CH}_{3}\right)_{2}$ and 3-indenyl $\mathrm{CH}$ ), 3.00-3.07 (m, $1 \mathrm{H}$, 3-indenyl $\mathrm{CH}), 4.26\left(\mathrm{t},{ }^{3} \mathrm{~J}_{\mathrm{HH}}=8.4 \mathrm{~Hz}, 1 \mathrm{H}, 1\right.$-indenyl $\left.\mathrm{CH}\right), 6.72\left(\mathrm{~d},{ }^{3} \mathrm{~J}_{\mathrm{HH}}=8.4 \mathrm{~Hz}, 2 \mathrm{H}\right.$, aryl $\mathrm{CH}$ ), $6.98\left(\mathrm{~d},{ }^{3} \mathrm{~J}_{\mathrm{HH}}=7.2 \mathrm{~Hz}, 1 \mathrm{H}\right.$, indenyl $\left.\mathrm{CH}\right), 7.08\left(\mathrm{~d},{ }^{3} \mathrm{~J}_{\mathrm{HH}}=8.0 \mathrm{~Hz}, 2 \mathrm{H}\right.$, aryl $\left.\mathrm{CH}\right)$, $7.13\left(\mathrm{t},{ }^{3} \mathrm{~J}_{\mathrm{HH}}=7.4 \mathrm{~Hz}, 1 \mathrm{H}\right.$, indenyl $\left.\mathrm{CH}\right), 7.17\left(\mathrm{t},{ }^{3}{ }^{\mathrm{HH}}=7.4 \mathrm{~Hz}, 1 \mathrm{H}\right.$, indenyl $\left.\mathrm{CH}\right), 7.28(\mathrm{~d}$, ${ }^{3} J_{H H}=7.2 \mathrm{~Hz}, 1 \mathrm{H}$, indenyl $\left.\mathrm{CH}\right) \cdot\left\{{ }^{1} \mathrm{H}\right\}^{13} \mathrm{C}$ NMR $\left(126 \mathrm{MHz}, \mathrm{CDCl}_{3}, 23^{\circ} \mathrm{C}\right): \delta 31.98,36.96$, $41.03,50.95,113.05,124.44,125.10,126.42,126,47,128.93,133.55,144.47,147.77$, 149.50. ${ }^{1} \mathrm{H}$ and ${ }^{13} \mathrm{C}$ NMR spectra are consistent with previously reported data. ${ }^{36}$ Chiral separation was achieved using chiral SFC analysis (AD-H, $15 \% \mathrm{MeOH} / \mathrm{CO}_{2}, 3.0 \mathrm{~mL} / \mathrm{mol}$, $220 \mathrm{~nm})$. 

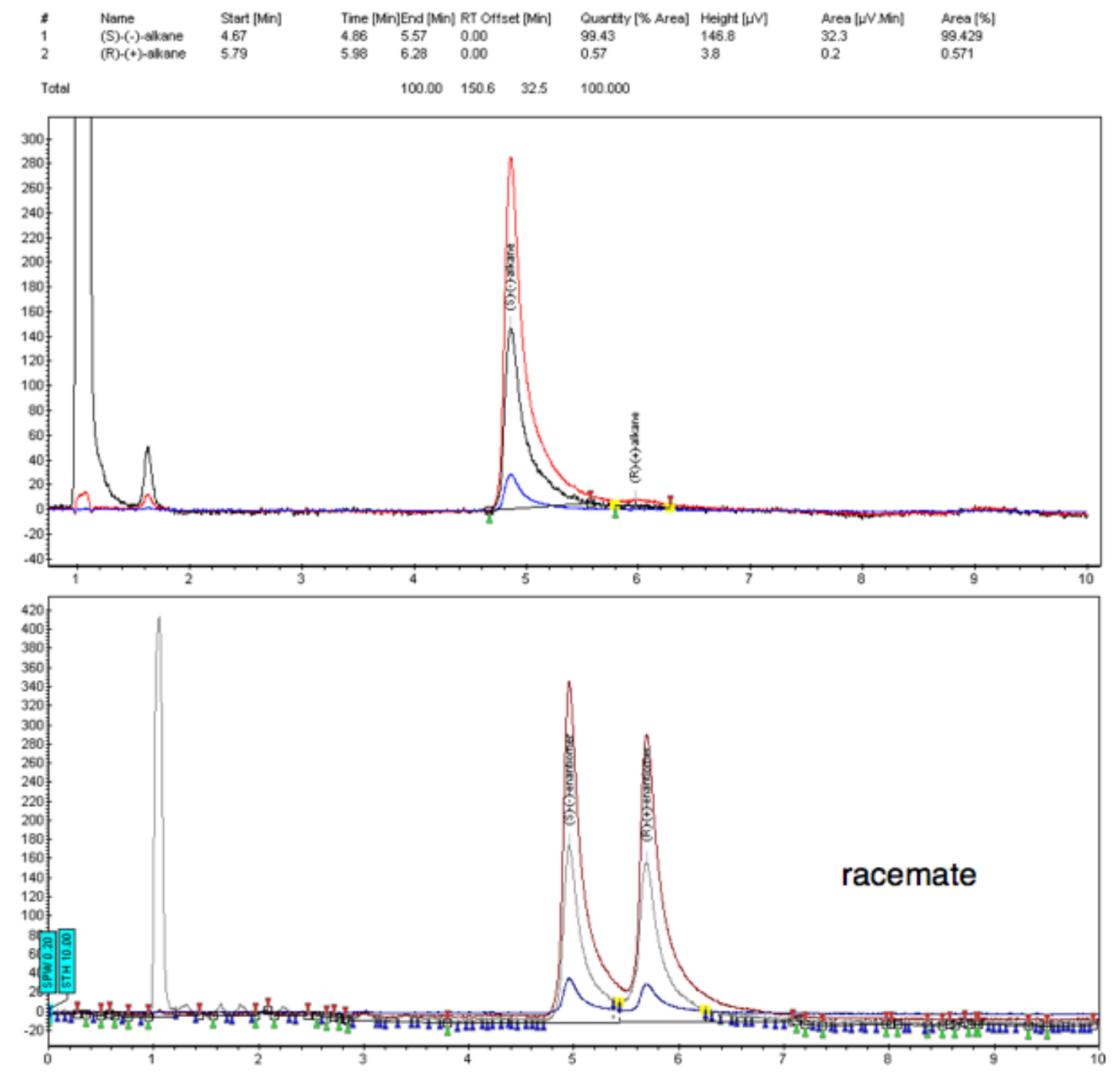

(S)-(-)-1-(4'-chlorophenyl)indane (2d). Using Procedure A with $1.0 \mathrm{mmol}$

substrate $1 \mathrm{~d}$ and $4 \mathrm{~mL}$ toluene, $2 \mathrm{~d}$ was isolated as a white solid (after cooling to $-35 \stackrel{\circ}{\circ}$ for 24 hours) in $89 \%$ yield $(0.203 \mathrm{~g})$ and $96 \%$ ee. Crystals suitable for X-ray diffraction were grown using slow-evaporation from a concentrated hexane solution. $[\alpha]^{23}{ }_{D}=-30.3^{\circ}\left(c 5, \mathrm{CHCl}_{3}\right) .{ }^{1} \mathrm{H} \mathrm{NMR}\left(500 \mathrm{MHz}, \mathrm{CDCl}_{3}, 2{ }^{\stackrel{\circ}{ } \mathrm{C}}\right): \delta 2.01(\mathrm{~m}, 1 \mathrm{H}$, 2-indenyl $\mathrm{CH}$ ), $2.58(\mathrm{~m}, 1 \mathrm{H}$, 2-indenyl $\mathrm{CH}), 2.95(\mathrm{~m}, 1 \mathrm{H}, 3$-indenyl $\mathrm{CH}), 3.05(\mathrm{~m}, 1 \mathrm{H}, 3-$ indenyl $\mathrm{CH}), 3.81\left(\mathrm{~s}, 3 \mathrm{H}, \mathrm{OCH}_{3}\right), 4.32\left(\mathrm{t},{ }^{3} \mathrm{~J}_{\mathrm{HH}}=8.4 \mathrm{~Hz}, 1 \mathrm{H}, 1\right.$-indenyl $\left.\mathrm{CH}\right), 6.93\left(\mathrm{~d},{ }^{3} \mathrm{~J}_{\mathrm{HH}}=\right.$ $7.2 \mathrm{~Hz}, 1 \mathrm{H}$, indenyl $\mathrm{CH}$ ), 7.10-7.17 (overlapping $\mathrm{m}, 3 \mathrm{H}$, indenyl and aryl $\mathrm{CH}$ ), 7.20 (t, 
${ }^{3} \mathrm{~J}_{\mathrm{HH}}=7.3 \mathrm{~Hz}, 1 \mathrm{H}$, indenyl $\mathrm{CH}$ ), 7.25-7.32 (overlapping $\mathrm{m}, 3 \mathrm{H}$, indenyl and aryl $\mathrm{CH}$ ). $\left\{{ }^{1} \mathrm{H}\right\}^{13} \mathrm{C}$ NMR $\left(126 \mathrm{MHz}, \mathrm{CDCl}_{3}, 23{ }^{\circ} \mathrm{C}\right): \delta 31.97,36.81,51.52,124.64,124.99,126.66$, 126.94, 128.78, 129.66, 132.16, 144.14, 144.49, 146.53. HR-MS (+El): Calc'd for: $\mathrm{C}_{15} \mathrm{H}_{13} \mathrm{Cl},[\mathrm{M}]^{++}, \mathrm{m} / \mathrm{z}$ 228.07058. Found $\mathrm{m} / \mathrm{z}$ 228.0702. Chiral separation was achieved using chiral GC chromatography according to the following isothermal method: hold at $170 \stackrel{\circ}{ } \mathrm{C}$ for 120 minutes; ramp $20^{\circ} \mathrm{C}$ per minute, hold at $200 \stackrel{\circ}{\mathrm{C}}$ for 6 minutes.

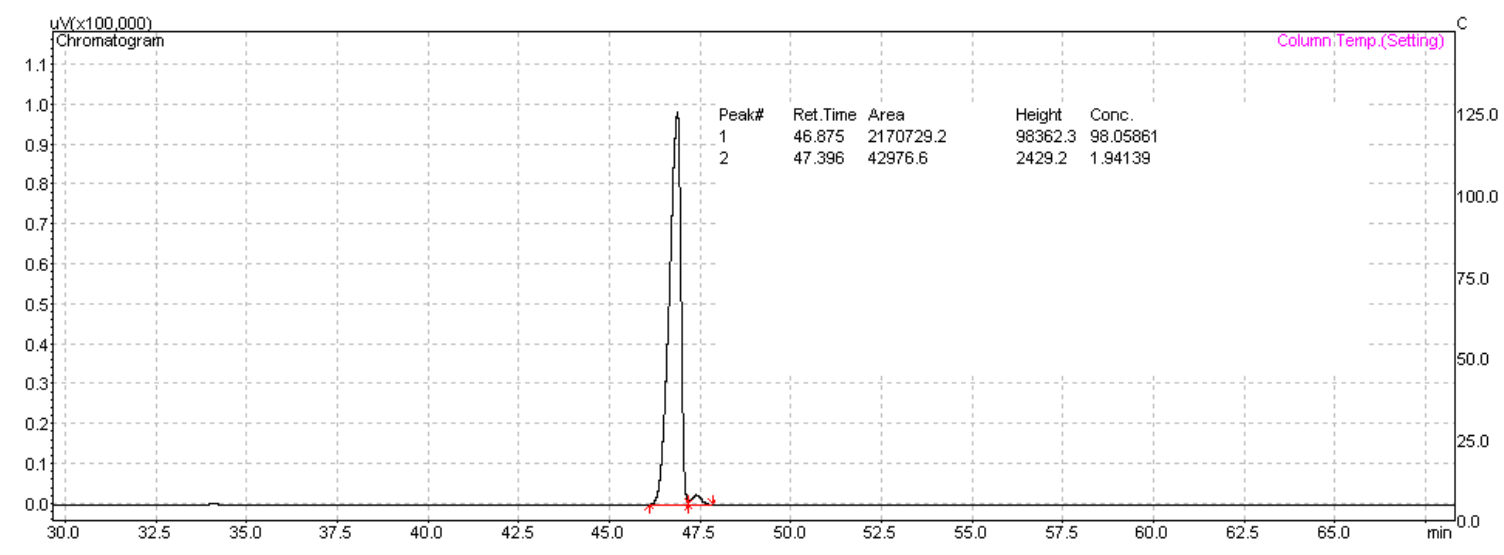

(S)-(-)-1-(4'-fluorophenyl)indane (2e). Using Procedure A with $1.0 \mathrm{mmol}$ substrate $1 \mathrm{e}, 4 \mathrm{~mL}$ toluene and $1 \mathrm{~atm} \mathrm{H}_{2}, 2 \mathrm{e}$ was isolated as a clear oil in $96 \%$ yield $(0.203 \mathrm{~g})$ and $97 \%$ ee. At 4 atm $\mathrm{H}_{2}$, the product was obtained in $97 \%$ yield $(0.206 \mathrm{~g})$ and $85 \%$ ee. $[\alpha]^{23}{ }_{\mathrm{D}}=-37.4^{\circ}$ (c $5,85 \%$ ee, $\left.\mathrm{CHCl}_{3}\right) .{ }^{1} \mathrm{H}$ NMR $(500$ $\left.\mathrm{MHz}, \mathrm{CDCl}_{3}, 23^{\circ} \mathrm{C}\right): \delta 2.01(\mathrm{~m}, 1 \mathrm{H}, 2$-indenyl $\mathrm{CH}), 2.58(\mathrm{~m}, 1 \mathrm{H}, 2$-indenyl $\mathrm{CH}), 2.95(\mathrm{~m}$, $1 \mathrm{H}, 3$-indenyl $\mathrm{CH}), 3.05(\mathrm{~m}, 1 \mathrm{H}, 3$-indenyl $\mathrm{CH}), 4.33\left(\mathrm{t},{ }^{3} \mathrm{JHH}_{\mathrm{HH}}=8.3 \mathrm{~Hz}, 1 \mathrm{H}, 1\right.$-indenyl $\left.\mathrm{CH}\right)$, $6.93\left(\mathrm{~d},{ }^{3} \mathrm{JHH}_{\mathrm{H}}=7.4 \mathrm{~Hz}, 1 \mathrm{H}, 7\right.$-indenyl $\left.\mathrm{CH}\right), 6.96-7.02(\mathrm{~m}, 2 \mathrm{H}, 3$-aryl $\mathrm{CH}), 7.12-7.17$ (overlapping m, 3H, 6-indenyl CH, 2-aryl CH), $7.20\left(\mathrm{tt},{ }^{3} \mathrm{~J}_{\mathrm{HH}}=7.3 \mathrm{~Hz},{ }^{4} \mathrm{~J}_{\mathrm{HH}}=0.95 \mathrm{~Hz}, 5\right.$ indenyl $\mathrm{CH}), 7.30\left(\mathrm{~d},{ }^{3} \mathrm{JHH}_{\mathrm{HH}}=7.4 \mathrm{~Hz}, 1 \mathrm{H}, 4\right.$-indenyl $\left.\mathrm{CH}\right) \cdot\left\{{ }^{1} \mathrm{H}\right\}^{13} \mathrm{C} \mathrm{NMR}\left(126 \mathrm{MHz}, \mathrm{CDCl}_{3}\right.$, $23{ }^{\circ} \mathrm{C}$ ): $\delta 31.95$ (s, 2-indenyl $\mathrm{CH}_{2}$ ), 36.93 (s, 3-indenyl $\mathrm{CH}_{2}$ ), 51.09 (s, 1-indenyl $\mathrm{CH}$ ), $115.40\left(\mathrm{~d},{ }^{2} \mathrm{JFF}_{\mathrm{CF}}=21.3 \mathrm{~Hz}, 3\right.$-aryl $\mathrm{CH}$ ), 124.61 (s, indenyl $\mathrm{CH}$ 4-indenyl), 125.00 (s, indenyl $\mathrm{CH}$ 7-indenyl), 126.62 (s, indenyl $\mathrm{CH}$ 5-indenyl), 126.86 (s, 6-indenyl $\mathrm{CH}$ ), $129.67\left(\mathrm{~d},{ }^{3} \mathrm{~J}_{\mathrm{CF}}=7.8 \mathrm{~Hz}, 2\right.$-aryl CH), $141.26\left(\mathrm{~d},{ }^{4} \mathrm{~J}_{\mathrm{CF}}=3.2 \mathrm{~Hz}\right.$, ipso-aryl C), 144.44 (s, 4a- 
indenyl), 146.86 (s, 7a-indenyl), 161.70 (d $\left.{ }^{1} J_{\mathrm{CF}}=244 \mathrm{~Hz}, 4-C F\right)$. HR-MS (+El): Calc'd for: $\mathrm{C}_{15} \mathrm{H}_{13} \mathrm{~F},[\mathrm{M}]^{++}, \mathrm{m} / \mathrm{z}$ 212.0996. Found $\mathrm{m} / \mathrm{z} 2$ 212.0992. Chiral separation was achieved using chiral GC chromatography according to the following isothermal method: hold at $150 \stackrel{\circ}{\circ}$ for 60 minutes; ramp $20 \stackrel{\circ}{ } \mathrm{C}$ per minute, hold at $200 \stackrel{\circ}{ } \mathrm{C}$ for 6 minutes.
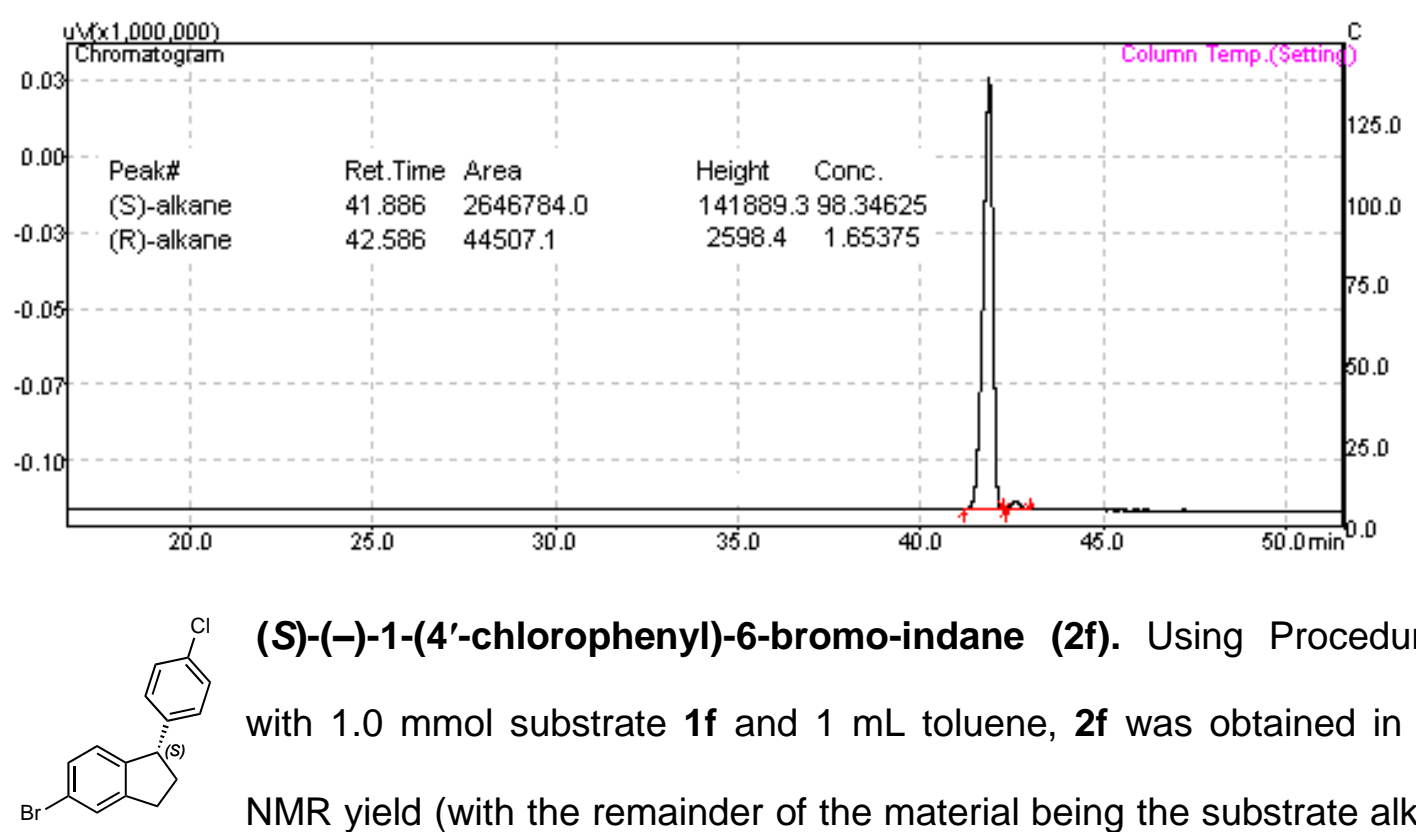

(S)-(-)-1-(4'-chlorophenyl)-6-bromo-indane (2f). Using Procedure A with $1.0 \mathrm{mmol}$ substrate $\mathbf{1 f}$ and $1 \mathrm{~mL}$ toluene, $\mathbf{2 f}$ was obtained in $54 \%$ NMR yield (with the remainder of the material being the substrate alkene) and $91 \%$ ee. $[\alpha]^{23} \mathrm{D}=-13.9^{\circ}$ (c 7.1 including unreacted alkene, $\mathrm{CHCl}_{3}$ ). ${ }^{1} \mathrm{H}$ NMR (500 $\left.\mathrm{MHz}, \mathrm{CDCl}_{3}, 23 \stackrel{\circ}{\circ} \mathrm{C}\right): \delta 2.01$ ( $\mathrm{m}, 1 \mathrm{H}, 2$-indenyl $\mathrm{CH}$ ), 2.58 (m, 1H, 2-indenyl $\mathrm{CH}$ ), 2.87-3.08 (m, $2 \mathrm{H}$, diastereotopic 3-indenyl $\mathrm{CH}$ resonances), $4.25\left(\mathrm{t},{ }^{3} \mathrm{JHH}_{\mathrm{HH}}=8.4 \mathrm{~Hz}, 1 \mathrm{H}, 1\right.$-indenyl $\mathrm{CH}), 6.81\left(\mathrm{~d},{ }^{3} \mathrm{JHH}_{\mathrm{H}}=8.1 \mathrm{~Hz}, 1 \mathrm{H}, 7\right.$-indenyl $\left.\mathrm{CH}\right), 7.08(\mathrm{~m}, 2 \mathrm{H}$, aryl $\mathrm{CH}), 7.15-7.30$ (overlapping $\mathrm{m}, 2 \mathrm{H}$ ), 7.35-7.52 (overlapping $\mathrm{m}, 2 \mathrm{H}$ ). $\left\{{ }^{1} \mathrm{H}{ }^{13} \mathrm{C}\right.$ NMR (126 MHz, $\mathrm{CDCl}_{3}, 23$ $\left.{ }^{\circ} \mathrm{C}\right): \delta 31.81,36.88,50.72,120.80,126.50,127.82,128.90,129.56,129.75,132.43$, 143.46, 145.59, 146.89. The foregoing NMR data are taken from the spectra of the product/substrate mixture and only the peaks for the product are reported. HR-MS (+EI): Calc'd for: $\mathrm{C}_{15} \mathrm{H}_{12} \mathrm{ClBr}$, [M] ${ }^{++}, \mathrm{m} / \mathrm{z}$ 305.9808. Found $\mathrm{m} / \mathrm{z}$ 305.9812. Chiral separation was achieved using chiral SFC analysis (OJ-H, 40\% MeOH/CO $3.0 \mathrm{~mL} / \mathrm{mol}, 220 \mathrm{~nm})$. 


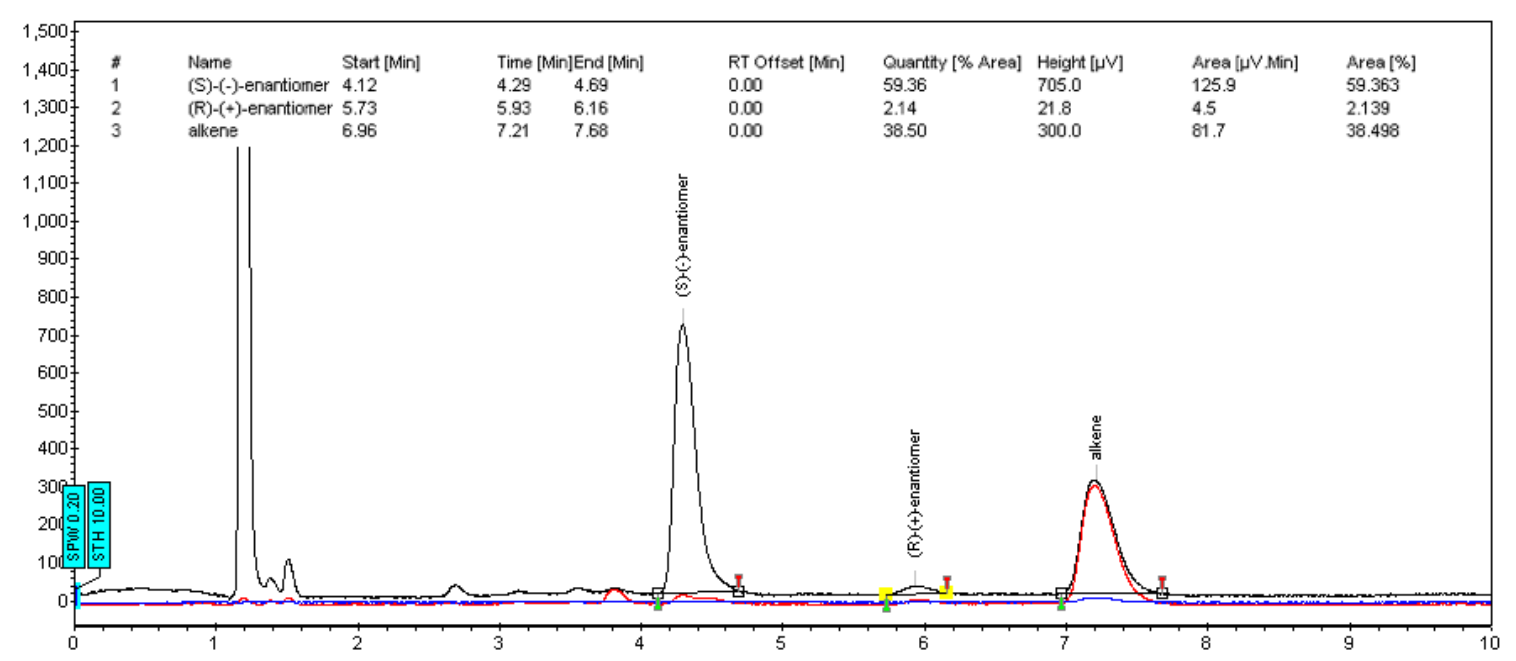

(S)-(+)-1-phenyltetralin (4a). Using Procedure A with $1.0 \mathrm{mmol}$ of 1-phenyl3,4-dihydronaphthalene $(3 \mathbf{a})$ and $0.5 \mathrm{~mL}$ toluene for 48 hours at $25^{\circ} \mathrm{C}, 4 \mathbf{a}$ was isolated as a clear oil in $94 \%$ yield $(0.196 \mathrm{~g})$ and $98 \%$ ee. $[\alpha]^{23}{ }_{D}=+14.5^{\circ}(c 0.5$, $\left.\mathrm{CHCl}_{3}\right),[\alpha]^{23}{ }_{\mathrm{D}}=+12.1^{\circ}\left(c 5, \mathrm{CHCl}_{3}\right) \cdot{ }^{37,38}{ }^{1} \mathrm{H} \mathrm{NMR}\left(500 \mathrm{MHz}, \mathrm{CDCl}_{3}, 23{ }^{\circ} \mathrm{C}\right): \delta 1.78(\mathrm{~m}$, 1H, 3-tetralin $\mathrm{CH}$ ), 1.84-1.95 (overlapping m, 2H, 2-tetralin $\mathrm{CH}$, 3-tetralin $\mathrm{CH}$ ), 2.14-2.22 (m, 1H, 2-tetralin $\mathrm{CH}$ ), 2.81-2.98 (m, overlapping $\mathrm{m}, 2 \mathrm{H}$, diastereotopic 4-tetralin $\mathrm{CH}$ ), $4.13\left(\mathrm{t},{ }^{3} \mathrm{~J}_{\mathrm{HH}}=6.8 \mathrm{~Hz}, 1 \mathrm{H}, 1\right.$-tetralin $\left.\mathrm{CH}\right), 6.85\left(\mathrm{~d},{ }^{3} \mathrm{~J}_{\mathrm{HH}}=7.7 \mathrm{~Hz}, 1 \mathrm{H}\right.$, aryl $\left.\mathrm{CH}\right), 7.04(\mathrm{~m}$, $1 \mathrm{H}$, aryl $\mathrm{CH}$ ), 7.09-7.16 (overlapping $\mathrm{m}, 4 \mathrm{H}$, aryl $\mathrm{CH}$, phenyl $\mathrm{CH}), 7.18-7.23(\mathrm{~m}, 1 \mathrm{H}$, aryl $\mathrm{CH}$ ), 7.27-7.31 (overlapping $\mathrm{m}, 2 \mathrm{H}$, aryl $\mathrm{CH}$, phenyl $\mathrm{CH}$ ). $\left\{{ }^{1} \mathrm{H}\right\}^{13} \mathrm{C} \mathrm{NMR}\left(126 \mathrm{MHz}, \mathrm{CDCl}_{3}\right.$, $\left.23{ }^{\circ} \mathrm{C}\right): \delta 21.18,30.00,33.47,45.83,125.83,126.09,126.14,128.42,129.05,129.16$, 130.39, 137.80, 139.58, 147.72. ${ }^{1} \mathrm{H}$ and ${ }^{13} \mathrm{C}$ NMR spectra are consistent with previously reported data. ${ }^{39}$ Chiral separation was achieved using chiral GC chromatography according to the following isothermal method: hold at $150 \stackrel{\circ}{\mathrm{C}}$ for 100 minutes; ramp 20 ${ }^{\circ} \mathrm{C}$ per minute, hold at $200{ }^{\circ} \mathrm{C}$ for 6 minutes. 


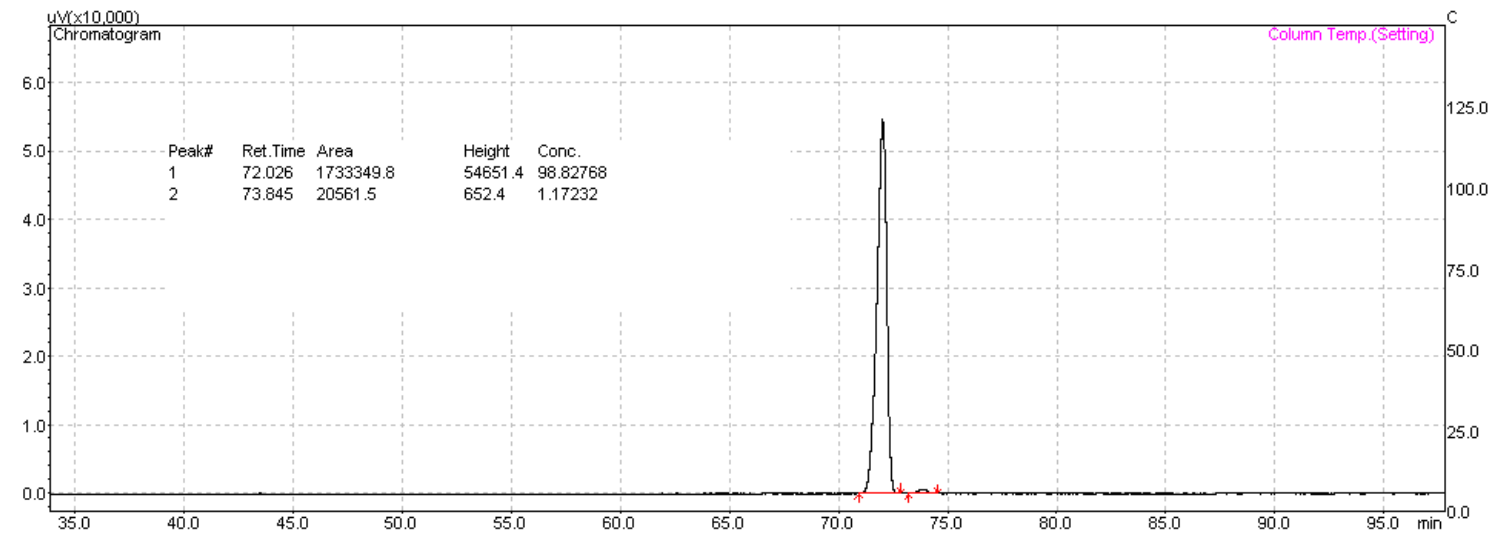

(S)-(+)-1-(p-methoxyphenyl)-tetralin 4b. Using Procedure A with $1.0 \mathrm{mmol}$ substrate $\mathbf{3 b}$ and $0.5 \mathrm{~mL}$ toluene, $\mathbf{4 b}$ was isolated as a white solid in $96 \%$ yield $(0.229 \mathrm{~g})$ and $98 \%$ ee. $[\alpha]^{23}{ }_{\mathrm{D}}=+17.6^{\circ}\left(\mathrm{c}\right.$ 5, $\left.\mathrm{CHCl}_{3}\right),[\alpha]_{\mathrm{D}}^{23}=+23.2^{\circ}(c$ 2.5, $\mathrm{MeOH}) \cdot{ }^{37}{ }^{1} \mathrm{H}$ NMR $\left(500 \mathrm{MHz}, \mathrm{CDCl}_{3}, 23^{\circ} \mathrm{C}\right): \delta$ 1.69-1.96 (overlapping $\mathrm{m}, 3 \mathrm{H}, 2-$ and 3tetralin $\mathrm{CH}_{2}$ ), 2.09-2.21 (m, 1H, diastereotopic 2-tetralin $\mathrm{CH}$ ), 2.78-2.98 (overlapping m, $2 \mathrm{H}$, diastereotopic 3-tetralin $\mathrm{CH}$ ), $3.80\left(\mathrm{~s}, 3 \mathrm{H}, \mathrm{OCH}_{3}\right), 4.08$ (apparent t, ${ }^{3} \mathrm{~J}_{\mathrm{HH}}=6.4 \mathrm{~Hz}$, 1H, 1-tetralin $\mathrm{CH}$ ), 6.80-6.88 (overlapping $\mathrm{m}, 3 \mathrm{H}$, aryl $\mathrm{CH}$, phenyl $\mathrm{CH}$ ), 6.99-7.07 (overlapping $\mathrm{m}, 3 \mathrm{H}$, aryl $\mathrm{CH}$, phenyl $\mathrm{CH}$ ), 7.11-7.15 (overlapping $\mathrm{m}, 2 \mathrm{H}$, aryl $\mathrm{CH}$ ). $\left\{{ }^{1} \mathrm{H}\right\}^{13} \mathrm{C}$ NMR $\left(126 \mathrm{MHz}^{\mathrm{CDCl}} \mathrm{CD}_{3}, 2{ }^{\circ} \mathrm{C}\right): \delta 21.16,29.99,33.54,44.94,55.43,113.79$, $125.79,126.01,129.13,129.89,130.32,137.72,139.86,139.93,157.98 .{ }^{1} \mathrm{H}$ and ${ }^{13} \mathrm{C}$ NMR spectra are consistent with previously reported data. ${ }^{40}$ Chiral separation was achieved using chiral GC chromatography according to the following isothermal method: hold at $170{ }^{\circ} \mathrm{C}$ for 120 minutes; ramp $20{ }^{\circ} \mathrm{C}$ per minute, hold at $200{ }^{\circ} \mathrm{C}$ for 6 minutes. 


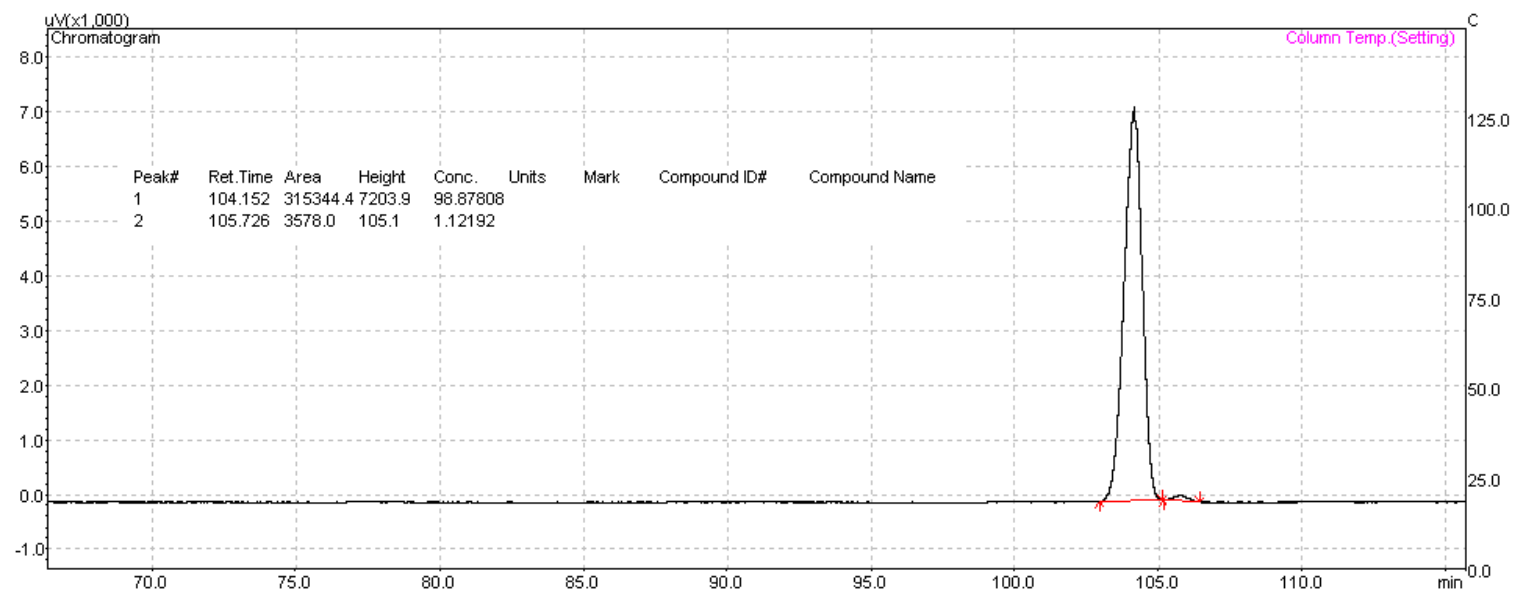

\section{(S)-(-)-1-isopropyl-6-methoxytetralin (6a). Using Procedure A with 1.0}

mmol of 1-isopropyl-6-methoxy-3,4-dihydronaphthalene (5a) and $0.5 \mathrm{~mL}$ toluene for 48 hours at $25^{\circ} \mathrm{C}, 6 \mathrm{a}$ was isolated as a clear oil in $96 \%$ yield $(0.197 \mathrm{~g})$ in $94 \%$ ee. $[\alpha]^{23}{ }_{\mathrm{D}}=-54.3^{\circ}\left(c\right.$ 1, $\left.\mathrm{CHCl}_{3}\right),[\alpha]^{23} \mathrm{D}=-58.4^{\circ}\left(c 5, \mathrm{CHCl}_{3}\right) \cdot{ }^{11}{ }^{1} \mathrm{H} \mathrm{NMR}(500 \mathrm{MHz}$, $\left.\mathrm{CDCl}_{3}, 23 \stackrel{\circ}{\circ}\right): \delta 0.73\left(\mathrm{~d},{ }^{3} \mathrm{~J}_{\mathrm{HH}}=6.8 \mathrm{~Hz}, 3 \mathrm{H}\right.$, diastereotopic iPr $\left.\mathrm{CH}_{3}\right), 1.00\left(\mathrm{~d},{ }^{3} \mathrm{~J}_{\mathrm{HH}}=6.8\right.$ $\mathrm{Hz}, 3 \mathrm{H}$, diastereotopic $\operatorname{Pr} \mathrm{CH}_{3}$ ), 1.56-1.66 (overlapping $\mathrm{m}$, 2-tetralin $\mathrm{CH}$, 3-tetralin $\mathrm{CH}$ ), 1.76-1.82 (m, 1H, 2-tetralin $\mathrm{CH}), 1.87-1.94(\mathrm{~m}, 1 \mathrm{H}, 3$-tetralin $\mathrm{CH}), 2.20(\mathrm{~m}, 1 \mathrm{H}, \mathrm{iPr} \mathrm{CH})$, 2.61-2.67 (m, 1H, 1-tetralin $\mathrm{CH}$ ), 2.68-2.76 (overlapping $\mathrm{m}, 2 \mathrm{H}$, diastereotopic 4-tetralin $\mathrm{CH}), 3.78\left(\mathrm{~s}, 3 \mathrm{H}, \mathrm{OCH} \mathrm{H}_{3}\right), 6.60\left(\mathrm{~d},{ }^{4} \mathrm{~J}_{\mathrm{HH}}=2.7 \mathrm{~Hz}, 1 \mathrm{H}, 5\right.$-tetralin $\left.\mathrm{CH}\right), 6.70\left(\mathrm{dd},{ }^{3} J_{\mathrm{HH}}=8.5\right.$ $\mathrm{Hz},{ }^{4} \mathrm{~J}_{\mathrm{HH}}=2.8 \mathrm{~Hz}, 1 \mathrm{H}, 7$-tetralin $\left.\mathrm{CH}\right), 7.12\left(\mathrm{~d},{ }^{3} \mathrm{~J}_{\mathrm{HH}}=8.5 \mathrm{~Hz}, 1 \mathrm{H}\right.$, 8-tetralin $\left.\mathrm{CH}\right) .\left\{{ }^{1} \mathrm{H}\right\}^{13} \mathrm{C}$ $\operatorname{NMR}\left(126 \mathrm{MHz}, \mathrm{CDCl}_{3}, 23^{\circ} \mathrm{C}\right): \delta 17.59,21.48,21.67,23.59,30.54,31.63,43.06,55.35$, 111.71, 113.60, 129.34, 132.76, 139.46, 157.25. ${ }^{1} \mathrm{H}$ and ${ }^{13} \mathrm{C}$ NMR spectra are consistent with previously reported data. ${ }^{11 E r r o r ! ~ B o o k m a r k ~ n o t ~ d e f i n e d . ~ C h i r a l ~ s e p a r a t i o n ~ w a s ~ a c h i e v e d ~}$ using chiral GC chromatography according to the following isothermal method: hold at $150 \stackrel{\circ}{ } \mathrm{C}$ for 90 minutes; ramp $20 \stackrel{\circ}{\mathrm{C}}$ per minute, hold at $200{ }^{\circ} \mathrm{C}$ for 6 minutes. 


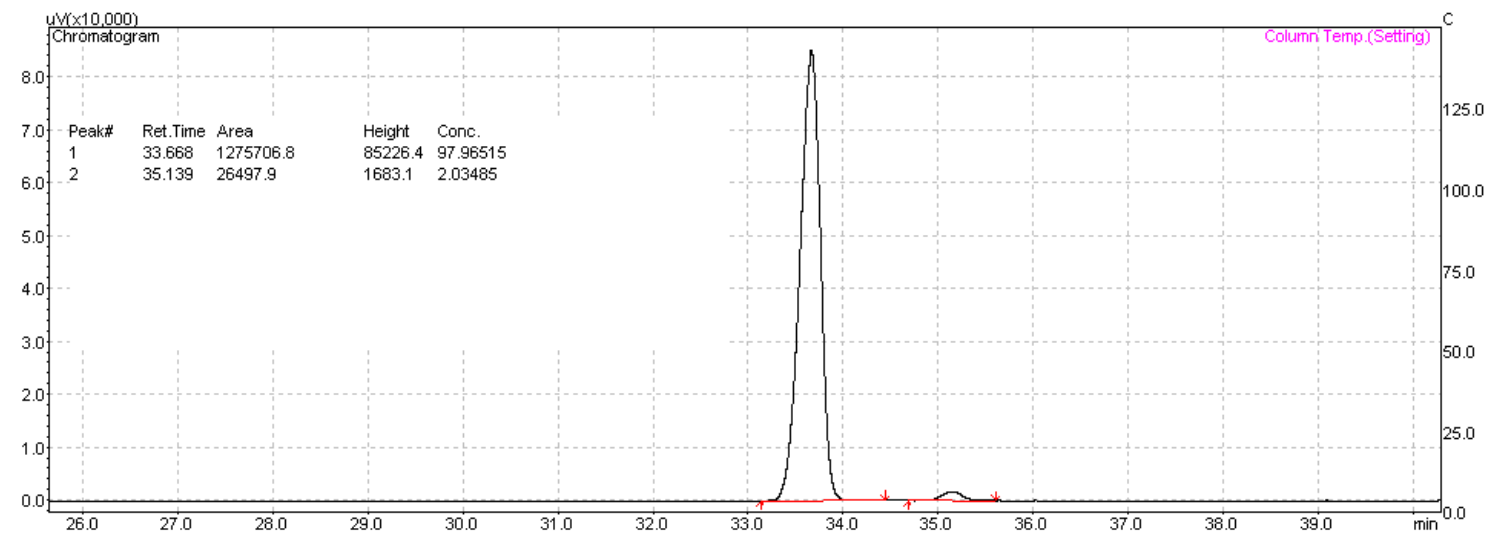

(S)-(+)-1-(4'-methoxyphenyl)-6-methoxy-tetralin (6b). Using Procedure

A with $1.0 \mathrm{mmol}$ substrate $(5 \mathrm{~b}), 1 \mathrm{~mL}$ toluene for 48 hours at $25^{\circ} \mathrm{C}, 6 \mathrm{~b}$ was isolated in $73 \%$ yield $(0.197 \mathrm{~g})$ and $92 \%$ ee following recrystallization from hexane at $-35 \stackrel{\circ}{\circ}$. The material contained $<5 \%$ of the substrate alkene. $[\alpha]^{23}{ }_{D}=+15.1^{\circ}$ (c 5, $\left.\mathrm{CHCl}_{3}\right) .{ }^{1} \mathrm{H}$ NMR $\left(500 \mathrm{MHz}, \mathrm{CDCl}_{3}, 23 \stackrel{\circ}{\circ}\right): \delta 1.74(\mathrm{~m}, 1 \mathrm{H}$, 3-tetralin $\mathrm{CH}), 1.81(\mathrm{~m}$, 1H, 2-tetralin $\mathrm{CH}), 1.88(\mathrm{~m}, 1 \mathrm{H}$, 3-tetralin $\mathrm{CH}), 2.12(\mathrm{~m}, 1 \mathrm{H}$, 2-tetralin $\mathrm{CH}), 2.81(\mathrm{~m}, 1 \mathrm{H}$, 4-tetralin $\mathrm{CH}), 2.89(\mathrm{~m}, 1 \mathrm{H}, 4$-tetralin $\mathrm{CH}), 3.78\left(\mathrm{~s}, 3 \mathrm{H}, \mathrm{OCH}_{3}\right), 3.79\left(\mathrm{~s}, 3 \mathrm{H}, \mathrm{OCH}_{3}\right), 4.01$ $(\mathrm{m}, 1 \mathrm{H}, 1$-tetralin $\mathrm{CH}), 6.62\left(\mathrm{dd},{ }^{3} \mathrm{~J}_{\mathrm{HH}}=8.5 \mathrm{~Hz},{ }^{4} \mathrm{~J}_{\mathrm{HH}}=2.7 \mathrm{~Hz}, 1 \mathrm{H}, 7\right.$-tetralin $\left.\mathrm{CH}\right), 6.66(\mathrm{~d}$, ${ }^{4} J_{\mathrm{HH}}=2.7 \mathrm{~Hz}, 1 \mathrm{H}, 5$-tetralin $\left.\mathrm{CH}\right), 6.67\left(\mathrm{~d},{ }^{3} \mathrm{~J}_{\mathrm{HH}}=8.5 \mathrm{~Hz}, 1 \mathrm{H}, 8\right.$-tetralin $\left.\mathrm{CH}\right), 6.82(\mathrm{~m}, 2 \mathrm{H}$, aryl $\mathrm{CH}), 7.01(\mathrm{~m}, 2 \mathrm{H}$, aryl $\mathrm{CH}) .\left\{{ }^{1} \mathrm{H}\right\}^{13} \mathrm{C}$ NMR $\left(126 \mathrm{MHz}, \mathrm{CDCl}_{3}, 23^{\circ} \mathrm{C}\right): \delta 21.16,30.35$, $33.74,44.27,55.38,112.22,113.38,113.76,129.80,131.29,132.18,138.89,140.08$, 157.73, 157.96. ${ }^{1} \mathrm{H}$ and ${ }^{13} \mathrm{C}$ NMR spectra are consistent with previously reported data. ${ }^{41}$ Chiral separation was achieved using chiral SFC analysis (AD-H, 5\%-50\% MeOH gradient $/ \mathrm{CO}_{2}, 3.0 \mathrm{~mL} / \mathrm{mol}, 220 \mathrm{~nm}$ ). 

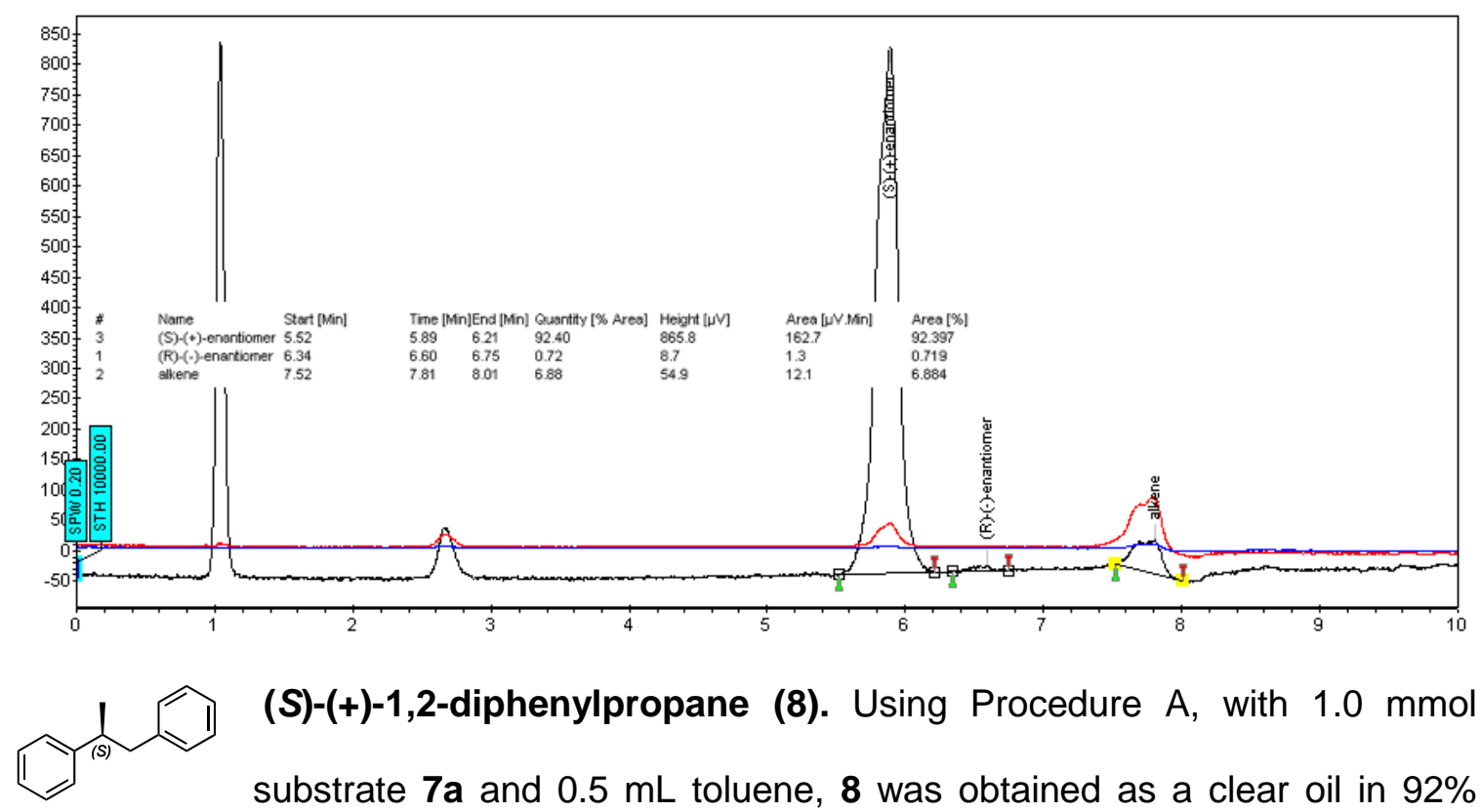

(S)-(+)-1,2-diphenylpropane (8). Using Procedure A, with $1.0 \mathrm{mmol}$ substrate $7 \mathrm{a}$ and $0.5 \mathrm{~mL}$ toluene, 8 was obtained as a clear oil in $92 \%$ yield $(0.180 \mathrm{~g})$ and $66 \%$ ee. $[\alpha]^{23}{ }_{\mathrm{D}}=+99.7^{\circ}(c 3$, dichloromethane $),[\alpha]^{23} \mathrm{D}=+48.4^{\circ}(c 5$, $\left.\mathrm{CHCl}_{3}\right)$ at $56 \%$ ee. Absolute configuration assigned in analogy to 1-phenyl-2-(4'methoxyphenyl)-propane. ${ }^{42}{ }^{1} \mathrm{H}$ NMR $\left(500 \mathrm{MHz}, \mathrm{CDCl}_{3}, 23^{\circ} \mathrm{C}\right): \delta 1.28\left(\mathrm{~d},{ }^{3} \mathrm{~J}_{\mathrm{HH}}=6.8 \mathrm{~Hz}\right.$, $\left.3 \mathrm{H}, \mathrm{CH}_{3}\right), 2.80\left(\mathrm{dd},{ }^{2} J_{\mathrm{HH}}=13.1 \mathrm{~Hz},{ }^{3} J_{\mathrm{HH}}=8.1 \mathrm{~Hz}\right.$, one diastereotopic signal from $\left.\mathrm{PhCH}_{2}\right)$, 2.96-3.08 (overlapping $\mathrm{m}, 2 \mathrm{H}$, one diastereotopic signal from $\mathrm{PhCH}_{2}, \mathrm{PhCHCH}_{2}$ ), 7.12 (m, 2H, Ph-CH), 7.18-7.24 (overlapping $\mathrm{m}, 4 \mathrm{H}, \mathrm{Ph}-\mathrm{CH}$ ), 7.25-7.34 (overlapping $\mathrm{m}, 4 \mathrm{H}$, $\mathrm{Ph}-\mathrm{CH}) .\left\{{ }^{1} \mathrm{H}\right\}^{13} \mathrm{C}$ NMR (126 MHz, $\left.\mathrm{CDCl}_{3}, 23^{\circ} \mathrm{C}\right): \delta$ 21.35, 42.07, 45.25, 126.03, 126.20, 127.24, 128.29, 128.49, 129.36, 141.01, 147.18. ${ }^{1} \mathrm{H}$ and ${ }^{13} \mathrm{C}$ NMR spectra are consistent with previously reported data. ${ }^{42,43}$ Chiral separation was achieved using chiral SFC analysis $\left(\mathrm{OJ}-\mathrm{H}, 10 \% \mathrm{MeOH} / \mathrm{CO}_{2}, 3.0 \mathrm{~mL} / \mathrm{mol}, 220 \mathrm{~nm}\right)$. 

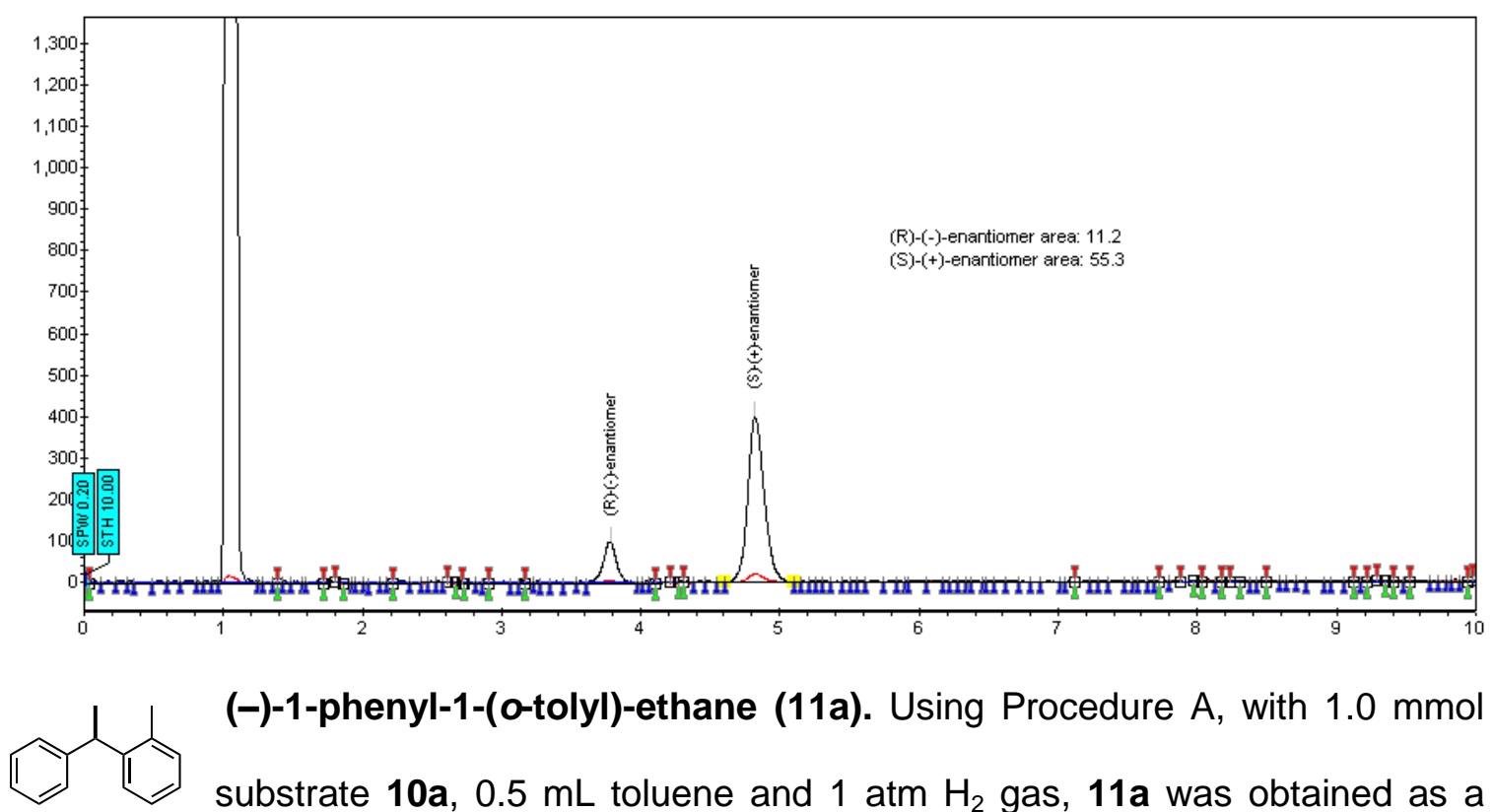

(-)-1-phenyl-1-(o-tolyl)-ethane (11a). Using Procedure A, with $1.0 \mathrm{mmol}$ substrate $10 \mathrm{a}, 0.5 \mathrm{~mL}$ toluene and $1 \mathrm{~atm} \mathrm{H}_{2}$ gas, 11a was obtained as a clear oil in $95 \%$ yield $(0.186 \mathrm{~g})$ and $76 \%$ ee. $[\alpha]^{23}{ }_{\mathrm{D}}=-27.1^{\circ}\left(\mathrm{c} 5, \mathrm{CHCl}_{3}\right)$ at $59 \%$ ee. ${ }^{1} \mathrm{H}$ $\operatorname{NMR}\left(500 \mathrm{MHz}, \mathrm{CDCl}_{3}, 23^{\circ} \mathrm{C}\right): \delta 1.63\left(\mathrm{~d},{ }^{3} \mathrm{~J}_{\mathrm{HH}}=7.6 \mathrm{~Hz}, 3 \mathrm{H}, \mathrm{CHCH}_{3}\right), 2.25(\mathrm{~s}, 3 \mathrm{H}$, $\left.\mathrm{ArCH}_{3}\right), 4.34\left(\mathrm{q},{ }^{3} \mathrm{~J}_{\mathrm{HH}}=7.2 \mathrm{~Hz}, 1 \mathrm{H}, \mathrm{CHCH}_{3}\right), 7.15(\mathrm{~m}, 2 \mathrm{H}$, aryl $\mathrm{CH}), 7.16-7.20$ (overlapping $\mathrm{m}, 3 \mathrm{H}$, aryl $\mathrm{CH}$ ), 7.20-7.24 $(\mathrm{m}, 1 \mathrm{H}$, aryl $\mathrm{CH}$ ), 7.26-7.31 (overlapping $\mathrm{m}, 3 \mathrm{H}$, aryl $\mathrm{CH}) \cdot\left\{{ }^{1} \mathrm{H}\right\}^{13} \mathrm{C}$ NMR $\left(126 \mathrm{MHz}, \mathrm{CDCl}_{3}, 23^{\circ} \mathrm{C}\right): \delta$ 19.98, 22.33, 41.19, 126.01, 126.21, 126.28, 126.86, 127.87, 128.50, 130.59. ${ }^{1} \mathrm{H}$ and ${ }^{13} \mathrm{C}$ NMR spectra are consistent with previously reported data. ${ }^{44}$ Chiral separation was achieved using chiral SFC analysis (OJ-H, 10\% iso-propanol/ $\mathrm{CO}_{2}, 3.0 \mathrm{~mL} / \mathrm{mol}, 220 \mathrm{~nm}$ ).

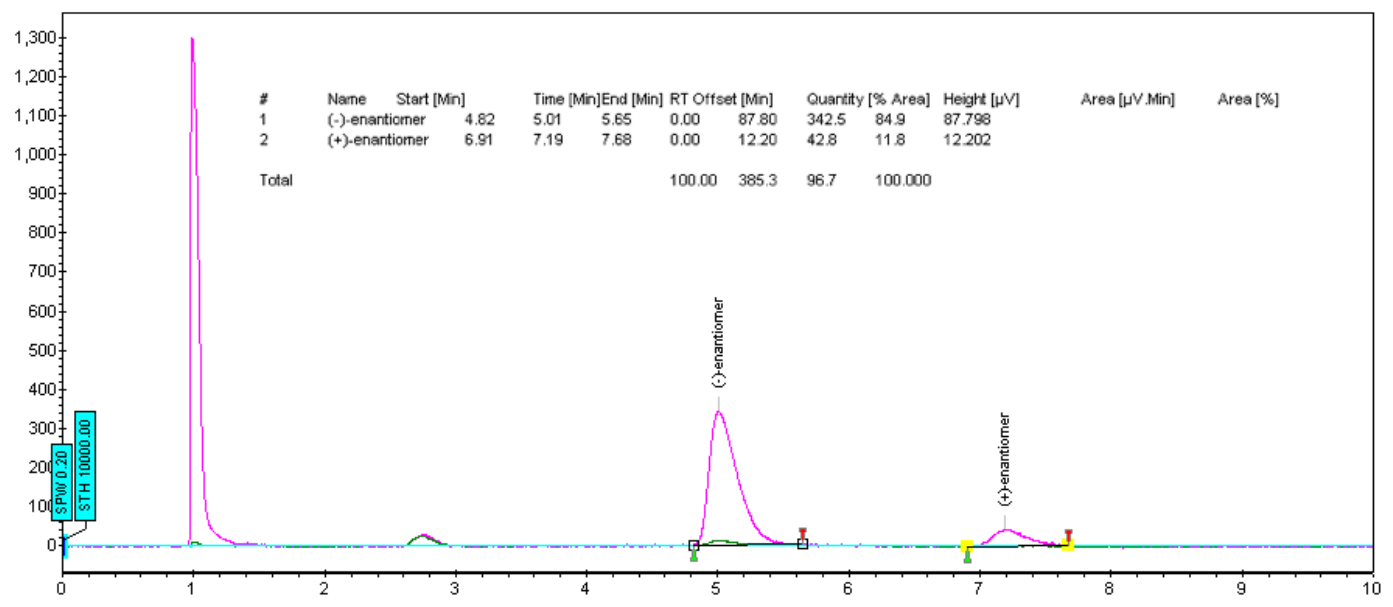




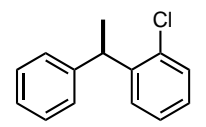

(+)-1-phenyl-1-(o-chlorophenyl)-ethane (11b). Using Procedure A, with $1.0 \mathrm{mmol}$ substrate $10 \mathrm{~b}, 0.5 \mathrm{~mL}$ toluene and 1 atm $\mathrm{H}_{2}$ gas, $11 \mathrm{~b}$ was obtained as a clear oil in $90 \%$ NMR yield (with the remainder of the material being the substrate alkene with $<1 \%$ of 1,1-diphenylethane arising from proto-dehalogenation) and $67 \%$ ee. $[\alpha]^{23} \mathrm{D}=+25.9^{\circ}$ (c 5 including unreacted alkene, $\left.\mathrm{CHCl}_{3}\right) \cdot{ }^{1} \mathrm{H} \mathrm{NMR}(500 \mathrm{MHz}$, $\left.\mathrm{CDCl}_{3}, 23 \stackrel{\circ}{\circ} \mathrm{C}\right): \delta 1.63\left(\mathrm{~d},{ }^{3} \mathrm{~J}_{\mathrm{HH}}=7.3 \mathrm{~Hz}, 3 \mathrm{H}, \mathrm{CHCH}_{3}\right), 4.67\left(\mathrm{q},{ }^{3} \mathrm{~J}_{\mathrm{HH}}=7.3 \mathrm{~Hz}, 1 \mathrm{H}, \mathrm{CHCH}_{3}\right)$, 7.11-7.39 (overlapping $\mathrm{m}, 9 \mathrm{H}$, phenyl and aryl $\mathrm{CH}$ ). $\left\{{ }^{1} \mathrm{H}\right\}^{13} \mathrm{C} \mathrm{NMR} \mathrm{(126} \mathrm{MHz,} \mathrm{CDCl}_{3}, 23$ $\left.{ }^{\circ} \mathrm{C}\right)$ : $\delta 21.35\left(\mathrm{CH}_{3}\right), 41.13(\mathrm{CH}), 126.35$ (phenyl $\mathrm{CH}$ ), 127.10 (aryl $\left.\mathrm{CH}\right), 127.52$ (aryl $\mathrm{CH}$ ), 127.97 (phenyl $\mathrm{CH}$ ), 128.53 (phenyl $\mathrm{CH}$ ), 128.77 (aryl $\mathrm{CH}$ ), 129.79 (aryl $\mathrm{CH}$ ), 134.07 (2aryl CCl), 143.86 (ipso C), 145.15 (ipso C). The foregoing NMR data are taken from the spectra of the product/substrate mixture and only the peaks for the product are reported. HR-MS (+EI): Calc'd for: $\mathrm{C}_{14} \mathrm{H}_{13} \mathrm{Cl},[\mathrm{M}]^{++}, \mathrm{m} / \mathrm{z}$ 216.07058. Found $\mathrm{m} / \mathrm{z}$ 216.0703. Chiral separation was achieved using chiral SFC analysis $\left(\mathrm{OJ}-\mathrm{H}, 5-50 \%\right.$ methanol/ $\mathrm{CO}_{2}$ gradient, $3.0 \mathrm{~mL} / \mathrm{mol}, 220 \mathrm{~nm}$ ).

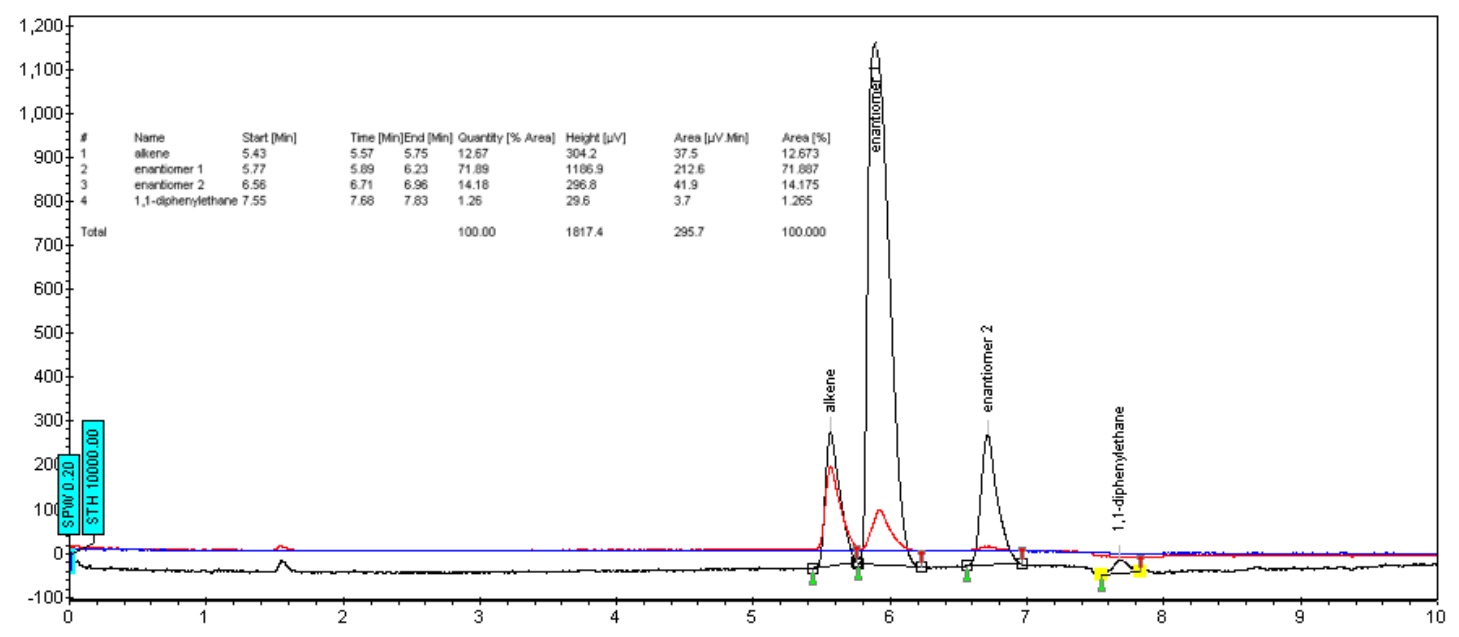

(+)-1-phenyl-1-(o-ethylphenyl)-ethane (11c). Using Procedure A, with 1.0 mmol substrate $10 \mathrm{c}, 0.5 \mathrm{~mL}$ toluene and $1 \mathrm{~atm} \mathrm{H}_{2}$ gas, $11 \mathrm{c}$ was obtained as a clear oil in $91 \%$ yield $(0.191 \mathrm{~g})$ and $77 \%$ ee. $[\alpha]^{23} \mathrm{D}=+2.4^{\circ}\left(\mathrm{c} 5, \mathrm{CHCl}_{3}\right) \cdot{ }^{1} \mathrm{H}$ NMR $(500$ $\left.\mathrm{MHz}, \mathrm{CDCl}_{3}, 23 \stackrel{\circ}{\mathrm{C}}\right): \delta 1.16\left(\mathrm{t},{ }^{3} \mathrm{~J}_{\mathrm{HH}}=7.5 \mathrm{~Hz}, 3 \mathrm{H}\right.$, ethyl $\left.\mathrm{CH}_{2} \mathrm{CH}_{3}\right), 1.63\left(\mathrm{~d},{ }^{3} \mathrm{~J}_{\mathrm{HH}}=7.1 \mathrm{~Hz}\right.$, 
$\left.3 \mathrm{H}, \mathrm{CHCH}_{3}\right), 2.56-2.65\left(\mathrm{~m}, 1 \mathrm{H}\right.$, diastereotopic ethyl $\left.\mathrm{CH}_{2} \mathrm{CH}_{3}\right), 2.66-2.76(\mathrm{~m}, 1 \mathrm{H}$, diastereotopic ethyl $\mathrm{CH}_{2} \mathrm{CH}_{3}$ ), 4.42 (q, ${ }^{3} \mathrm{~J}_{\mathrm{HH}}=7.2 \mathrm{~Hz}, 1 \mathrm{H}, \mathrm{CHCH}_{3}$ ), 7.15-7.23 (overlapping $\mathrm{m}, 6 \mathrm{H}$, phenyl and aryl $\mathrm{CH}$ ), 7.23-7.30 (overlapping $\mathrm{m}, 3 \mathrm{H}$, phenyl and aryl $\mathrm{CH}) \cdot\left\{{ }^{1} \mathrm{H}{ }^{13} \mathrm{C}\right.$ NMR $\left(126 \mathrm{MHz}, \mathrm{CDCl}_{3}, 23{ }^{\circ} \mathrm{C}\right): \delta 15.54$ (ethyl $\left.\mathrm{CH}_{2} \mathrm{CH}_{3}\right), 22.71\left(\mathrm{CHCH}_{3}\right)$, 25.81 (ethyl $\left.\mathrm{CH}_{2} \mathrm{CH}_{3}\right), 40.18\left(\mathrm{CHCH}_{3}\right), 125.99$ (phenyl $\mathrm{CH}$ ), 126.14 (aryl $\mathrm{CH}$ ), 126.44 (aryl $\mathrm{CH}$ ), $127.34(\operatorname{aryl} \mathrm{CH}), 127.83$ (phenyl $\mathrm{CH}), 128.48$ (phenyl $\mathrm{CH}), 128.79(\operatorname{aryl} \mathrm{CH})$, 141.97 (2-aryl CEt), 143.66 (ipso aryl C), 146.81 (ipso phenyl-C). HR-MS (+El): Calc'd for: $\mathrm{C}_{16} \mathrm{H}_{16},[\mathrm{M}]^{*+}, \mathrm{m} / \mathrm{z} 210.140850$. Found $m / z 210.1408$. Chiral separation was achieved using chiral SFC analysis (OD-H, 5-10\% iso-propanol/ $\mathrm{CO}_{2}$ gradient, $3.0 \mathrm{~mL} / \mathrm{mol}, 220$ $\mathrm{nm})$.

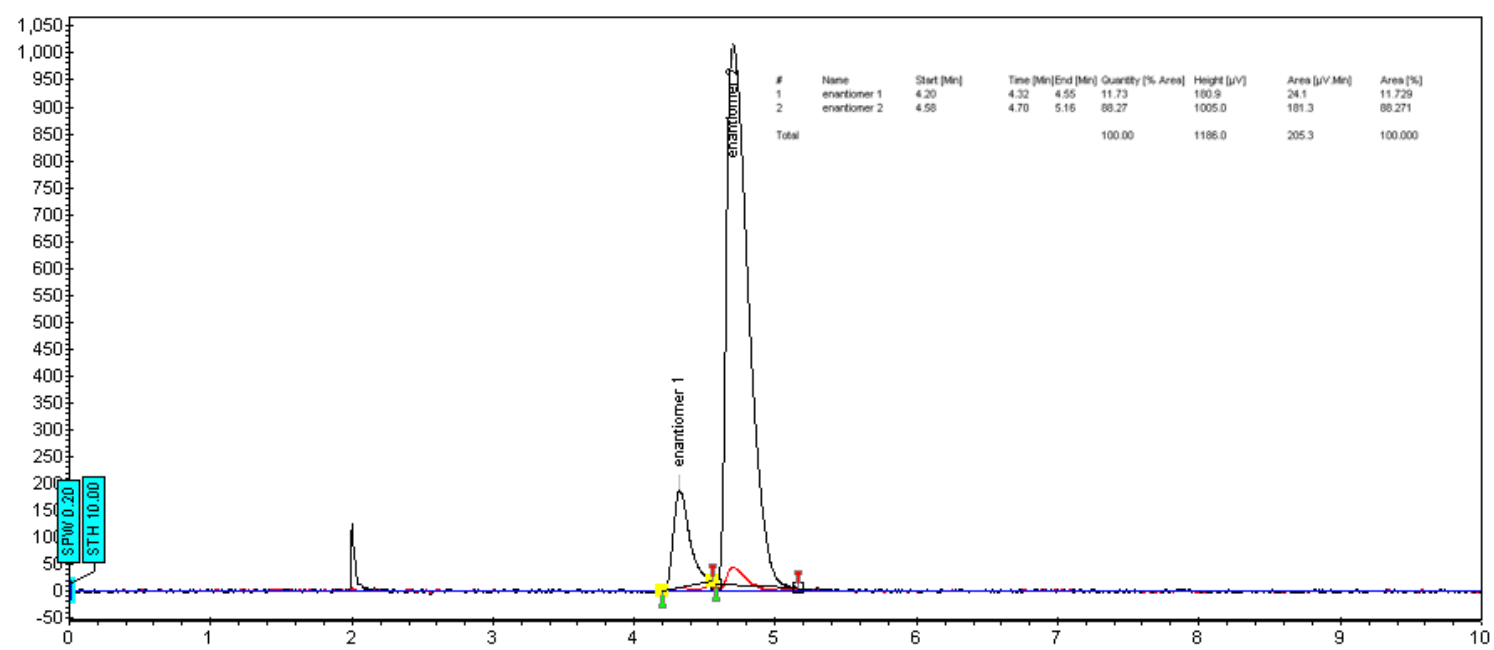

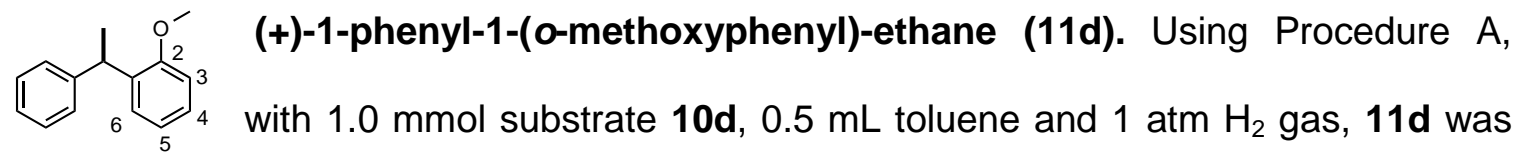
obtained as a clear oil in $94 \%$ yield $(0.200 \mathrm{~g})$ and $36 \%$ ee. $[\alpha]^{23} \mathrm{D}=+22.3^{\circ}\left(c 5, \mathrm{CHCl}_{3}\right)$. ${ }^{1} \mathrm{H}$ NMR $\left(500 \mathrm{MHz}, \mathrm{CDCl}_{3}, 23 \stackrel{\circ}{\circ} \mathrm{C}\right): \delta 1.59\left(\mathrm{~d},{ }^{3} \mathrm{JHH}_{\mathrm{H}}=7.2 \mathrm{~Hz}, 3 \mathrm{H}, \mathrm{CHCH}_{3}\right), 3.78(\mathrm{~s}, 3 \mathrm{H}$, $\left.\mathrm{OCH}_{3}\right), 4.58\left(\mathrm{q},{ }^{3} \mathrm{~J}_{\mathrm{HH}}=7.3 \mathrm{~Hz}, 1 \mathrm{H}, \mathrm{CHCH}_{3}\right), 6.85\left(\mathrm{~d},{ }^{3} \mathrm{~J}_{\mathrm{HH}}=8.1 \mathrm{~Hz}, 1 \mathrm{H}, 3-\operatorname{aryl} \mathrm{CH}\right), 6.91$ $\left(\mathrm{t},{ }^{3} \mathrm{JHH}_{\mathrm{HH}}=7.5 \mathrm{~Hz}, 1 \mathrm{H}, 5\right.$-aryl $\mathrm{CH}$ ), 7.14-7.20 (overlapping $\mathrm{m}, 3 \mathrm{H}$, phenyl and aryl $\mathrm{CH}$ ), 7.23-7.29 (overlapping m, 4H, phenyl and aryl CH). $\left\{{ }^{1} \mathrm{H}\right\}^{13} \mathrm{C}$ NMR $\left(126 \mathrm{MHz}, \mathrm{CDCl}_{3}, 23\right.$ 
$\left.{ }^{\circ} \mathrm{C}\right): \delta 21.10\left(\mathrm{CHCH}_{3}\right), 37.57\left(\mathrm{CHCH}_{3}\right), 55.63\left(\mathrm{OCH}_{3}\right), 110.76(\operatorname{aryl~} \mathrm{CH}), 12068$ (aryl $\left.\mathrm{CH}\right)$, 125.87 (aryl $\mathrm{CH}$ ), 127.24 (phenyl $\mathrm{CH}$ ), 127.84 (aryl $\mathrm{CH}$ ), 127.92 (phenyl $\mathrm{CH}$ ), 128.28 (phenyl $\mathrm{CH}$ ), 135.09 (ipso aryl C),146.57 (ipso phenyl C),157.00 (2-aryl $\mathrm{COCH}_{3}$ ). HR-MS (+EI): Calc'd for: $\mathrm{C}_{15} \mathrm{H}_{16} \mathrm{O},[\mathrm{M}]^{++}, \mathrm{m} / \mathrm{z} 212.12012$. Found $m / z$ 212.1201. Chiral separation was achieved using chiral SFC analysis $\left(\mathrm{OJ}-\mathrm{H}, 20 \%\right.$ methanol $/ \mathrm{CO}_{2}$ gradient, $3.0 \mathrm{~mL} / \mathrm{mol}$, $220 \mathrm{~nm})$.
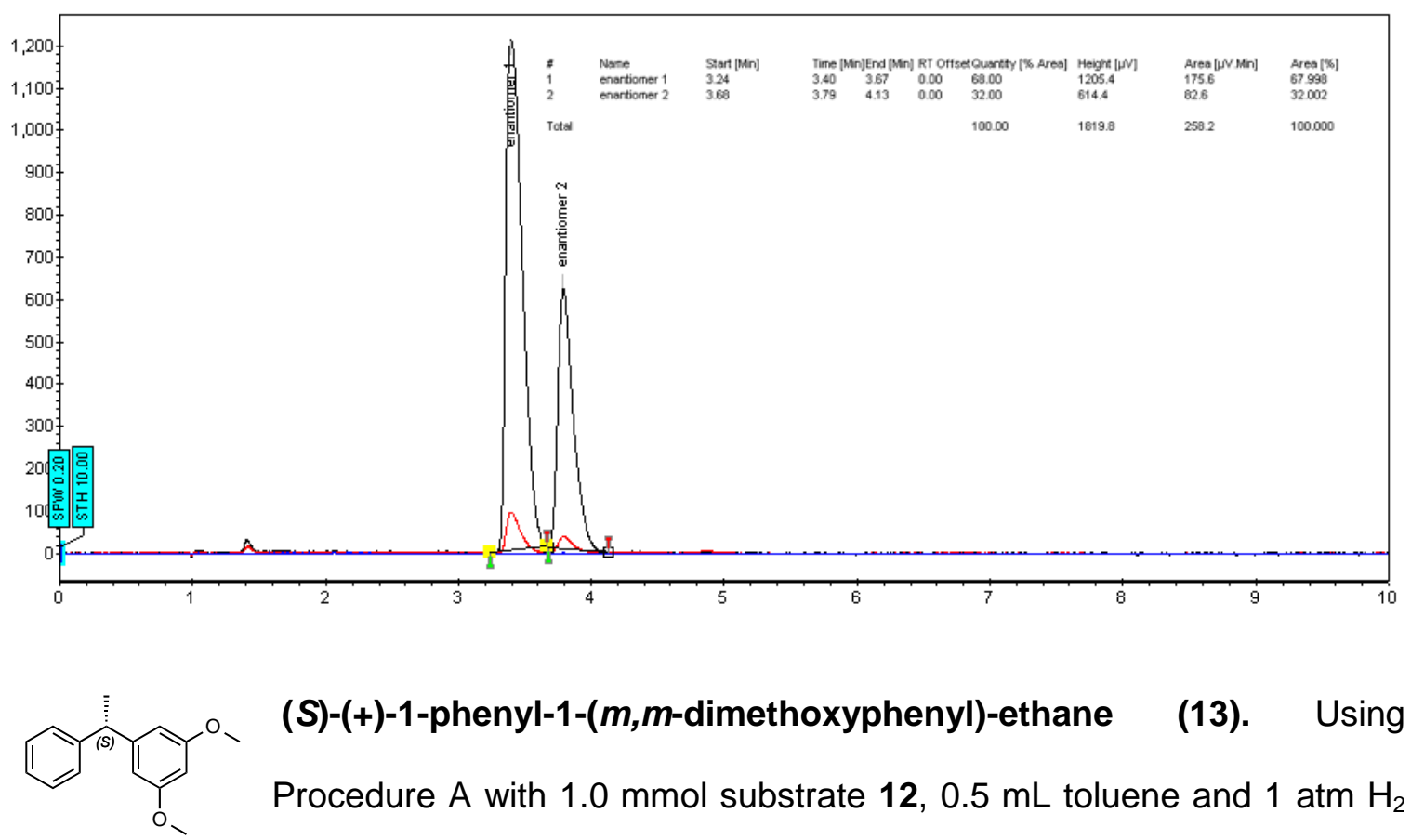

(S)-(+)-1-phenyl-1-(m,m-dimethoxyphenyl)-ethane

(13). Using

Procedure A with $1.0 \mathrm{mmol}$ substrate $12,0.5 \mathrm{~mL}$ toluene and $1 \mathrm{~atm} \mathrm{H}_{2}$ gas, 10 was isolated as a clear oil in $94 \%$ yield $(0.228 \mathrm{~g})$ and $27 \%$ ee. $[\alpha]^{23} \mathrm{D}=+0.5^{\circ}(\mathrm{c}$ 5, $\left.\mathrm{CHCl}_{3}\right) .{ }^{1} \mathrm{H} \mathrm{NMR}\left(500 \mathrm{MHz}, \mathrm{CDCl}_{3}, 23 \stackrel{\circ}{\circ} \mathrm{C}\right): \delta 1.62\left(\mathrm{~d},{ }^{3} \mathrm{JHH}_{\mathrm{HH}}=7.2 \mathrm{~Hz}, 3 \mathrm{H}, \mathrm{CHCH}_{3}\right), 3,75$ (s, $\left.6 \mathrm{H}, \mathrm{OCH}_{3}\right), 4.08\left(\mathrm{q},{ }^{3} \mathrm{JHH}_{\mathrm{HH}}=7.2 \mathrm{~Hz}, 1 \mathrm{H}, \mathrm{CHCH}_{3}\right), 6.30\left(\mathrm{t},{ }^{4} \mathrm{~J}_{\mathrm{HH}}=2.1 \mathrm{~Hz}, 1 \mathrm{H}, p\right.$-aryl-CH), $6.39\left(\mathrm{t},{ }^{4} \mathrm{~J}_{\mathrm{HH}}=2.1 \mathrm{~Hz}, 2 \mathrm{H}, o\right.$-aryl-CH), $7.18\left(\mathrm{tt},{ }^{3} \mathrm{JHH}_{\mathrm{HH}}=7.2 \mathrm{~Hz},{ }^{4} \mathrm{~J}_{\mathrm{HH}}=1.4 \mathrm{~Hz}, 1 \mathrm{H}, p\right.$-phenyl $\mathrm{CH})$, 7.22-7.25 (m, 2H, phenyl $\mathrm{CH}), 7.26-7.30(\mathrm{~m}, 2 \mathrm{H}$, phenyl $\mathrm{CH}) \cdot\left\{{ }^{1} \mathrm{H}\right\}^{13} \mathrm{C}$ NMR (126 $\left.\mathrm{MHz}, \mathrm{CDCl}_{3}, 23{ }^{\circ} \mathrm{C}\right): \delta 21.95,45.20,55.44,97.82,106.20,126.28,127.72,128.56$, 146.20, 149.03, 160.88. ${ }^{1} \mathrm{H}$ and ${ }^{13} \mathrm{C}$ NMR spectra are consistent with previously reported data. ${ }^{15}$ Chiral separation was achieved using chiral SFC analysis (AD-H, 5\%-25\% methanol gradient $/ \mathrm{CO}_{2}, 3.0 \mathrm{~mL} / \mathrm{mol}, 220 \mathrm{~nm}$ ). 


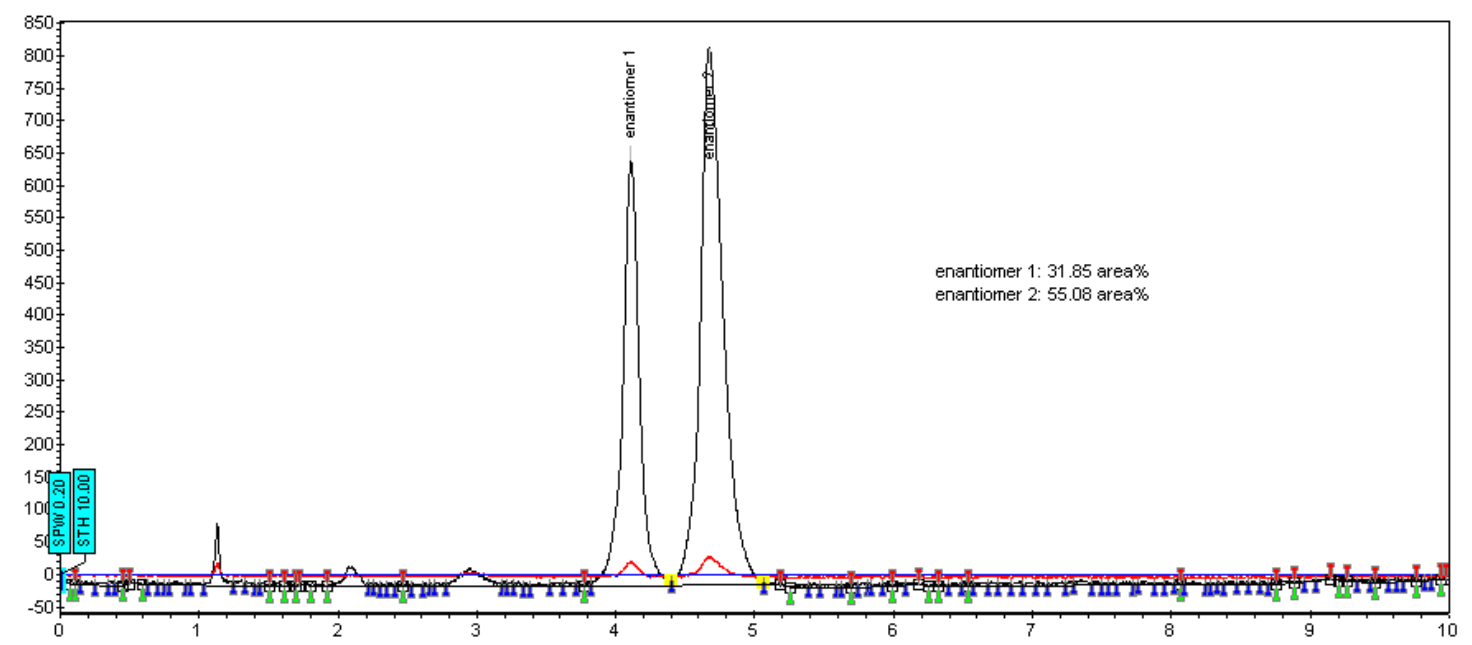

1-(2'-naphthyl)-1-(m,m,p-trimethoxyphenyl)-ethane (15). Using

Procedure A with $1.0 \mathrm{mmol}$ substrate $14,0.5 \mathrm{~mL}$ toluene and $1 \mathrm{~atm}$

$\mathrm{H}_{2}$ gas, 15 was isolated as a clear semi-solid followed by washing with $-35 \stackrel{\circ}{\circ} \mathrm{C}$ hexane in $51 \%$ yield and $<4 \%$ ee. ${ }^{1} \mathrm{H}$ NMR $\left(500 \mathrm{MHz}, \mathrm{CDCl}_{3}, 23^{\circ} \mathrm{C}\right): \delta 1.72$ $\left(\mathrm{d},{ }^{3} \mathrm{JHH}_{\mathrm{HH}}=7.2 \mathrm{~Hz}, 3 \mathrm{H}, \mathrm{CHCH}_{3}\right), 3.80\left(\mathrm{~s}, 6 \mathrm{H}, m-\mathrm{OCH}_{3}\right), 3.88\left(\mathrm{~s}, 3 \mathrm{H}, p-\mathrm{OCH}_{3}\right), 4.25\left(\mathrm{q},{ }^{3} J_{\mathrm{HH}}\right.$ $\left.=7.2 \mathrm{~Hz}, 1 \mathrm{H}, \mathrm{CHCH}_{3}\right), 6.48(\mathrm{~s}, 2 \mathrm{H}$, o-phenyl $\mathrm{CH}), 7.33\left(\mathrm{~d},{ }^{3} \mathrm{~J}_{\mathrm{HH}}=8.5 \mathrm{~Hz}, 1 \mathrm{H}, 3-\right.$ or 4naphthyl $\mathrm{CH}$ ), 7.45 (overlapping m, 2H 5-, 8-naphthyl $\mathrm{CH}$ ), 7.69 (s, 1H, 1-naphthyl $\mathrm{CH}$ ), $7.76\left(\mathrm{~d},{ }^{3} \mathrm{~J}_{\mathrm{HH}}=8.5 \mathrm{~Hz}, 1 \mathrm{H}, 3\right.$ - or 4-naphthyl $\left.\mathrm{CH}\right), 7.81$ (overlapping m, 2H, 6-, 7-naphthyl $\mathrm{CH}) \cdot\left\{{ }^{1} \mathrm{H}\right\}^{13} \mathrm{C}$ NMR $\left(126 \mathrm{MHz}, \mathrm{CDCl}_{3}, 23{ }^{\circ} \mathrm{C}\right): \delta 22.21\left(\mathrm{CHCH}_{3}\right), 45.30\left(\mathrm{CHCH}_{3}\right), 56.29$ (m-phenyl $\mathrm{OCH}_{3}$ ), 61.06 (p-phenyl $\mathrm{OCH}_{3}$ ), 105.00, 125.43, 125.63, 126.18, 126.87, $127.78,127.94,128.16,132.31,133.69,136.45,142.12,143.79,153.30 .{ }^{1} \mathrm{H}$ and ${ }^{13} \mathrm{C}$ NMR spectra are consistent with previously reported data. ${ }^{45}$ Chiral separation was achieved using chiral SFC analysis (AD-H, 20\% MeOH/CO $3.0 \mathrm{~mL} / \mathrm{mol}, 220 \mathrm{~nm})$. 


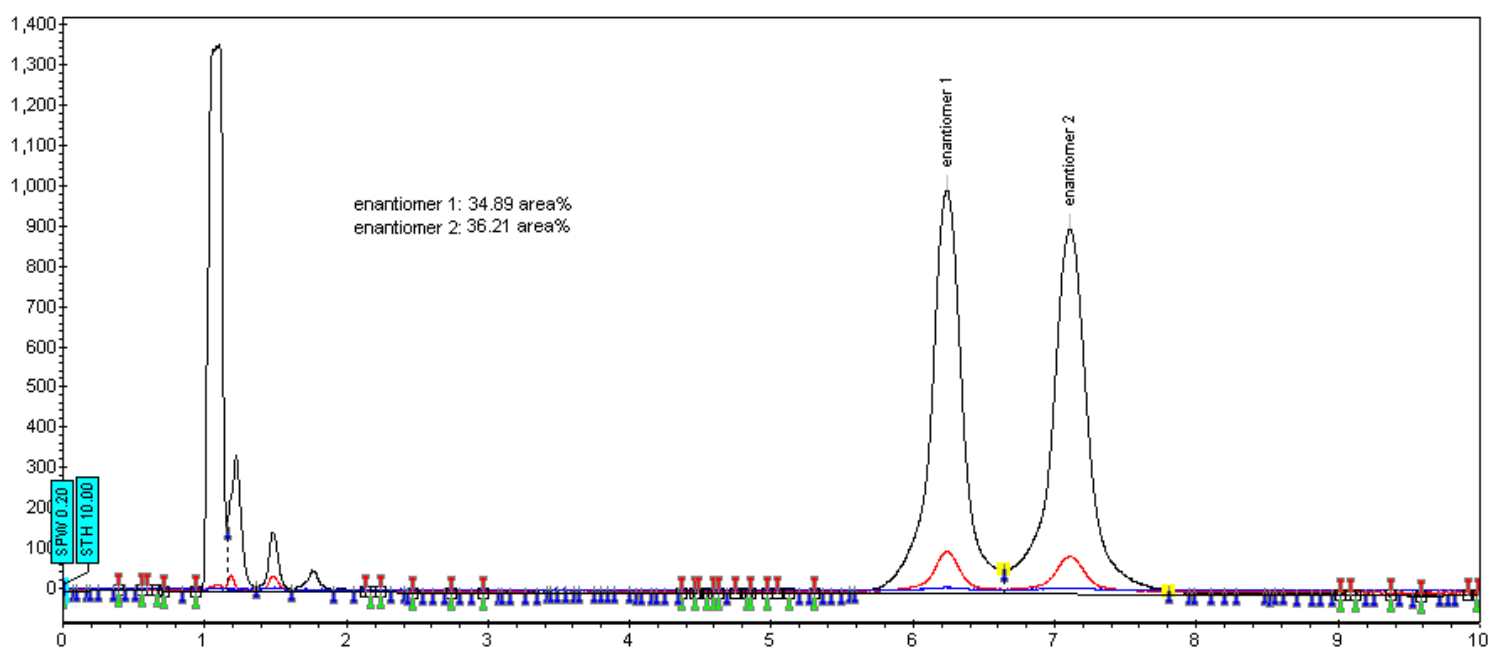

Me (S)-(-)-1-methylbenzosuberan (17). Using Procedure A with $1.0 \mathrm{mmol}$ substrate 16a and $4 \mathrm{~mL}$ diethyl ether, (S)-17 was isolated as a clear oil in $97 \%$ yield $(0.156 \mathrm{~g})$ and $85 \%$ ee. $[\alpha]^{23}{ }_{\mathrm{D}}=-9.4^{\circ}\left(c 5, \mathrm{CHCl}_{3}\right)$. Absolute configuration was assigned in analogy to 1 -methylindane and 1-methyltetralin. ${ }^{1} \mathrm{H} \mathrm{NMR}\left(500 \mathrm{MHz}, \mathrm{CDCl}_{3}\right.$, $\left.23{ }^{\circ} \mathrm{C}\right): \delta 1.34\left(\mathrm{~d},{ }^{3} \mathrm{~J}_{\mathrm{HH}}=7.1 \mathrm{~Hz}, 3 \mathrm{H}, \mathrm{CH}_{3}\right.$ ), 1.38-1.50 (overlapping $\mathrm{m}, 2 \mathrm{H}$ alkyl $\mathrm{CH}$ ), $1.69-$ 1.85 (overlapping $\mathrm{m}, 3 \mathrm{H}$, alkyl $\mathrm{CH}), 1.88-1.96(\mathrm{~m}, 1 \mathrm{H}$, alkyl $\mathrm{CH}), 2.75-2.83(\mathrm{~m}, 1 \mathrm{H}, 5-$ benzosuberan $\mathrm{CH}), 2.84-2.93(\mathrm{~m}, 1 \mathrm{H}$, 5-benzosuberan $\mathrm{CH}), 3.01-3.09(\mathrm{~m}, 1 \mathrm{H}, 1-$ benzosuberan $\mathrm{CH}$ ), 7.07-7.12 (overlapping $\mathrm{m}, 2 \mathrm{H}$, aryl $\mathrm{CH}$ ), 7.13-7.21 (overlapping , $2 \mathrm{H}$, aryl $\mathrm{CH}) \cdot\left\{{ }^{1} \mathrm{H}\right\}^{13} \mathrm{C}$ NMR $\left(126 \mathrm{MHz}, \mathrm{CDCl}_{3}, 23^{\circ} \mathrm{C}\right): \delta$ 20.65, 28.02, 36.29, 36.36, 125.88, $126.18,129.45,143.06,146.74$ (some carbon resonances not detected due to coincidental overlap). ${ }^{1} \mathrm{H}$ and ${ }^{13} \mathrm{C}$ NMR spectra are consistent with previously reported data. ${ }^{46}$ Chiral separation was achieved using chiral GC chromatography according to the following isothermal method: hold at $120{ }^{\circ} \mathrm{C}$ for 30 minutes; ramp $20 \stackrel{\circ}{ } \mathrm{C}$ per minute, hold at $200{ }^{\circ} \mathrm{C}$ for 6 minutes. 


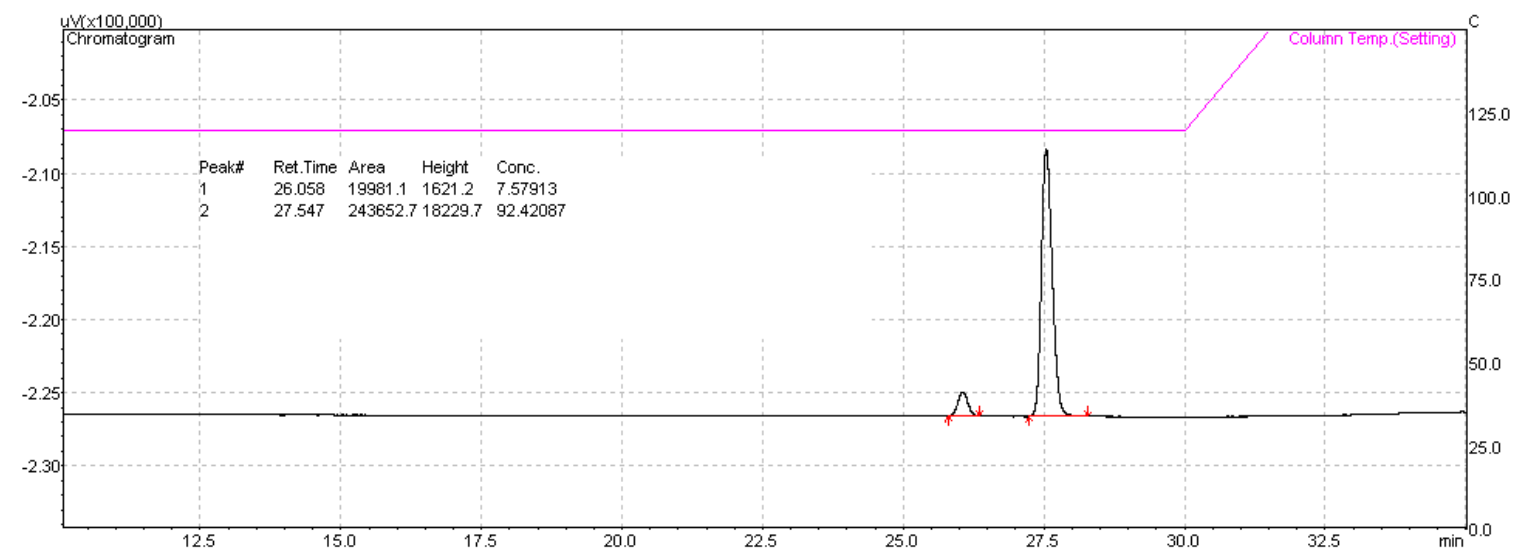

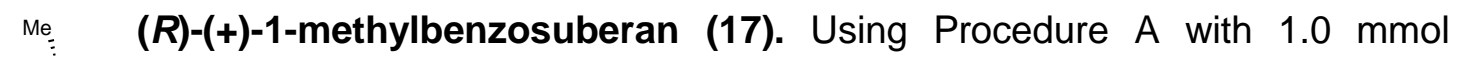
substrate $16 \mathrm{~b}$ and $4 \mathrm{~mL}$ diethyl ether, $(R)-17$ was isolated as a clear oil in $95 \%$ yield $(0.153 \mathrm{~g})$ and $89 \%$ ee. $[\alpha]^{23}{ }_{\mathrm{D}}=+10.0^{\circ}\left(\mathrm{c} 5, \mathrm{CHCl}_{3}\right)$. Absolute configuration was assigned in analogy to 1-methylindane and 1-methyltetralin. NMR spectra are consistent with the opposite enantiomer and previously reported data. ${ }^{46}$ Chiral separation was achieved using chiral GC chromatography according to the following isothermal method: hold at $120^{\circ} \mathrm{C}$ for 30 minutes; ramp $20^{\circ} \mathrm{C}$ per minute, hold at $200^{\circ} \mathrm{C}$ for 6 minutes.

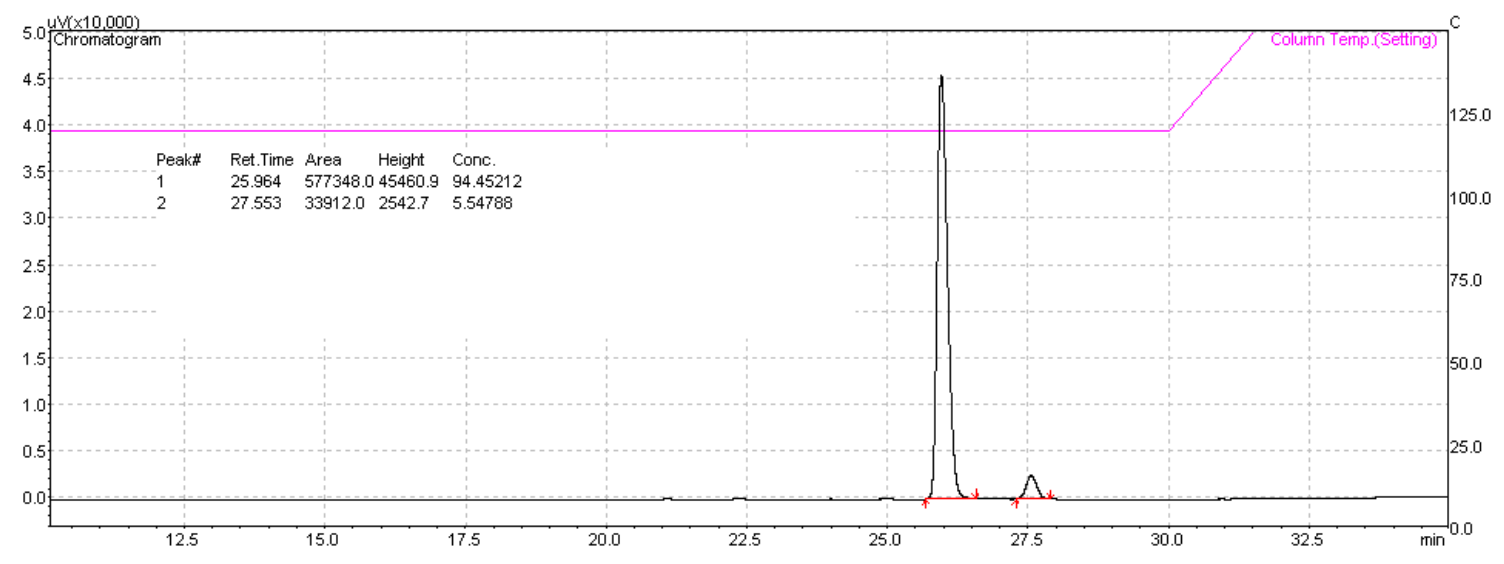

(S)-(+)-1-methyltetralin (19). Using Procedure A with $1.0 \mathrm{mmol}$ of 1 methylene-tetralin 18a and $4 \mathrm{~mL}$ diethyl ether, (S)-19 was isolated as a clear oil in $87 \%$ yield $(0.127 \mathrm{~g})$ and $53 \%$ ee. $[\alpha]^{23} \mathrm{D}=+11.4^{\circ}\left(\mathrm{c} 5, \mathrm{CHCl}_{3}\right) .{ }^{1} \mathrm{H} \mathrm{NMR}(500 \mathrm{MHz}$, $\left.\mathrm{CDCl}_{3}, 23 \stackrel{\circ}{\circ}\right): \delta 1.33\left(\mathrm{~d}, 3 \mathrm{H},{ }^{3} \mathrm{~J}_{\mathrm{HH}}=7.1 \mathrm{~Hz}, 3 \mathrm{H}, \mathrm{CH}_{3}\right), 1.58(\mathrm{~m}, 1 \mathrm{H}$, pro-S 2-tetralin $\mathrm{CH})$, 
$1.78(\mathrm{~m}, 1 \mathrm{H}$, pro-S 3-tetralin $\mathrm{CH}), 1.91(\mathrm{~m}, 1 \mathrm{H}$, pro- $R$ 3-tetralin $\mathrm{CH}), 1.97(\mathrm{~m}, 1 \mathrm{H}$, pro- $R$ 2-tetralin $\mathrm{CH}$ ), 2.74-2.87 (overlapping $\mathrm{m}, 2 \mathrm{H}$, diastereotopic 4-tetralin $\mathrm{CH}), 2.95(\mathrm{~m}, 1 \mathrm{H}$, 1-tetralin $\mathrm{CH}$ ), 7.08-7.15 (overlapping $\mathrm{m}, 2 \mathrm{H}$, aryl $\mathrm{CH}$ ), $7.17\left(\mathrm{t},{ }^{3} \mathrm{H}_{\mathrm{HH}}=7.5 \mathrm{~Hz}, 1 \mathrm{H}\right.$, aryl $\mathrm{CH}), 7.24(\mathrm{~m}, 1 \mathrm{H}$, aryl $\mathrm{CH})$. See Section $\mathrm{V}$ for determination of diastereotopic aliphatic $\mathrm{CH}$ resonances. $\left\{{ }^{1} \mathrm{H}\right\}^{13} \mathrm{C}$ NMR $\left(126 \mathrm{MHz}, \mathrm{CDCl}_{3}, 23^{\circ} \mathrm{C}\right)$ : $\delta 23.08\left(\mathrm{CH}_{3}\right), 20.67$ (3-tetralin $\mathrm{CH}_{2}$ ), 30.18 (4-tetralin $\mathrm{CH}_{2}$ ), 31.67 (2-tetralin $\mathrm{CH}_{2}$ ), 32.65 (1-tetralin $\mathrm{CHCH}_{3}$ ), 125.58 (7tetralin $\mathrm{CH}$ ), 125.79 (6-tetralin $\mathrm{CH}$ ), 128.28 (8-tetralin $\mathrm{CH}$ ), 129.20 (5-tetralin $\mathrm{CH}$ ), 137.05 (4a tetralin $\mathrm{C}$ ), 142.35 (8a tetralin $\mathrm{C}$ ). ${ }^{1} \mathrm{H}$ and ${ }^{13} \mathrm{C}$ NMR spectra are consistent with previously reported data. ${ }^{47,}{ }^{48}$ Chiral separation was achieved using chiral GC chromatography according to the following isothermal method: hold at $90{ }^{\circ} \mathrm{C}$ for 75 minutes; ramp $20 \stackrel{\circ}{\mathrm{C}}$ per minute, hold at $200^{\circ} \mathrm{C}$ for 6 minutes.

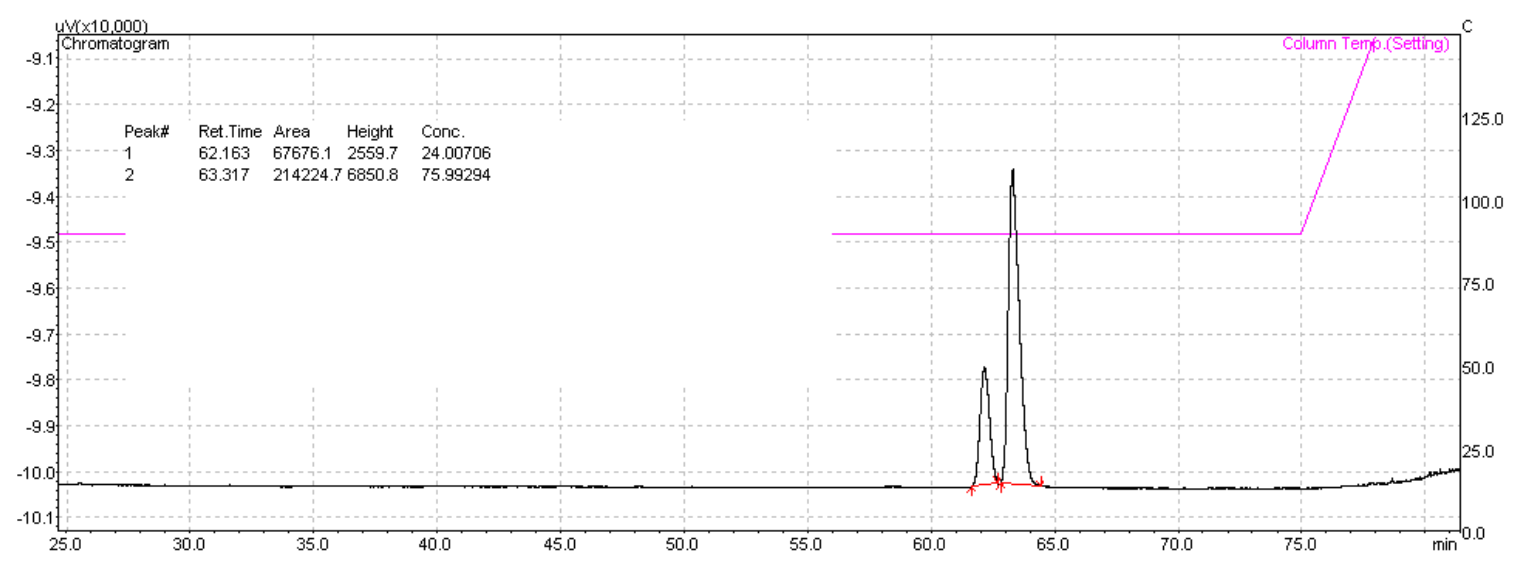

(R)-(-)-1-methyltetralin (19). Using Procedure A with $1.0 \mathrm{mmol}$ of 1-methyl-

3,4-dihydronaphthalene $\mathbf{1 8 b}$ and $4 \mathrm{~mL}$ diethyl ether, $(\boldsymbol{R})-\mathbf{1 9}$ was isolated as a clear oil in $88 \%$ yield $(0.129 \mathrm{~g})$ and $95 \%$ ee. $[\alpha]^{23} \mathrm{D}=-11.2^{\circ}\left(c 5, \mathrm{CHCl}_{3}\right),[\alpha]^{23} \mathrm{D}=-17.8^{\circ}$ (c 2.75, 1,4-dioxane). ${ }^{1} \mathrm{H}$ and ${ }^{13} \mathrm{C}$ NMR spectra are consistent with previously reported data. ${ }^{47,48}$ Chiral separation was achieved using chiral GC chromatography according to the following isothermal method: hold at $90{ }^{\circ} \mathrm{C}$ for 75 minutes; ramp $20{ }^{\circ} \mathrm{C}$ per minute, hold at $200{ }^{\circ} \mathrm{C}$ for 6 minutes. 


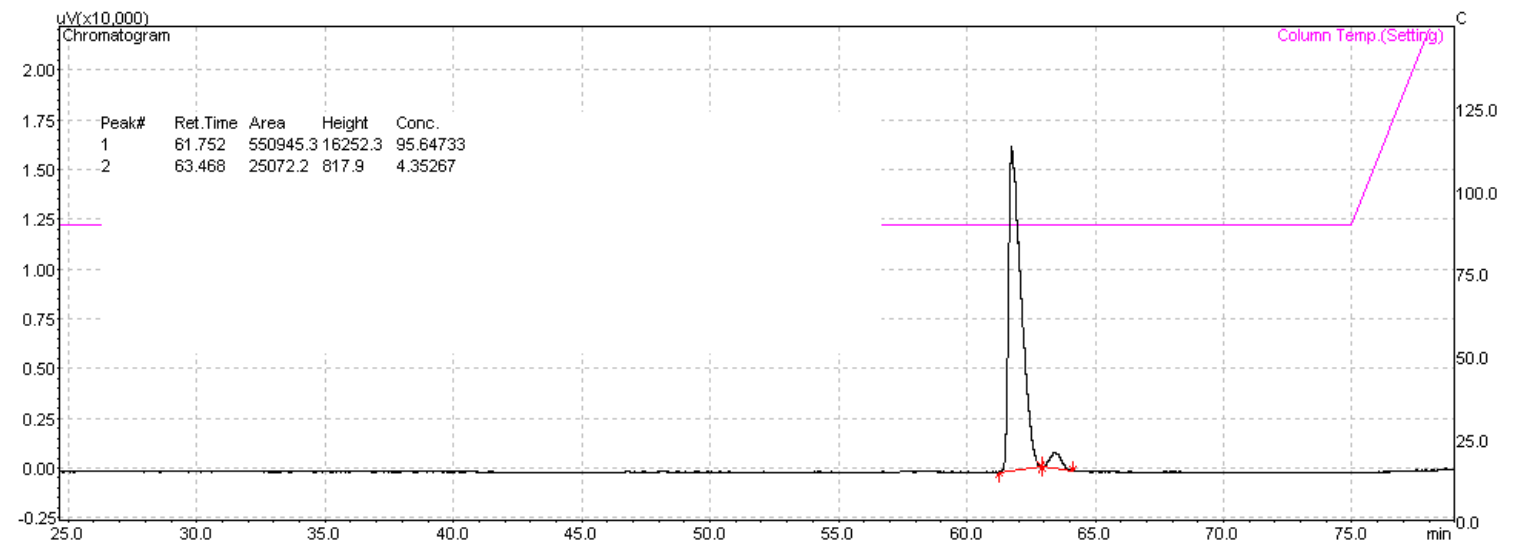

(R)-(+)-1-methylindane (21). Using Procedure A with $1.0 \mathrm{mmol}$ substrate $20 \mathrm{a}$, $4 \mathrm{~mL}$ diethyl ether, and 1 atm hydrogen, 21 was isolated as a clear oil in $84 \%$ yield $(0.111 \mathrm{~g})$ and $74 \%$ ee. $[\alpha]^{23}{ }_{\mathrm{D}}=+8.9^{\circ}\left(c 2.1, \mathrm{C}_{6} \mathrm{H}_{6}\right){ }^{49}[\alpha]^{23} \mathrm{D}=+2.5^{\circ}\left(c 5, \mathrm{CHCl}_{3}\right)$ at $79 \%$ ee. ${ }^{1} \mathrm{H}$ NMR $\left(500 \mathrm{MHz}, \mathrm{CDCl}_{3}, 23{ }^{\circ} \mathrm{C}\right): \delta 1.31\left(\mathrm{~d},{ }^{3} \mathrm{~J}_{\mathrm{HH}}=6.9 \mathrm{~Hz}, 3 \mathrm{H}, \mathrm{CH}_{3}\right), 1.62(\mathrm{~m}$, $1 \mathrm{H}$, pro- $R$ 2-indanyl $\mathrm{CH}), 2.33(\mathrm{~m}, 1 \mathrm{H}$, pro-S 2-indanyl $\mathrm{CH}), 2.81-2.89(\mathrm{~m}$, pro- $R$ 3indanyl $\mathrm{CH}), 2.89-2.96(\mathrm{~m}, 1 \mathrm{H}$, pro-S 3-indanyl $\mathrm{CH}), 3.20(\mathrm{~m}, 1 \mathrm{H}, 1$-indanyl $\mathrm{CH}), 7.12-$ $7.17(\mathrm{~m}, 1 \mathrm{H}$, 5-indanyl $\mathrm{CH}), 7.18-7.20(\mathrm{~m}, 1 \mathrm{H}, 6$-indanyl $\mathrm{CH}), 7.20-7.22(\mathrm{~m}, 1 \mathrm{H}, 7-$ indanyl $\mathrm{CH}$ ), 7.22-7.24 (m, 1H, 4-indanyl $\mathrm{CH}) \cdot\left\{{ }^{1} \mathrm{H}\right\}^{13} \mathrm{C}$ NMR $\left(126 \mathrm{MHz}, \mathrm{CDCl}_{3}, 23^{\circ} \mathrm{C}\right): \delta$ $20.06\left(\mathrm{CH}_{3}\right), 31.64$ (3-indanyl $\mathrm{CH}_{2}$ ), 34.95 (2-indanyl $\mathrm{CH}_{2}$ ), 39.60 (1-indanyl $\mathrm{CH}$ ), 123.36 (7-indanyl $\mathrm{CH}$ ), 124.52 (4-indanyl $\mathrm{CH}$ ), 126.27 (5- or 6-indanyl $\mathrm{CH}$ ), 126.29 (5- or 6indanyl CH), 144.09 (4a-indanyl C), 148.94 (7a-indanyl $\mathrm{CH}$ ). See Section VI for determination of diastereotopic aliphatic $\mathrm{CH}$ resonances. ${ }^{1} \mathrm{H}$ and ${ }^{13} \mathrm{C}$ NMR spectra are consistent with previously reported data. ${ }^{49}$ Chiral separation was achieved using chiral GC chromatography according to the following isothermal method: hold at $70 \stackrel{\circ}{ } \mathrm{C}$ for 90 minutes; ramp $20^{\circ} \mathrm{C}$ per minute, hold at $200^{\circ} \mathrm{C}$ for 6 minutes. 


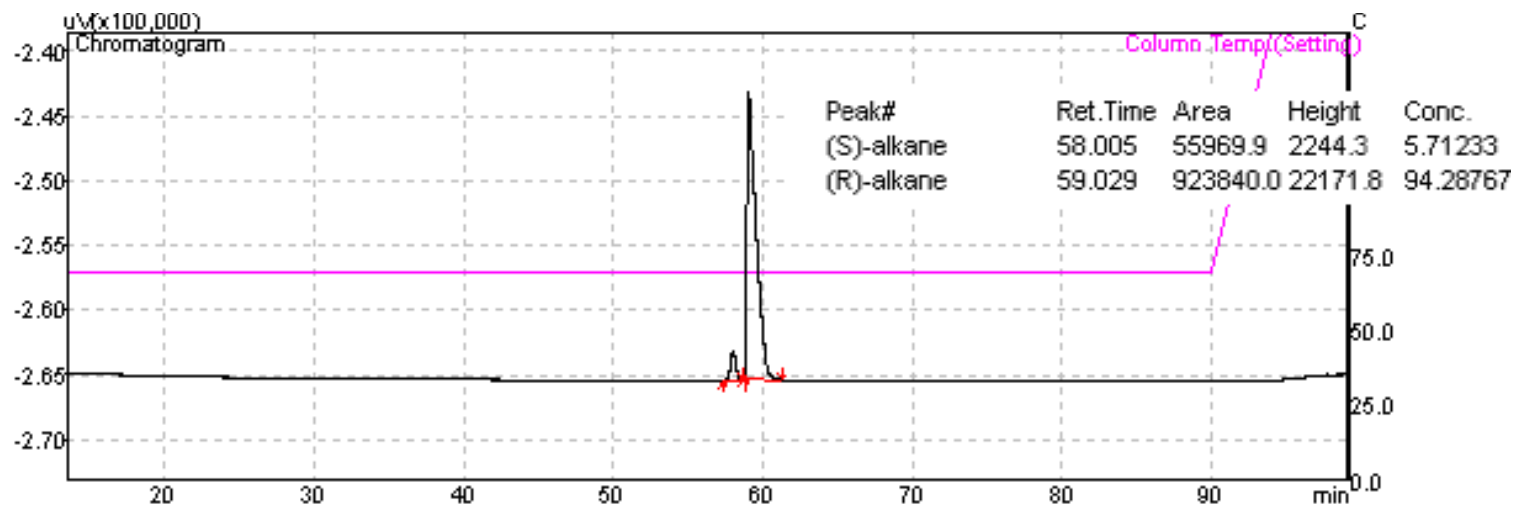

\section{Substrate Optimization Tables}

Entry
Isolated yield, \% ee ${ }^{\mathrm{a}}$

a) Reactions run at $0.25 \mathrm{M}, 4 \mathrm{~mL} \mathrm{PhMe}, 1 \mathrm{mmol}$ alkene substrate, $5 \%(\mathrm{~S})$-CoMe at $25^{\circ} \mathrm{C}$ for $16 \mathrm{~h}$.

b) $\mathrm{Et}_{2} \mathrm{O}$ solvent. ${ }^{\text {c) }} 2 \mathrm{M}$ reaction.

Table S1. Pressure dependence in the asymmetric hydrogenation of some substrates with (S)- $\mathrm{CoCH}_{3}$. 


\begin{tabular}{|c|c|c|c|c|c|}
\hline Entry & Substrate & Product & \multicolumn{3}{|c|}{ Isolated yield, \% ee $e^{a}$} \\
\hline 1 & $17 a$ & & (S)-18 & $\begin{array}{l}0.1 \mathrm{M}: \\
0.25 \mathrm{M}: \\
2 \mathrm{M}:\end{array}$ & $\begin{array}{l}87 \%, 62 \%(S)-(+) \\
87 \%, 53 \%(S)-(+) \\
83 \%, 62 \%(S)-(++\end{array}$ \\
\hline 2 & $19 a$ & & $(R)-20$ & $\begin{array}{l}0.1 \mathrm{M}: \\
0.25 \mathrm{M}: \\
2 \mathrm{M}:\end{array}$ & $\begin{array}{l}80 \%, 63 \%(R)-(+) \\
84 \%, 74 \%(R)-(+) \\
83 \%, 74 \%(R)-(+)\end{array}$ \\
\hline
\end{tabular}

a) Reactions run at $4 \mathrm{~atm} \mathrm{H}_{2}, \mathrm{Et}_{2} \mathrm{O}$ solvent, $1 \mathrm{mmol}$ alkene substrate, $5 \%(S)$-CoMe at $25{ }^{\circ} \mathrm{C}$ for $16 \mathrm{~h}$. All entries were $>95 \%$ convserion to product.

Table S2. Concentration dependence in the asymmetric hydrogenation of representative substrates with (S)-CoCH .

entry Substrate

a) Reactions run at $0.25 \mathrm{M}, 4 \mathrm{~mL} \mathrm{PhMe}, 1 \mathrm{mmol}$ alkene substrate, $5 \%(\mathrm{~S})$-CoMe at $25^{\circ} \mathrm{C}$ for $24 \mathrm{hr}$. b) $2 \mathrm{M}$ reaction, c) $48 \mathrm{hr}$ reaction time.

Table S3. Alkene substrates that were inactive toward asymmetric hydrogenation with (S)- $\mathrm{CoCH}_{3}$. 


\section{Catalytic Hydrogenation of 1a with Precious Metal Catalysts.}

A. Precious metal screen with substrate 1a: (methylallyl) ${ }_{2} R u(C O D)$. To $1 \mathrm{~mL} \times 96$ well plate arrays containing $4.2 \times 10^{-4} \mathrm{mmol}$ each of pre-dispensed phosphine ligands was added $50 \mu \mathrm{L}$ of a $8 \mathrm{mM}$ 1,2-dichloroethane solution of (methylallyl) $)_{2} R u(C O D)$ to each reaction well, followed by 20 minutes of mixing. To the well plates were added 50 $\mu \mathrm{L}$ of $16 \mathrm{mM}$ 1,2-dichloroethane solution of $\mathrm{HBF}_{4}$ followed by mixing for 20 minutes. Next, the volatile components were removed in vacuo using a vacuum centrifuge. To each reaction well was added $100 \mu \mathrm{L}$ of a $16 \mathrm{mM}$ methanol solution of 3-phenylindene (1a). The 96 well plate was then sealed in a high-pressure block and vented with nitrogen gas and was then connected to a $1 \mathrm{~L}$ gas buret, followed by venting with hydrogen gas. The block and buret were both pressurized to $500 \mathrm{psi} \mathrm{H}_{2}$. The apparatus was agitated via mechanical shaking at $40{ }^{\circ} \mathrm{C}$ for 20 hours, at which point the block was vented with nitrogen gas and the 96 well plate was removed. The samples were then prepared by methanol dilution to approximately $1 \mathrm{mg} / \mathrm{ml}$ concentration for chiral HPLC analysis with the following parameters: $150 \times 4.5 \mathrm{~mm} 5 \mu \mathrm{m}$ OJ-RH, $1 \mathrm{~mL} / \mathrm{min}, 80 \% \mathrm{MeCN}$ / $20 \% 0.1 \% \mathrm{H}_{3} \mathrm{PO}_{4}, 10 \mathrm{~min}, 25 \stackrel{\circ}{\circ}, 210 \mathrm{~nm}$. Product enantiomer 1: $4.56 \mathrm{~min}$; alkene: $4.95 \mathrm{~min}$; product enantiomer 2: $5.46 \mathrm{~min}$.

\section{B. Precious metal screen with substrate $1 \mathrm{a}:\left[(\mathrm{NBD})_{2} \mathrm{Rh}\left[\mathrm{BF} \mathrm{F}_{4}\right]\right.$ and $\left[(\mathrm{COD})_{2} \mathrm{Ir}\right]\left[\mathrm{BAr}{ }_{4}\right]$}

To $1 \mathrm{~mL} \times 96$ well plate arrays containing $4.2 \times 10^{-4} \mathrm{mmol}$ each of pre-dispensed phosphine ligands was added $100 \mu \mathrm{L}$ of a $4 \mathrm{mM}$ solution of $\left[(\mathrm{NBD})_{2} \mathrm{Rh}\right]\left[\mathrm{BF}_{4}\right](\mathrm{NBD}=$ norbornadiene) in 1,2-dichloroethane or [(COD) $\left.{ }_{2} \mid r\right]\left[B A r_{4}{ }_{4}\right]$ in 1,2-dichloroethane to each reaction well, followed by 20 minutes of mixing. Next, the volatile components were removed in vacuo using a vacuum centrifuge. To each reaction well was added $100 \mu \mathrm{L}$ of a $16 \mathrm{mM}$ methanol or dichloromethane solution of 3-phenylindene (1a). The 96 well plate was then sealed in a high-pressure block and vented with nitrogen gas and was 
then connected to a $1 \mathrm{~L}$ gas buret, followed by venting with hydrogen gas. The block and buret were both pressurized to 500 psi $\mathrm{H}_{2}$. The apparatus was agitated via mechanical shaking at $40 \stackrel{\circ}{ } \mathrm{C}$ for 20 hours, at which point the block was vented with nitrogen gas and the 96 well plate was removed. The samples were then prepared for chiral HPLC analysis by methanol dilution to approximately $1 \mathrm{mg} / \mathrm{ml}$ concentration.

\begin{tabular}{|c|c|c|c|}
\hline metal precursor / solvent ${ }^{2}$ & ligand & $\begin{array}{c}\% \text { conversion } \\
\text { to alkane }\end{array}$ & $\begin{array}{c}\text { relative } \\
\% \text { ee }\end{array}$ \\
\hline \multirow{9}{*}{$\operatorname{Ir}(\mathrm{COD})_{2} \mathrm{BAr}_{4} / \mathrm{DCM}$} & SL-N007-2 & $>99 \%$ & $+98 \%$ \\
\hline & SL-N003-2 & $>99 \%$ & $+96 \%$ \\
\hline & SL-N013-1 & $>99 \%$ & $-88 \%$ \\
\hline & SL-N004-2 & $>99 \%$ & $+82 \%$ \\
\hline & SL-J504-2 & $>99 \%$ & $+80 \%$ \\
\hline & (S)-NeoPHOX & $99 \%$ & $+78 \%$ \\
\hline & SL-N008-2 & $>99 \%$ & $+72 \%$ \\
\hline & (R)-Ph-PHOX & $>99 \%$ & $-70 \%$ \\
\hline & (S)-tBu,o-Tol-PHOX & $>99 \%$ & $+63 \%$ \\
\hline \multirow[t]{6}{*}{$\operatorname{Ir}(\mathrm{COD})_{2} \mathrm{BAr}_{4} / \mathrm{MeOH}$} & SL-A-121-1 & $97 \%$ & $+90 \%$ \\
\hline & (+)-catASium I & $97 \%$ & $-89 \%$ \\
\hline & $(S, S, S, S)$-Me-KetalPhos & $48 \%$ & $-87 \%$ \\
\hline & (S)-DTBM-Garphos & $95 \%$ & $-79 \%$ \\
\hline & SL-A109-2 & $97 \%$ & $-78 \%$ \\
\hline & (R)-DTBM-Segphos & $96 \%$ & $+69 \%$ \\
\hline
\end{tabular}

a. Reactions run at $0.016 \mathrm{M}, 0.1 \mathrm{~mL}$ solvent, $25 \%$ metal precursor and ligand, 500 psi $\mathrm{H}_{2}, 40^{\circ} \mathrm{C}$ for $20 \mathrm{hr}$.

Table S4. Percent conversion and percent enantiomeric excess $(\%$ ee) for all precious metal / ligand combinations that gave $>50 \%$ ee. 


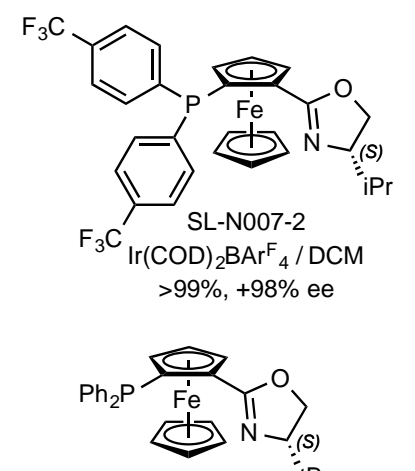

SL-N004-2

$\operatorname{Ir}(\mathrm{COD}){ }_{2} \mathrm{BAr}_{4} / \mathrm{DCM}$ $>99 \%,+82 \%$ ee

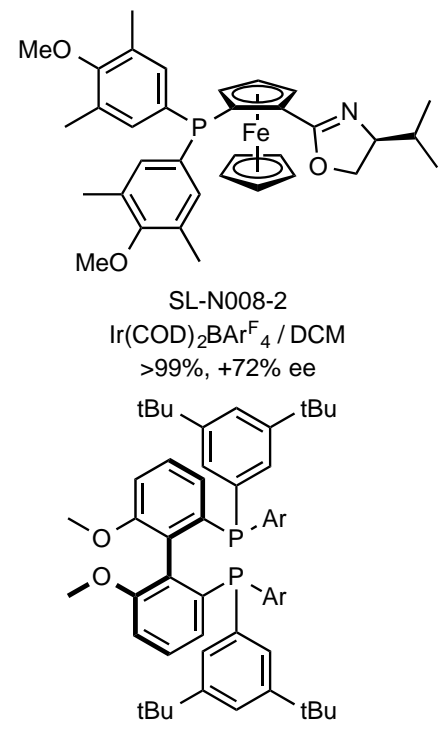

SL-A121-1 $\operatorname{Ir}(\mathrm{COD})_{2} \mathrm{BArF}_{4} / \mathrm{MeOH}$

$97 \%,+90 \%$ ee

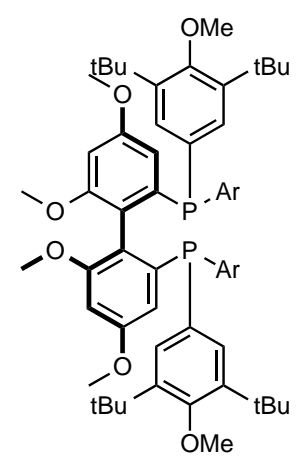

(R)-DTBM-Garphos $\operatorname{Ir}(\mathrm{COD})_{2} \mathrm{BAr}_{4} / \mathrm{MeOH}$

$96 \%,+69 \%$ ee<smiles></smiles>

SL-N003-2 $\operatorname{lr}(\mathrm{COD}){ }_{2} \mathrm{BAr}_{4} / \mathrm{DCM}$ $>99 \%,+96 \%$ ee<smiles>Cc1ccccc1P(c1ccccc1C)C(C)C(O)C1CCCC1</smiles>

SL-J504-2 $\operatorname{Ir}(\mathrm{COD})_{2} \mathrm{BArF}_{4} / \mathrm{DCM}$ $>99 \%,+80 \%$ ee

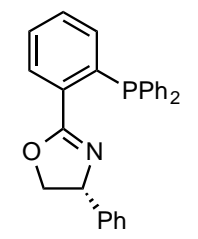

(R)-Ph-PHOX $\operatorname{Ir}(\mathrm{COD})_{2} \mathrm{BArF}_{4} / \mathrm{DCM}$ $>99 \%,-70 \%$ ee

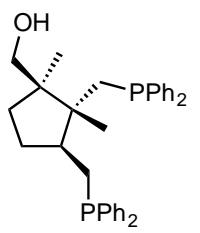

(+)-catASium I $\operatorname{lr}(\mathrm{COD})_{2} \mathrm{BArF}_{4} / \mathrm{MeOH}$ $97 \%,-89 \%$ ee<smiles>COc1cccc(P([Al])c2cc(CC(C)C)c(OC)c(CC(C)C)c2)c1-c1c(OC)cccc1[PH]([Al])([Al])c1cc(CC(C)C)c(OC)c(CC(C)C)c1</smiles>

SL-A109-2 $\operatorname{Ir}(\mathrm{COD})_{2} \mathrm{BArF}_{4} / \mathrm{MeOH}$

$97 \%,-78 \%$ ee<smiles>Cc1ccccc1P(c1ccccc1C)c1ccccc1C1=N[C@@H](C(C)C)CO1</smiles>

SL-N013-1

$\operatorname{lr}(\mathrm{COD})_{2} \mathrm{BAr}_{4} / \mathrm{DCM}$

$>99 \%,-88 \%$ ee<smiles>CC(C)[C@H]1COC(C(C)(C)Cc2ccccc2)=N1</smiles>

(S)-NeoPHOX $\operatorname{lr}(\mathrm{COD}){ }_{2} \mathrm{BArF}_{4} / \mathrm{DCM}$ $99 \%,+78 \%$ ee

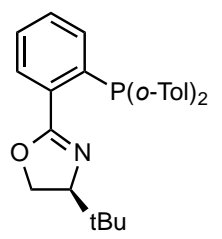

(S)-tBu,o-Tol-PHOX $\operatorname{lr}(\mathrm{COD}){ }_{2} \mathrm{BArF}_{4} / \mathrm{DCM}$ $>99 \%,+63 \%$ ee<smiles>CC1C2OC(C)(C)O[C@H]2C(C)P1c1ccccc1P1C(C)[C@H]2OC(C)(C)O[C@H]2C1C</smiles>

(S, S, S, S)-Me-KetalPhos $\operatorname{Ir}(\mathrm{COD})_{2} \mathrm{BArF}_{4} / \mathrm{MeOH}$ $48 \%,-87 \%$ ee<smiles>COc1c(CC(C)C)cc(P([Te])c2ccc3c(c2-c2c([PH]([Te])([Te])c4cc(CC(C)C)c(OC)c(CC(C)C)c4)ccc4c2OCO4)OCO3)cc1CC(C)C</smiles>

SL-A109-2 $\operatorname{lr}(\mathrm{COD}){ }_{2} \mathrm{BAr}_{4} / \mathrm{MeOH}$ $97 \%,-78 \%$ ee

Figure S3. Ligands that, in combination with the listed precious metal precursor and solvent gave $>50 \%$ ee for the hydrogenation of 1 a. 


\section{Deuterium Labeling Studies.}

A. Procedure for Catalytic Deuteration with (S)- $\mathrm{CoCH}_{3}$. In a nitrogen-filled glovebox, a flame-dried, sealable thick-walled glass vessel was charged with $0.025 \mathrm{~g}(0.05 \mathrm{mmol})$ (S)- $C_{1}$ PDICoMe, $2 \mathrm{ml}$ of $\mathrm{C}_{6} \mathrm{H}_{6}$ and a magnetic stirbar. The glass vessel was sealed and attached to a high-vacuum line and the contents frozen in liquid nitrogen. Following evacuation of the nitrogen atmosphere, the vessel was pressurized with 1 atm deuterium gas at $77 \mathrm{~K}$ and re-sealed. Upon warming to room temperature, the contents were stirred for 5 minutes (the pressure at room temperature was $\sim 4$ atm). The vessel was reattached to the high-vacuum line and frozen in liquid nitrogen. Following evacuation of the headspace, the vessel was pressurized with 1 atm of deuterium gas at $77 \mathrm{~K}$ and resealed, warmed to room temperature and stirred for 5 minutes. This procedure was repeated once more. After 5 minutes stirring at room temperature, the vessel was reassembled on the high-vacuum line and degassed. The vessel was brought into the glovebox and the purple benzene solution was frozen in the cold well. The vessel was then charged with $0.192 \mathrm{~g}(1.0 \mathrm{mmol})$ of 3-phenylindene and $2 \mathrm{ml}$ of $\mathrm{C}_{6} \mathrm{H}_{6}$. Upon freezing of the reaction contents in the cold well, the vessel was sealed and attached to the highvacuum line and was then frozen in liquid nitrogen. Following evacuation of the headspace, the vessel was pressurized with 1 atm of deuterium gas at $77 \mathrm{~K}$ and resealed. Upon warming to room temperature, the purple solution was stirred for 18 hours at $25^{\circ} \mathrm{C}$. The vessel was then vented and diluted with $\sim 15 \mathrm{ml}$ hexane. The reaction mixture was passed through a plug of silica, eluting with hexane. Following solvent evaporation, $0.181 \mathrm{~g}(0.93 \mathrm{mmol}, 92 \%$ yield $)$ of the alkane product $2 \mathrm{a}$ was isolated as a clear oil. Chiral GC analysis established full conversion to product at $94 \%$ ee of the (S)(-) enantiomer. This procedure was repeated using $0.144 \mathrm{~g}(1.0 \mathrm{mmol})$ 1-methyl-3,4dihydronaphthalene to obtain $0.120 \mathrm{~g}(0.82 \mathrm{mmol}, 82 \%$ yield $)$ of alkane product. Chiral GC analysis established full conversion to product at $98 \%$ ee of the $(S)-(-)$ enantiomer. 
B. Establishment of syn-anti disposition of aliphatic protons in 1-phenylindane.

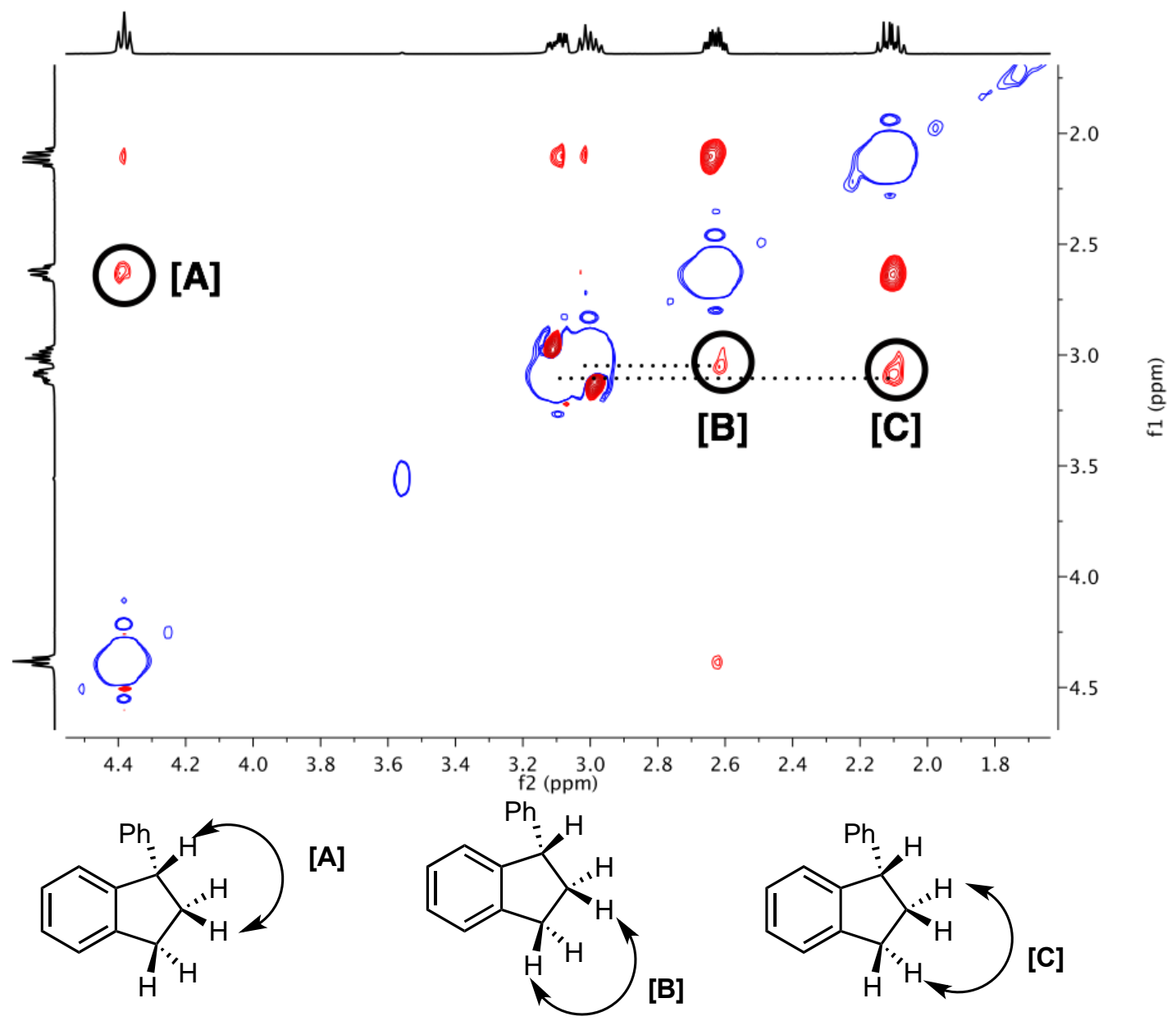

Figure S4. NOESY ${ }^{1} \mathrm{H}$ NMR spectrum of 1-phenylindane (top) and the corresponding through-space interactions of the aliphatic protons (bottom). 


\section{NMR spectra of 1-phenylindane- $d_{3}$.}

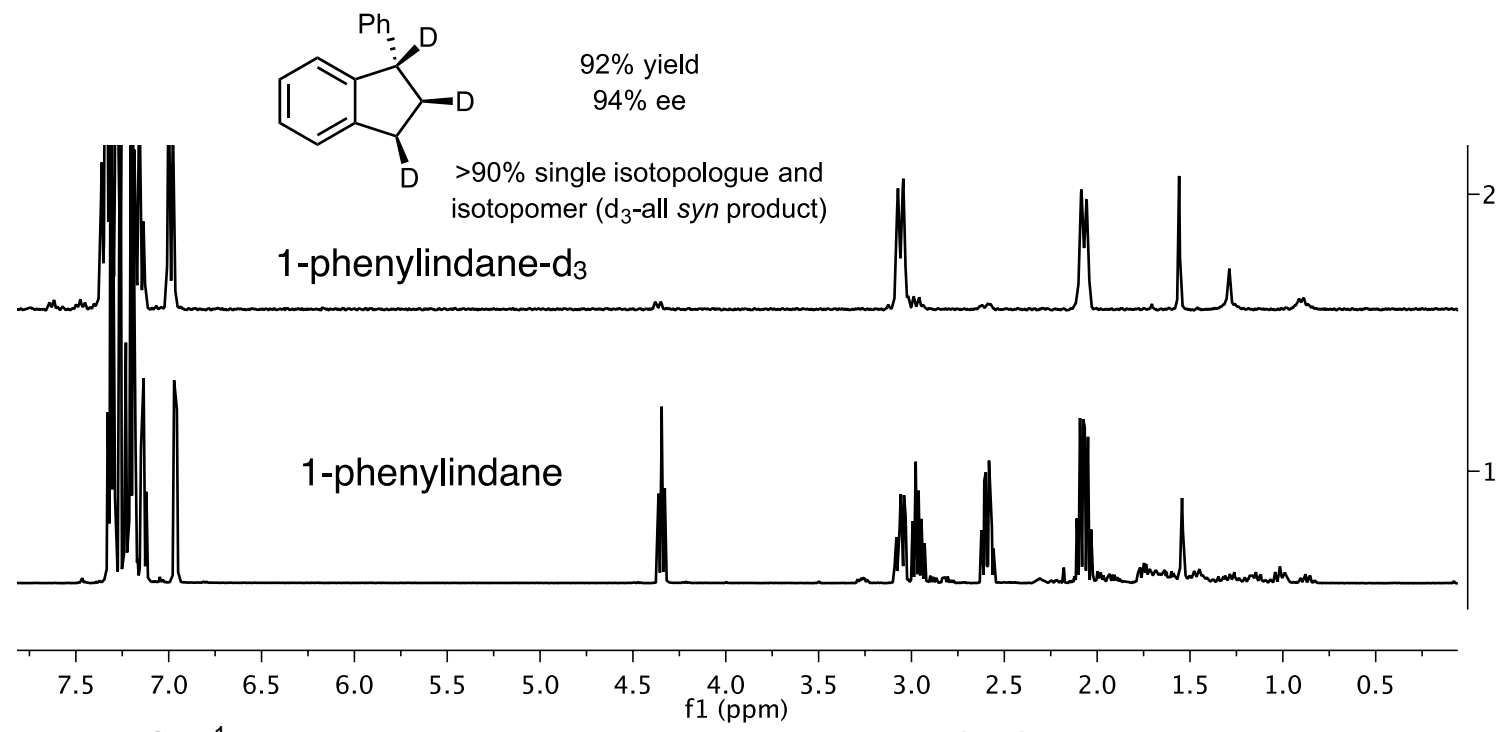

Figure S5. ${ }^{1} \mathrm{H}$ NMR spectrum of alkane products $1 \mathrm{a}-d_{3}$ (top) and $1 \mathrm{a}$.

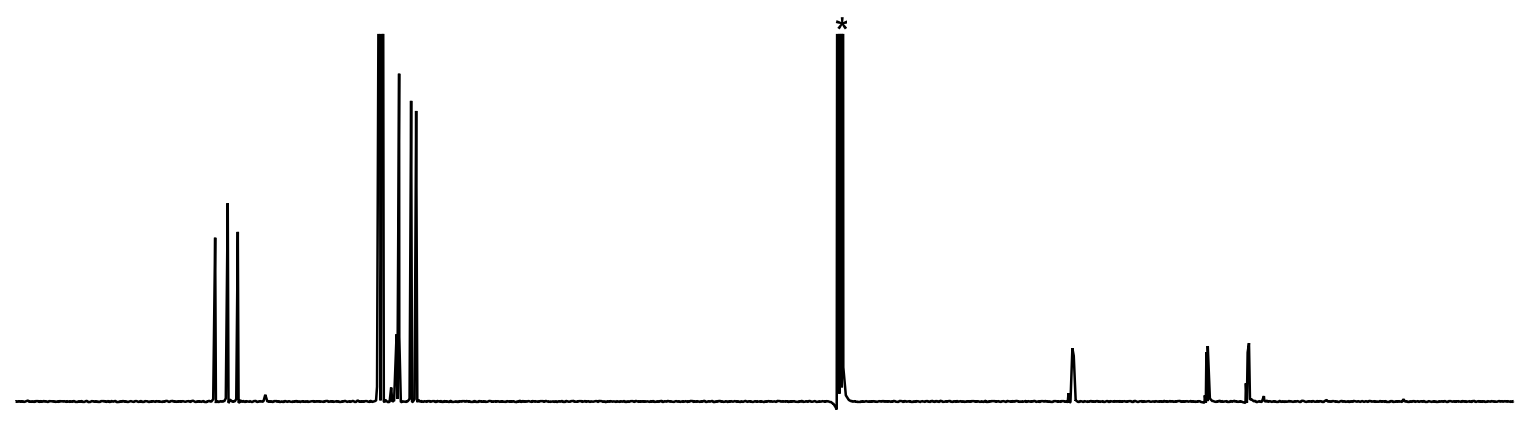

\begin{tabular}{|c|c|c|c|c|c|c|c|c|c|c|c|c|c|c|}
\hline 1 & 1 & $T$ & 1 & 1 & 1 & 1 & 1 & 1 & $T$ & $T$ & $T$ & $T$ & 1 & 1 \\
\hline 160 & 150 & 140 & 130 & 120 & 110 & 100 & $\begin{array}{l}90 \quad 80 \\
\text { f1 (ppm) }\end{array}$ & 70 & 60 & 50 & 40 & 30 & 20 & 10 \\
\hline
\end{tabular}

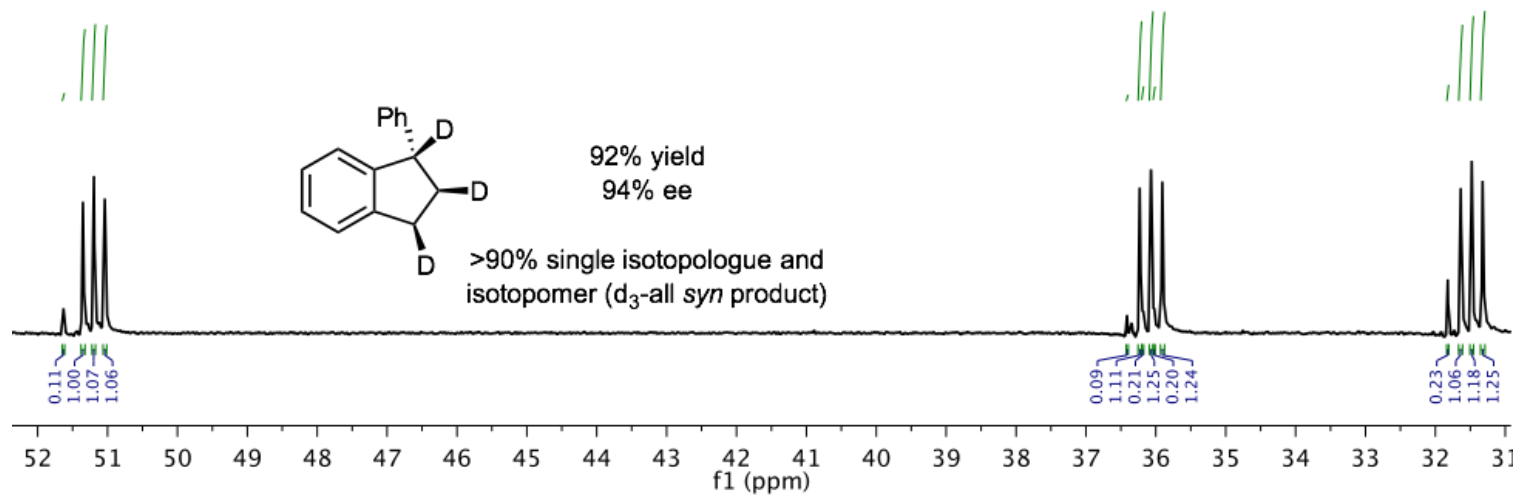

Figure S6. Full quantitative ${ }^{13} \mathrm{C}$ NMR spectrum of $1 \mathrm{a}-\mathrm{d}_{3}$ (top), and aliphatic region showing the three $\mathrm{sp}^{3}$ carbons (bottom). 
D. NMR spectra of the deuteration of 1-phenyl-1H-indene (1g).

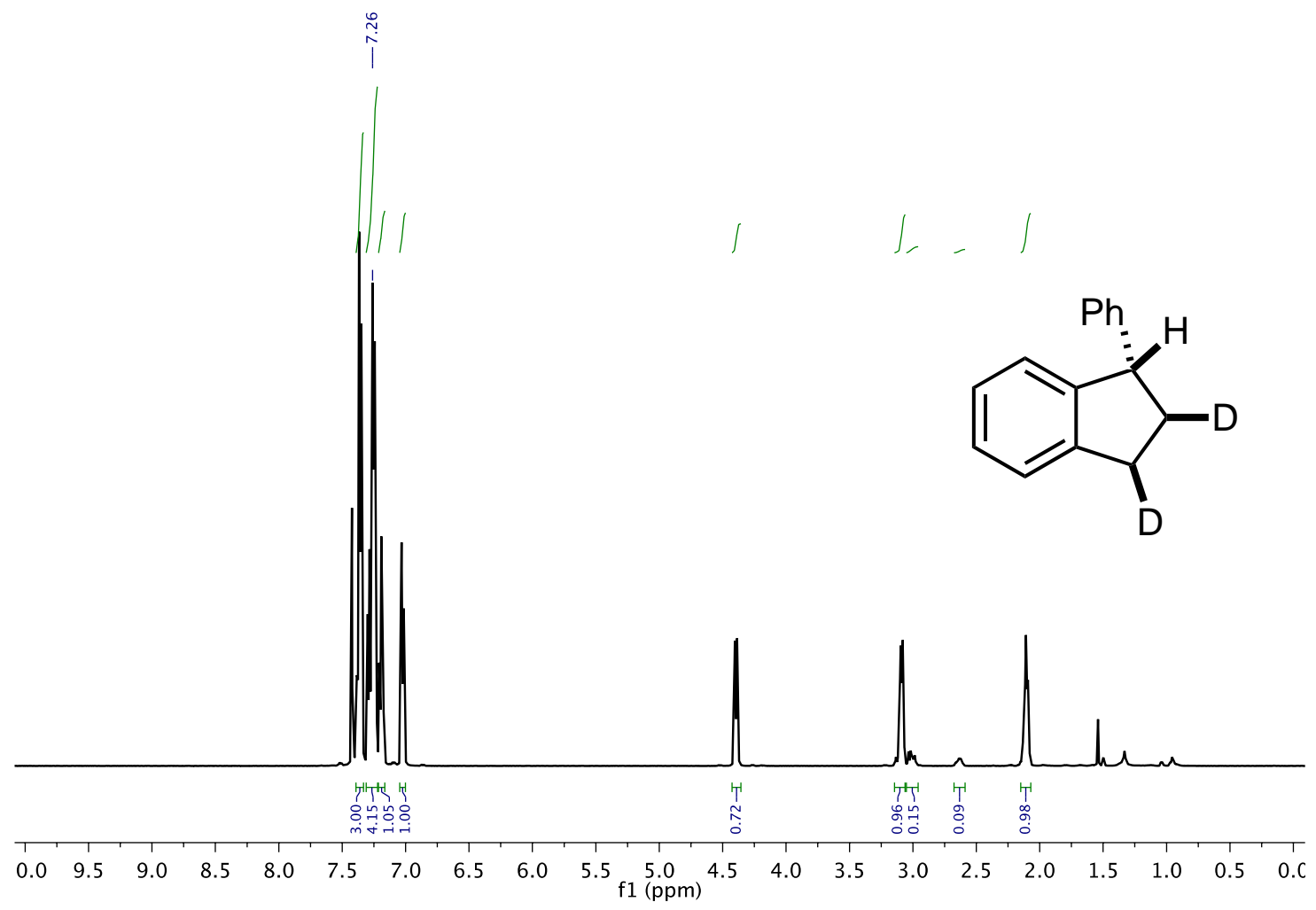

Figure S7. ${ }^{1} \mathrm{H}$ NMR spectrum of alkane product 1-phenylindane- $d_{2}$.

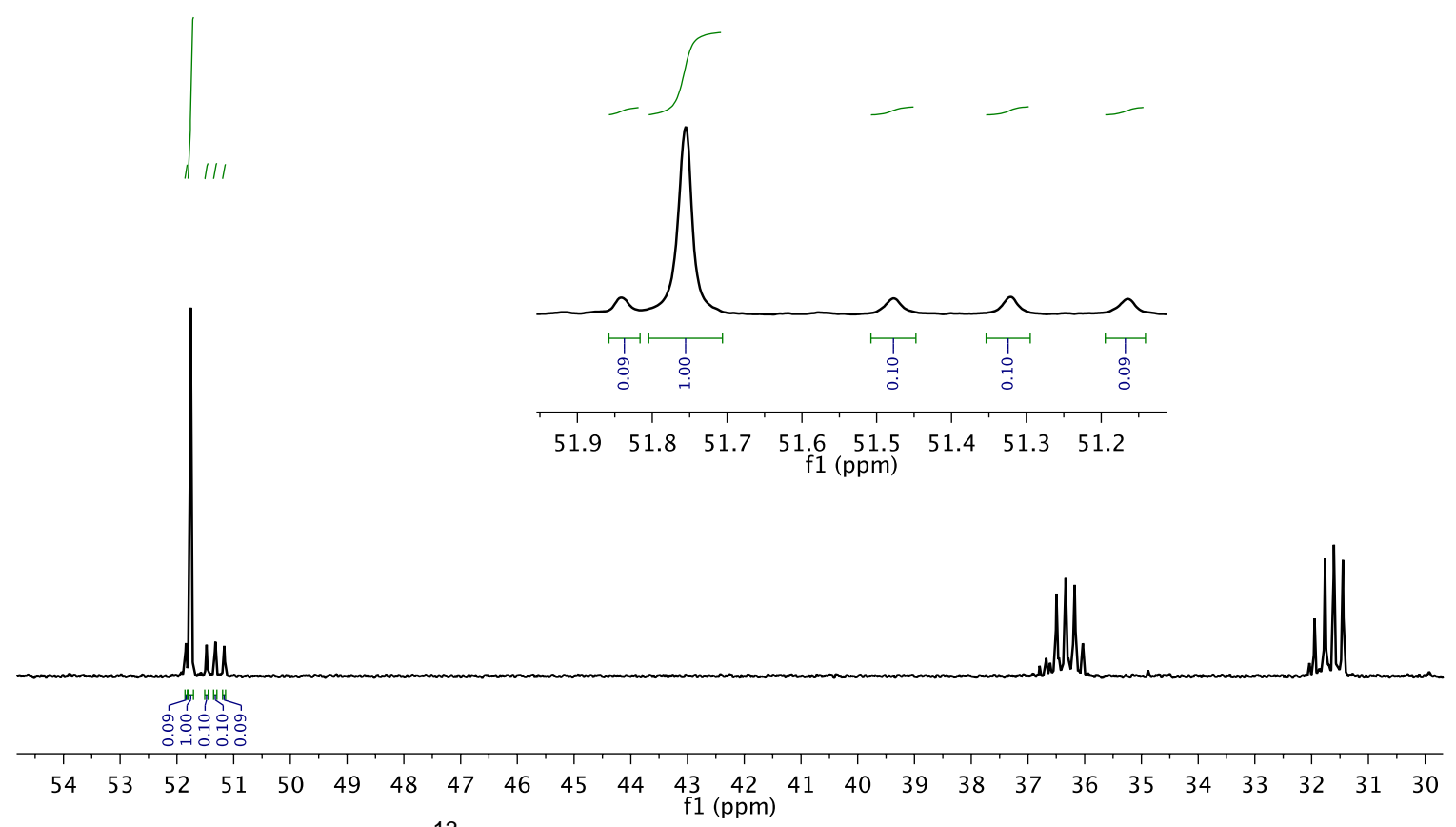

Figure S8. Quantitative ${ }^{13} \mathrm{C}-\mathrm{NMR}$ spectrum (aliphatic region) 1-phenyllindane- $\mathrm{d}_{2}$ with some integrations. 
E. NMR spectra of the deuteration of 1-exo-methylene-benzosuberane.

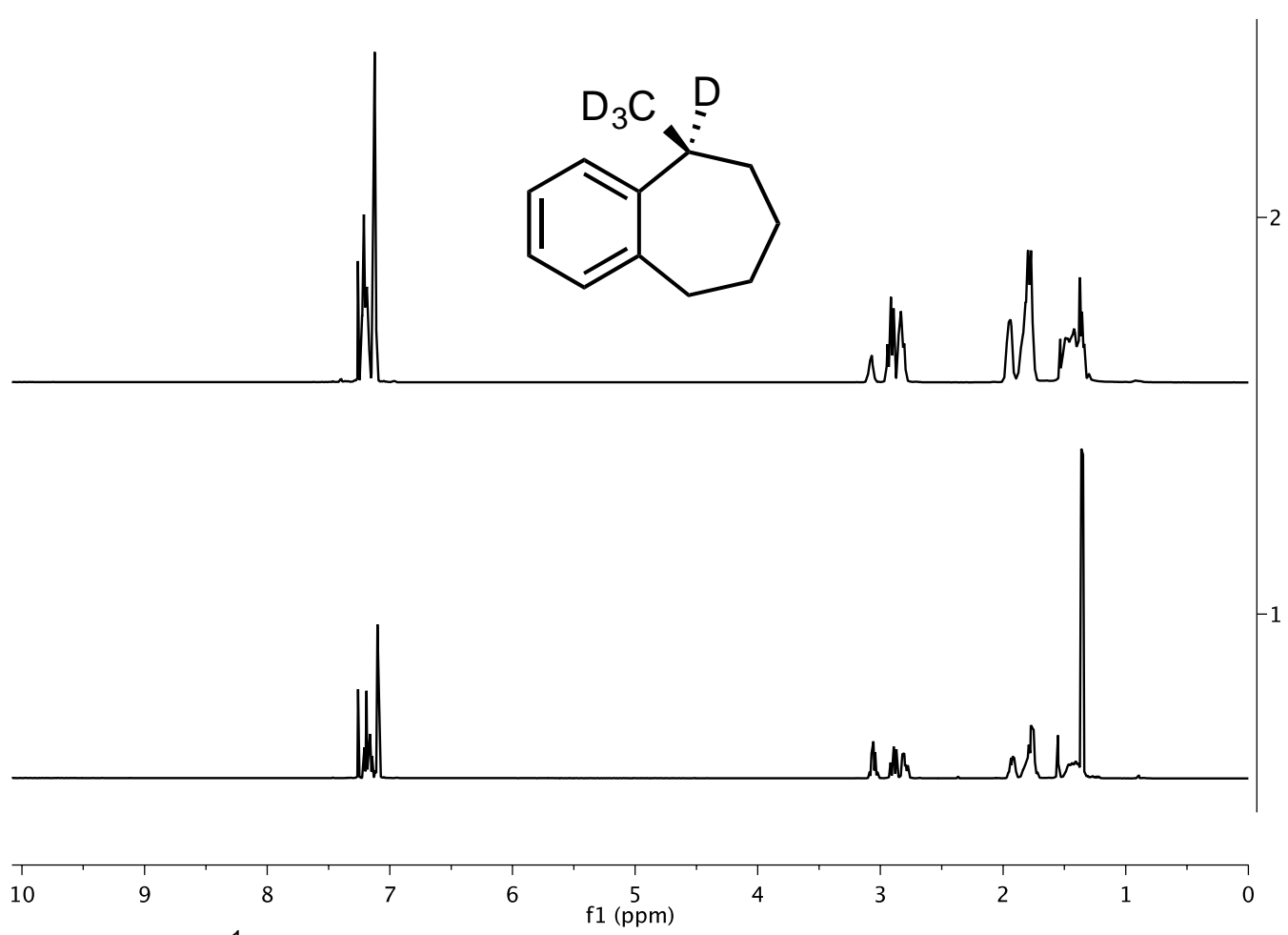

Figure S9. ${ }^{1} \mathrm{H}$ - NMR spectra of 1-methylbenzosuberan- $\mathrm{d}_{4}$ (top) and all-protio 1methylbenzosuberan.

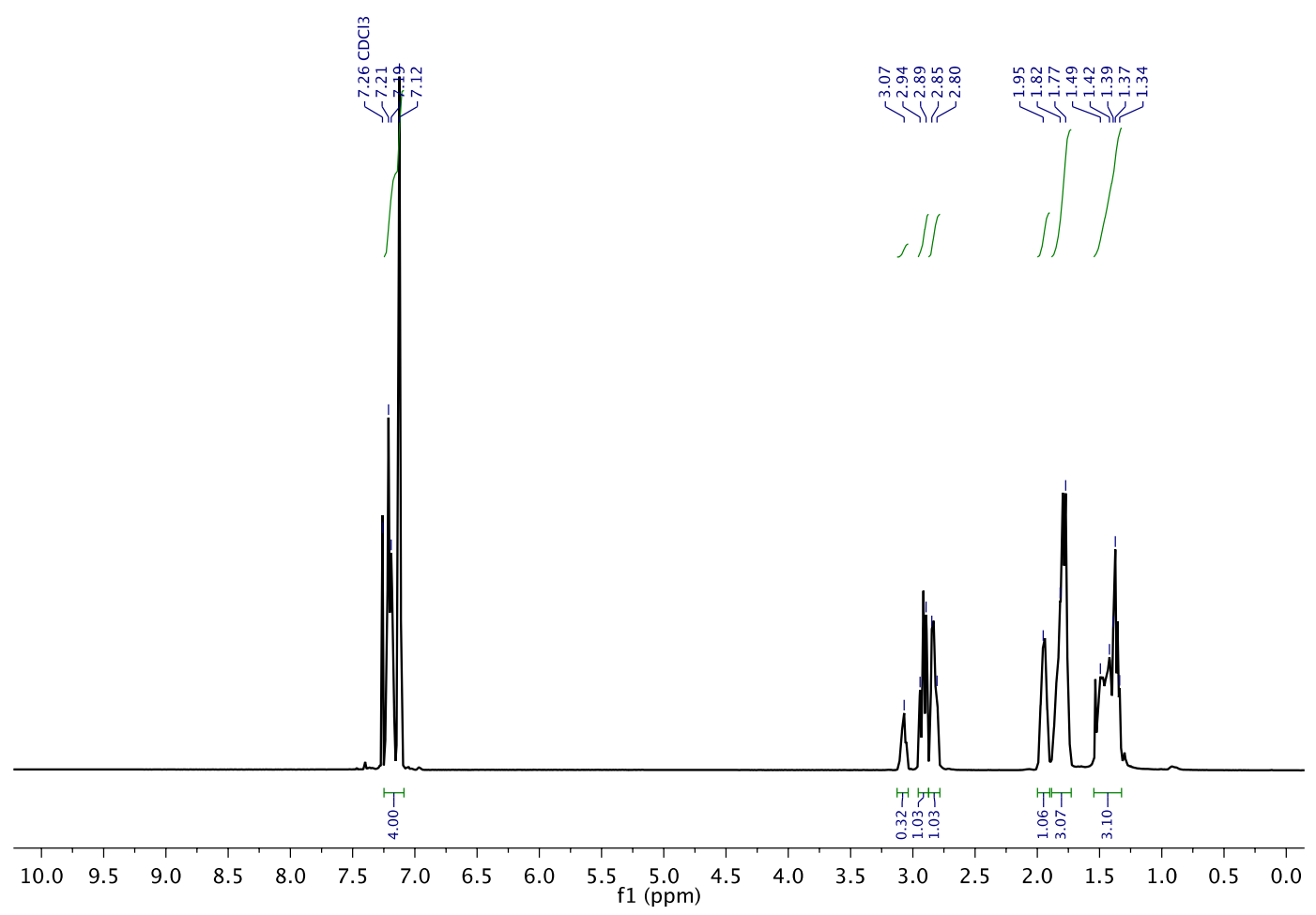

Figure S10. ${ }^{1} \mathrm{H}-\mathrm{NMR}$ spectrum of 1 -methylbenzosuberan- $\mathrm{d}_{4}$ with integrations. 


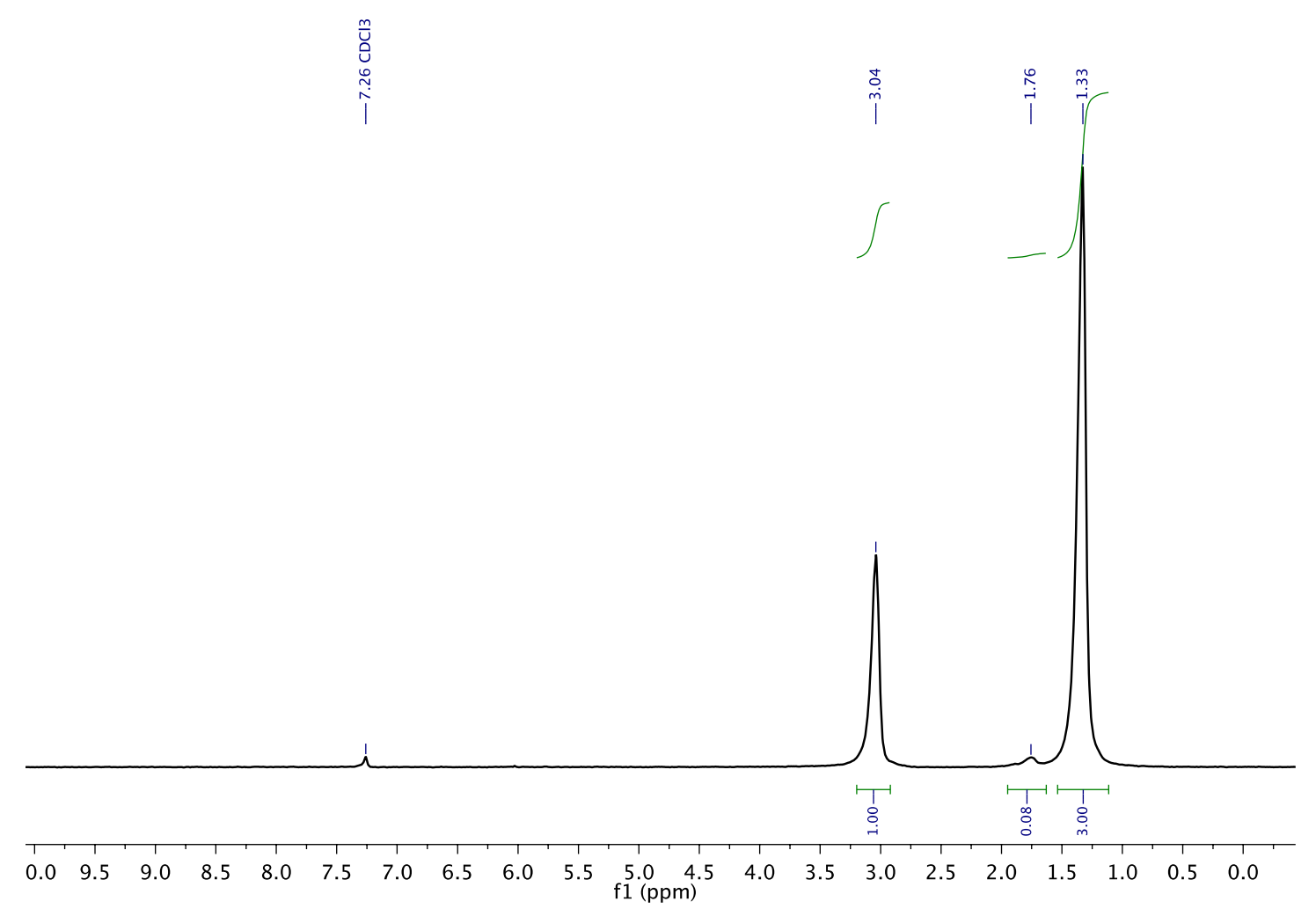

Figure S11. ${ }^{2} \mathrm{H}-\mathrm{NMR}$ spectrum of 1 -methylbenzosuberan- $\mathrm{d}_{4}$ with integrations establishing the 3:1 deuterium incorporation into the methyl and 1-position of the ring, respectively.

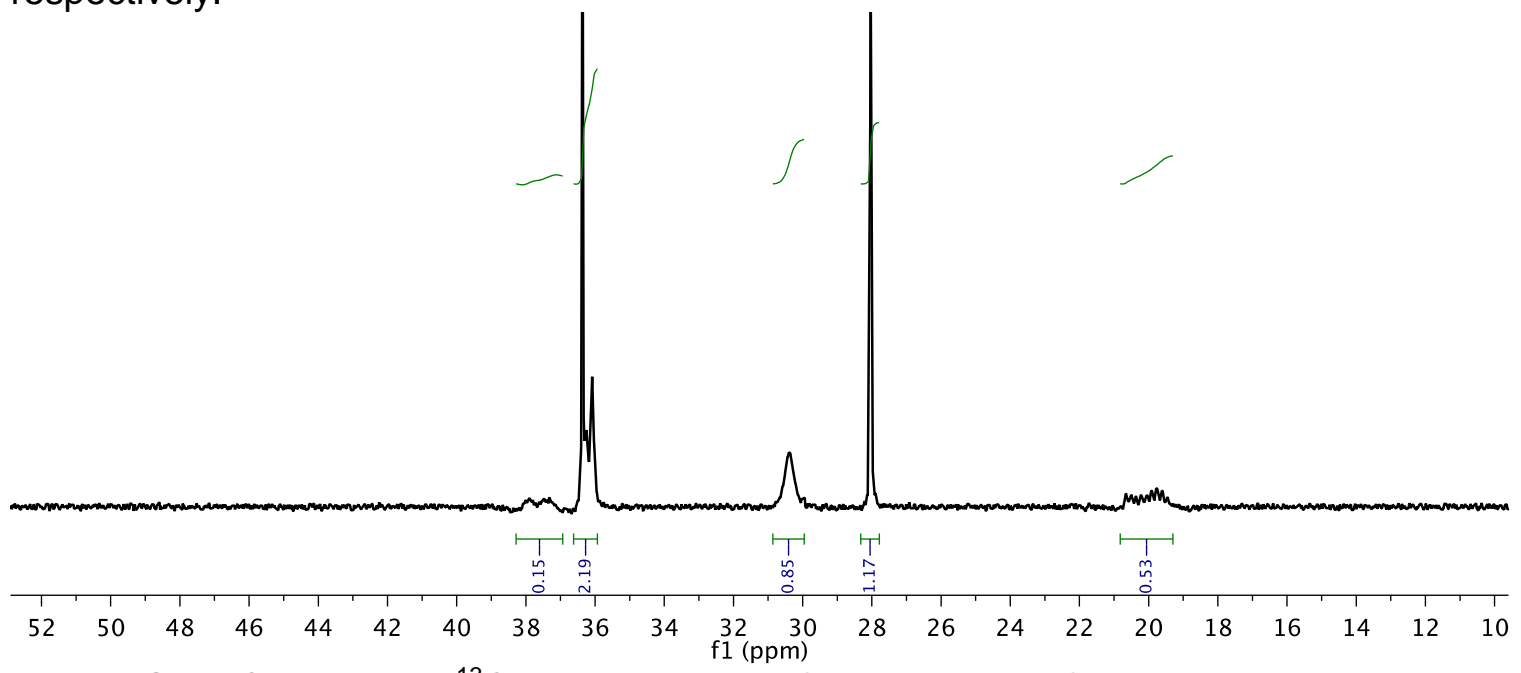

Figure S12. Quantitative ${ }^{13} \mathrm{C}-N M R$ spectrum (aliphatic region) collected at $293 \mathrm{~K}$ of 1 methylbenzosuberan- $d_{4}$ with integrations. The unexpected number of peaks and integration values are likely due to fluxional processes in the ring. 


\section{F. NMR spectra of the deuteration of 1-methyl-benzosuberene (3b).}

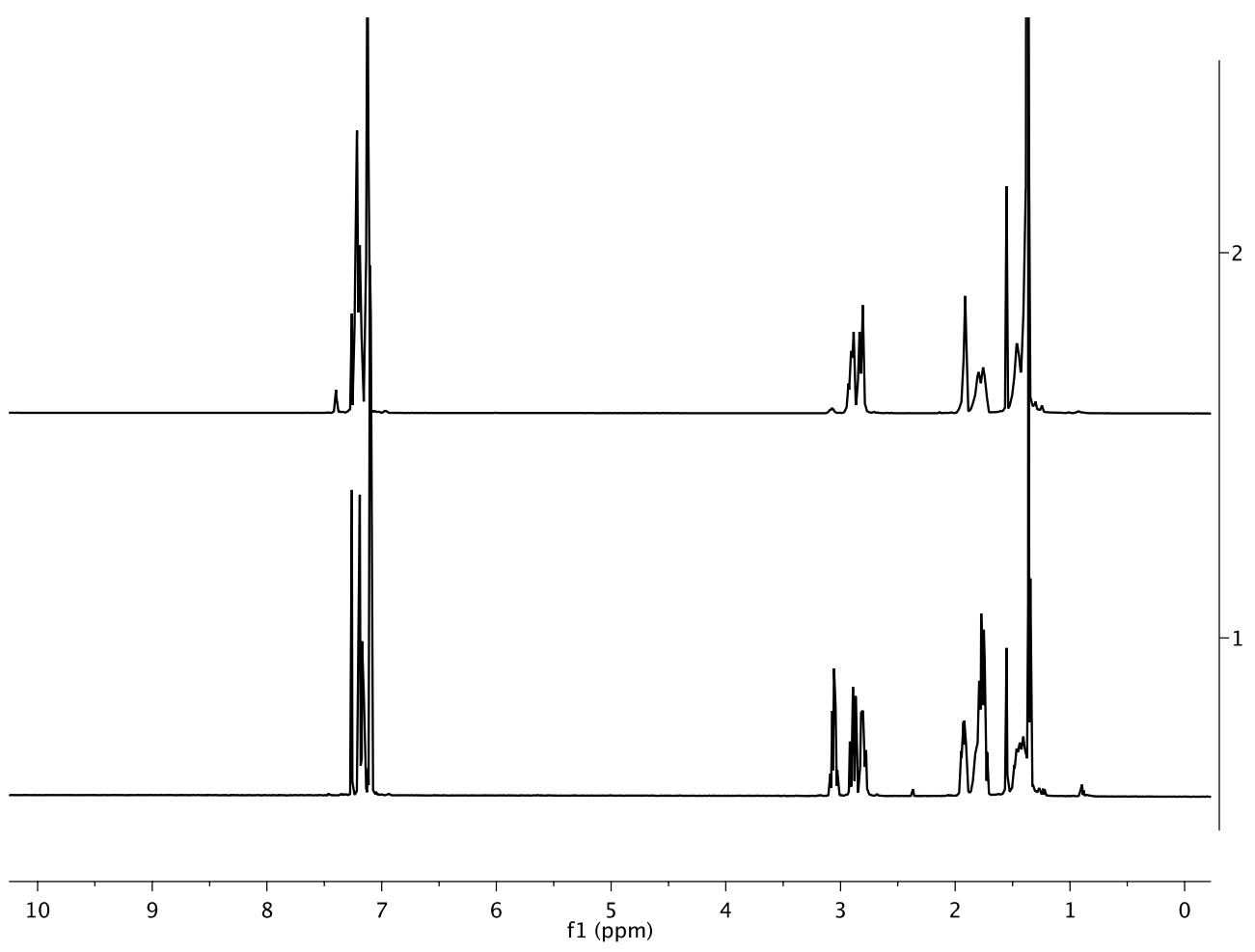

Figure S13. ${ }^{1} \mathrm{H}-\mathrm{NMR}$ spectra of 1-methylbenzosuberan- $\mathrm{d}_{\mathrm{n}}$ (top) and all-protio 1methylbenzosuberan.

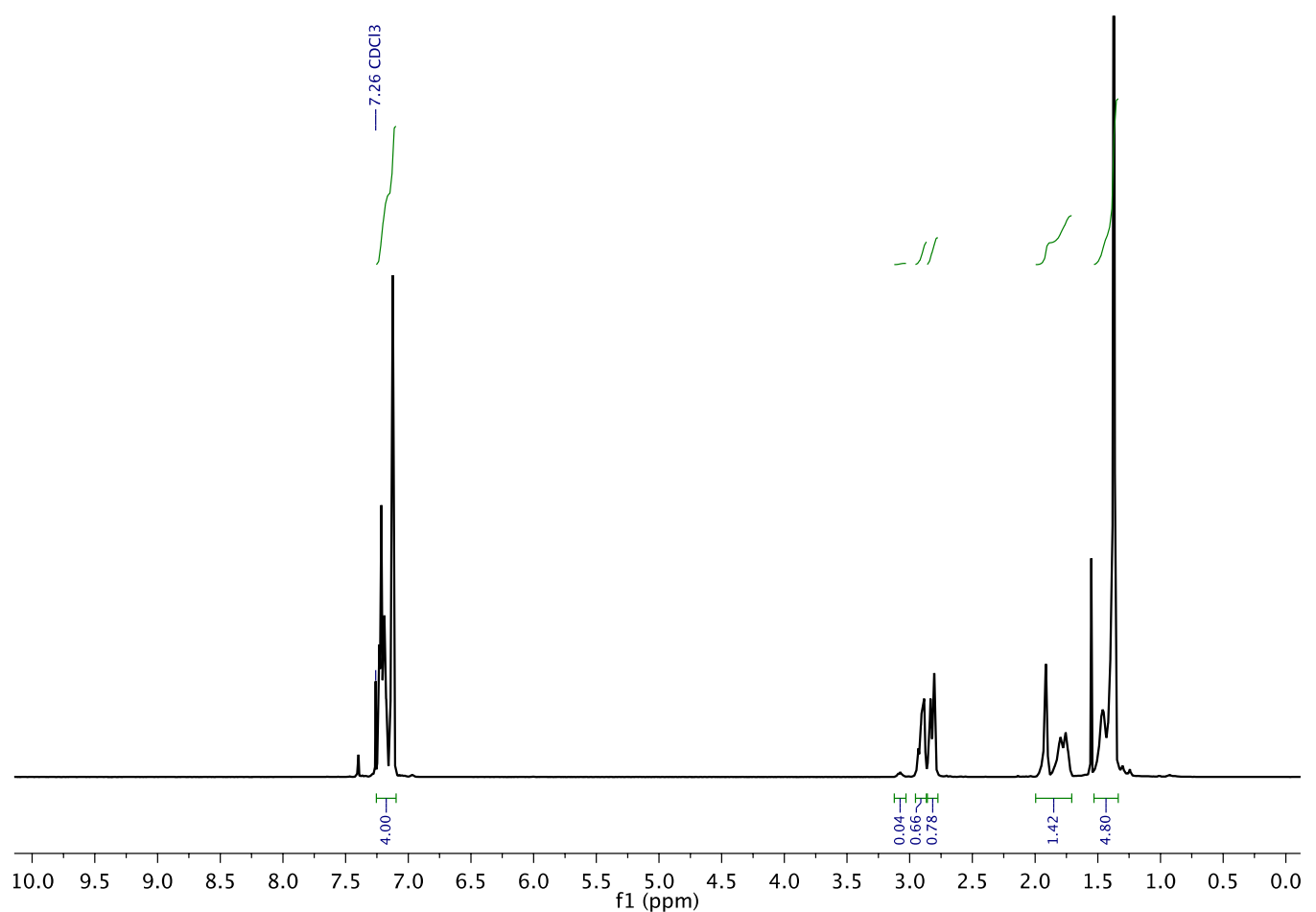

Figure S14. ${ }^{1} \mathrm{H}-\mathrm{NMR}$ spectrum of 1 -methylbenzosuberan- $\mathrm{d}_{4}$ with integrations showing variable deuterium incorporation into methylene positions in the ring. 


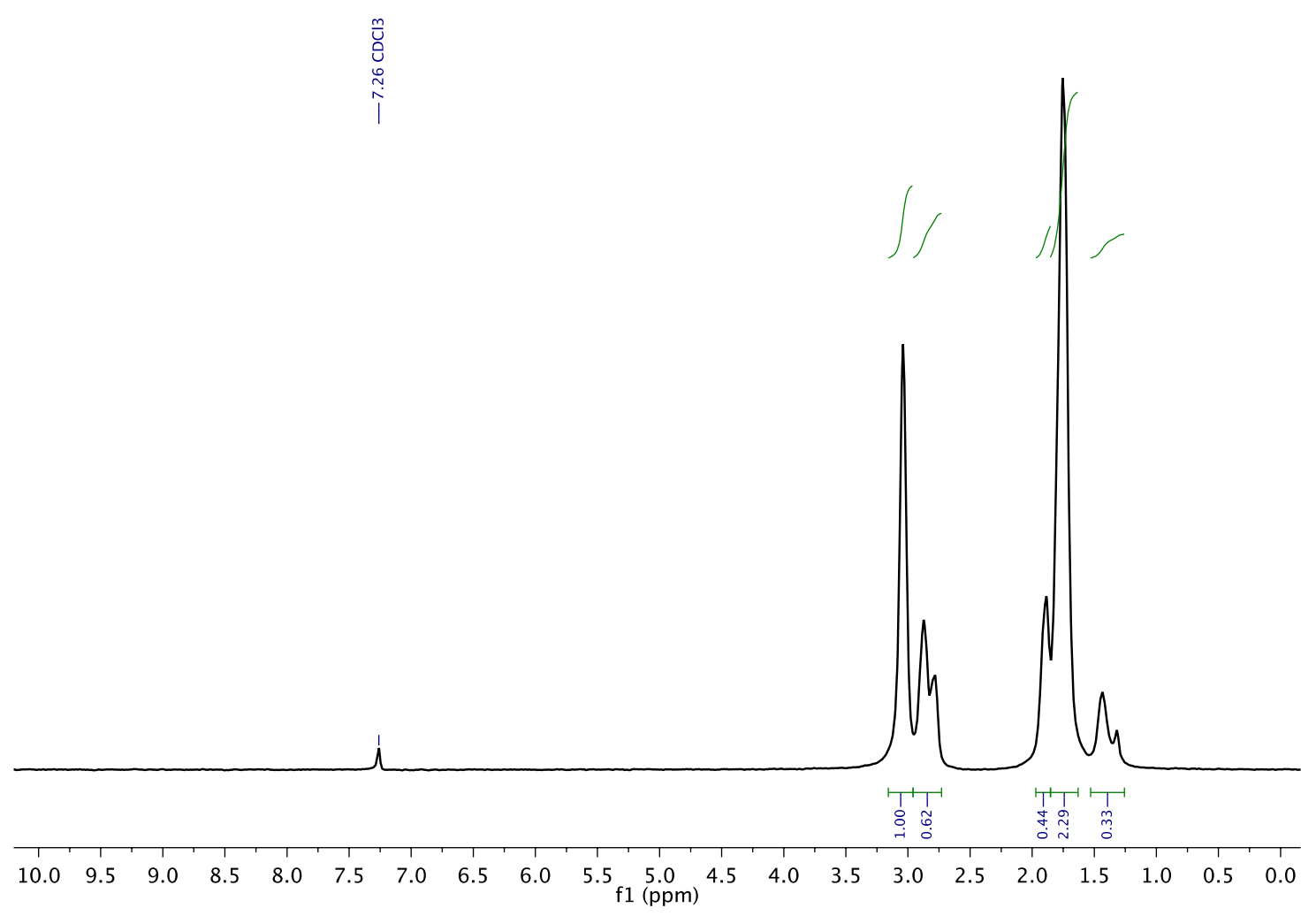

Figure S15. ${ }^{2} \mathrm{H}-\mathrm{NMR}$ spectrum of 1 -methylbenzosuberan- $\mathrm{d}_{\mathrm{n}}$ with integrations establishing the variable deuterium incorporation into the ring methylene positions, while also establishing little deuterium incorporation into the methyl position.
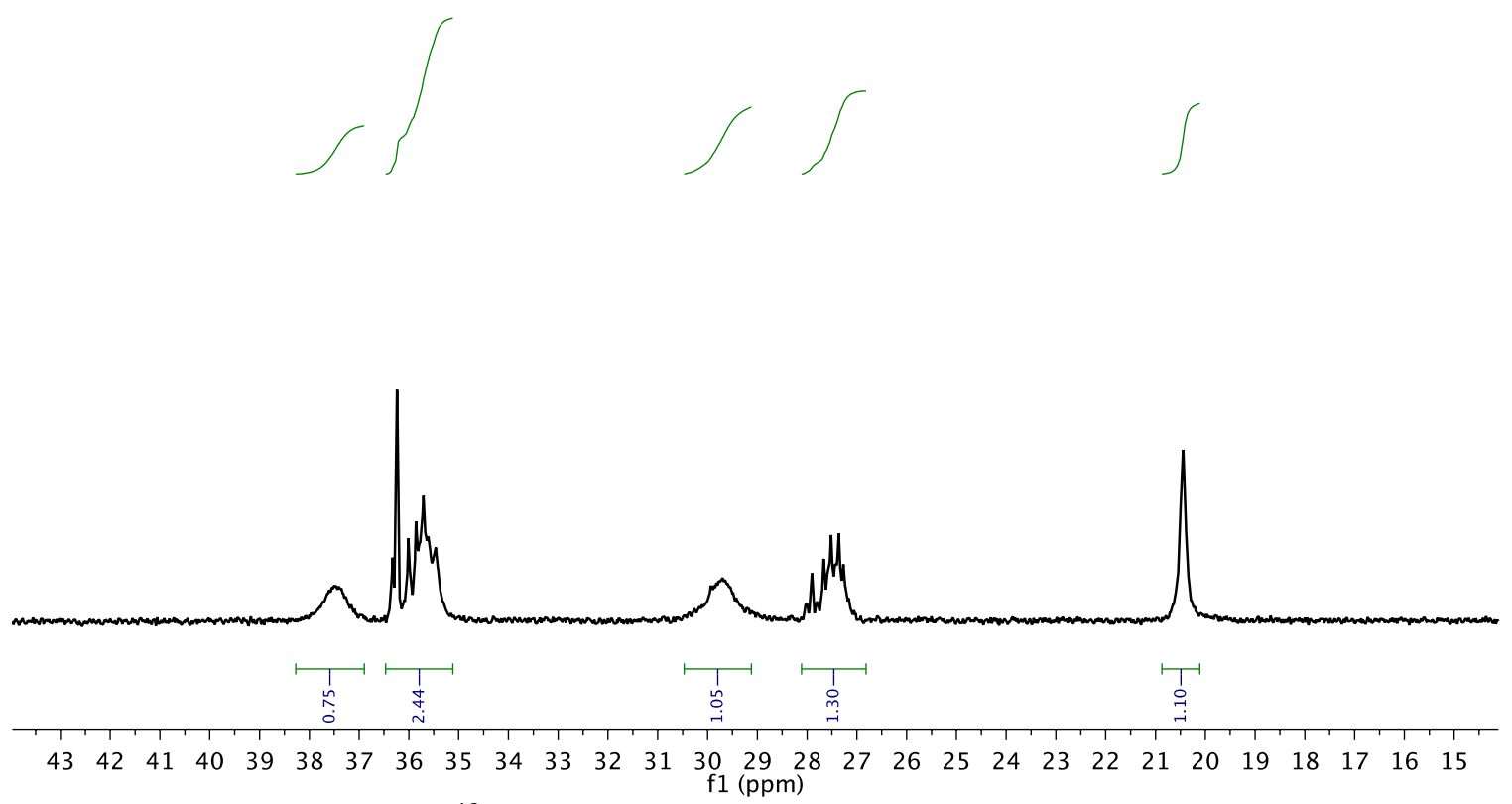

Figure S16. Quantitative ${ }^{13} \mathrm{C}-\mathrm{NMR}$ spectrum (aliphatic region) collected at $293 \mathrm{~K}$ of 1 methylbenzosuberan- $d_{n}$ with integrations. The unexpected number of peaks and integration values are likely due to fluxional processes in the ring. 
G. Establishment of syn / anti disposition of aliphatic protons in 1methyltetrahydronaphthalene.

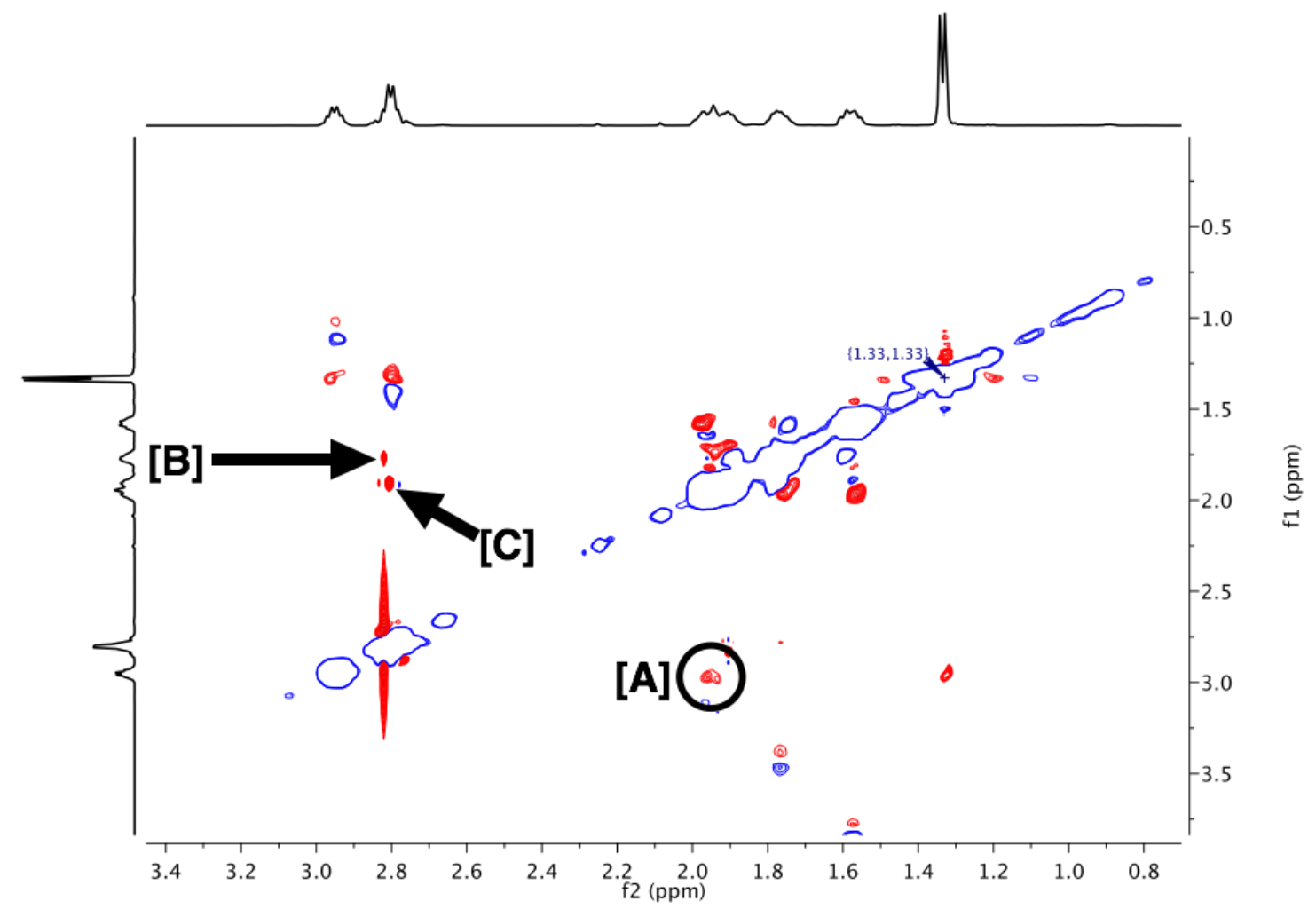

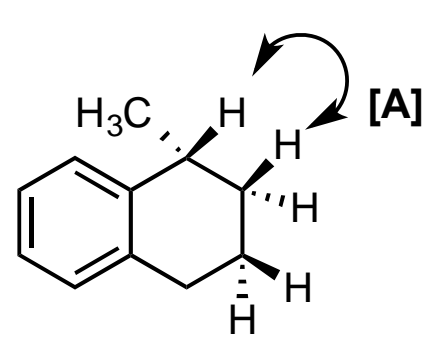

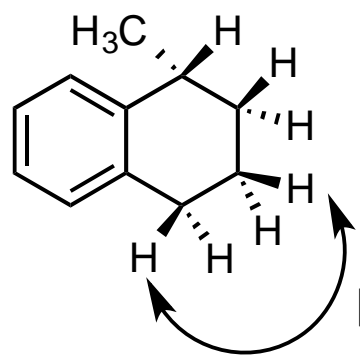

[B]

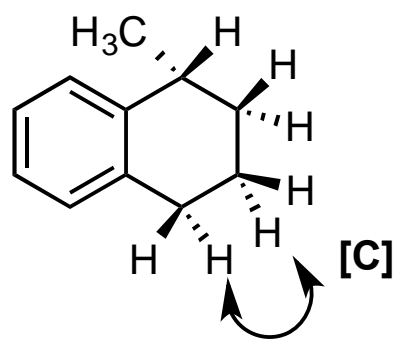

Figure S17. NOESY ${ }^{1} \mathrm{H}$ NMR spectrum of 1-methyltetralin (top) and some of the diagnostic through-space interactions of the aliphatic protons (bottom). Note that while separate cross peaks are observed at the diastereotopic protons of the 4-position, the spacing between the two signals is too close to determine unambiguously the position of deuterium incorporation, but is assigned by analogy with the 5-membered ring system (see below). 


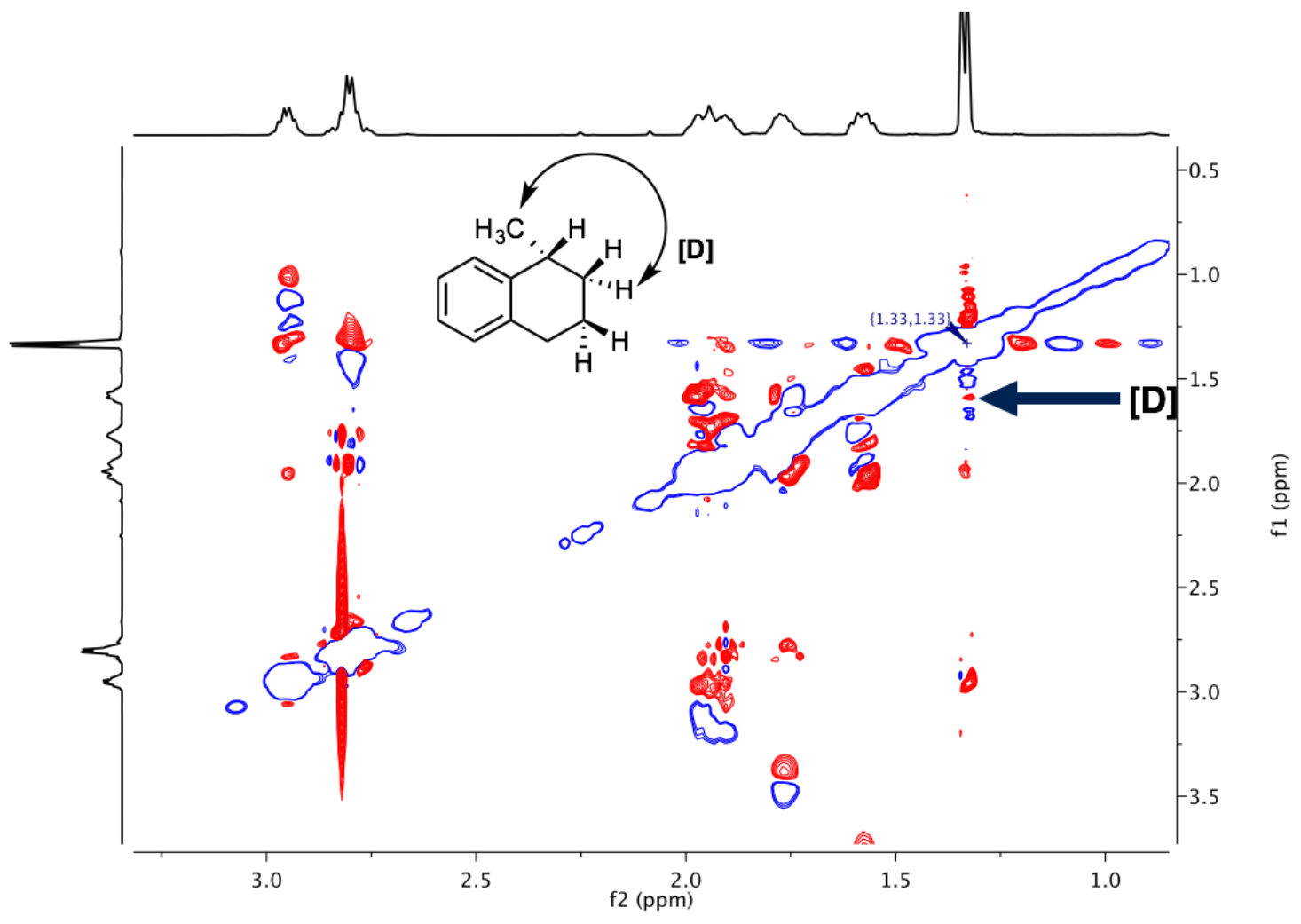

Figure S18. NOESY ${ }^{1} \mathrm{H}-\mathrm{NMR}$ spectrum of 1-methyltetralin one of the corresponding through-space interactions of the aliphatic protons. 


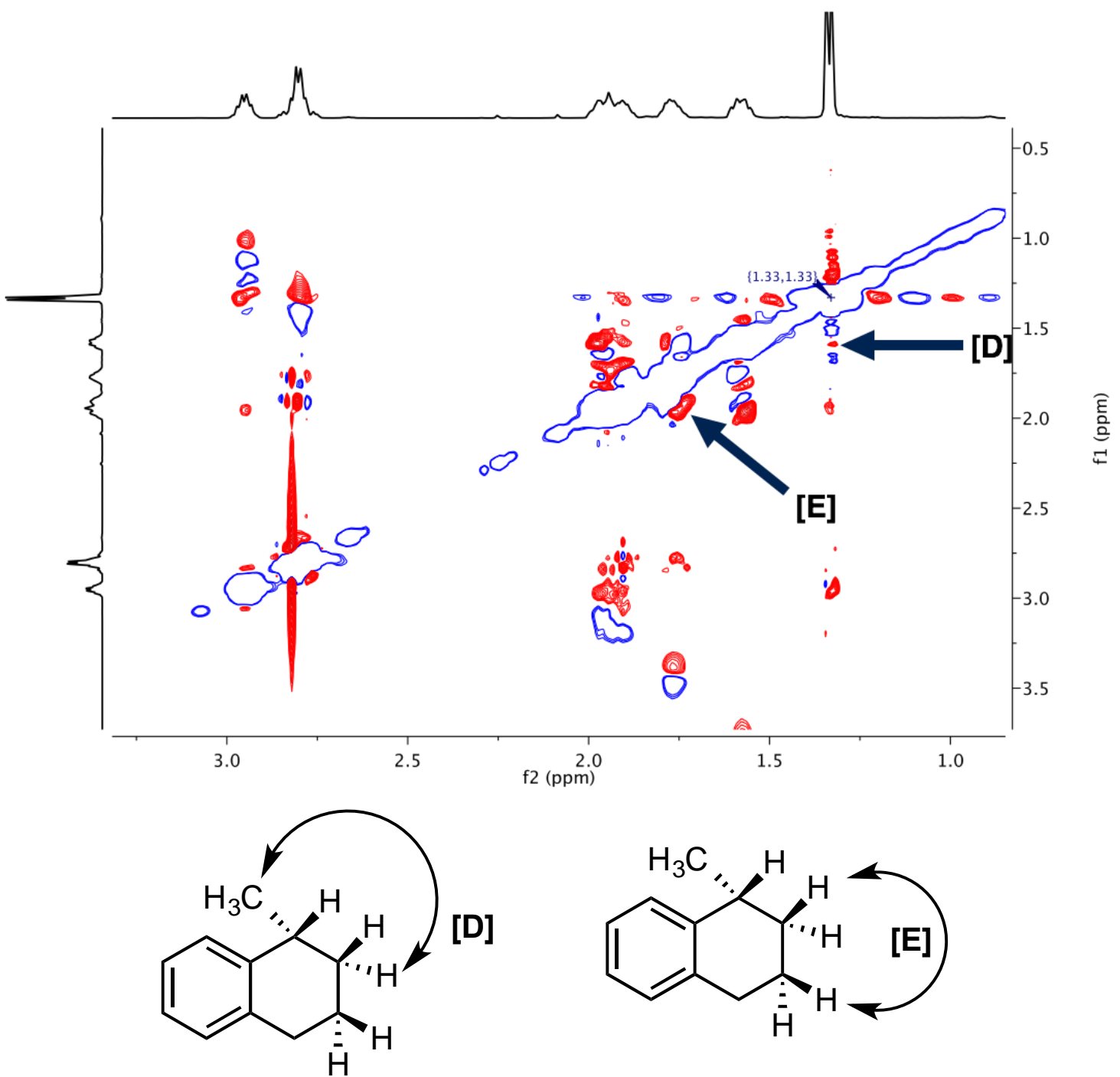

Figure S19. NOESY ${ }^{1} \mathrm{H}$-NMR spectrum of 1 -methyltetralin (top) and some of the corresponding through-space interactions of the aliphatic protons (bottom). 


\section{H. NMR spectra of 1-methyltetralin- $d_{4}$.}

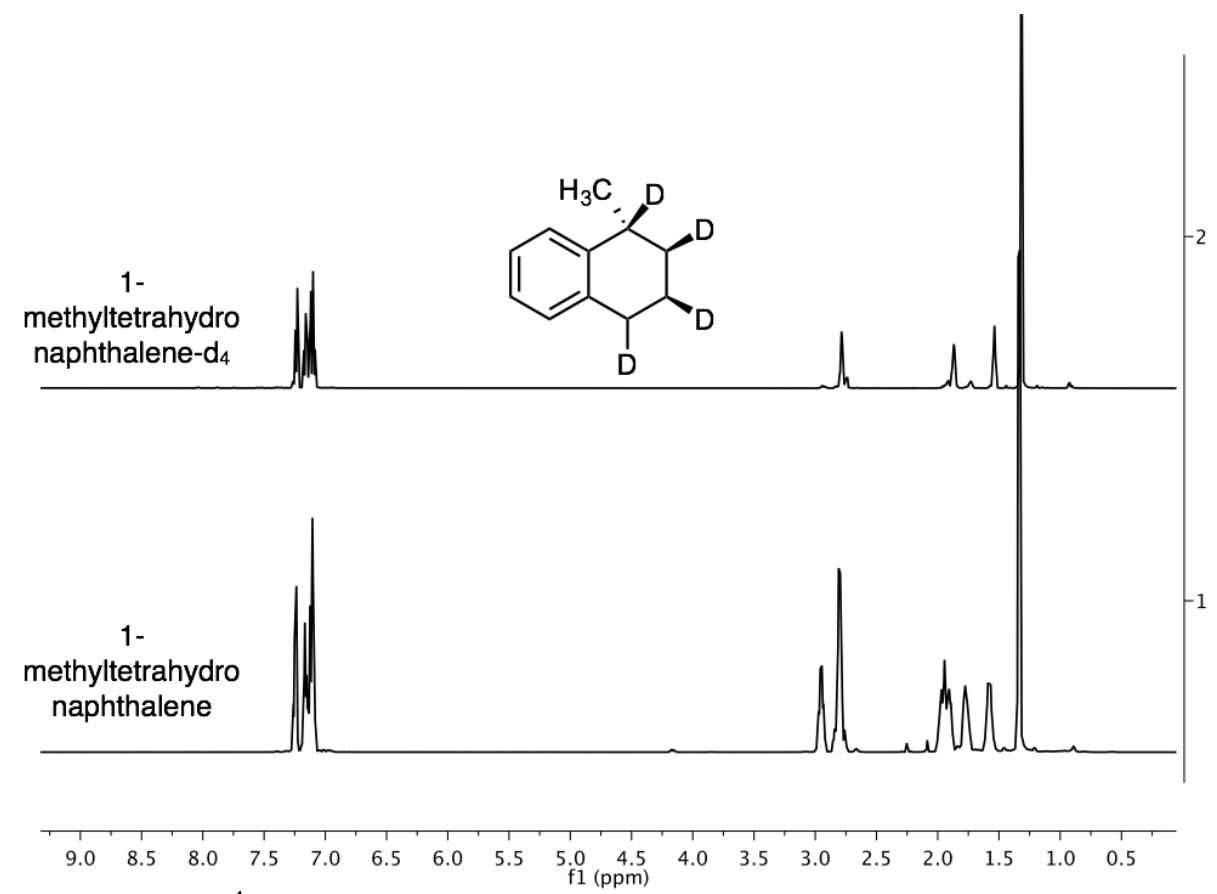

Figure S20. ${ }^{1} \mathrm{H}$-NMR spectrum of alkane products 1 -methyltetralin- $d_{4}$ (top) and 1methyltetralin.
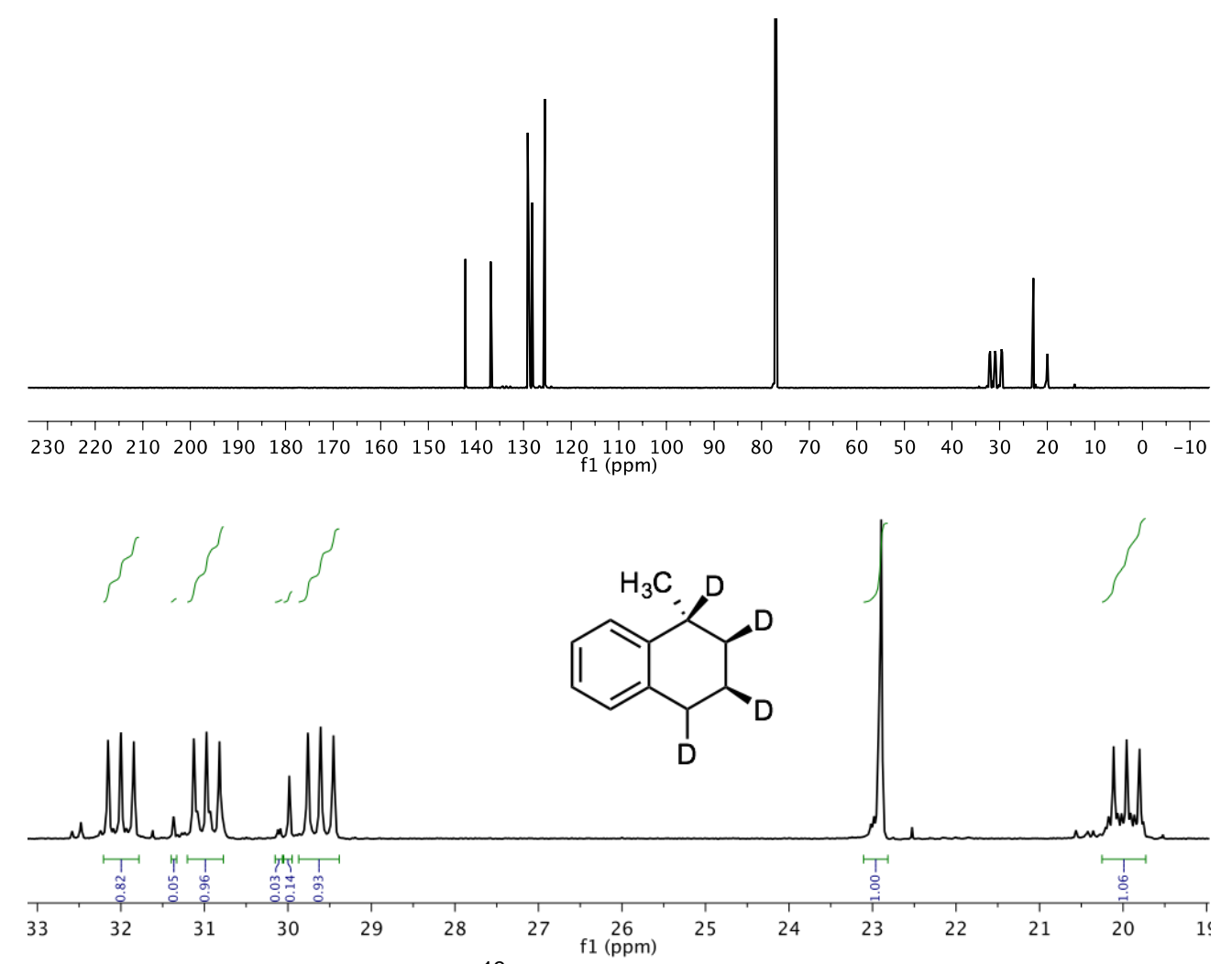

Figure S21. Full quantitative ${ }^{13} \mathrm{C}$ NMR spectrum of 1-methyltetralin- $d_{4}$ (top), and aliphatic region showing the five $\mathrm{sp}^{3}$ carbons (bottom). 


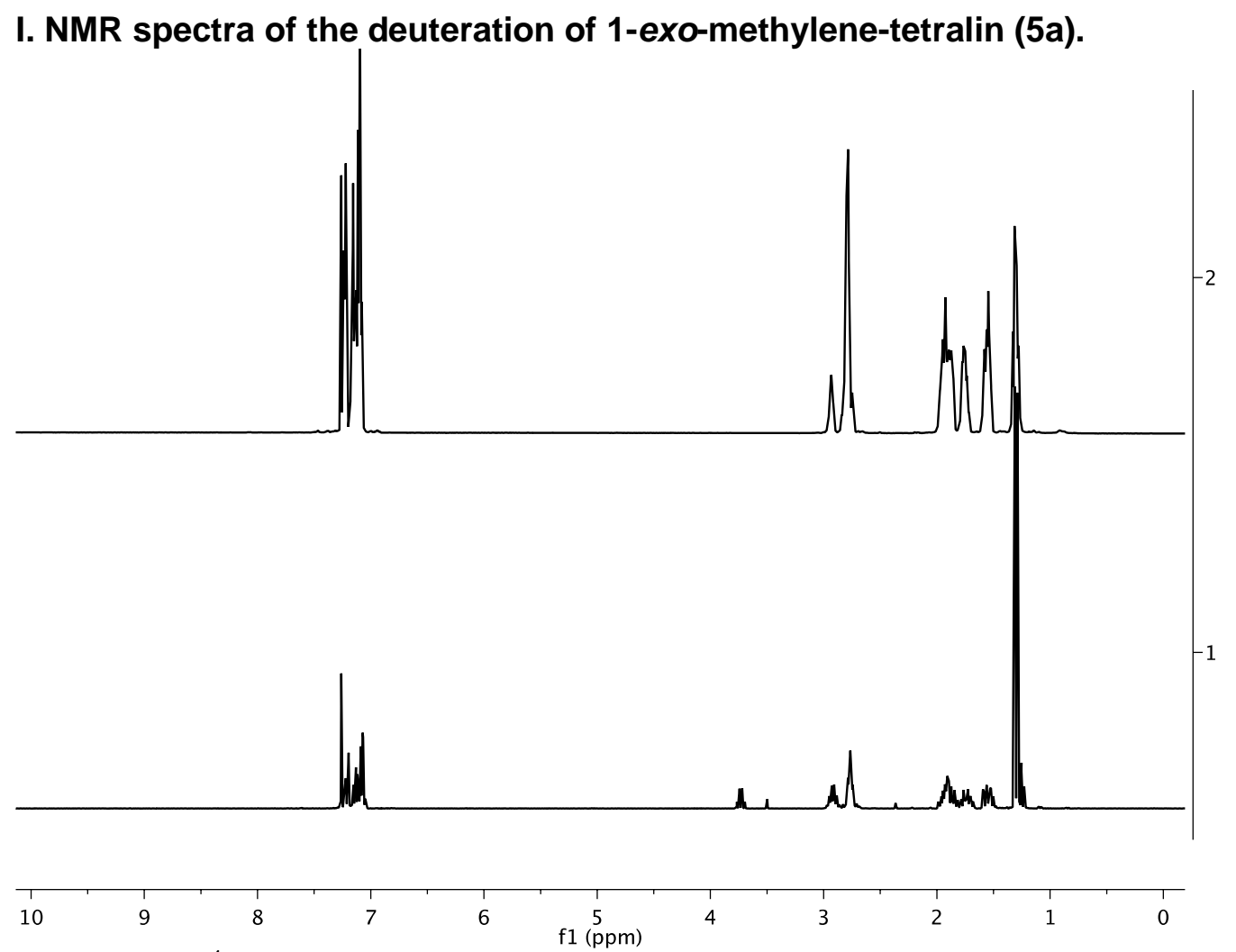

Figure S22. ${ }^{1} \mathrm{H}-\mathrm{NMR}$ spectra of alkane products 1-methyltetralin- $\mathrm{d}_{\mathrm{n}}$ (top) and all-protio 1-methyltetralin.
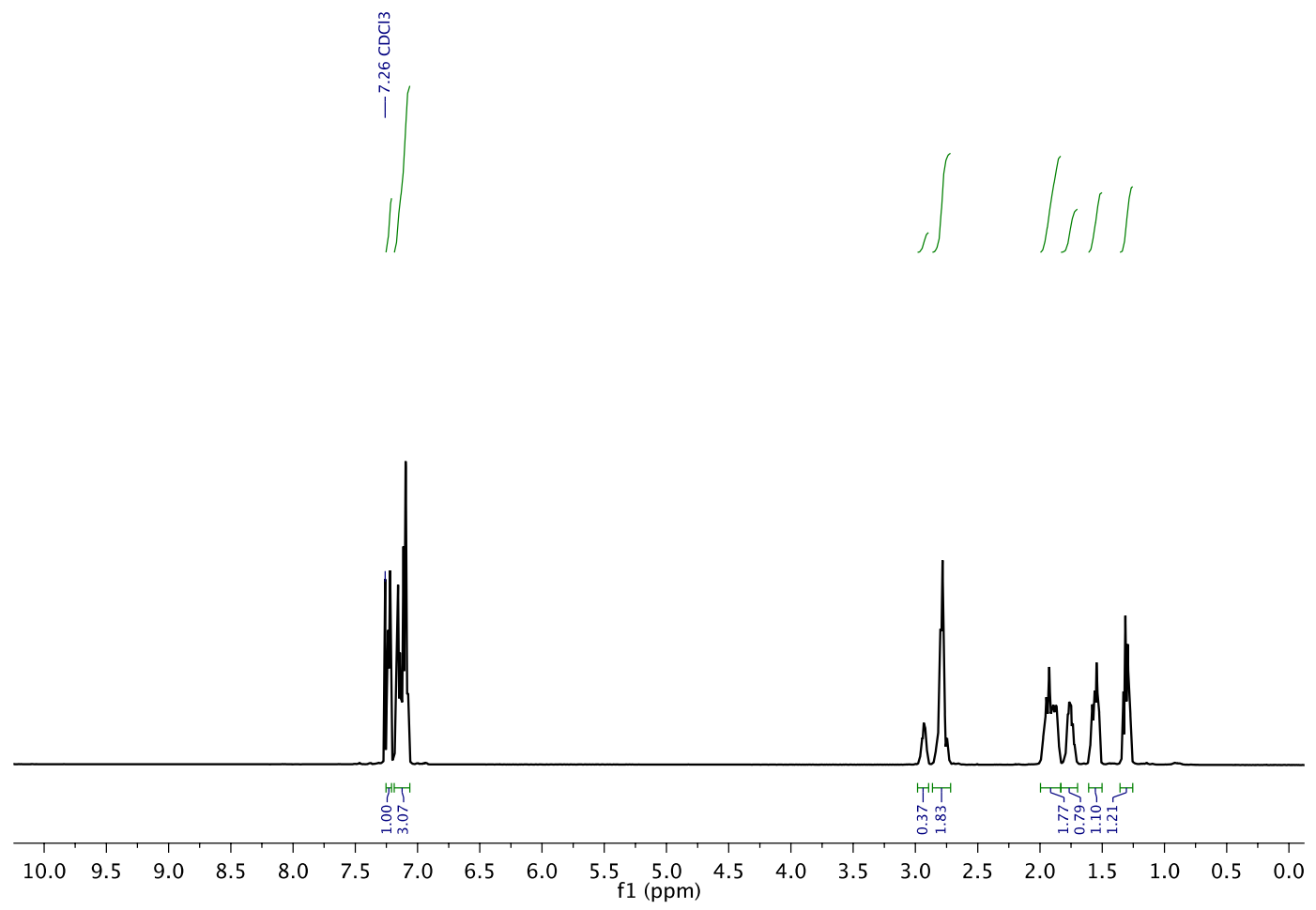

Figure S23. ${ }^{1} \mathrm{H}-\mathrm{NMR}$ spectra of alkane products 1-methyltetralin- $\mathrm{d}_{\mathrm{n}}$ (top) with integrations. 


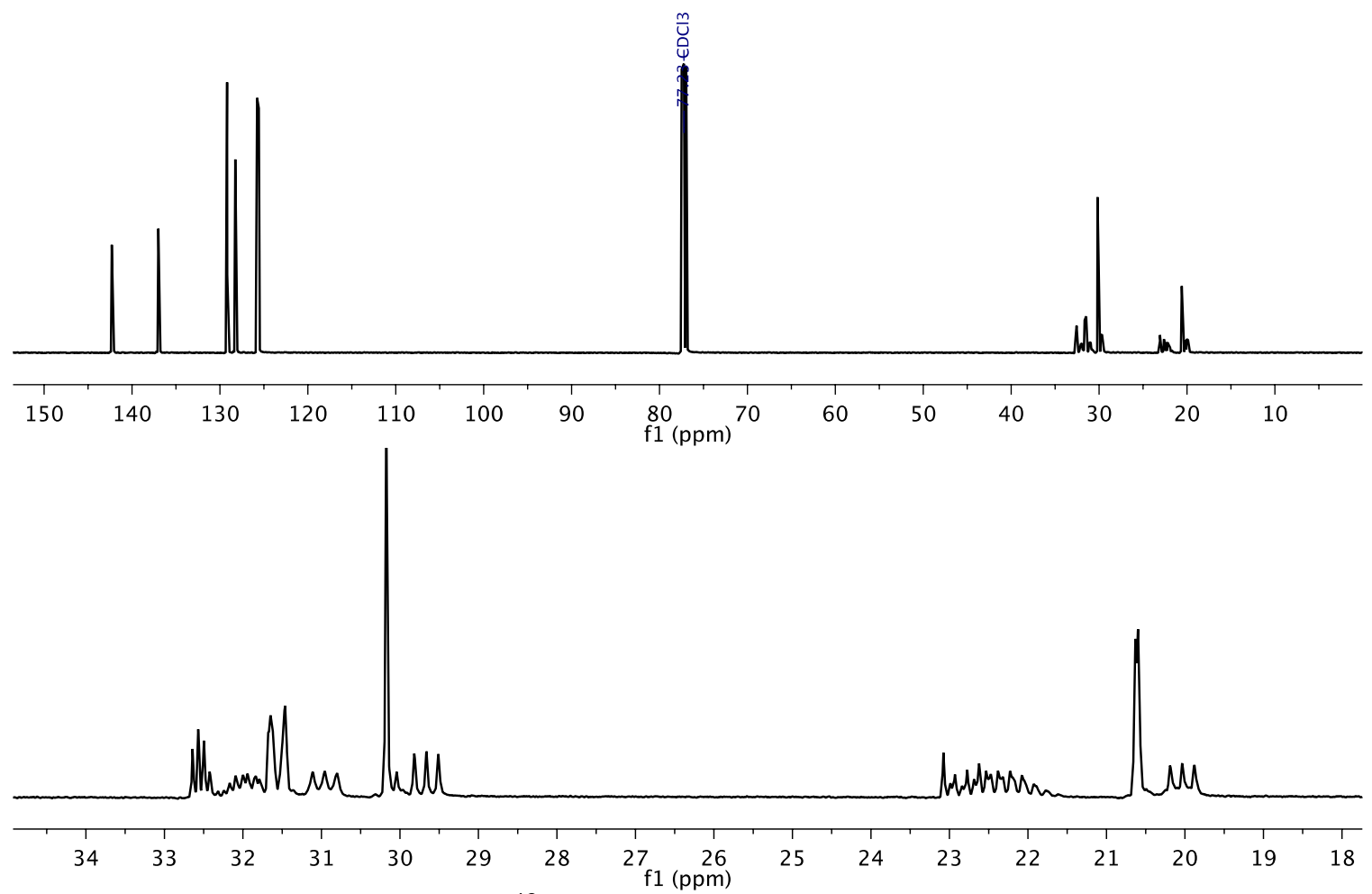

Figure S24. Full quantitative ${ }^{13} \mathrm{C}$ NMR spectrum of 1-methyltetralin- $d_{\mathrm{n}}$ (top), and aliphatic region showing the five $\mathrm{sp}^{3}$ carbons (bottom). 
J. Establishment of syn / anti disposition of aliphatic protons in 1-methylindane.

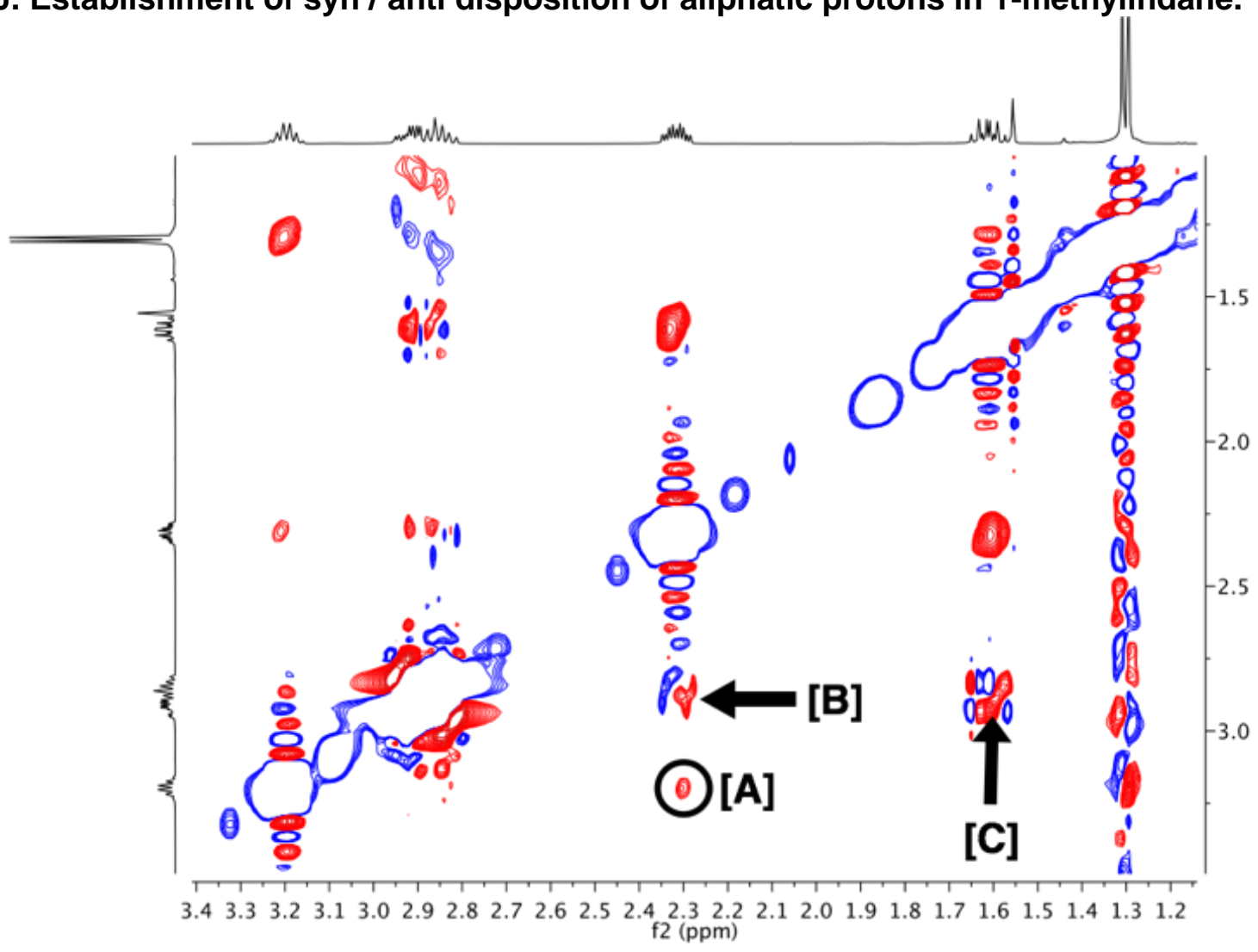<smiles>C[C@]12CCCC[Al]CC[C@H]1[C@H]2c1ccccc1</smiles><smiles>C[C@H]1c2ccccc2[C@H]1C=CCBr</smiles>

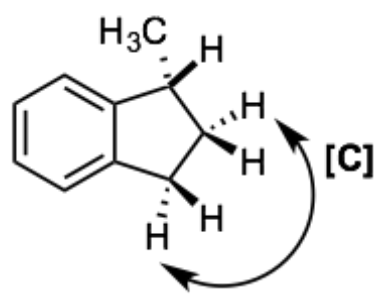

Figure S25. NOESY ${ }^{1} \mathrm{H}-\mathrm{NMR}$ spectrum of 1 -methylindane (top) and some of the diagnostic through-space interactions of the aliphatic protons (bottom). 
K. NMR spectra of the deuteration of 1-exo-methylene-indane (19a).

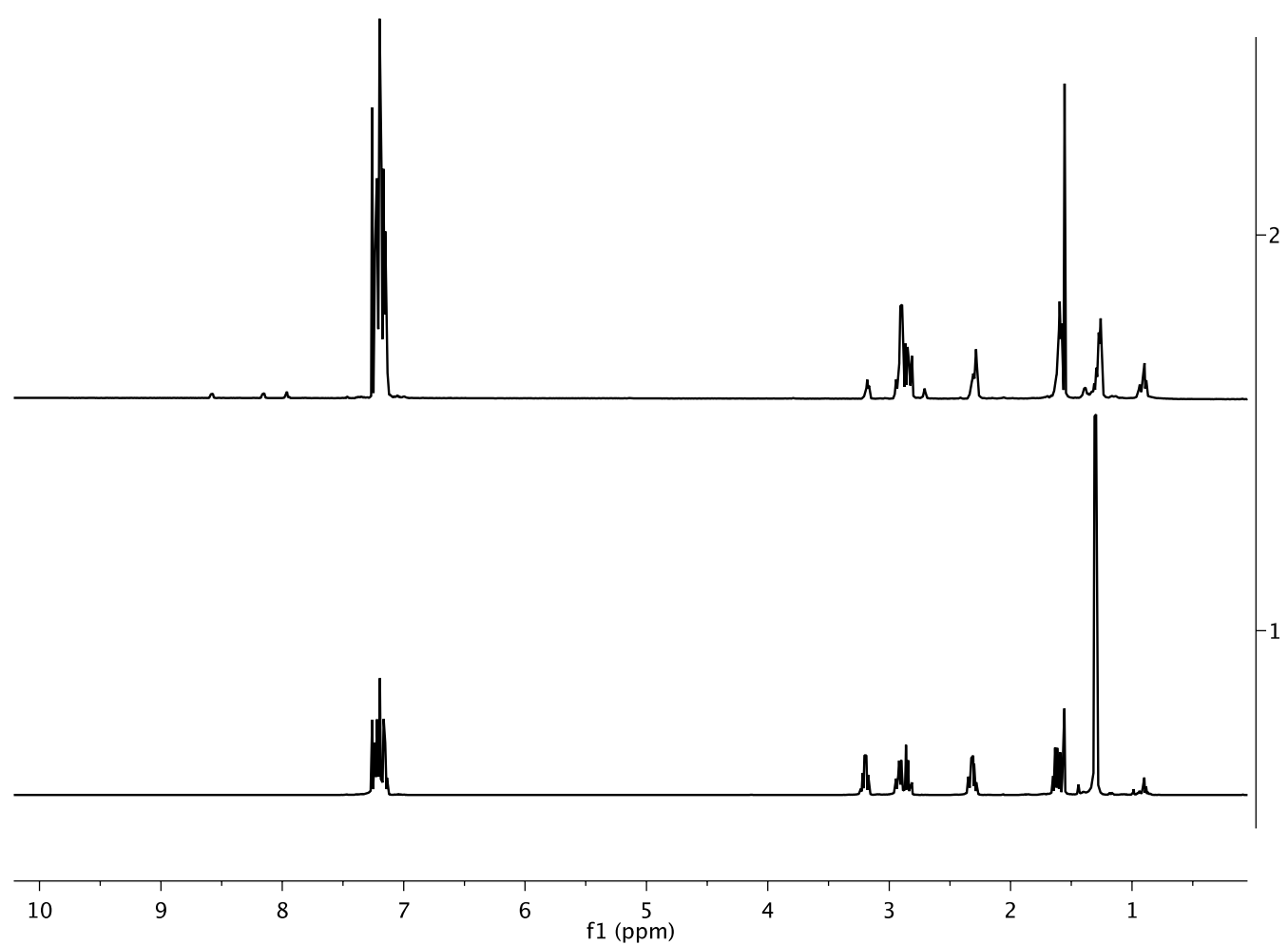

Figure S26. ${ }^{1} \mathrm{H}-\mathrm{NMR}$ spectra of 1 -methylindane- $\mathrm{d}_{\mathrm{n}}$ (top) and all-protio 1-methylindane (bottom).

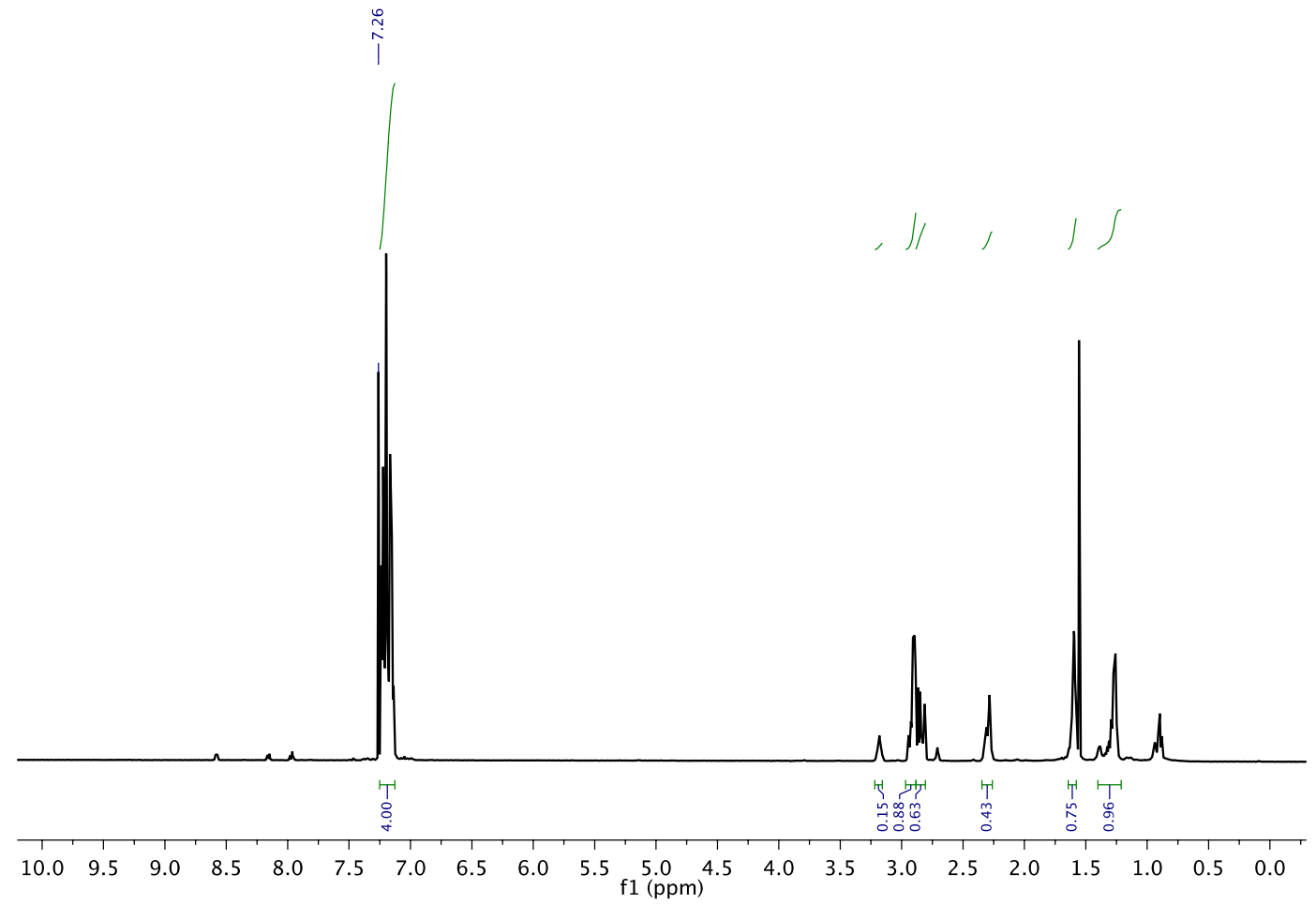

Figure S27. ${ }^{1} \mathrm{H}-\mathrm{NMR}$ spectrum of 1-methylindane- $\mathrm{d}_{\mathrm{n}}$ with integrations. 


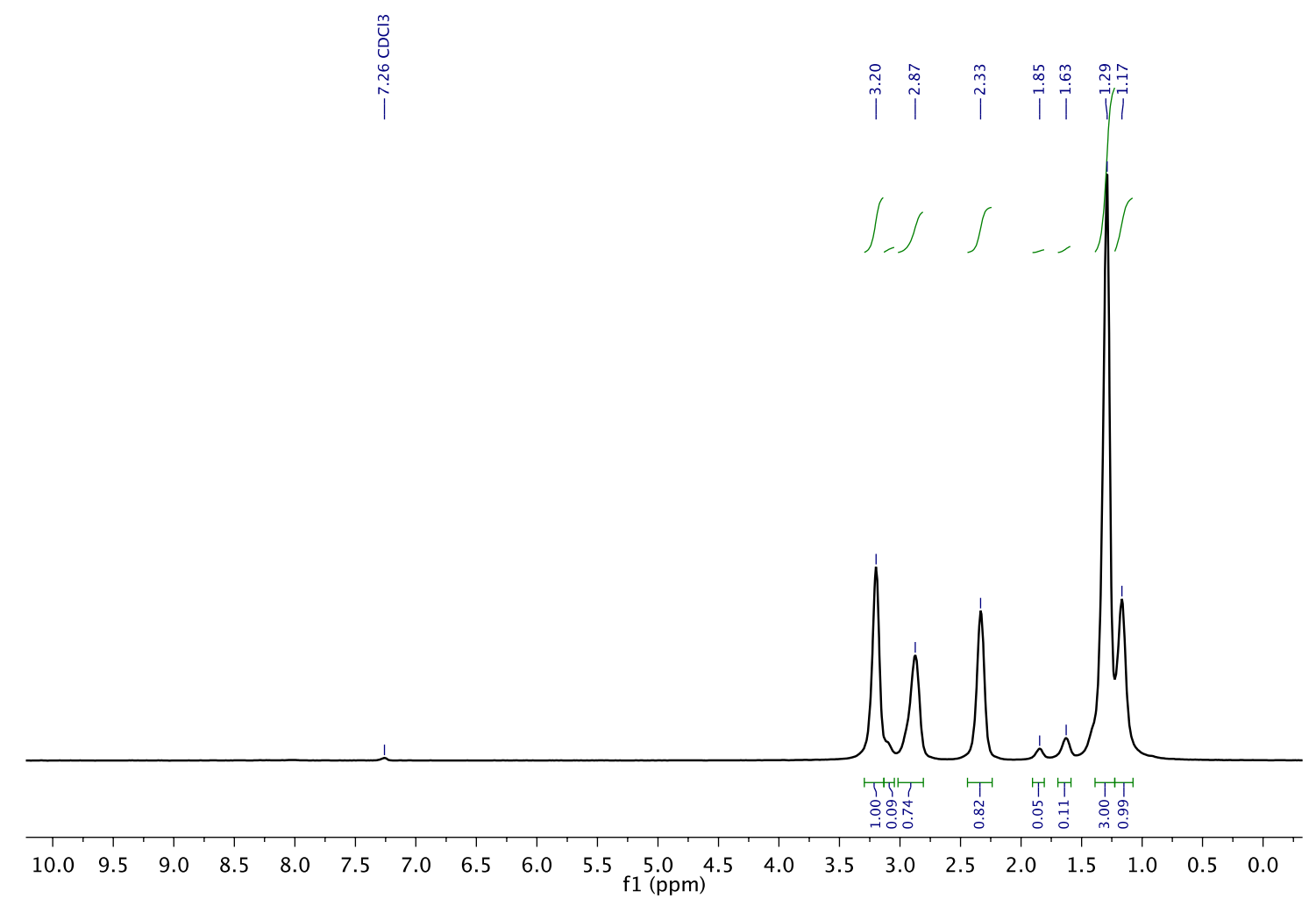

Figure S28. ${ }^{2} \mathrm{H}-\mathrm{NMR}$ spectrum of 1 -methylindane- $\mathrm{d}_{\mathrm{n}}$ with integrations establishing deuteration in the methyl position and in the ring.
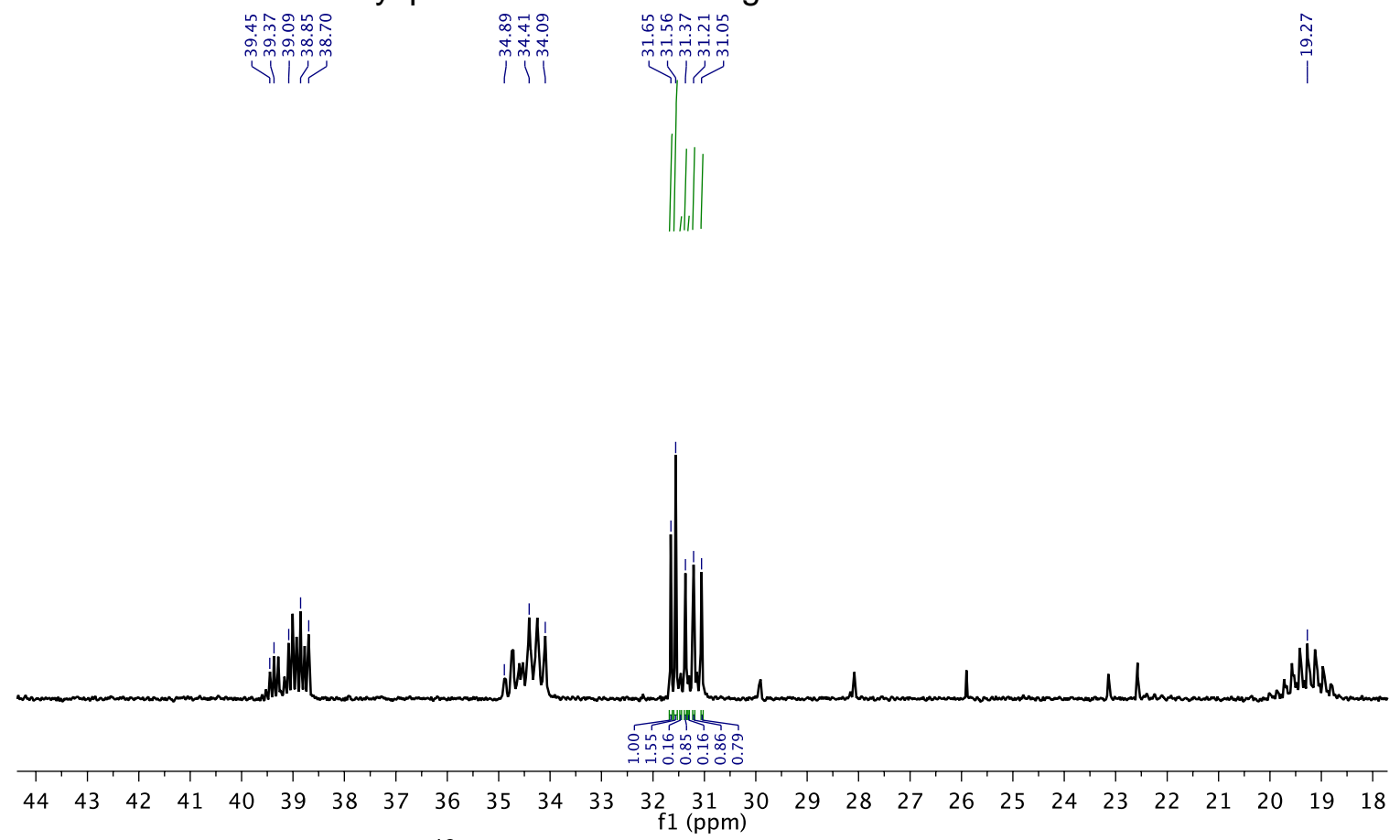

Figure S29. Quantitative ${ }^{13} \mathrm{C}-\mathrm{NMR}$ spectrum (aliphatic region) 1-methylindane- $\mathrm{d}_{\mathrm{n}}$ with some integrations. The spectrum contains a small quantity of free ligand from the catalyst. 
L. NMR spectra of the deuteration of 3-methyl-indene (19b).

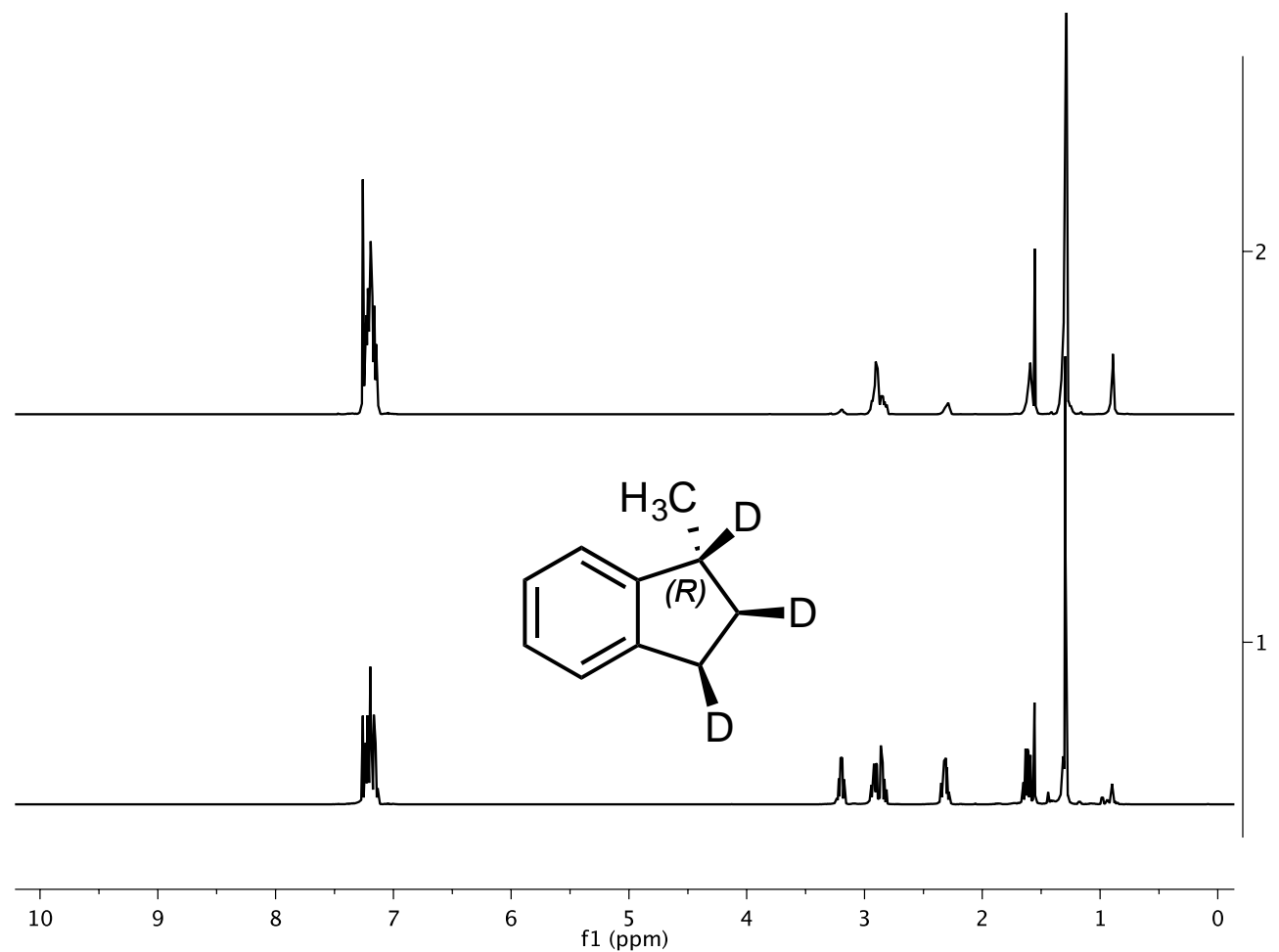

Figure S30. ${ }^{1} \mathrm{H}-\mathrm{NMR}$ spectra of 1-methylindane- $\mathrm{d}_{3}$ (top) and all-protio 1-methylindane (bottom).

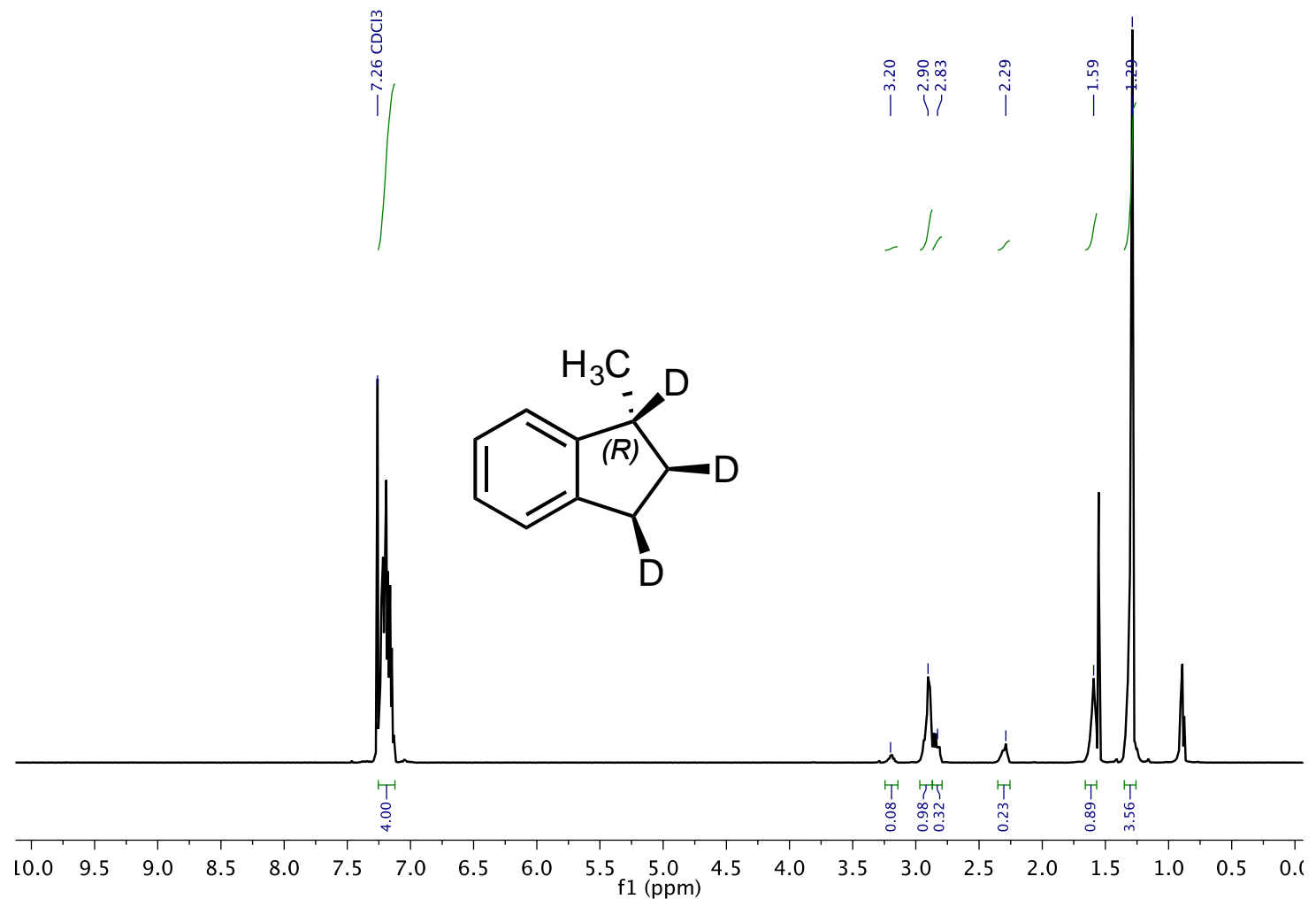

Figure S31. ${ }^{1} \mathrm{H}-\mathrm{NMR}$ spectrum of 1 -methylindane- $\mathrm{d}_{3}$ with integrations. 

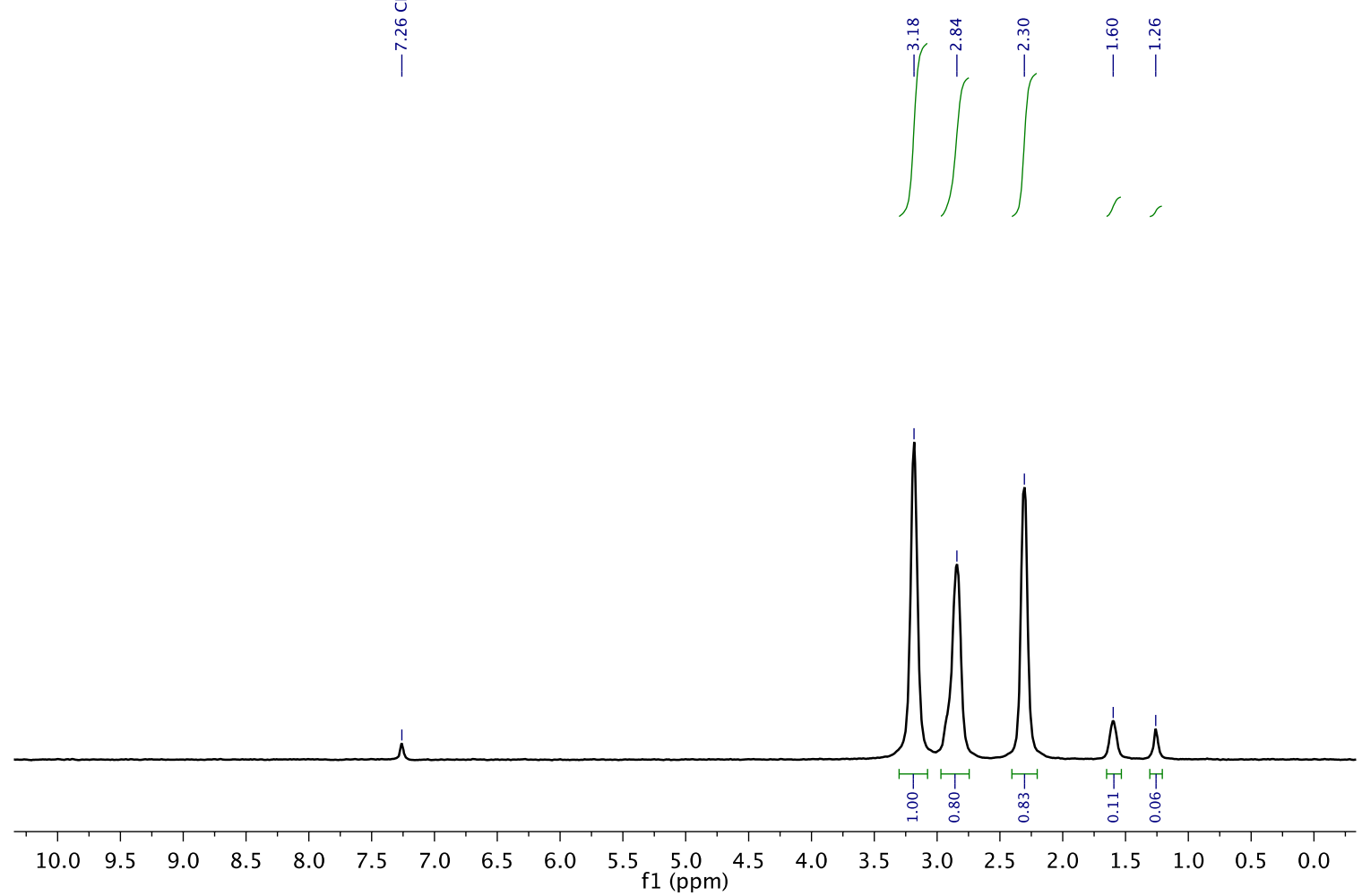

Figure S32. ${ }^{2} \mathrm{H}-\mathrm{NMR}$ spectrum of 1 -methylindane- $\mathrm{d}_{\mathrm{n}}$ with integrations establishing the $\mathrm{d}_{3}$-syn configuration in the aliphatic ring. The methyl group contains minimal deuterium. : in inim
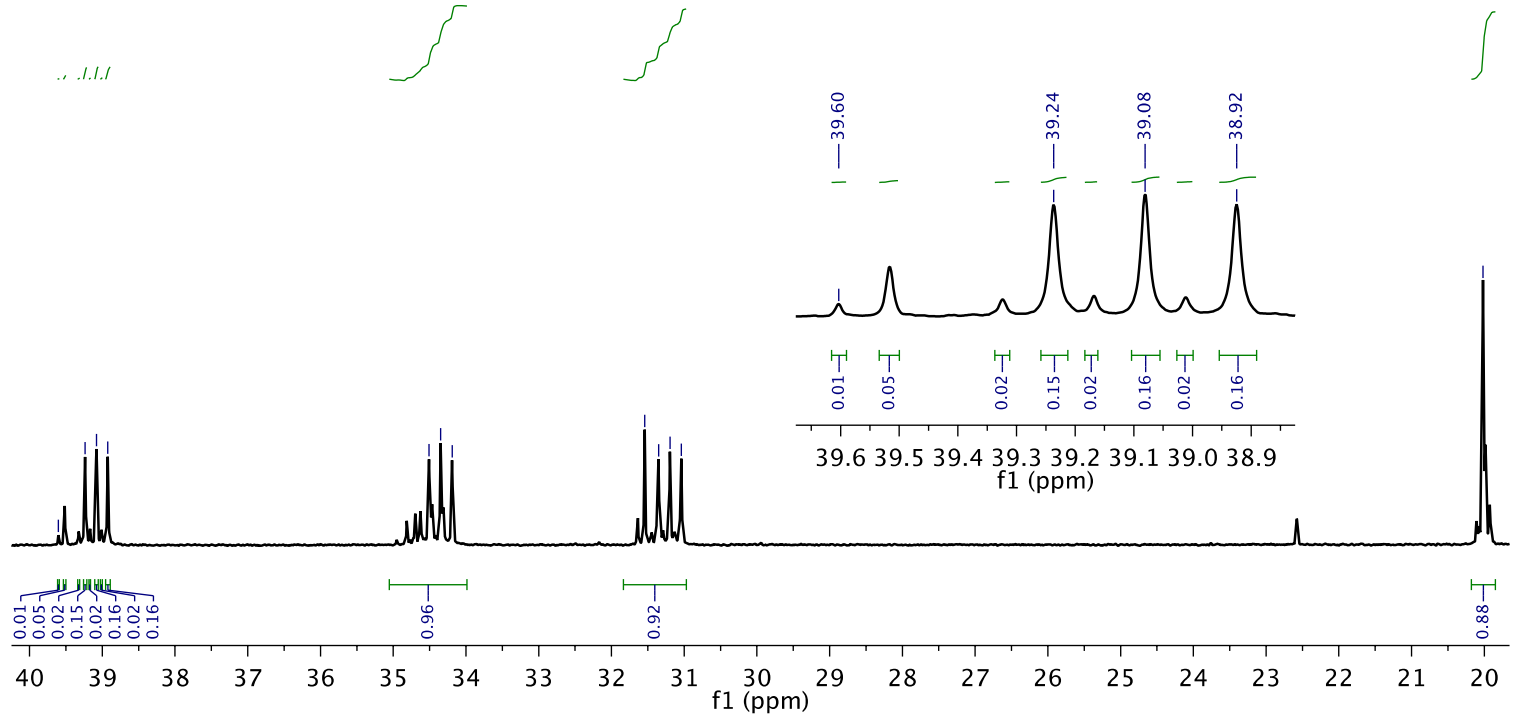

Figure S33. Quantitative ${ }^{13} \mathrm{C}-\mathrm{NMR}$ spectrum (aliphatic region) 1-methylindane- $\mathrm{d}_{3}$ with some integrations showing the deuterium incorporation in the aliphatic ring (both methylenes are predominantly [CHD]), while the methyl group is predominantly $\left[\mathrm{CH}_{3}\right]$. 
M. NMR spectra of the deuteration of $\alpha$-isopropylstyrene (21).

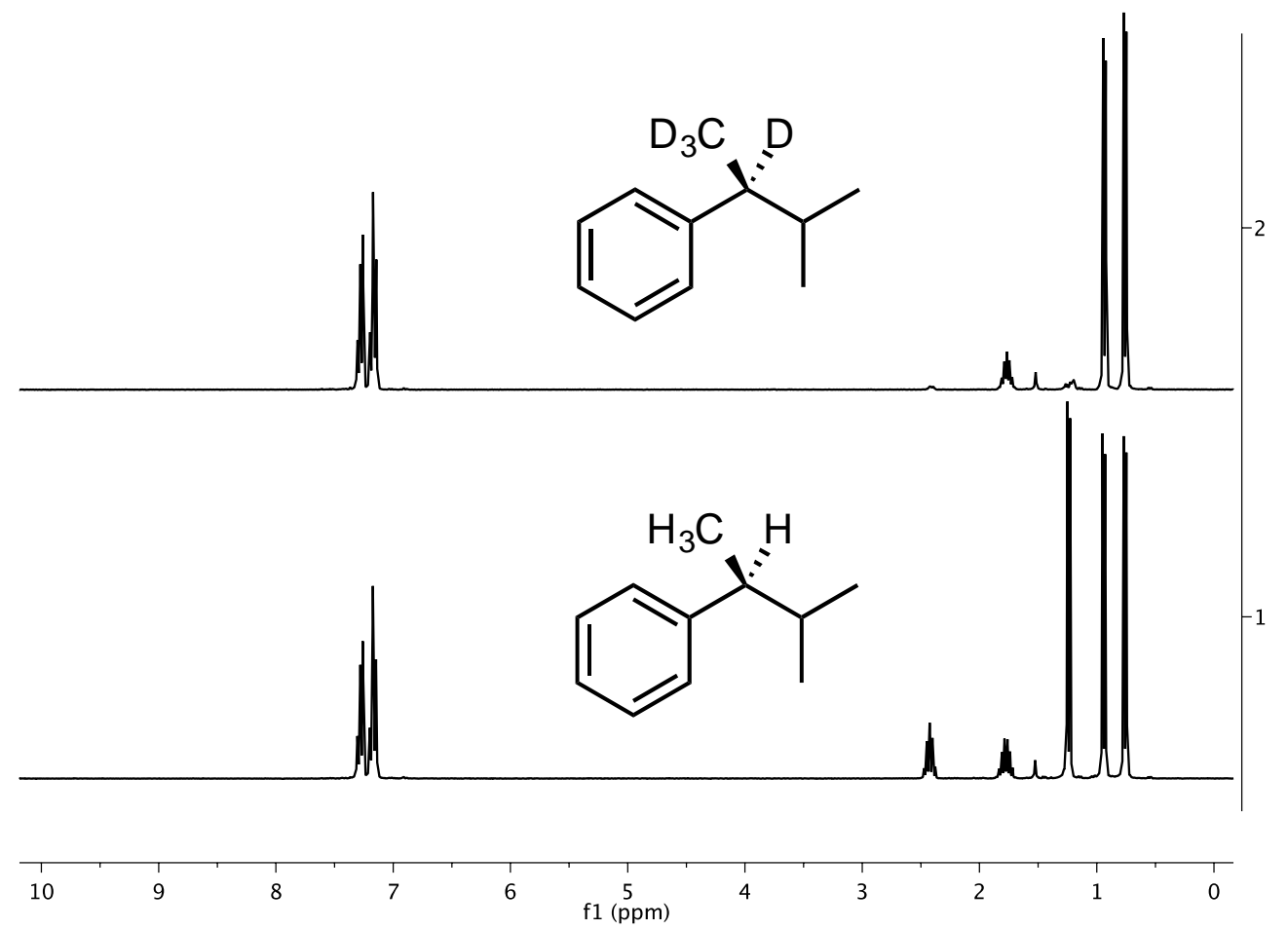

Figure S34. ${ }^{1} \mathrm{H}-\mathrm{NMR}$ spectra of 2-phenyl-3-methylbutane- $d_{4}$ (top) and all-protio 2phenyl-3-methylbutane (bottom).

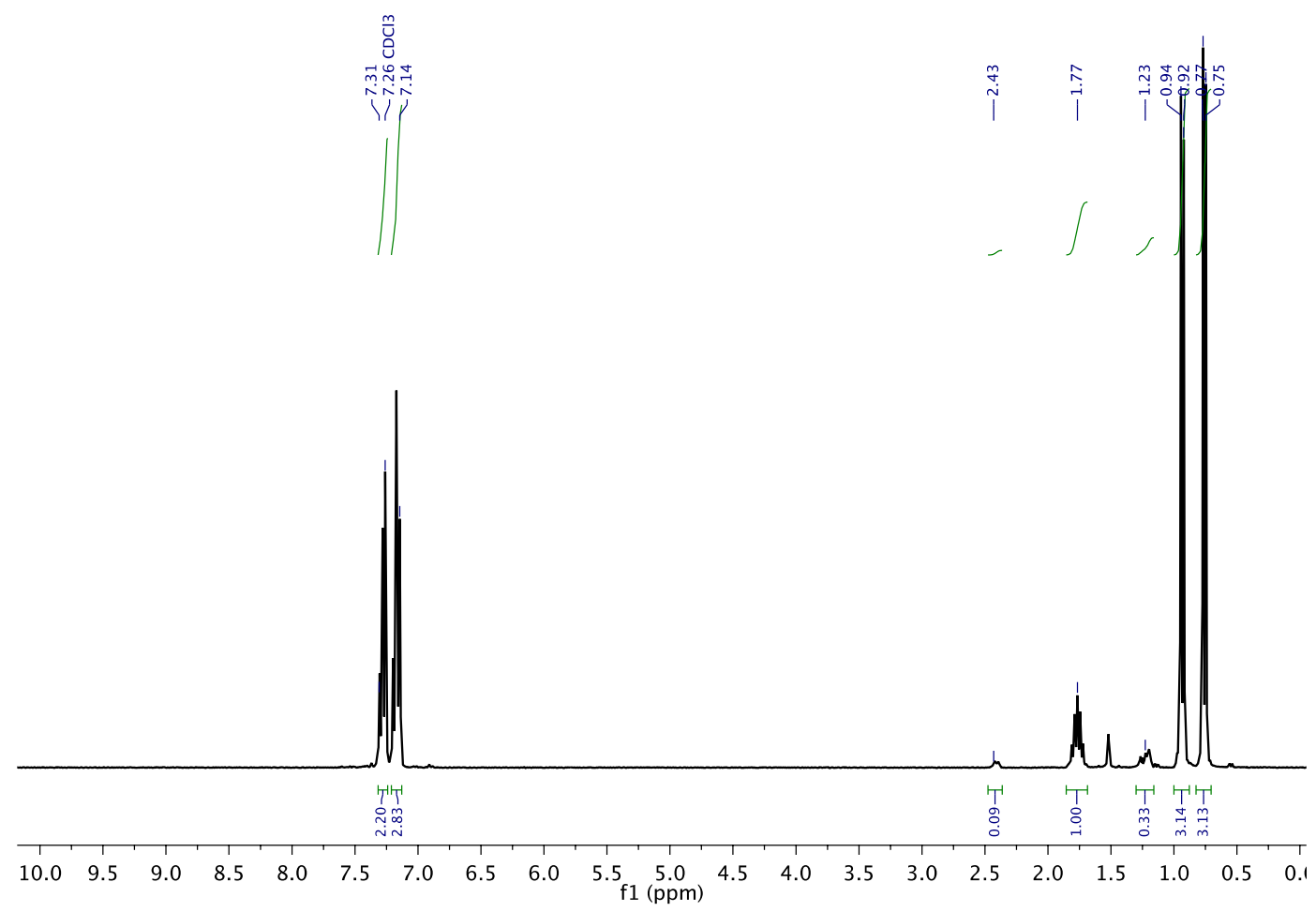

Figure S35. ${ }^{1} \mathrm{H}-\mathrm{NMR}$ spectrum of 2-phenyl-3-methylbutane- $d_{4}$ with integrations. 


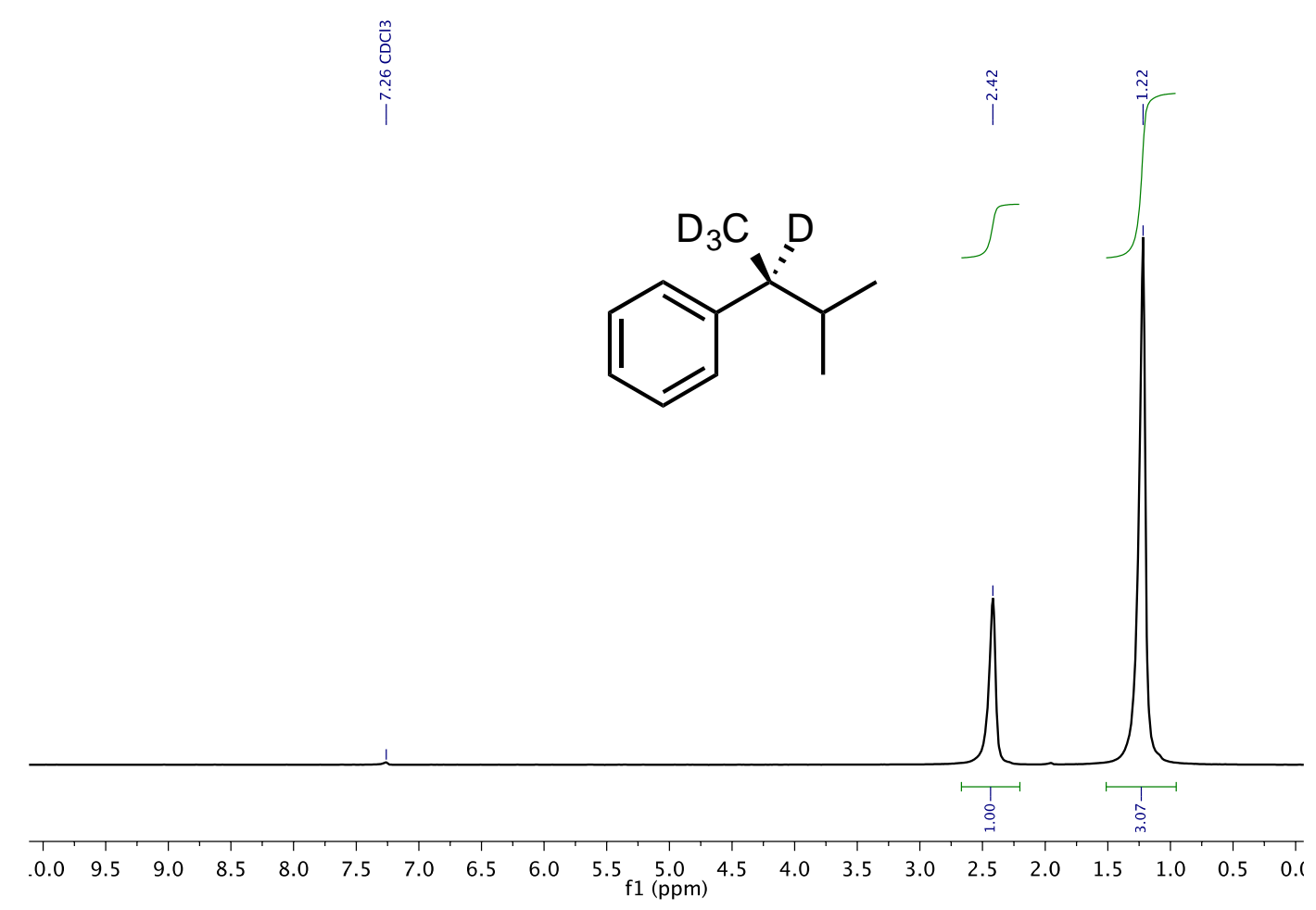

Figure S36. ${ }^{2} \mathrm{H}-\mathrm{NMR}$ spectrum of 2-phenyl-3-methylbutane- $d_{4}$ with integrations.
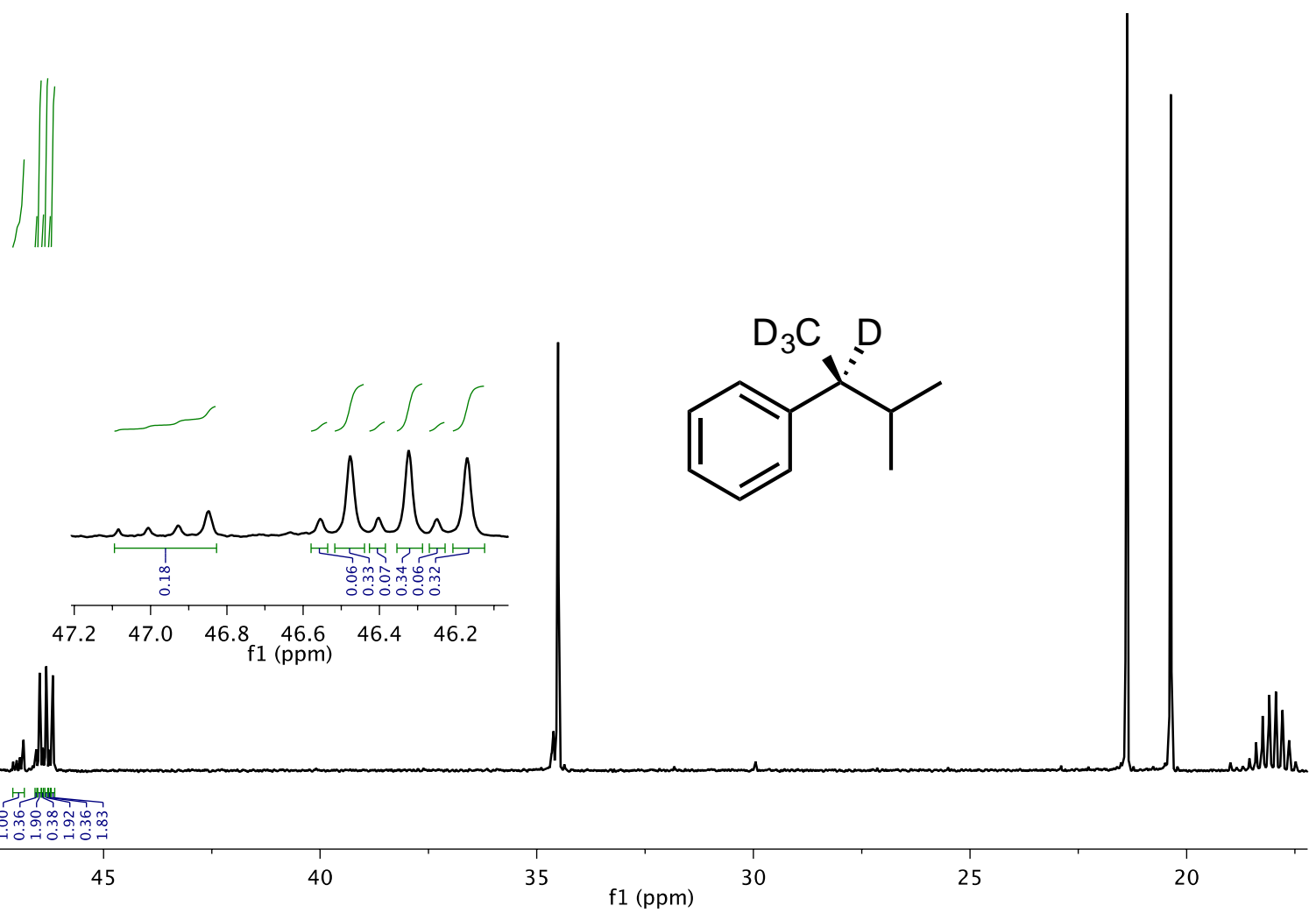

Figure S37. Quantitative ${ }^{13} \mathrm{C}-\mathrm{NMR}$ spectrum (aliphatic region) with some integrations showing 2-phenyl-3-methylbutane- $d_{4}$ as the predominant product. 


\section{Synthesis and characterization of (S)-CoH.}

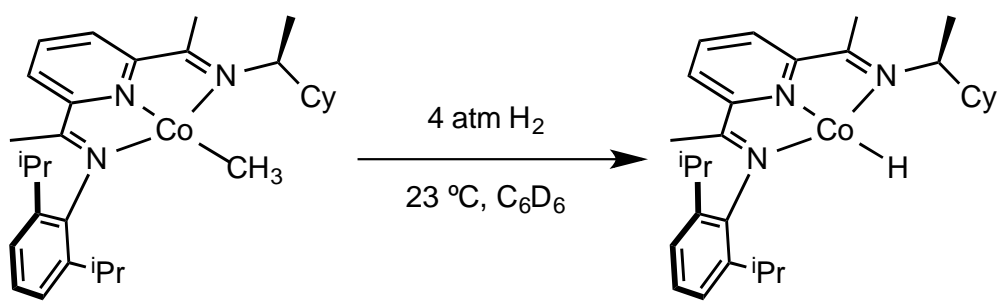

In a nitrogen-filled glovebox, a gas-tight J. Young NMR tube was charged with $0.015 \mathrm{~g}$ (0.03 mmol) of (S) $-\mathrm{CoCH}_{3}$ and $0.4 \mathrm{~mL} \mathrm{C}_{6} \mathrm{D}_{6}$. The tube was attached to the high-vacuum line and then its contents were frozen in liquid nitrogen. Following evacuation of the headspace, the vessel was pressurized with 1 atm of hydrogen gas at $77 \mathrm{~K}$ and resealed. Upon warming to room temperature (at which point the pressure is $\sim 4 \mathrm{~atm}$ ), the tube was for 10 minutes at $25 \stackrel{\circ}{ } \mathrm{C}$ at which point analysis of the reaction progress was determined by ${ }^{1} \mathrm{H}$-NMR. If necessary, the hydrogen atmosphere can be refreshed to reach full conversion. (S)-CoH is stable under an $\mathrm{N}_{2}$ atmosphere for hours at room temperature, but under vacuum will convert to (S)-Co-CM. Crystals suitable for X-ray diffraction were obtained by repeating this procedure using $0.050 \mathrm{~g}(\mathrm{~S})-\mathrm{CoCH}_{3}$ in a concentrated pentane solution and letting the reaction mixture stand at room temperature for 24 hours until purple crystals of (S)-CoH formed.
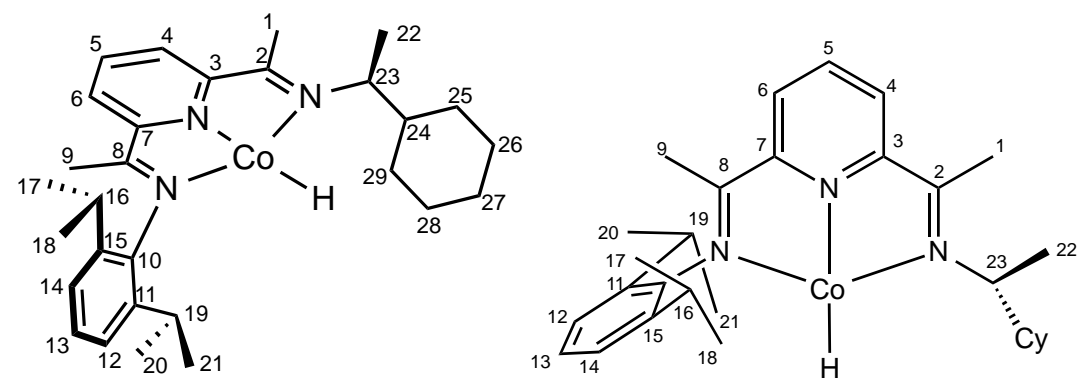

${ }^{1} \mathrm{H}$ NMR (500 MHz, $\left.\mathrm{CDCl}_{3}, 23{ }^{\circ} \mathrm{C}\right): \delta-2.48\left(\mathrm{~s}, 3 \mathrm{H}, 9-\mathrm{CH}_{3}\right),-0.13\left(\mathrm{~s}, 3 \mathrm{H}, 1-\mathrm{CH}_{3}\right), 0.34(\mathrm{~d}$, ${ }^{3} J_{\mathrm{HH}}=6.5 \mathrm{~Hz}, 3 \mathrm{H}, 18$ - or $21-\mathrm{CH}_{3}$ ), 0.35-0.41 (overlapping $\mathrm{m}, 1 \mathrm{H}$, cyclohexyl $\mathrm{CH}$ ), 0.73 $\left(\mathrm{d},{ }^{3} \mathrm{~J}_{\mathrm{HH}}=6.5 \mathrm{~Hz}, 3 \mathrm{H}, 18-\right.$ or $\left.21-\mathrm{CH}_{3}\right), 0.84-0.97\left(\mathrm{~m}, 2 \mathrm{H}\right.$, cyclohexyl 27-CH $\left.\mathrm{C}_{2}\right), 1.06-1.23$ (overlapping m, 4H, cyclohexyl $\mathrm{CH}$ ), $1.25\left(\mathrm{~d},{ }^{3} \mathrm{~J}_{\mathrm{HH}}=7.0 \mathrm{~Hz}, 3 \mathrm{H}, 17-\right.$ or $\left.20-\mathrm{CH}_{3}\right), 1.28(\mathrm{~d}$, ${ }^{3} J_{\mathrm{HH}}=7.0 \mathrm{~Hz}, 3 \mathrm{H}, 17-$ or $\left.20-\mathrm{CH}_{3}\right), 1.36\left(\mathrm{~d},{ }^{3} J_{\mathrm{HH}}=9.4 \mathrm{~Hz}, 1 \mathrm{H}\right.$, cyclohexyl $\left.\mathrm{CH}\right), 1.42-1.46$ 
$(\mathrm{m}, 1 \mathrm{H}$, cyclohexyl $\mathrm{CH}), 1.49\left(\mathrm{~d},{ }^{3} \mathrm{~J}_{\mathrm{HH}}=6.2 \mathrm{~Hz}, 3 \mathrm{H}, 22-\mathrm{CH}_{3}\right), 1.66(\mathrm{~m}, 1 \mathrm{H}$, cyclohexyl $\mathrm{CH}), 2.06\left(\mathrm{~d},{ }^{3} \mathrm{~J}_{\mathrm{HH}}=12.0 \mathrm{~Hz}, 1 \mathrm{H}\right.$, cyclohexyl CH), 3.38 (sept, ${ }^{3} J_{\mathrm{HH}}=6.5 \mathrm{~Hz}, 1 \mathrm{H}, 16-$ or 19-CH), 3.67 (sept, ${ }^{3} J_{\mathrm{HH}}=6.9 \mathrm{~Hz}, 1 \mathrm{H}, 16-$ or $\left.19-\mathrm{CH}\right), 5.35(\mathrm{~m}, 1 \mathrm{H}, 23-\mathrm{CH}), 7.21\left(\mathrm{~d},{ }^{3} \mathrm{~J}_{\mathrm{HH}}\right.$ $=7.7 \mathrm{~Hz}, 6-\mathrm{CH}), 7.61\left(\mathrm{~d},{ }^{3} \mathrm{~J}_{\mathrm{HH}}=7.7 \mathrm{~Hz}, 12\right.$ - or $\left.14-\mathrm{CH}\right), 7.68\left(\mathrm{~d},{ }^{3} \mathrm{~J}_{\mathrm{HH}}=7.7 \mathrm{~Hz}, 12-\right.$ or $14-$ $\mathrm{CH}), 7.74$ (apparent t, $\left.{ }^{3} \mathrm{~J}_{\mathrm{HH}}=7.7 \mathrm{~Hz}, 13-\mathrm{CH}\right), 7.84\left(\mathrm{~d},{ }^{3} \mathrm{~J}_{\mathrm{HH}}=7.6 \mathrm{~Hz}, 4-\mathrm{CH}\right), 10.87$ (apparent t, $\left.{ }^{3} \mathrm{~J}_{\mathrm{HH}}=7.6 \mathrm{~Hz}, 5-\mathrm{CH}\right) \cdot\left\{{ }^{1} \mathrm{H}\right\}^{13} \mathrm{C} \mathrm{NMR}\left(126 \mathrm{MHz}, \mathrm{CDCl}_{3}, 23{ }^{\circ} \mathrm{C}\right): \delta 17.01$ (22$\mathrm{CH}_{3}$ ), $23.25\left(1-\mathrm{CH}_{3}\right), 23.29$ (17-, 18-, 20-, or 21- $\mathrm{CH}_{3}$ ), 23.55 (overlapping, 17-, 18-, 20-, or 21- $\mathrm{CH}_{3}$ ), 23.55 (overlapping, 17-, 18-, 20-, or 21- $\left.\mathrm{CH}_{3}\right), 23.86$ (17-, 18-, 20-, or $21-$ $\mathrm{CH}_{3}$ ), $26.38\left(9-\mathrm{CH}_{3}\right), 26.50$ (cyclohexyl $\mathrm{CH}_{2}$ ), 26.65 (cyclohexyl $\mathrm{CH}_{2}$ ), 27.19 (cyclohexyl $\mathrm{CH}_{2}$ ), 29.58 (16- or 19-CH), 29.61 (16- or 19-CH), 30.36 (cyclohexyl $\mathrm{CH}_{2}$ ), 32.01 (cyclohexyl $\left.\mathrm{CH}_{2}\right), 43.33(24-\mathrm{CH}), 71.18(23-\mathrm{CH}), 117.17(5-\mathrm{CH}), 123.60(6-\mathrm{CH}), 123.87$ (4- $\mathrm{CH}), 124.44$ (12- or $14-\mathrm{CH}), 124.85$ (12- or $14-\mathrm{CH}), 126.86$ (13-CH), 139.87 (11- or 15-C), 140.28 (11- or 15-C), 153.99 (7-C), 158.53 (3-C), 162.62 (10-C), 164.51 (8- $\left.C_{\text {imine }}\right)$, $168.94\left(2-C_{\text {imine }}\right)$.

\section{Grignard reagent additions to (S)-CoCl.}

\section{A. Synthesis of Grignard reagents.}

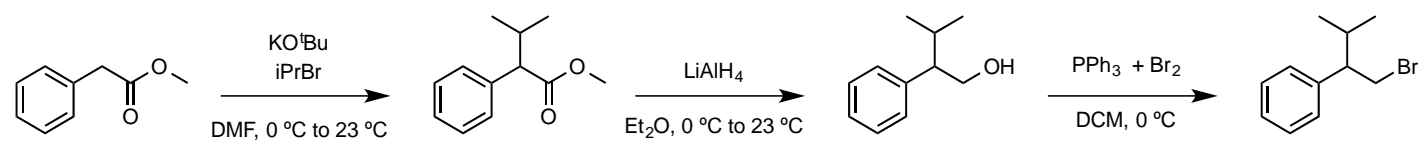

2-phenyl-3-methyl-1-butanol was prepared according to literature procedures and ${ }^{1} \mathrm{H}$ and ${ }^{13} \mathrm{C}$ NMR spectra are consistent with previously reported data. ${ }^{50}$ The preparation of 1-bromo-2-phenyl-3-methylbutane was accomplished according to a modified literature procedure. ${ }^{51}$ An oven-dried schlenk flask was charged with $10.54 \mathrm{~g} \mathrm{Ph}_{3} \mathrm{P}(40.2$ mmol), a stir bar, and $100 \mathrm{~mL}$ anhydrous dichloromethane and cooled on a schlenk line 
using a brine/ice bath. To the schlenk flask was added enough bromine $(2.1 \mathrm{~mL}, 40.2$ mmol) dropwise until a faint yellow color persisted, indicating full consumption of the $\mathrm{Ph}_{3} \mathrm{P}$. The flask was stirred for 5 minutes and $6.00 \mathrm{~g}(36.5 \mathrm{mmol})$ of 2-phenyl-3-methyl-1butanol was added dropwise over the course of 1 minute. The reaction was allowed to warm to room temperature and stirred for 2 hours. Following full conversion (as indicated by $T L C)$, the reaction was slowly quenched with dropwise addition of water. The reaction solution was diluted with $50 \mathrm{~mL}$ dichloromethane extracted with concentrated aqueous $\mathrm{NaHCO}_{3}$ solution $(2 \times 50 \mathrm{~mL})$. The organic layers were washed with $50 \mathrm{~mL}$ brine and dried over magnesium sulfate. Following solvent evaporation, the crude product was dissolved in hexane and filtered through a small plug of silica, eluting with hexane to remove the triphenylphosphine oxide byproduct. The filtrate was concentrated and the crude product was via column chromatography using hexane as the eluent to obtain $3.14 \mathrm{~g}\left(13.8 \mathrm{mmol}, 38 \%\right.$ yield) of 1-bromo-2-phenyl-3-methylbutane as a clear oil. ${ }^{1} \mathrm{H}$ NMR (500 MHz, $\left.\mathrm{CDCl}_{3}, 23 \stackrel{\circ}{\circ} \mathrm{C}\right): \delta 0.67\left(\mathrm{~d},{ }^{3} \mathrm{~J}_{\mathrm{HH}}=6.7 \mathrm{~Hz}, 3 \mathrm{H}\right.$, diastereotopic iso-propyl $\left.\mathrm{CH}_{3}\right), 0.99\left(\mathrm{~d},{ }^{3} \mathrm{JHH}_{\mathrm{H}}=6.7 \mathrm{~Hz}, 3 \mathrm{H}\right.$, diastereotopic iso-propyl $\left.\mathrm{CH}_{3}\right), 2.08(\mathrm{~m}$, iso-propyl $\mathrm{CH}$ ), $2.72\left(\mathrm{ddd},{ }^{3} \mathrm{JHH}_{\mathrm{HH}}=8.2 \mathrm{~Hz},{ }^{3} \mathrm{JHH}_{\mathrm{HH}}=8.2 \mathrm{~Hz},{ }^{3} \mathrm{~J}_{\mathrm{HH}}=4.9 \mathrm{~Hz}, 1 \mathrm{H}, \mathrm{PhCH}\right), 3.66\left(\mathrm{dd},{ }^{2} J_{\mathrm{HH}}=10.1\right.$ $\mathrm{Hz},{ }^{3} J_{H H}=8.7 \mathrm{~Hz}, 1 \mathrm{H}$, diastereotopic $\left.\mathrm{CH}_{2} \mathrm{Br}\right), 3.78\left(\mathrm{dd},{ }^{2} J_{\mathrm{HH}}=10.1 \mathrm{~Hz},{ }^{3} \mathrm{~J}_{\mathrm{HH}}=4.9 \mathrm{~Hz}, 1 \mathrm{H}\right.$, diastereotopic $\mathrm{CH}_{2} \mathrm{Br}$ ), 7.14-7.17 (m, 2H, o-phenyl $\mathrm{CH}$ ), 7.23-7.28 (m, $1 \mathrm{H}, p$-phenyl $\mathrm{CH}$ ), 7.30-7.34 (m, $2 \mathrm{H}, \mathrm{m}$-phenyl $\mathrm{CH}) .{ }^{1} \mathrm{H}$ and ${ }^{13} \mathrm{C}$ NMR spectra are consistent with previously reported data. ${ }^{52}$

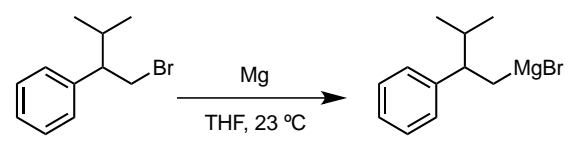

(3-methyl-2-phenylbutyl)magnesium bromide. An oven-dried thick walled glass vessel was charged with $2.00 \mathrm{~g}(82 \mathrm{mmol})$ magnesium ribbon and a stir bar and heated under vacuum using a heat gun. Upon cooling to room temperature, the flask was 
charged with $20 \mathrm{~mL}$ anhydrous tetrahydrofuran. To the flask was added $1.528 \mathrm{~g}(6.73$ mmol) 1-bromo-2-phenyl-3-methylbutane dropwise. The flask was sonicated at room temperature for 2 hours and stirred at room temperature for an additional 2 hours. The reaction vessel was transferred to nitrogen-filled glove box and the reaction was filtered through celite to remove unreacted magnesium metal. The Grignard reagent solution in THF was stored in a nitrogen atmosphere at $-35^{\circ} \mathrm{C}$. The concentration of the Grignard reagent was determined to be $0.116 \mathrm{M}$ according to a literature procedure. ${ }^{53}$

Racemic 1-bromo-2-phenyl-3-methylbutane was separated into its two enantiomers by Lotus Separations using preparatory chiral SFC separation $(\mathrm{OJ}-\mathrm{H}, 40 \%$ IPA (DEA)/CO 2,100 bar, $3.0 \mathrm{~mL} / \mathrm{mol}, 220 \mathrm{~nm}$, enantiomer 1: $1.51 \mathrm{~min}$, enantiomer 2: $1.69 \mathrm{~min})$. The same Grignard formation procedure was used for the enantioriched alkyl bromide reagents. The absolute configuration of the alkyl Grignard reagent was determined by hydrolyzing a sample of the Grignard reagent and analyzing the resulting alkane by chiral GC according to literature procedures. ${ }^{2}$ The ee values reported in Scheme 5 correspond to the resulting alkanes from the hydrolysis of the alkylmagnesium bromide.

\section{B. Treatment of (S)-CoCl with Grignard reagents.}

To a J. Young NMR tube was added $0.007 \mathrm{~g}(0.013 \mathrm{mmol})(\mathrm{S})-\mathrm{CoCl}$ and $0.4 \mathrm{~mL} \mathrm{C}_{6} \mathrm{D}_{6}$. To the tube was added $0.115 \mathrm{~mL}$ of rac-(3-methyl-2-phenylbutyl)magnesium bromide at room temperature. A ${ }^{1} \mathrm{H}-\mathrm{NMR}$ spectrum was acquired to determine the formation of (S)$\mathrm{CoH},(\mathrm{S})-\mathrm{Co}-\mathrm{CM}$, alkene 21, and alkane 22. The organics were analyzed by chiral GC to determine the ratio of products and the ee of the alkane. This same procedure was used with the enantioenriched alkylmagnesium bromide reagents. 


\section{Representative NMR Spectra.}
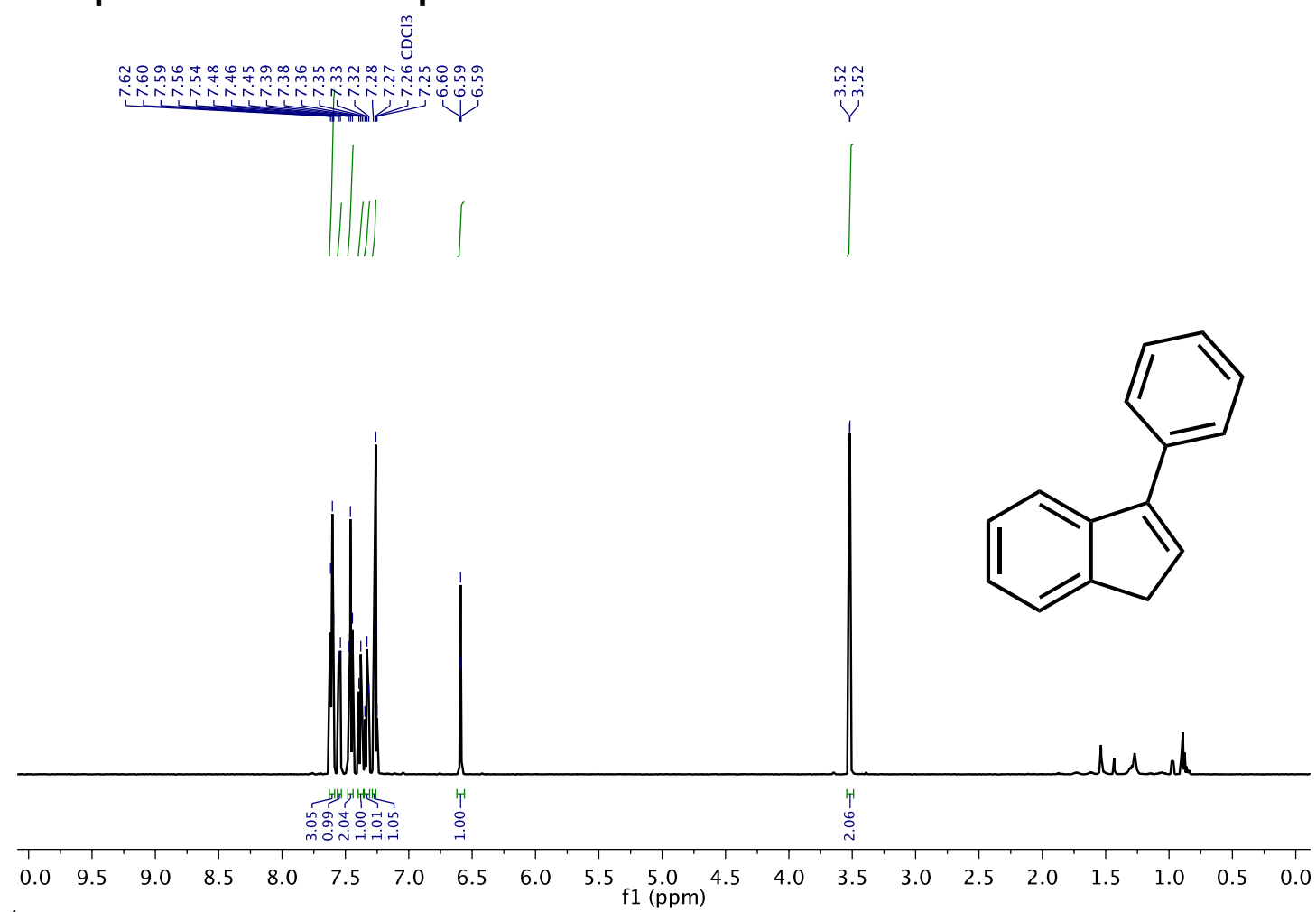

${ }^{1} \mathrm{H}$ NMR spectrum of 3-phenyl-1 $\mathrm{H}$-indene (1a).

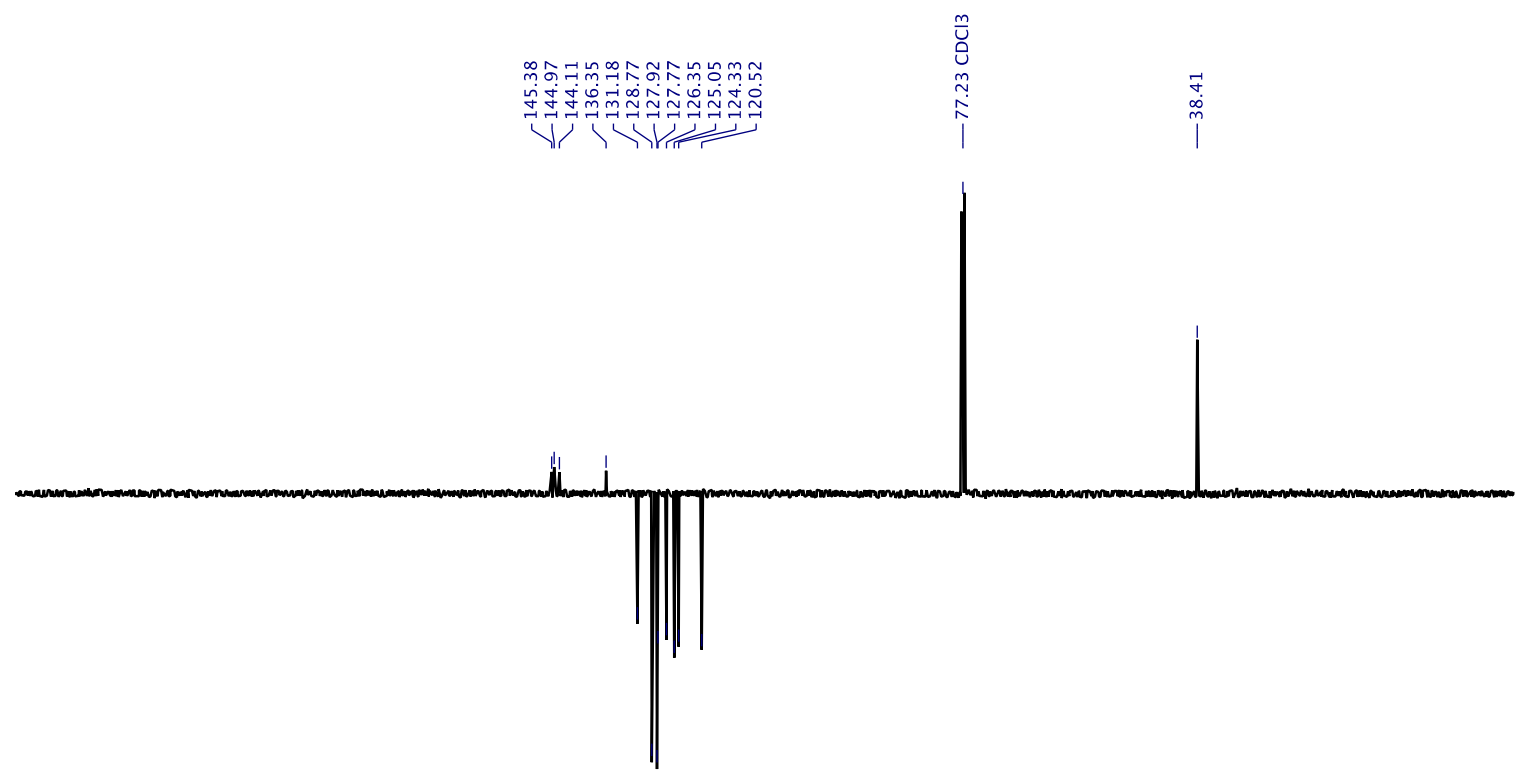

$\begin{array}{lllllllllllllllllllllllll}230 & 220 & 210 & 200 & 190 & 180 & 170 & 160 & 150 & 140 & 130 & 120 & 110 & 100 & 90 & 80 & 70 & 60 & 50 & 40 & 30 & 20 & 10 & 0 & -10\end{array}$ ${ }^{13} \mathrm{C}$ NMR APT spectrum of 3-phenyl-1 $\mathrm{H}$-indene (1a). 


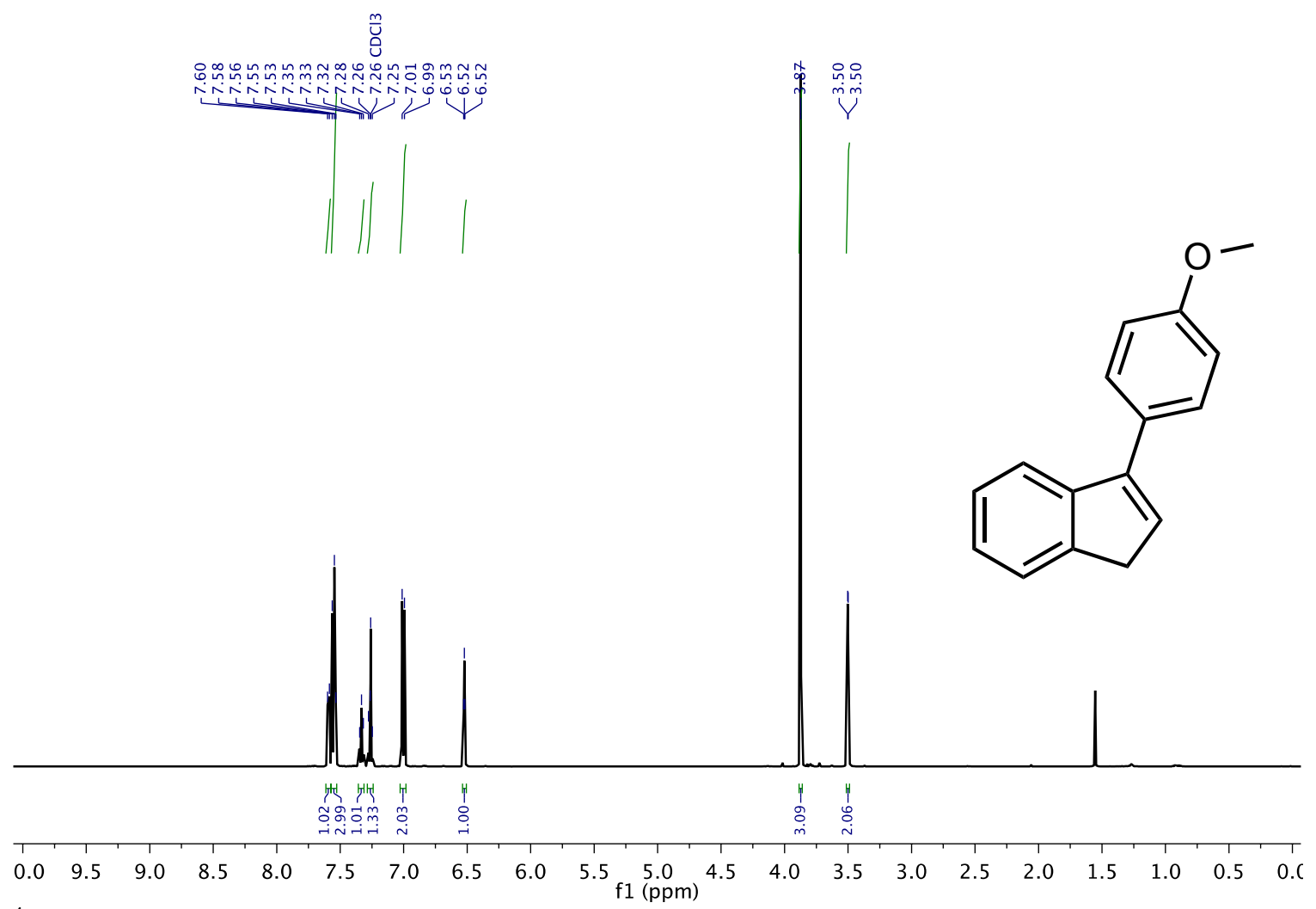

${ }^{1} \mathrm{H}$ NMR spectrum of 3-(p-methoxyphenyl)- $1 \mathrm{H}$-indene (1b).
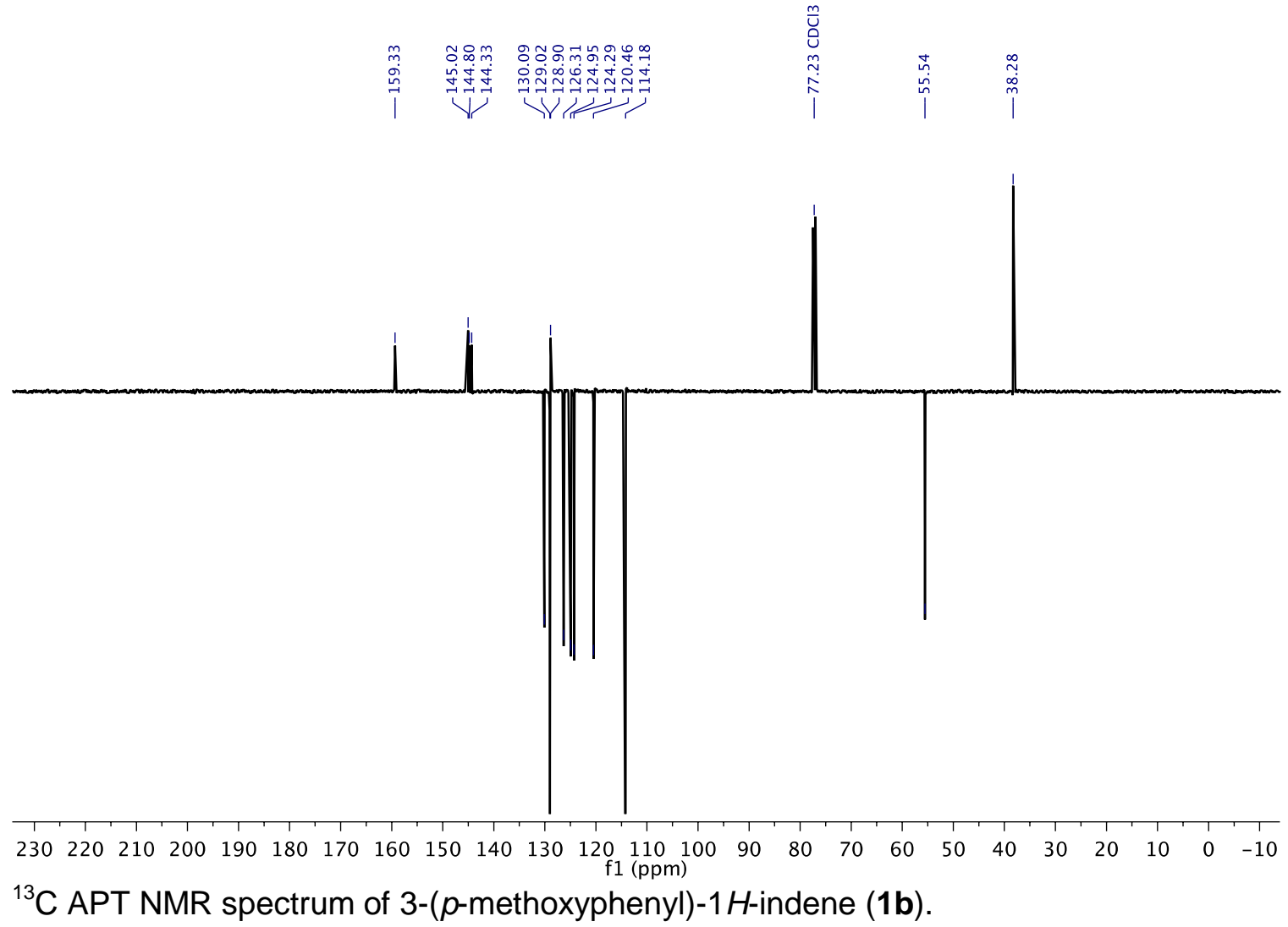


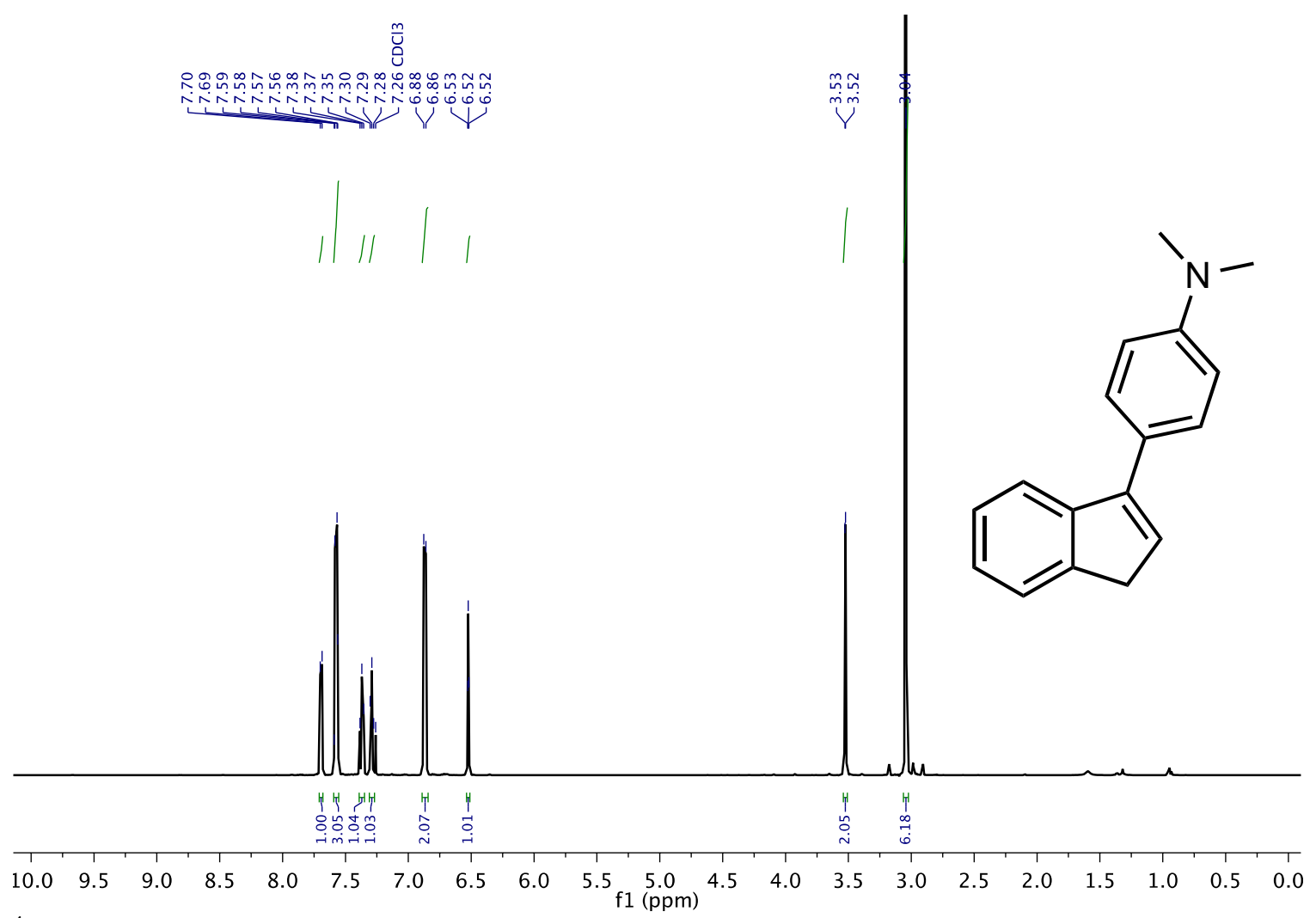

${ }^{1} \mathrm{H}$ NMR spectrum of 3 -(p-dimethylaminophenyl)-1 $\mathrm{H}$-indene (1c).

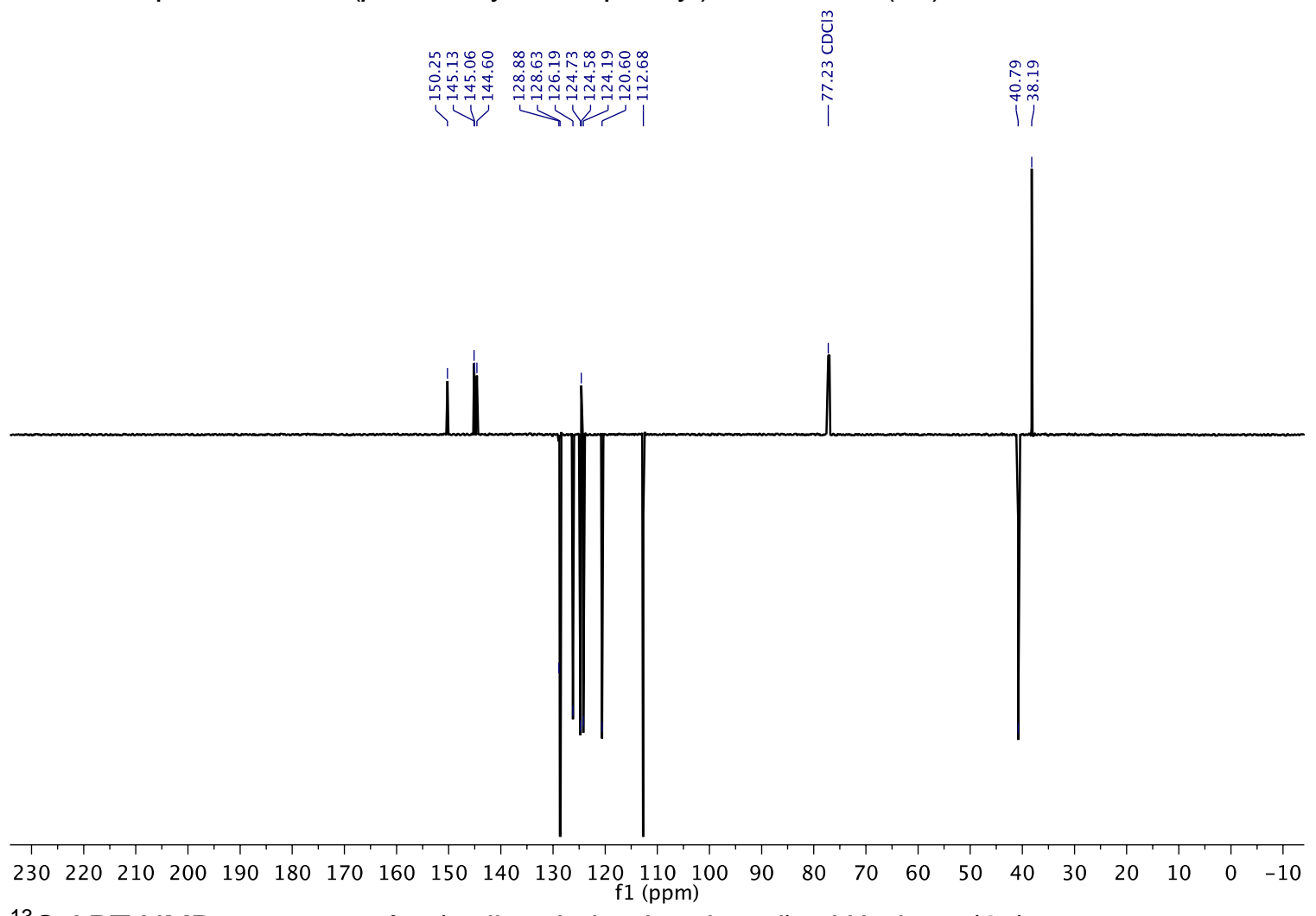

${ }^{13} \mathrm{C}$ APT NMR spectrum of 3 -(p-dimethylaminophenyl)-1 $H$-indene (1c). 


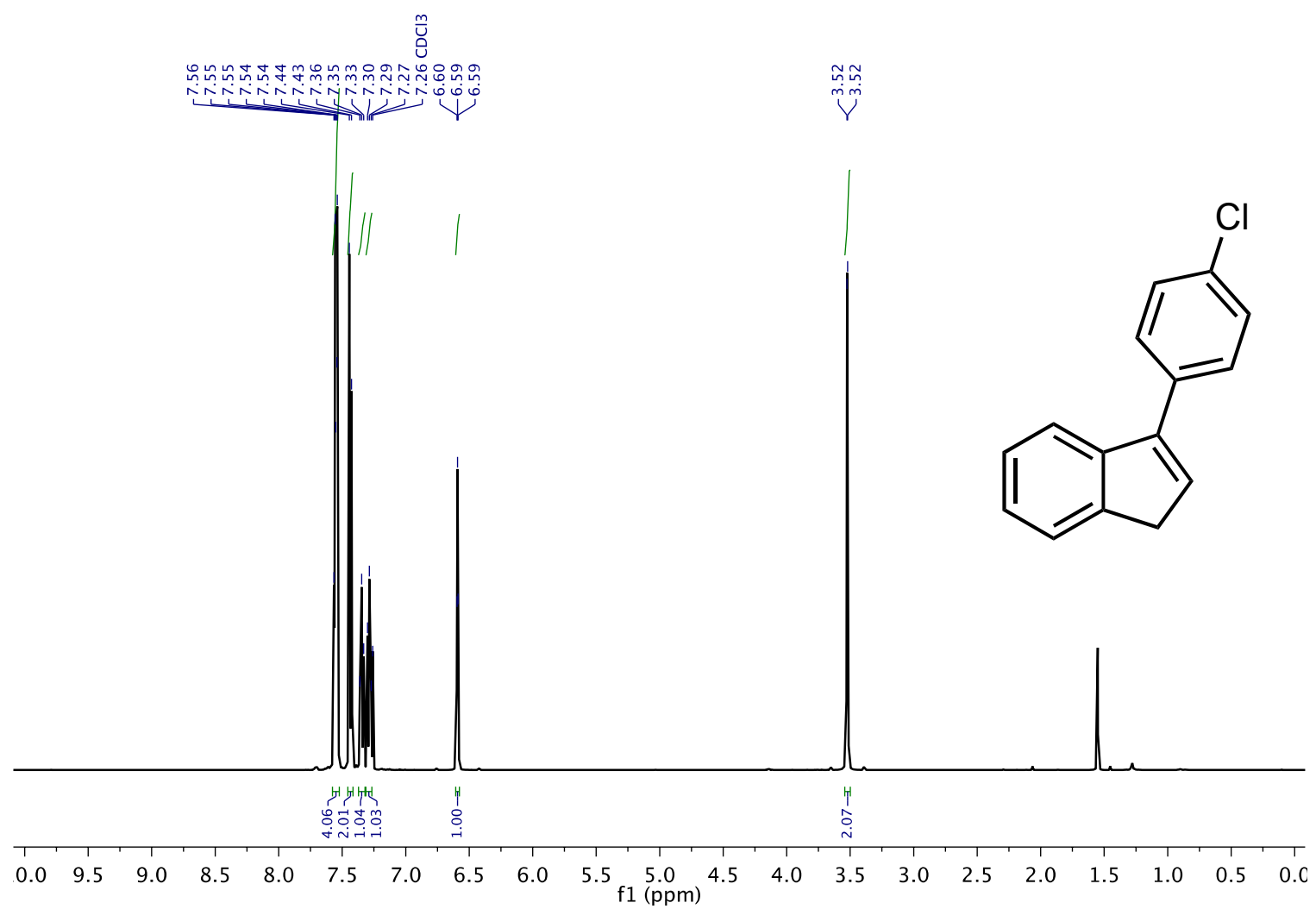

${ }^{1} \mathrm{H}$ NMR spectrum of 3 -( $p$-chlorophenyl)- $1 \mathrm{H}$-indene (1d).

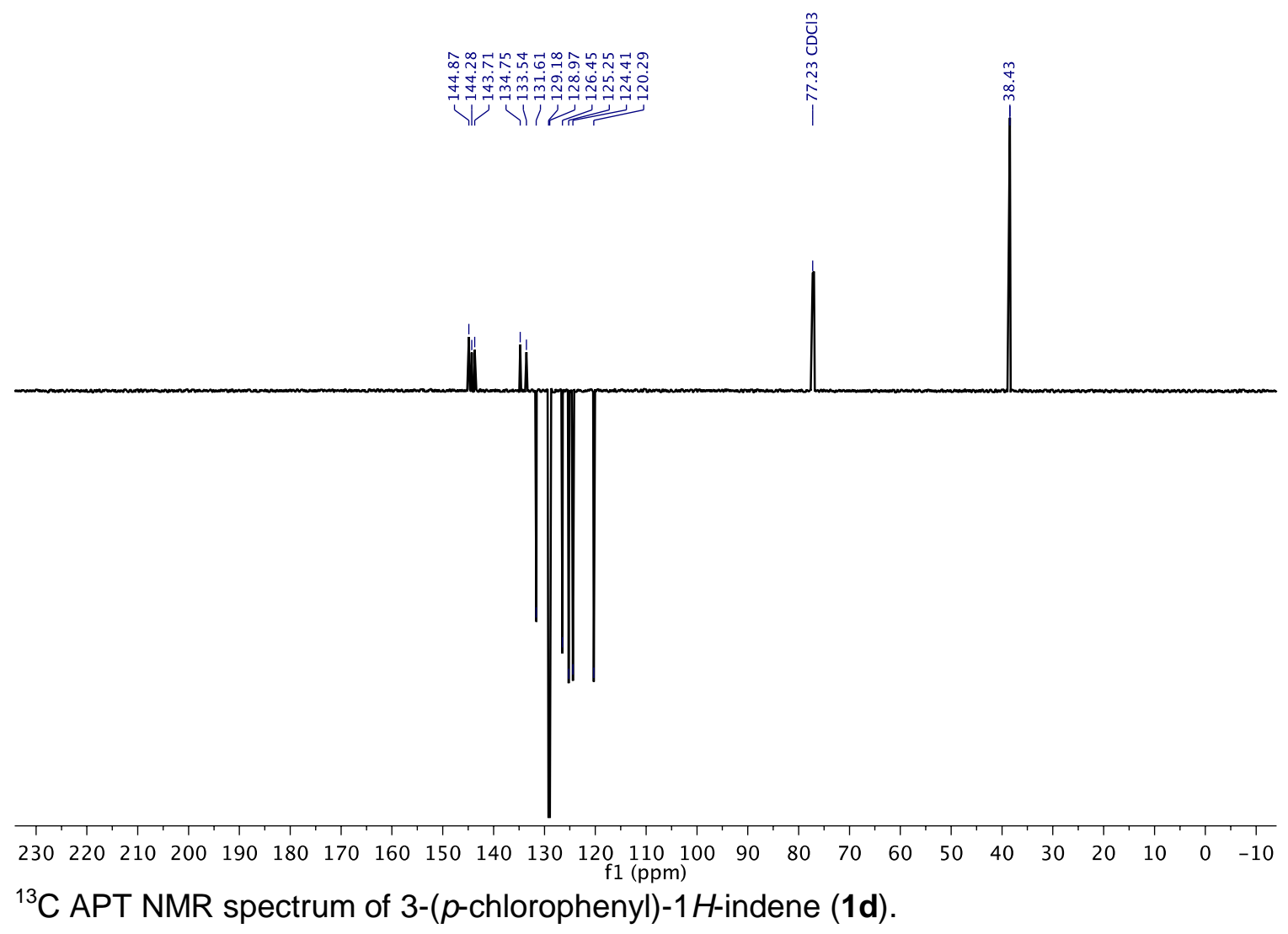




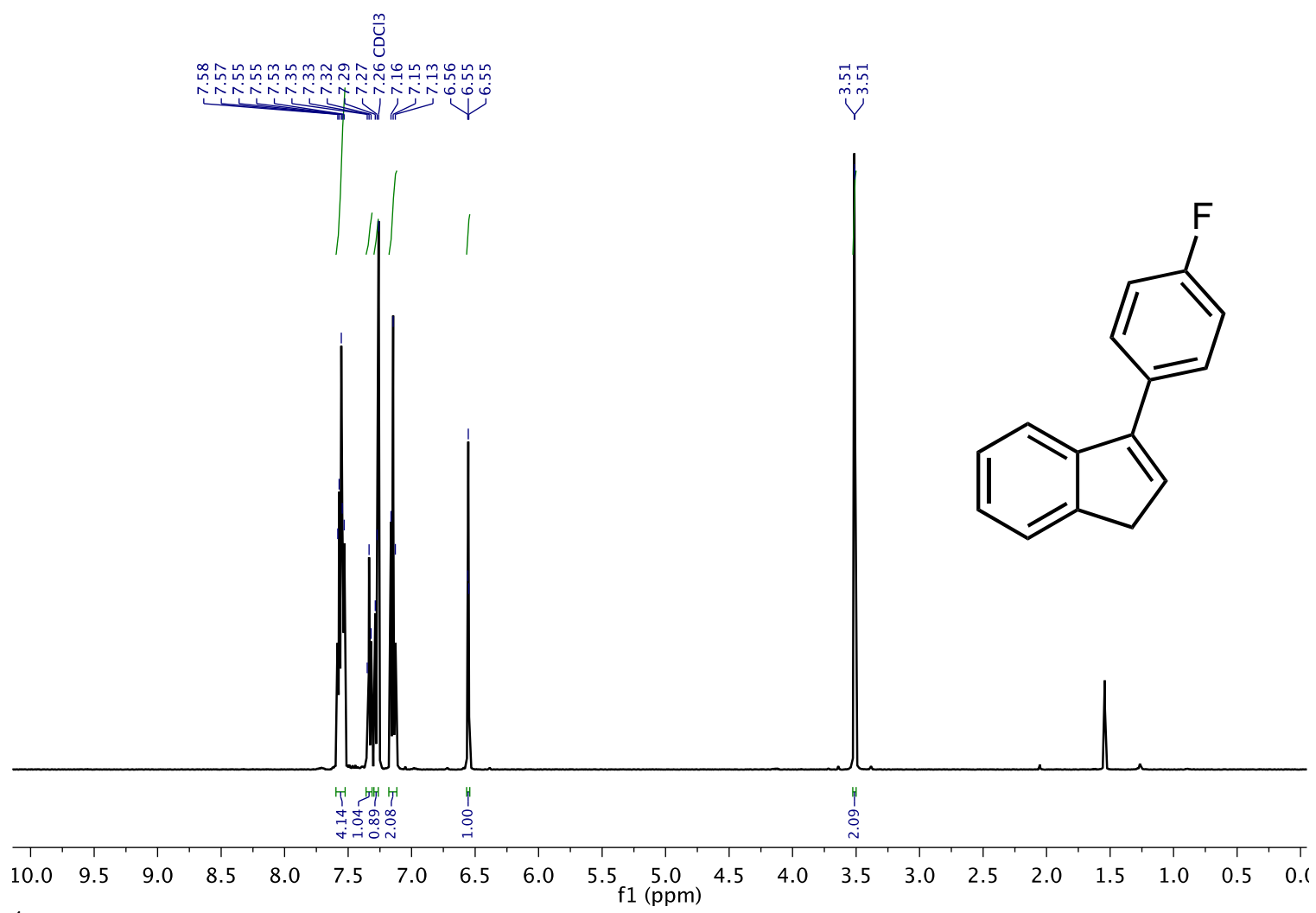

${ }^{1} \mathrm{H}$ NMR spectrum of 3-(p-fluorophenyl)- $1 \mathrm{H}$-indene (1e).

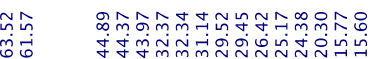

(1)
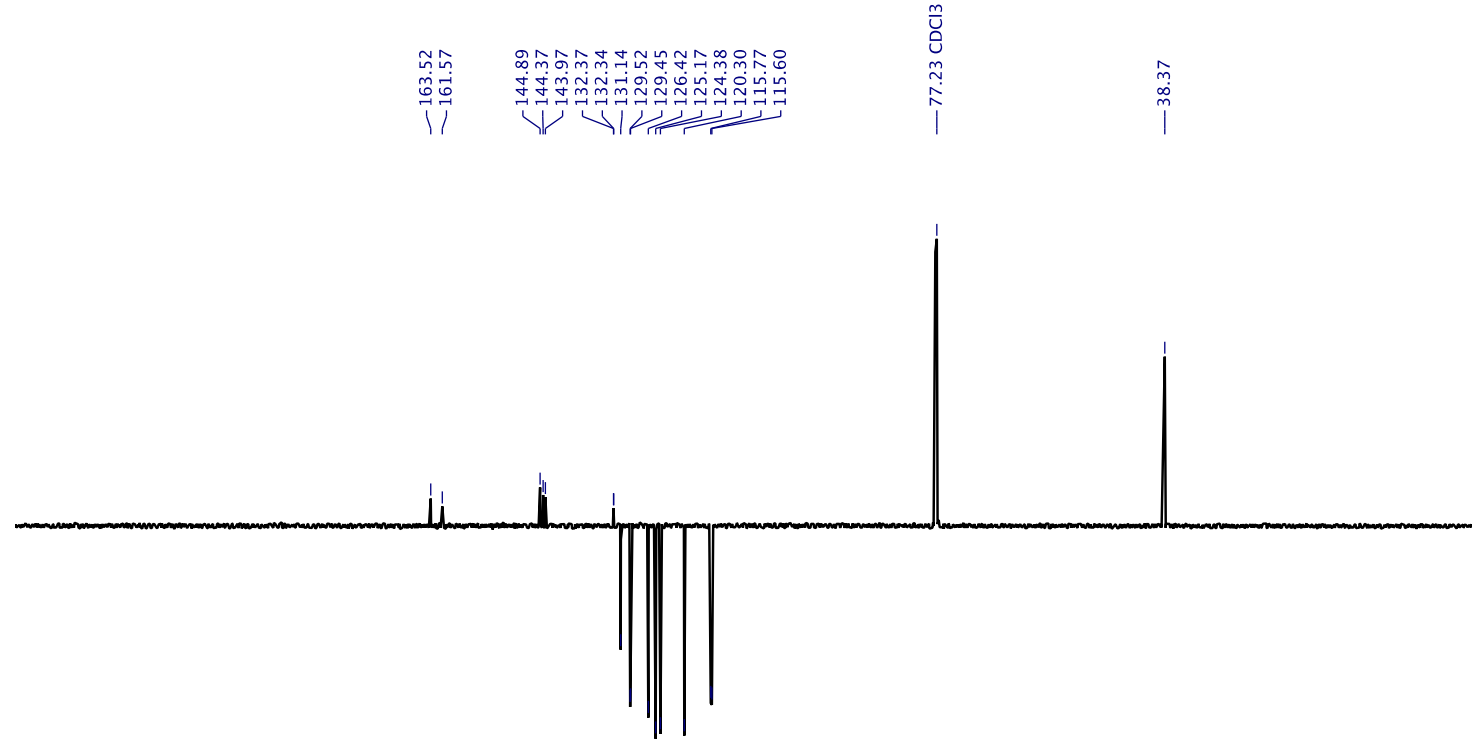

$\begin{array}{lllllllllllllllllllllllllllll}230 & 220 & 210 & 200 & 190 & 180 & 170 & 160 & 150 & 140 & 130 & 120 \\ \mathrm{f} 1 & 110(\mathrm{ppm}) & 100 & 90 & 80 & 70 & 60 & 50 & 40 & 30 & 20 & 10 & 0 & -10\end{array}$

${ }^{13} \mathrm{C}$ APT NMR spectrum of 3-(p-fluorophenyl)-1H-indene (1e). 


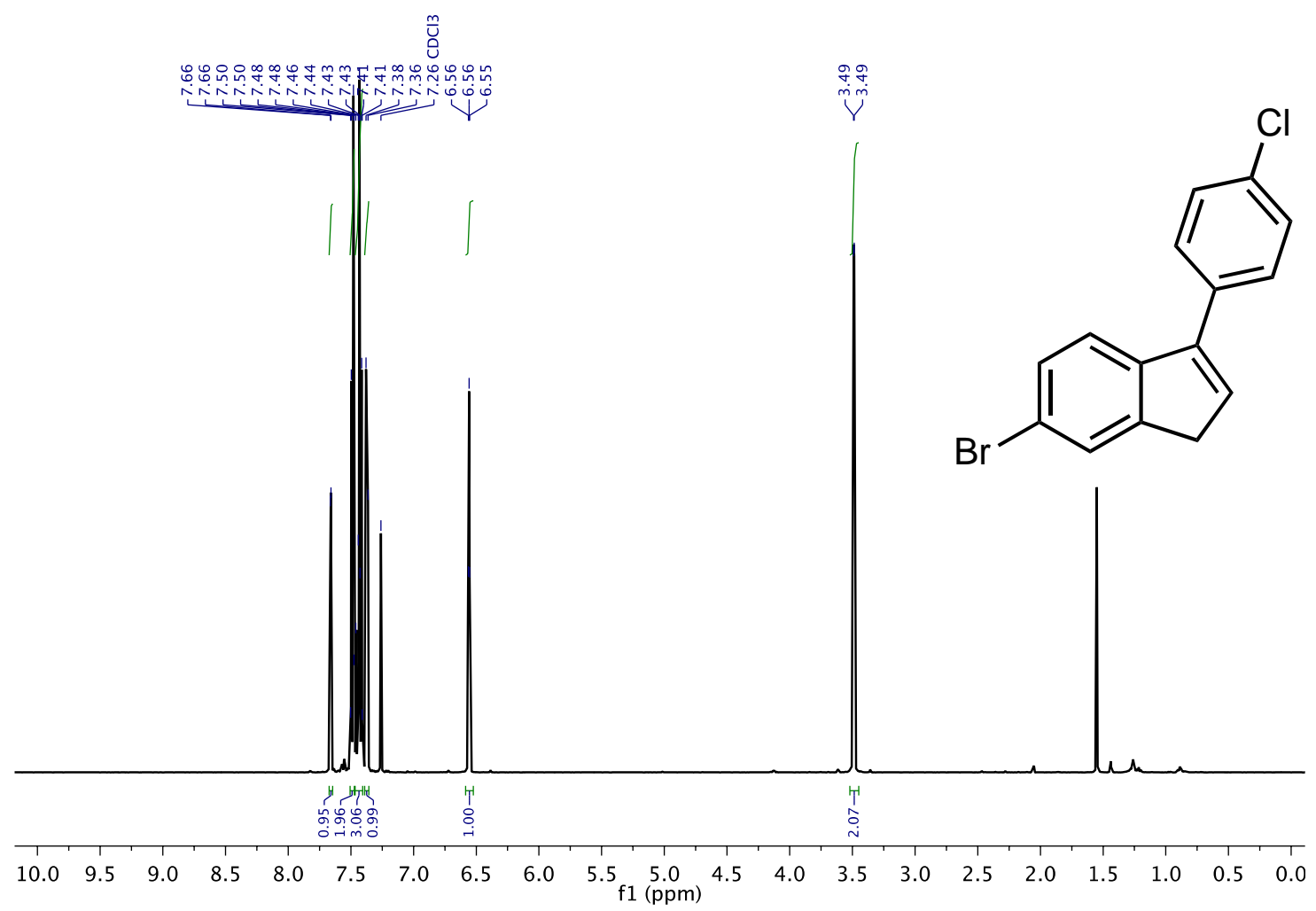

${ }^{1} \mathrm{H}$ NMR spectrum of 3-( $p$-chlorophenyl)-6-bromo-1H-indene (1f).

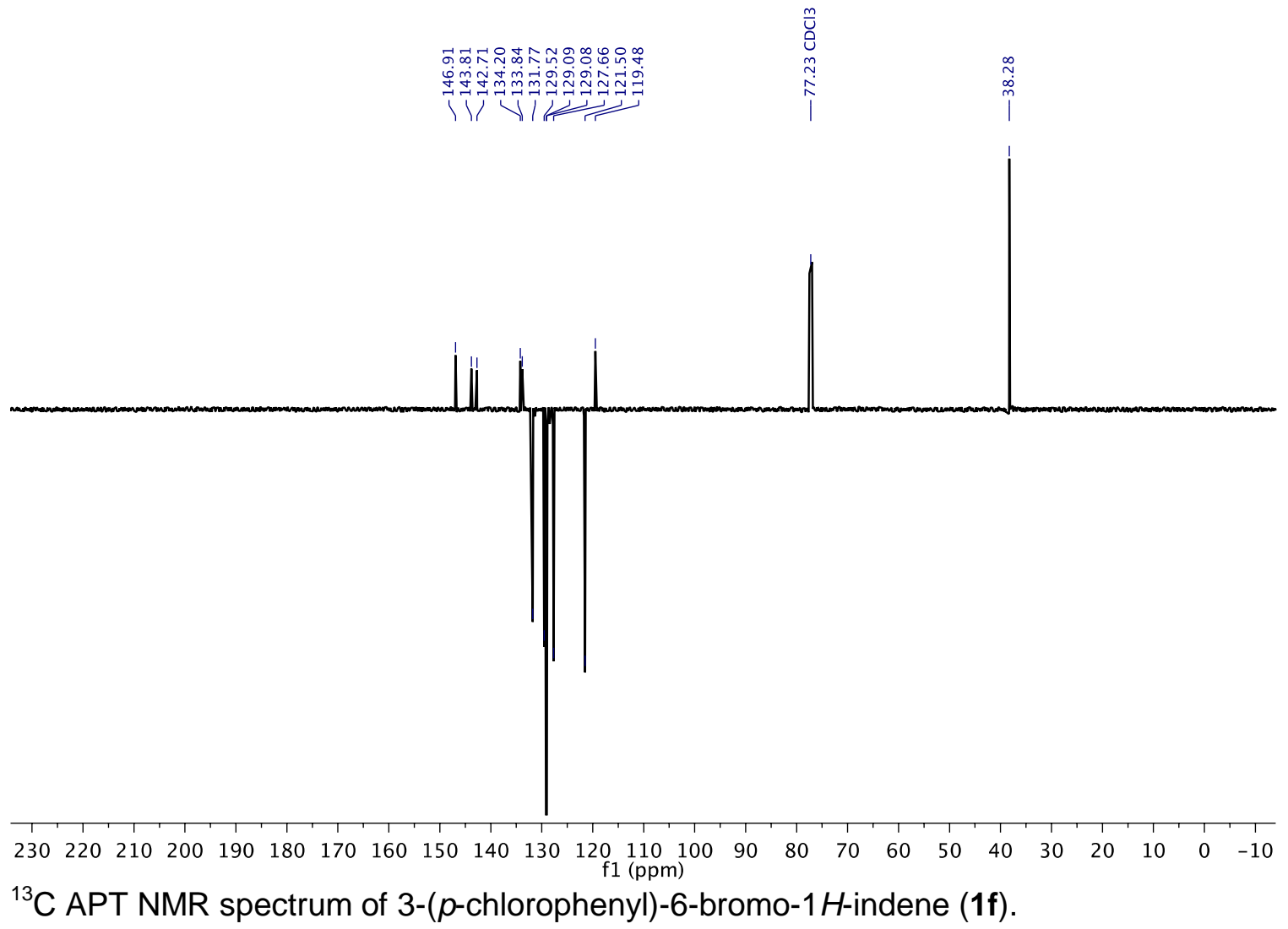




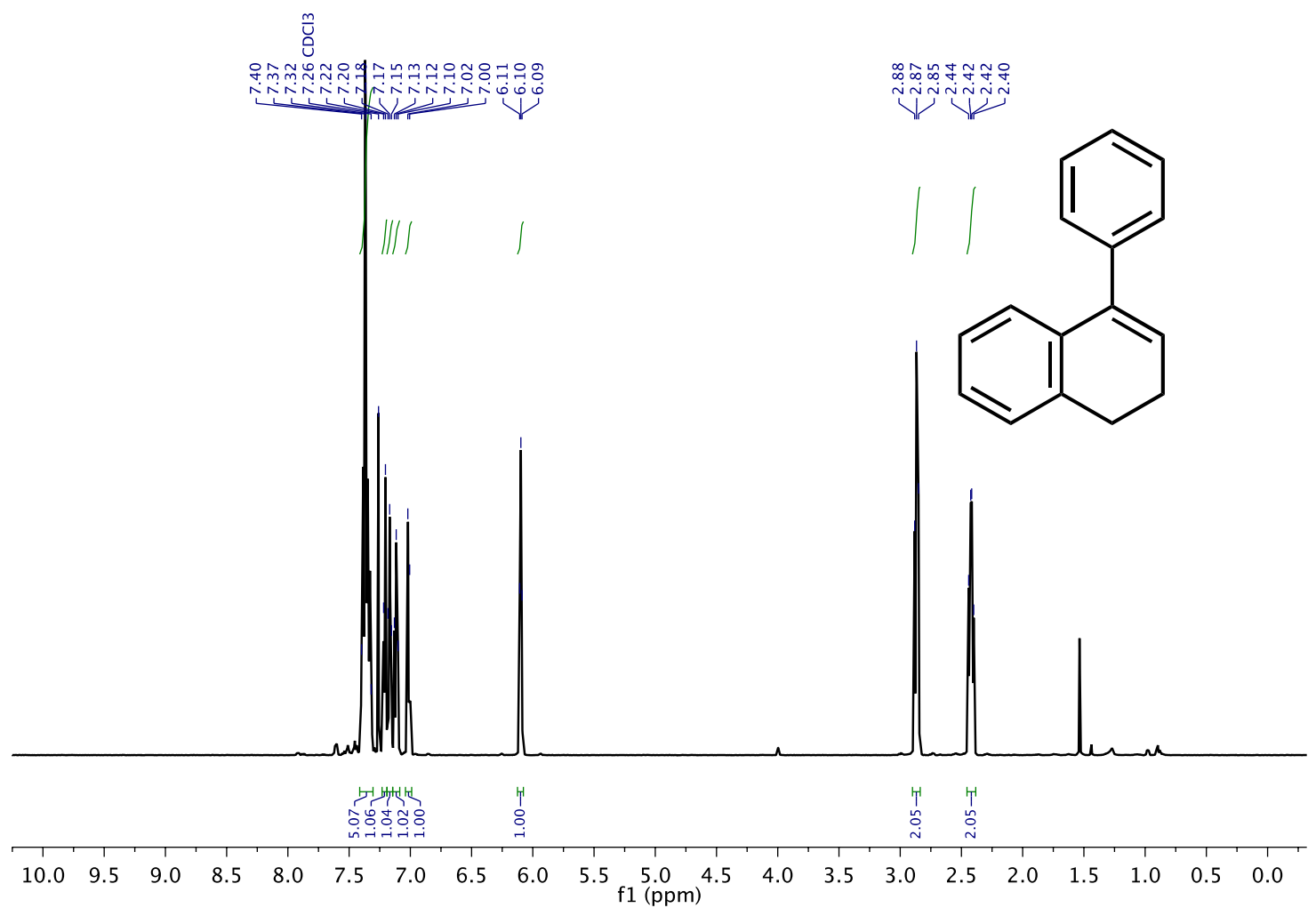

${ }^{1} \mathrm{H}$ NMR spectrum of 1-phenyl-3,4-dihydronaphthalene (3a).

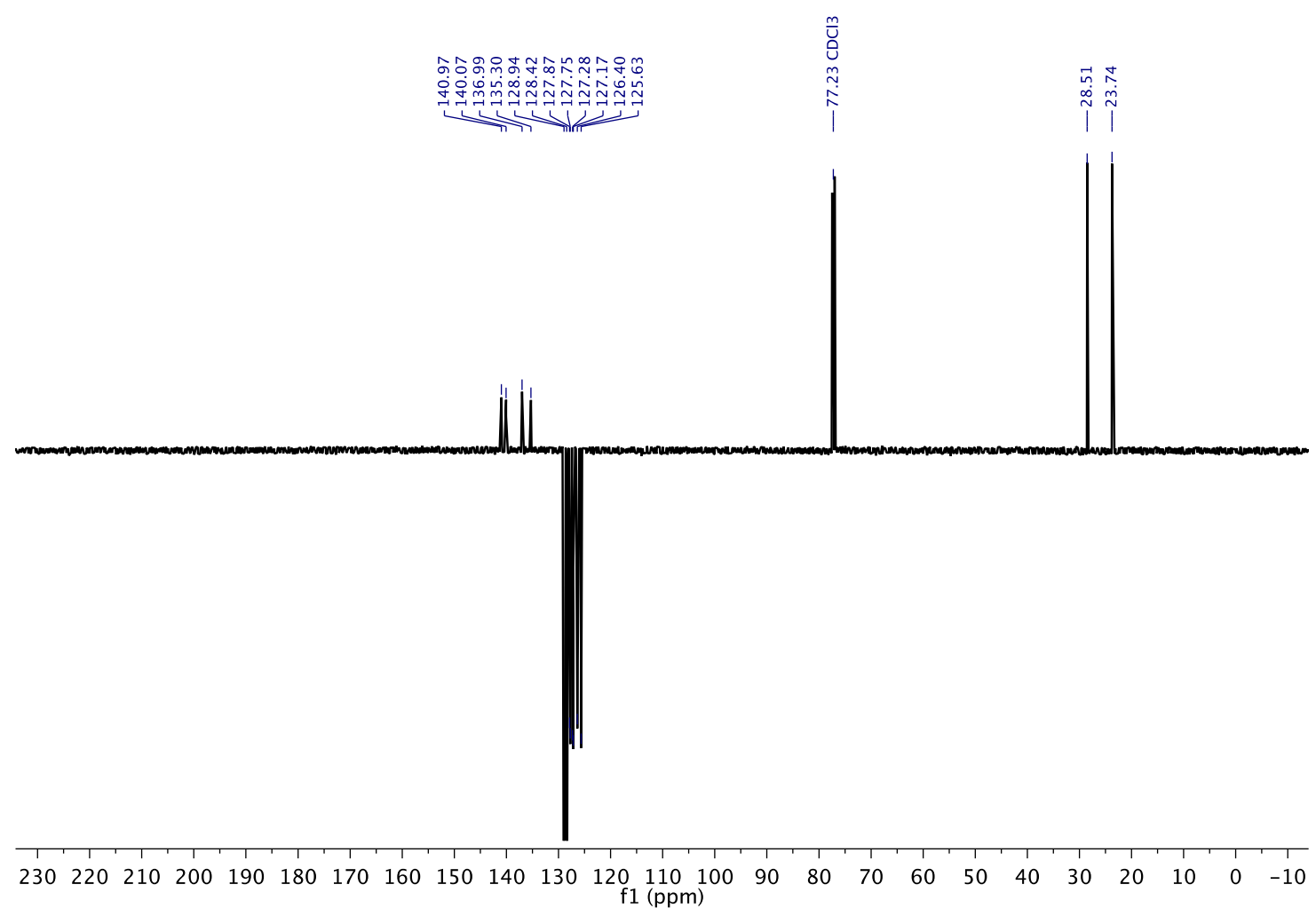

${ }^{13} \mathrm{C}$ APT NMR spectrum of 1-phenyl-3,4-dihydronaphthalene (3a). 


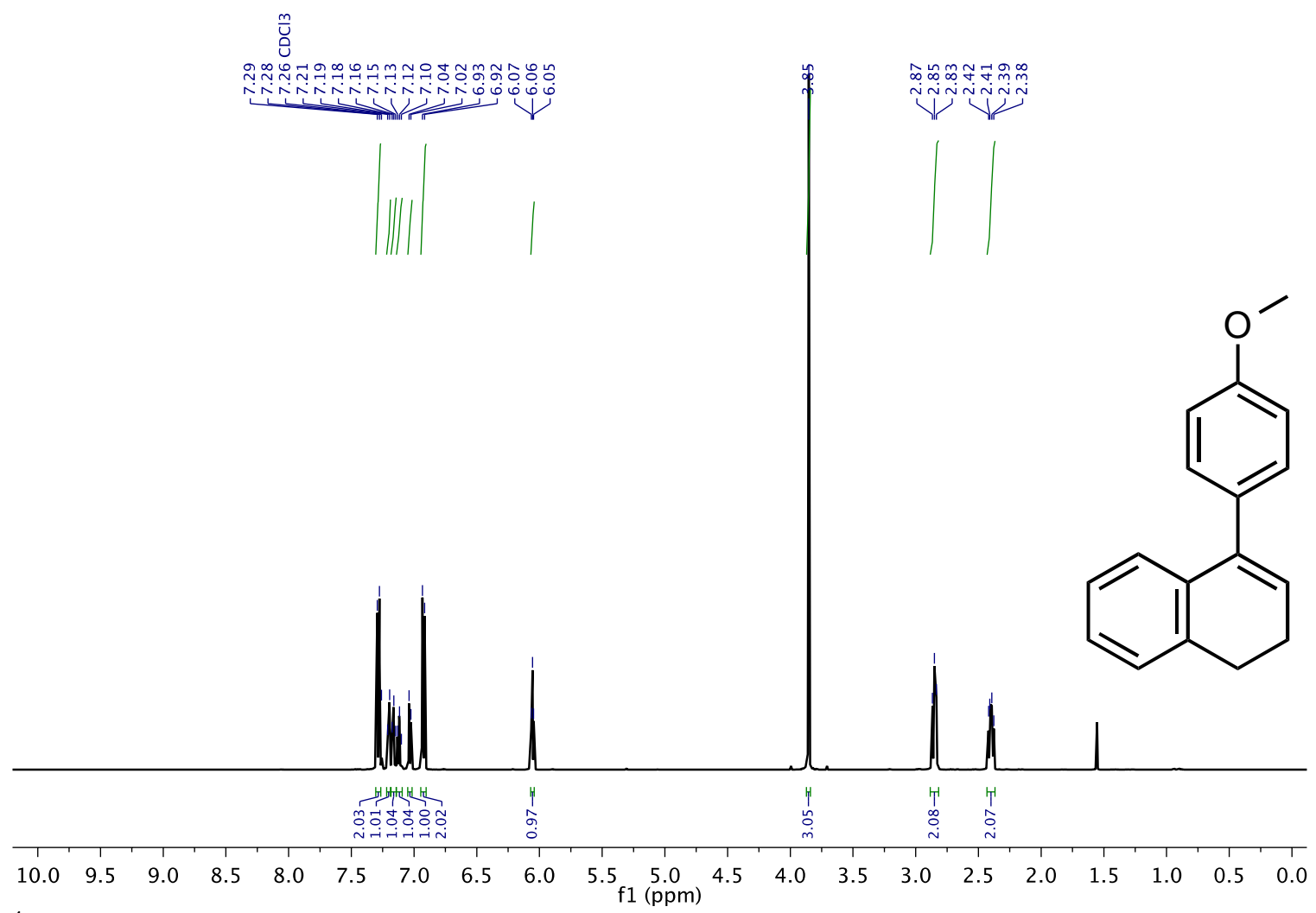

${ }^{1} \mathrm{H}$ NMR spectrum of 1-(p-methoxyphenyl)-3,4-dihydronaphthalene (3b).
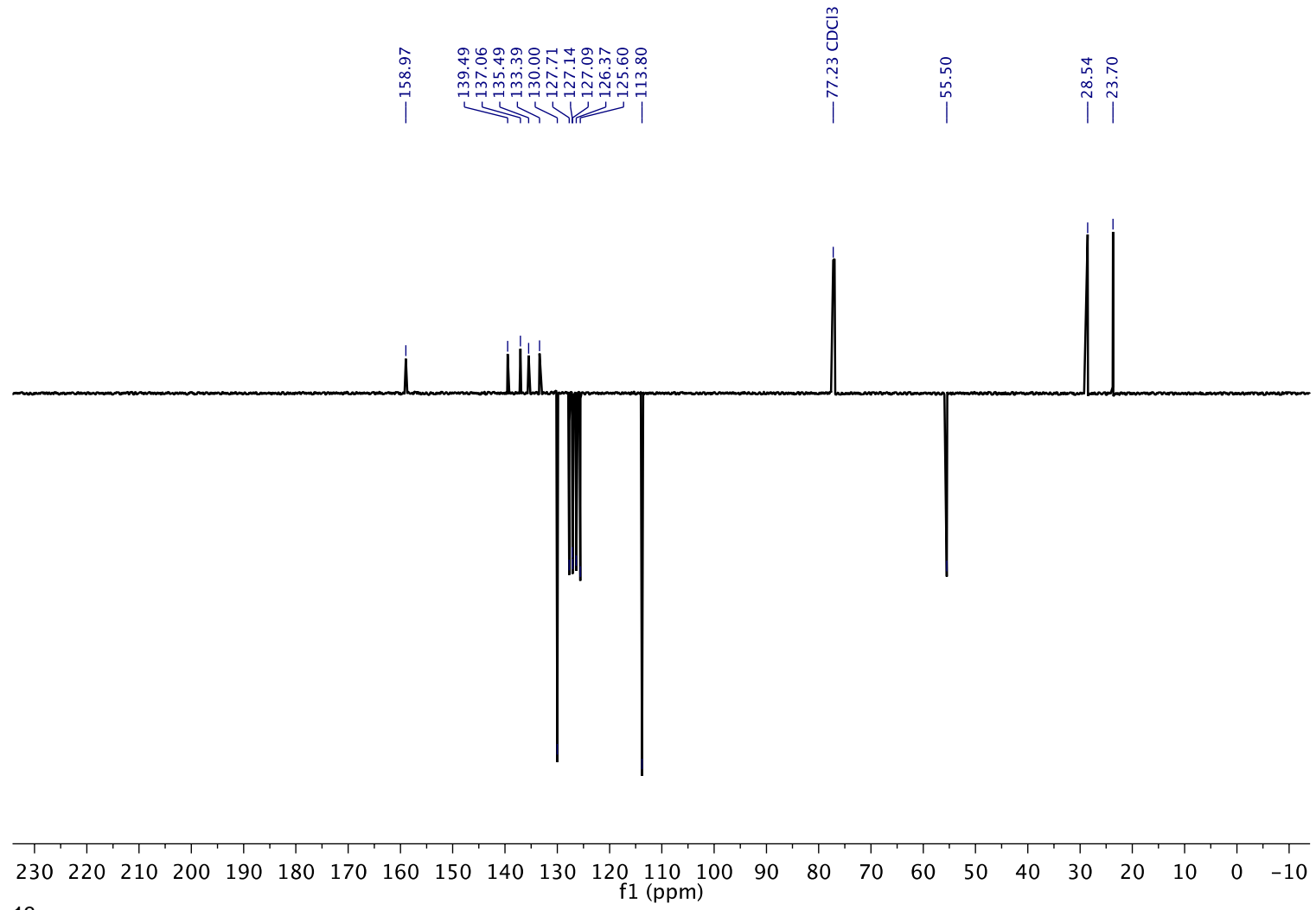

${ }^{13} \mathrm{C}$ APT NMR spectrum of 1-(p-methoxyphenyl)-3,4-dihydronaphthalene (3b). 


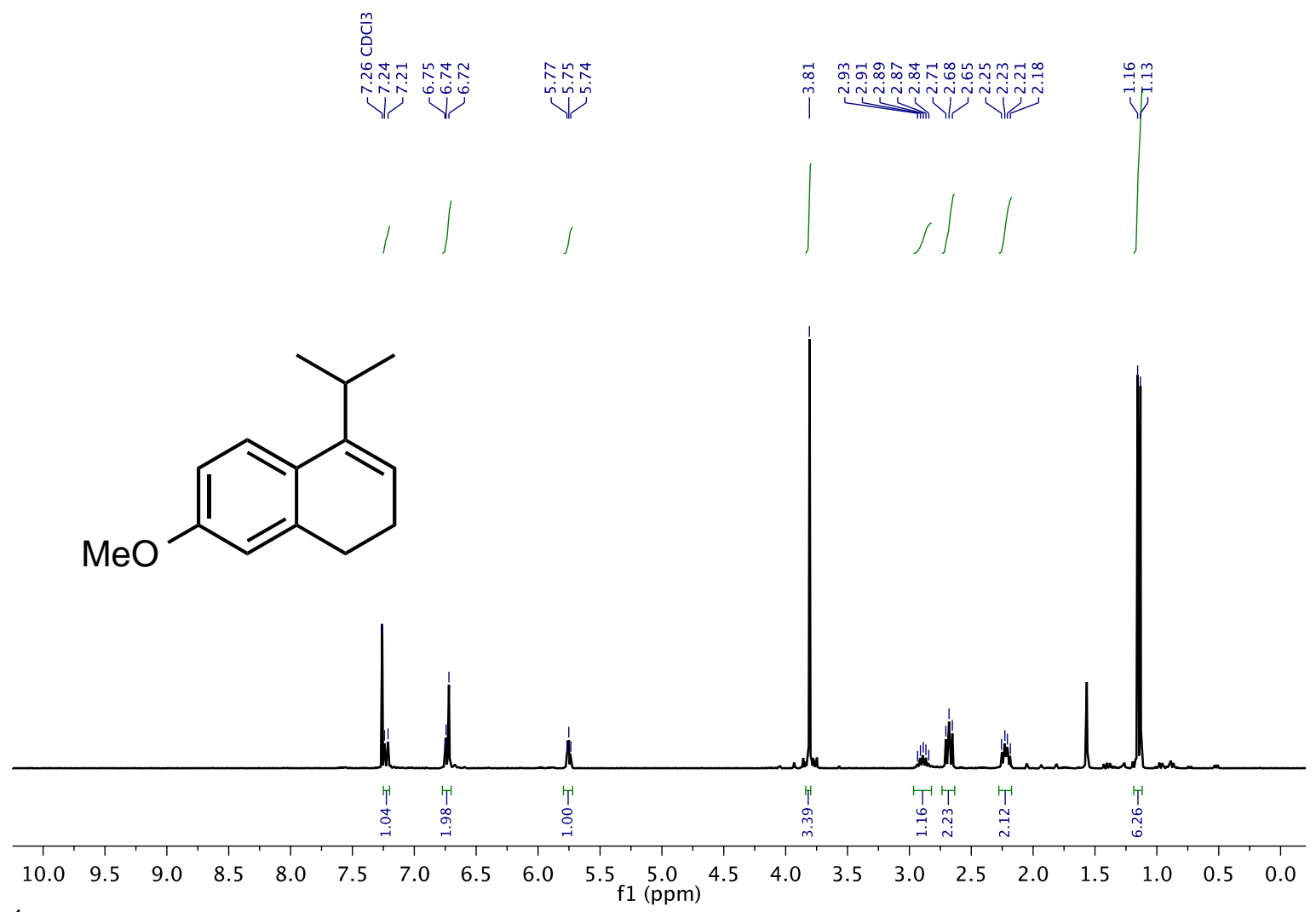

${ }^{1} \mathrm{H}$ NMR spectrum of 1-IPr-6-methoxy-3,4-dihydronaphthalene (5a).
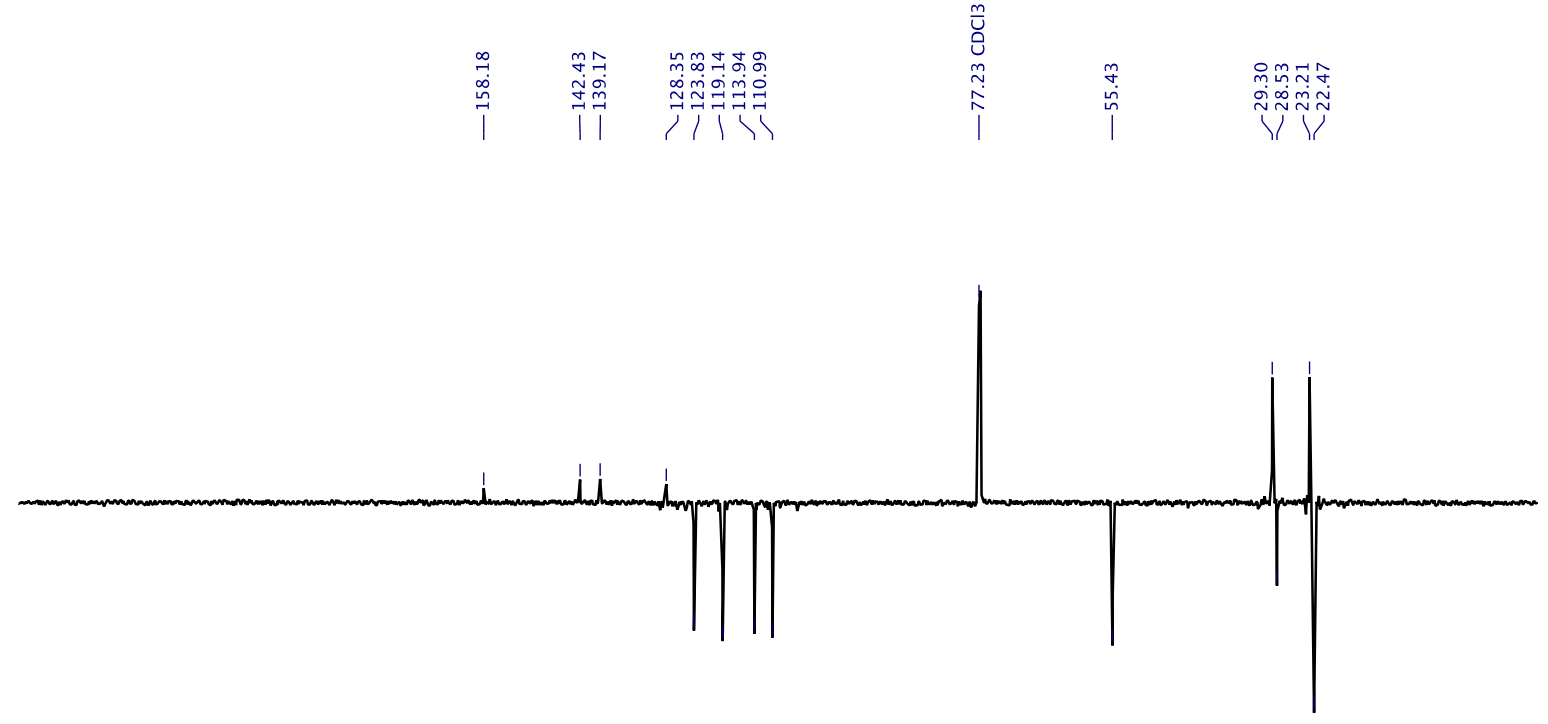

\begin{tabular}{llllllllllllllllllllllllllllll}
\hline 230 & 220 & 210 & 200 & 190 & 180 & 170 & 160 & 150 & 140 & 130 & 120 & 110 & 100 & 90 & 80 & 70 & 60 & 50 & 40 & 30 & 20 & 10 & 0 & -10
\end{tabular} ${ }^{13} \mathrm{C}$ APT NMR spectrum of 1 -iPr-6-methoxy-3,4-dihydronaphthalene (5a). 


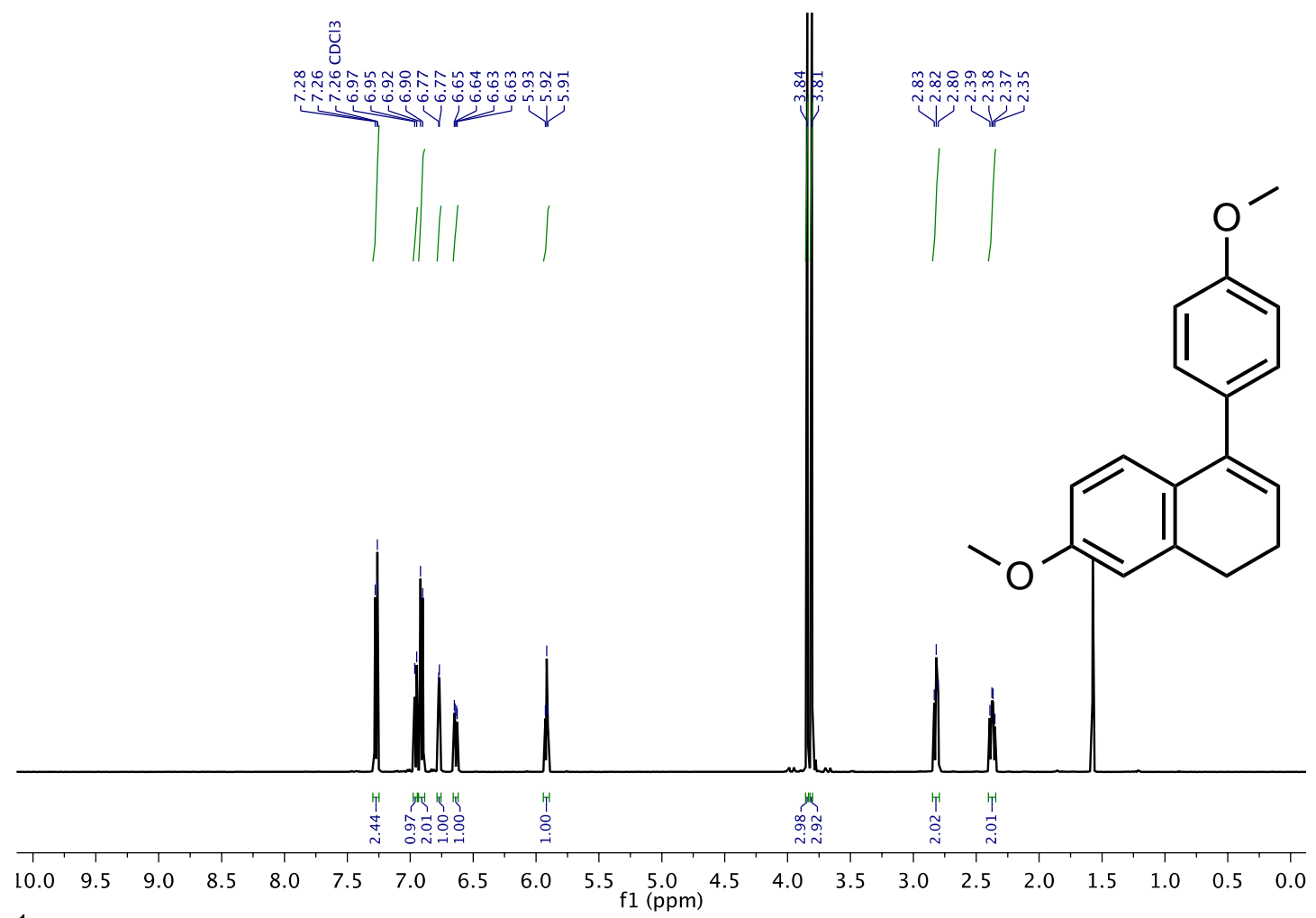

${ }^{1} \mathrm{H}$ NMR spectrum of 1-(p-methoxyphenyl)-6-methoxy-3,4-dihydronaphthalene (5b).

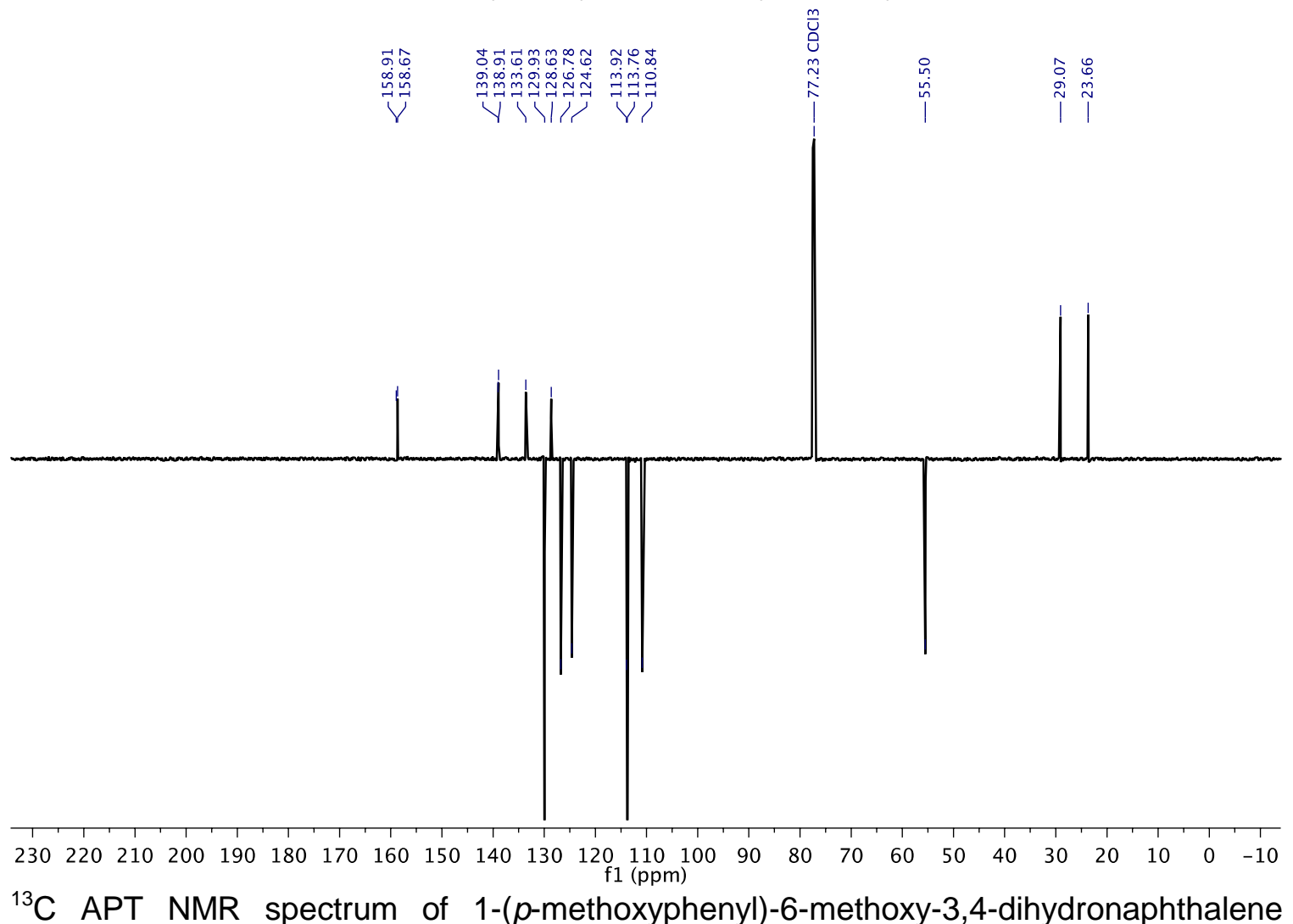
(5b). 

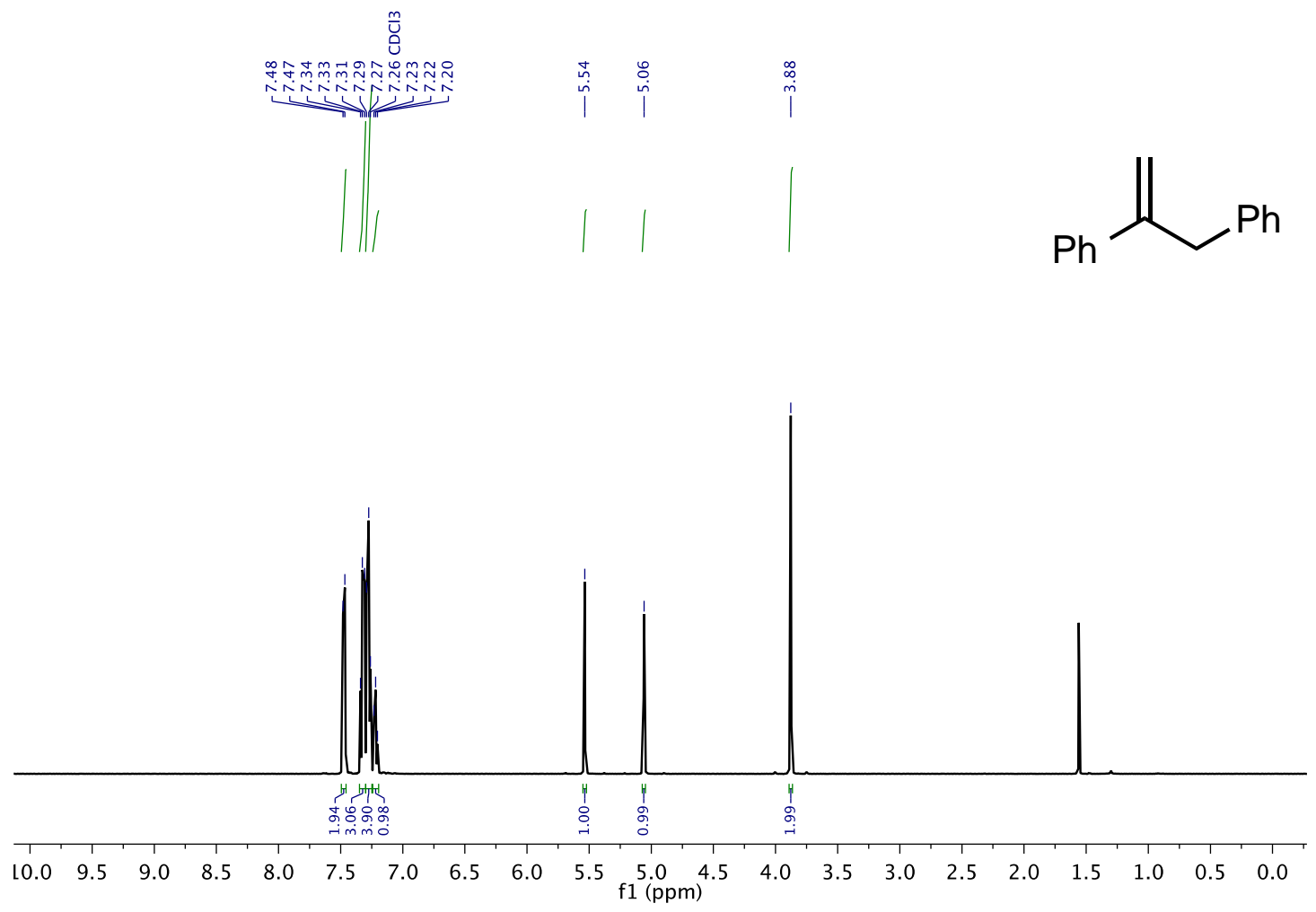

${ }^{1} \mathrm{H}$ NMR spectrum of 2,3-diphenylpropene (7a).
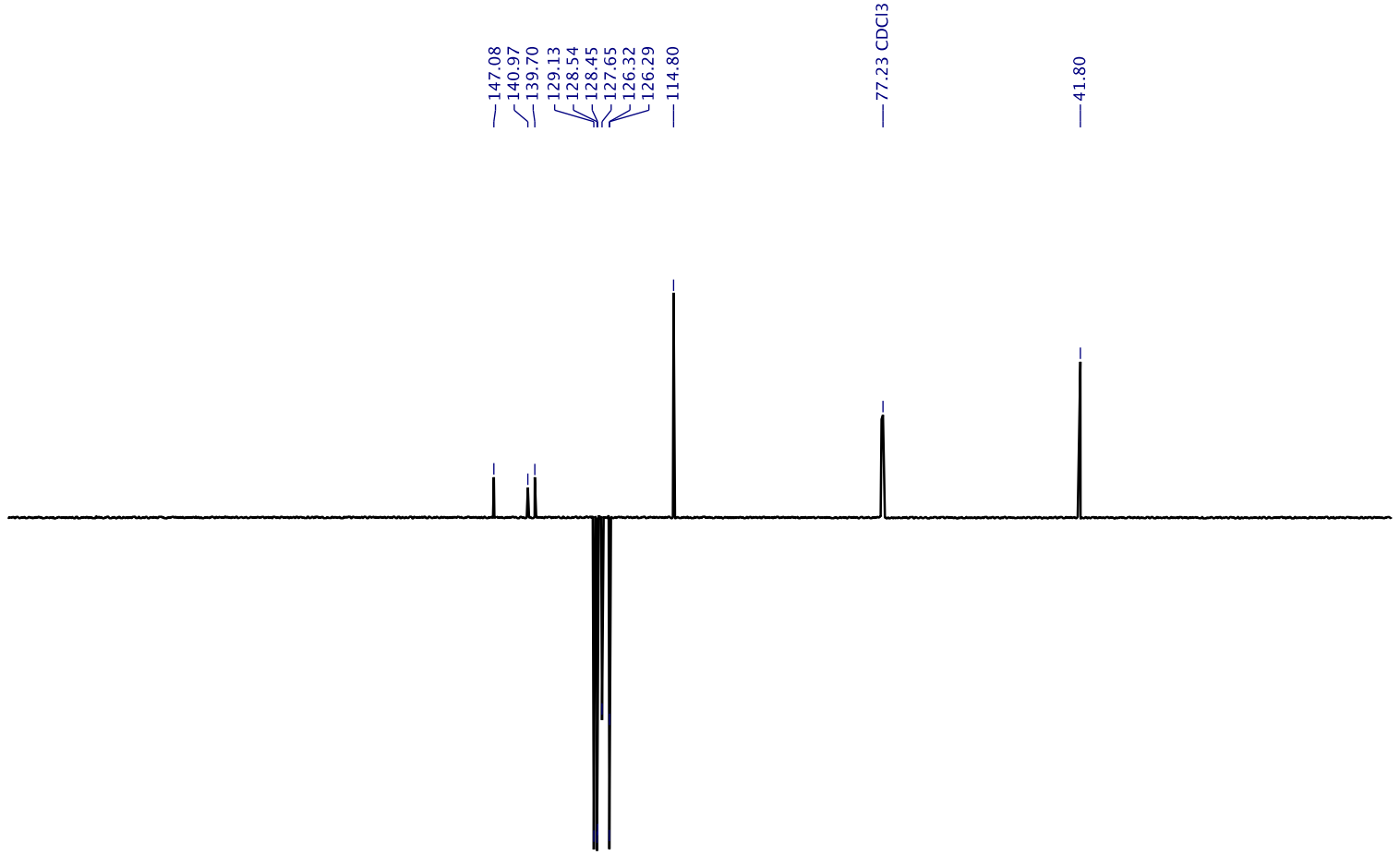

\footnotetext{
$\begin{array}{rllllllllllllllllllllllllll}230 & 220 & 210 & 200 & 190 & 180 & 170 & 160 & 150 & 140 & 130 & 120 & 110 & 100 & 90 & 80 & 70 & 60 & 50 & 40 & 30 & 20 & 10 & 0 & -10\end{array}$ ${ }^{13} \mathrm{C}$ APT NMR spectrum of 2,3-diphenylpropene (7a).
} 


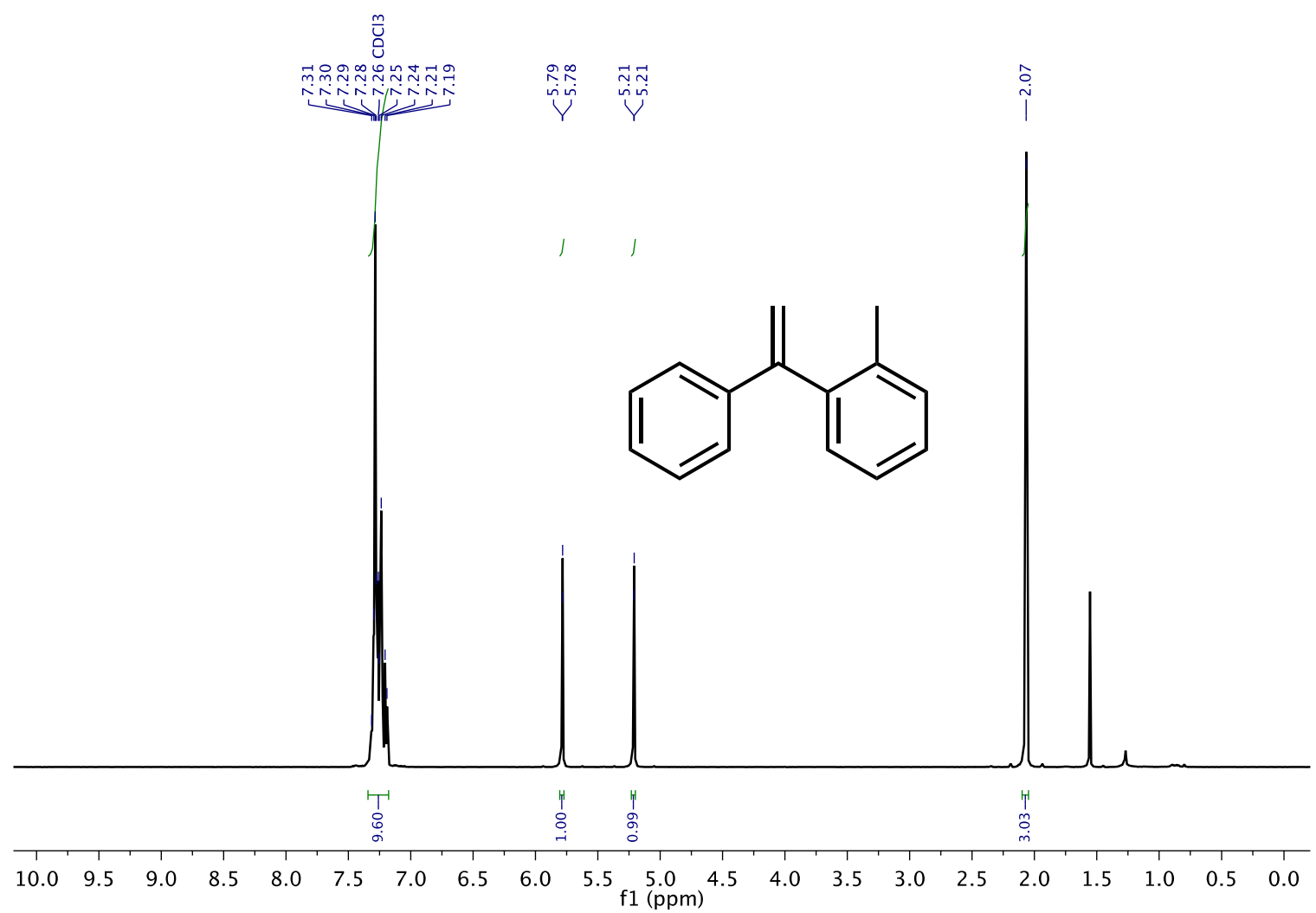

${ }^{1} \mathrm{H}$ NMR spectrum of 1-(o-tolyl)-1-phenyl-ethylene (9a).

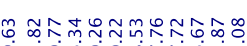

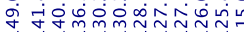

|र

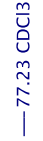

$\stackrel{m}{\stackrel{m}{i}}$

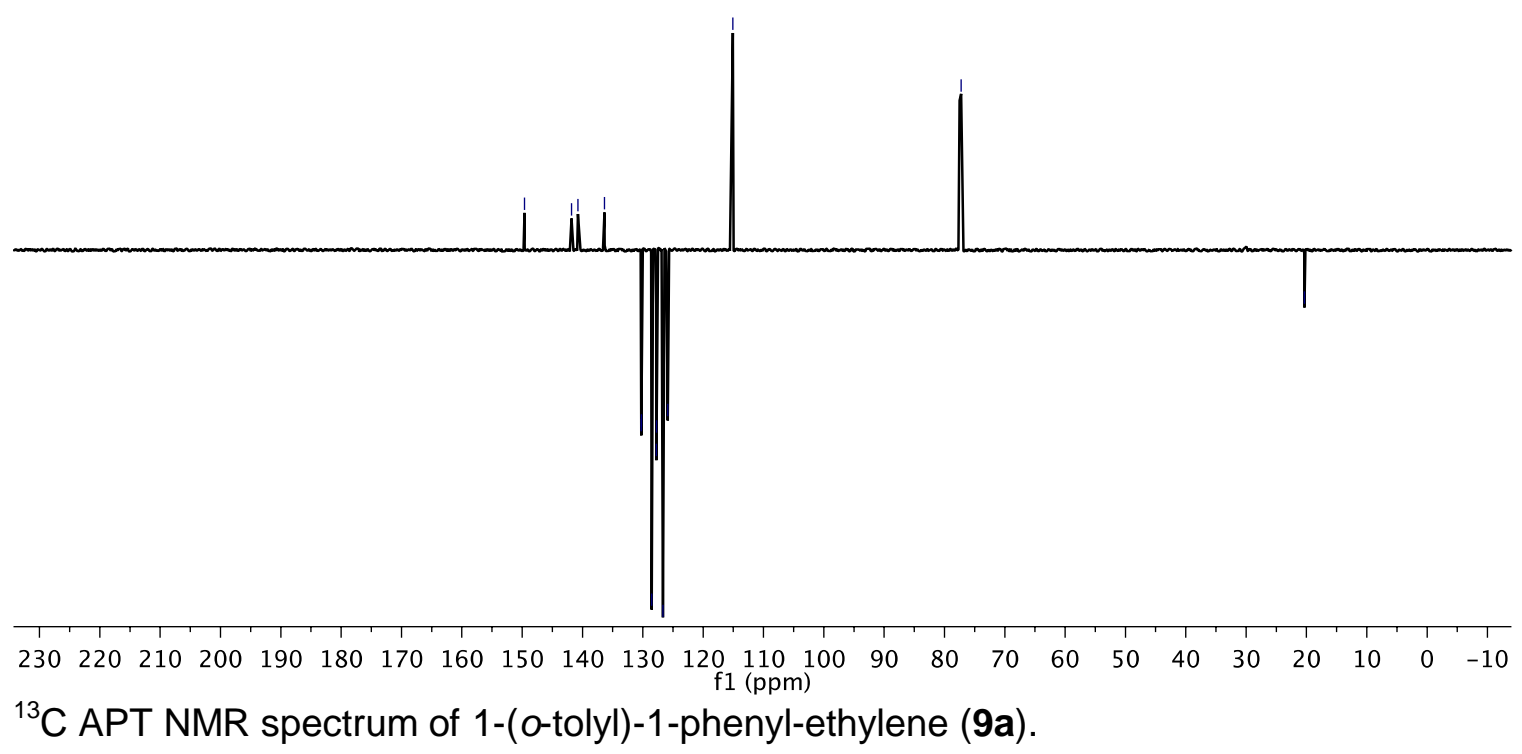




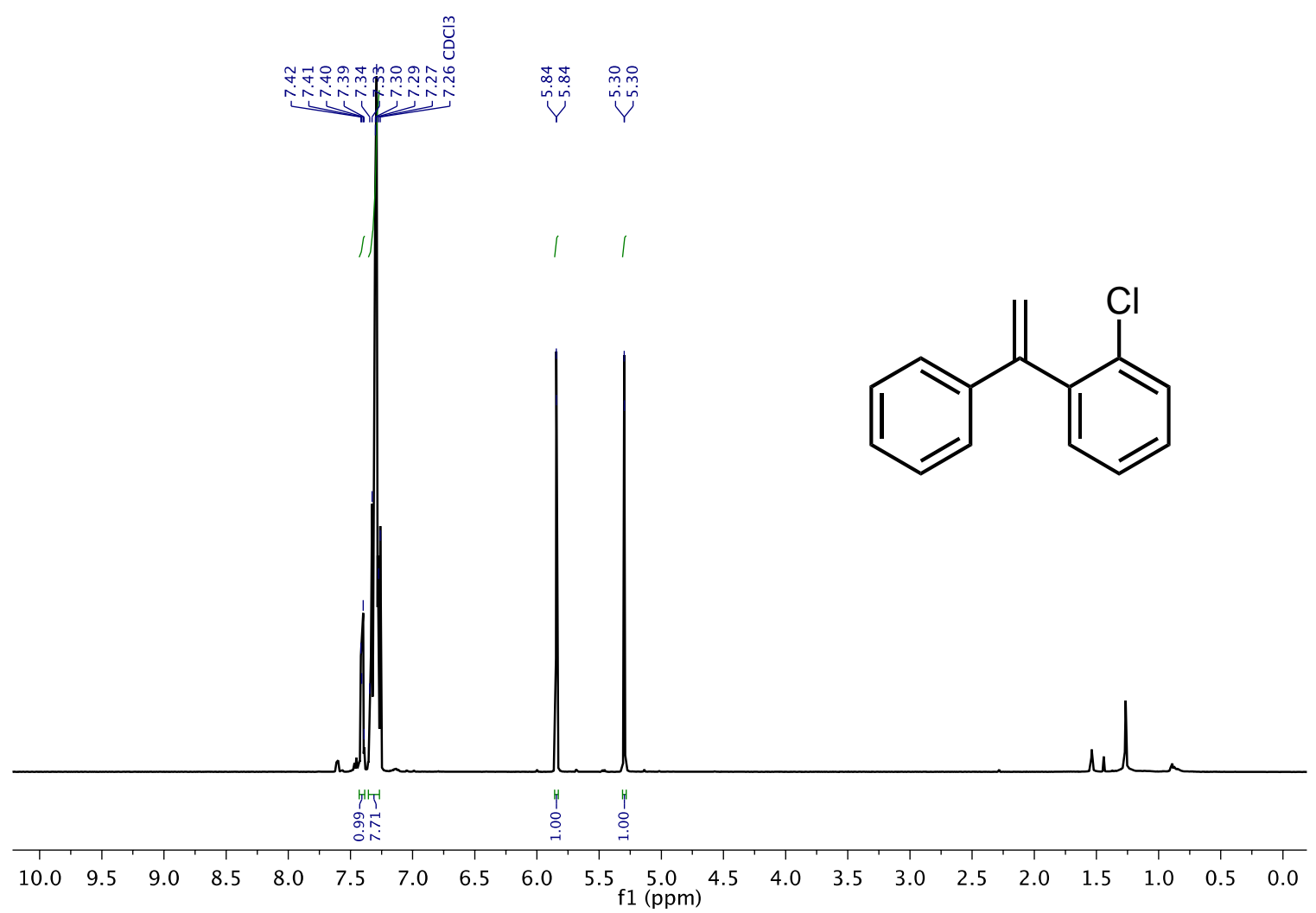

${ }^{1} \mathrm{H}$ NMR spectrum of 1-(o-chloro)-1-phenyl-ethylene (9b).

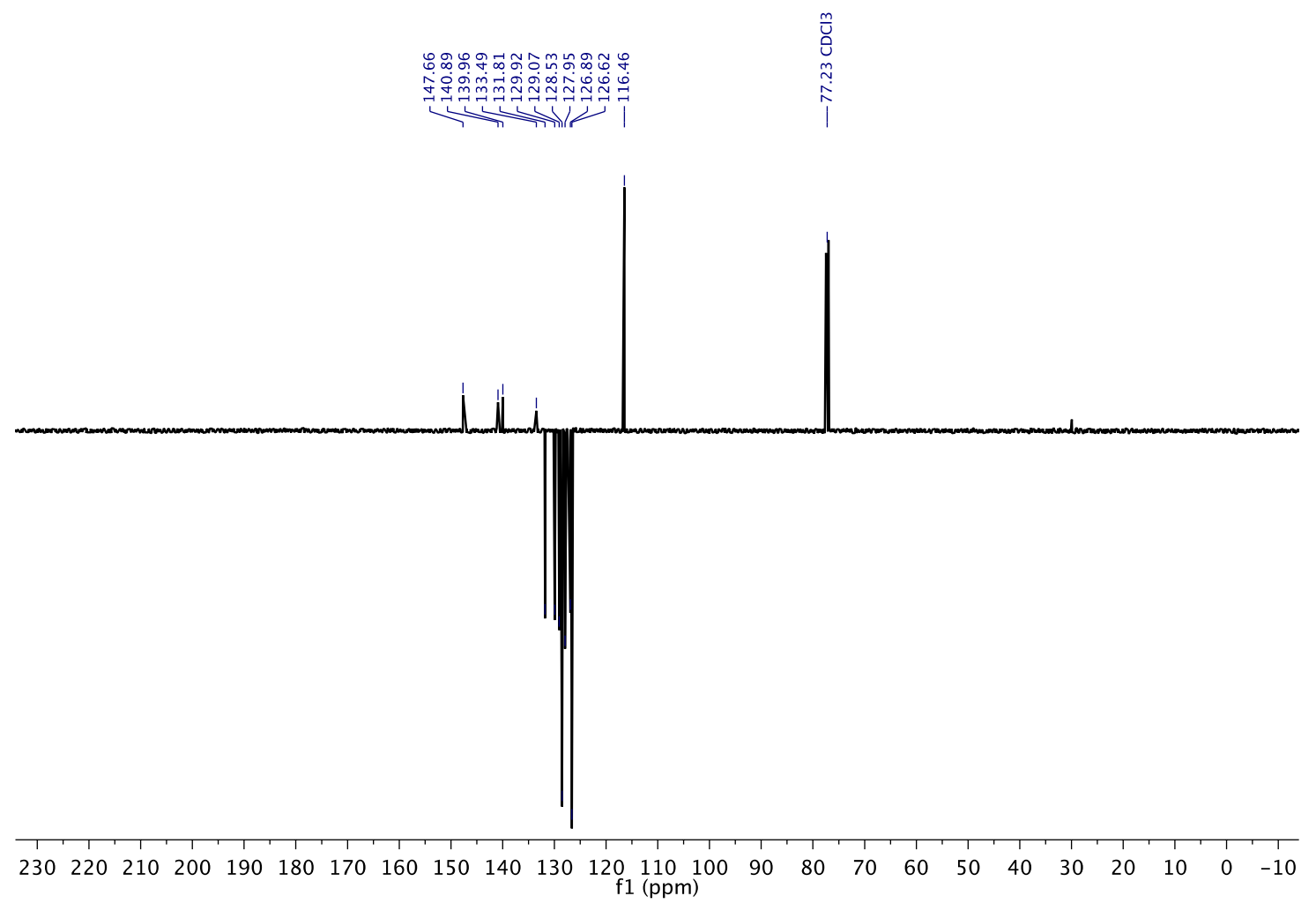

${ }^{13} \mathrm{C}$ APT NMR spectrum of 1-(o-chloro)-1-phenyl-ethylene (9b). 


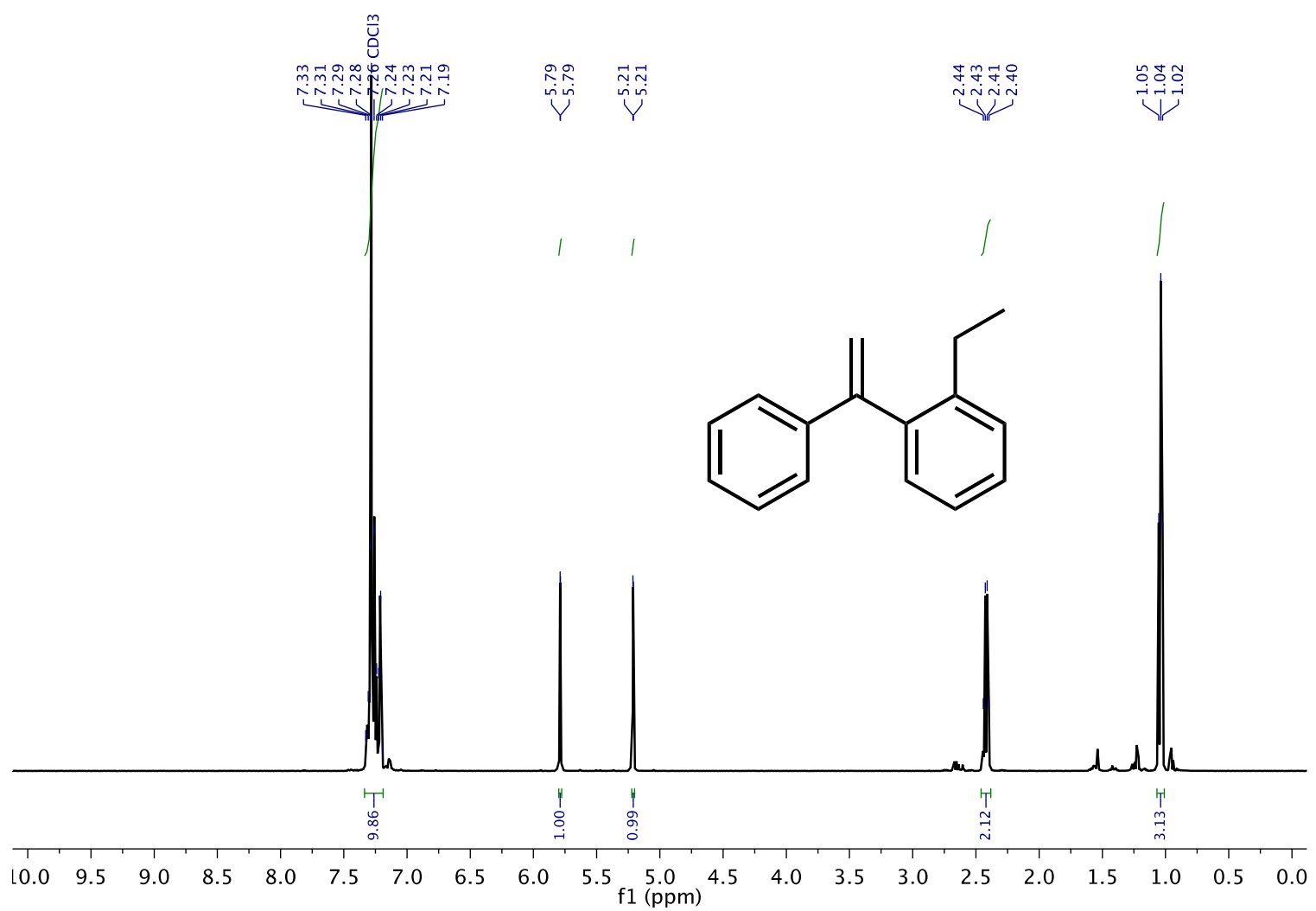

${ }^{1} \mathrm{H}$ NMR spectrum of 1-(o-ethyl)-1-phenyl-ethylene (9c).

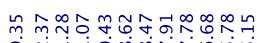

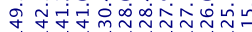

|रे
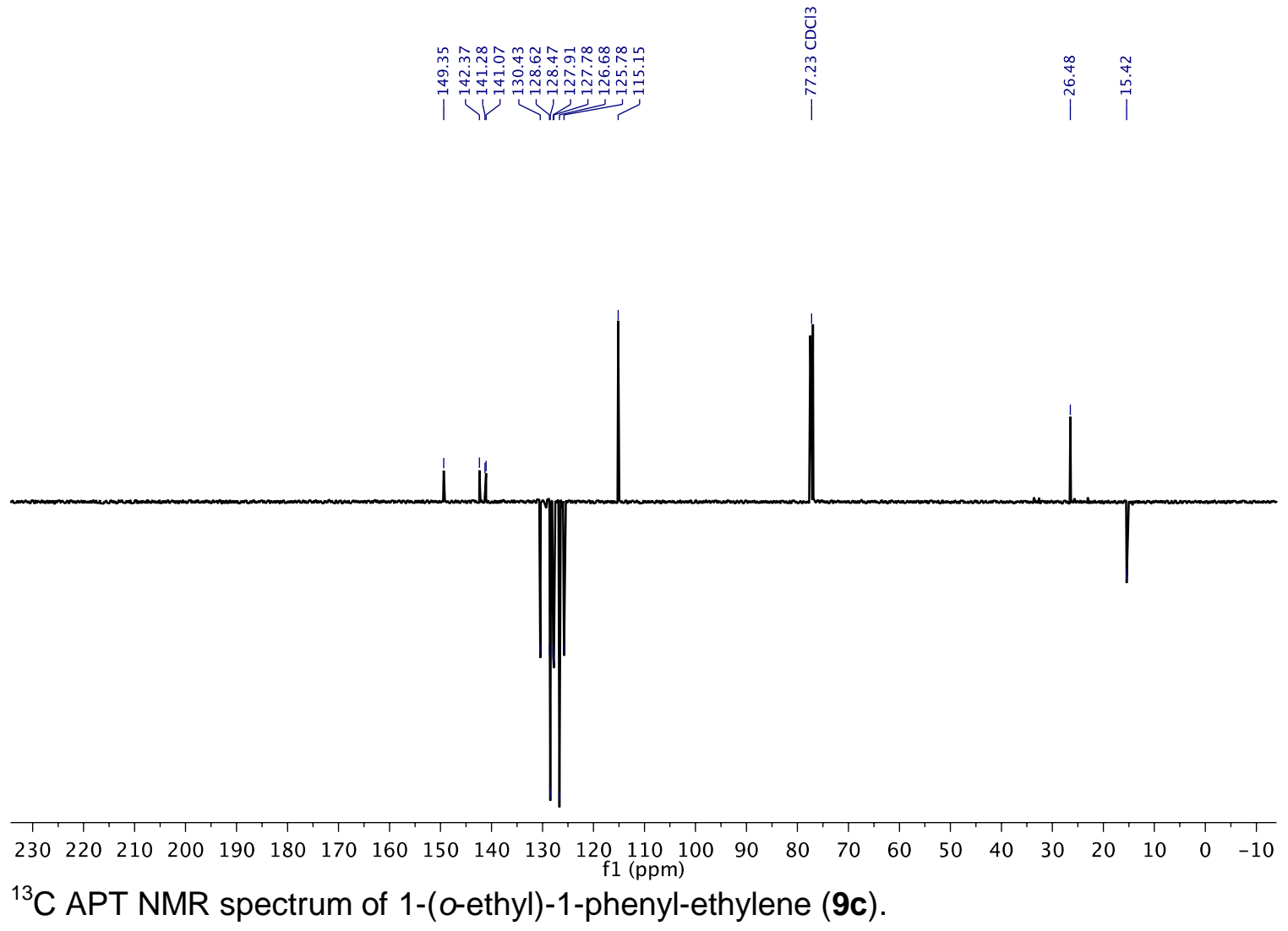


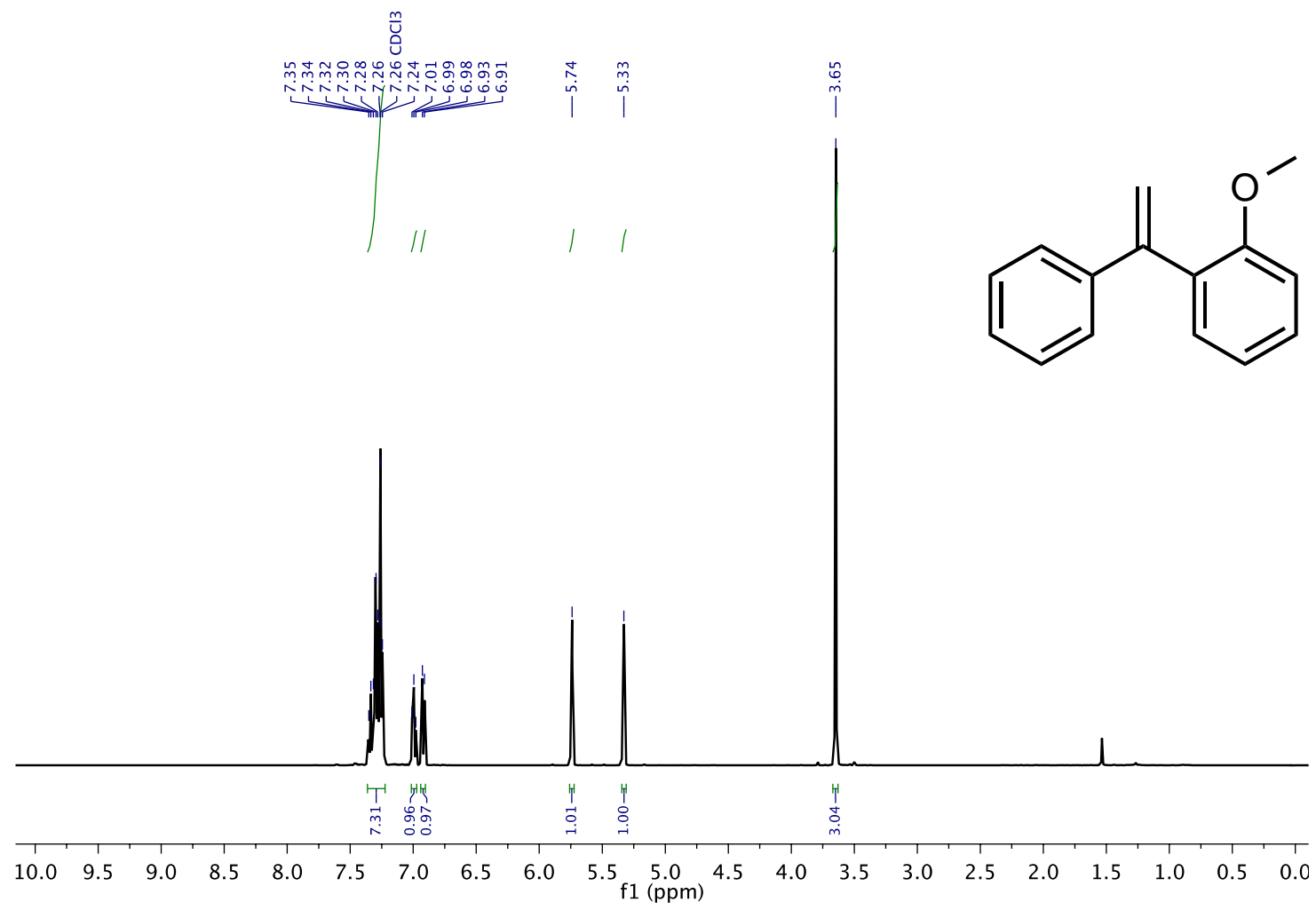

${ }^{1} \mathrm{H}$ NMR spectrum of 1-(o-methoxy)-1-phenyl-ethylene (9d).
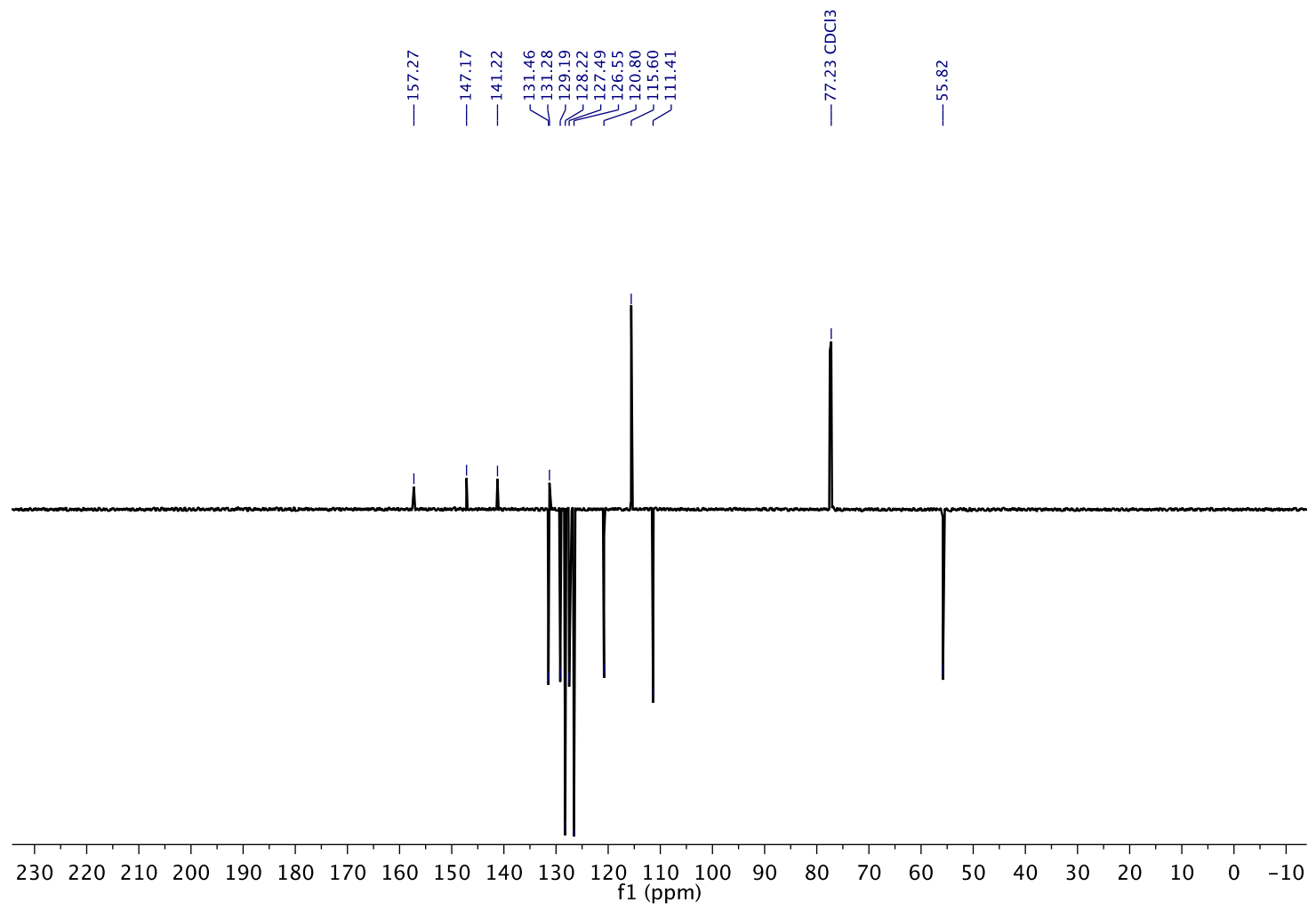

${ }^{13} \mathrm{C}$ APT NMR spectrum of 1-(o-methoxy)-1-phenyl-ethylene (9d). 


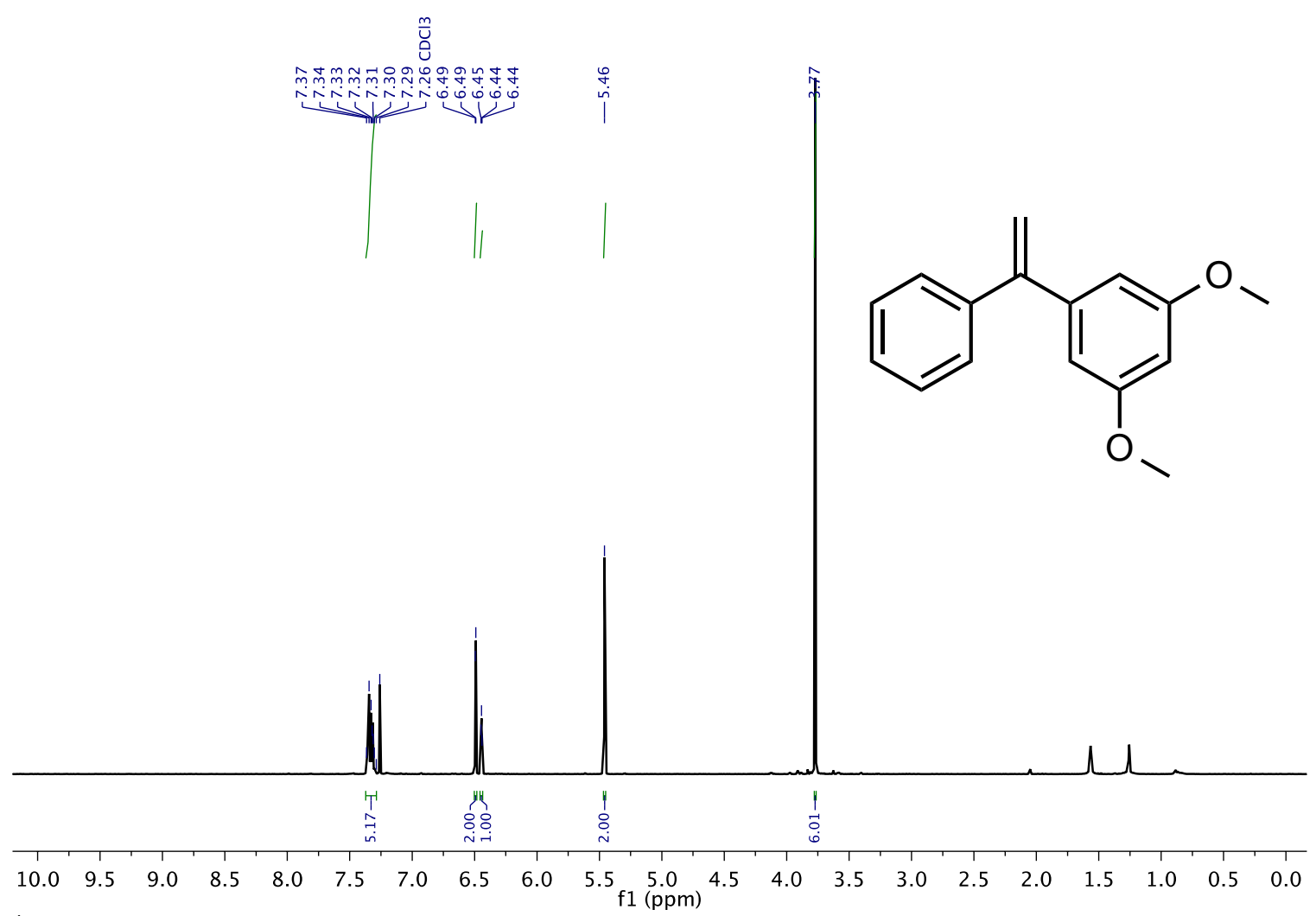

${ }^{1} \mathrm{H}$ NMR spectrum of 1-phenyl-1-(m,m-dimethoxyphenyl)-ethylene (11).

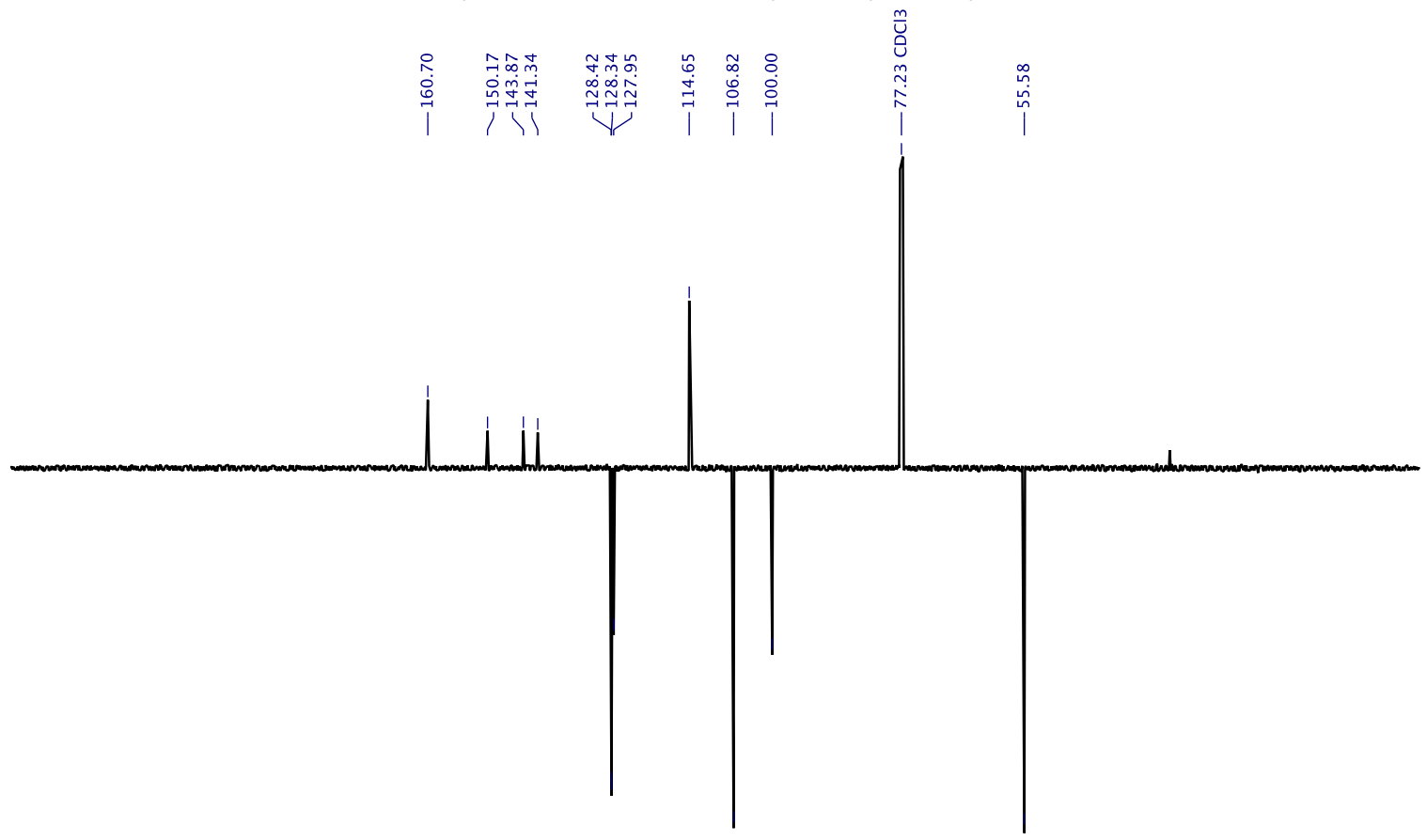

$\begin{array}{llllllllllllllllllllllllllll}230 & 220 & 210 & 200 & 190 & 180 & 170 & 160 & 150 & 140 & 130 & 120 & 110 & 100 & 90 & 80 & 70 & 60 & 50 & 40 & 30 & 20 & 10 & 0 & -10\end{array}$

${ }^{13} \mathrm{C}$ APT NMR spectrum of 1-phenyl-1-(m,m-dimethoxyphenyl)-ethylene (11). 


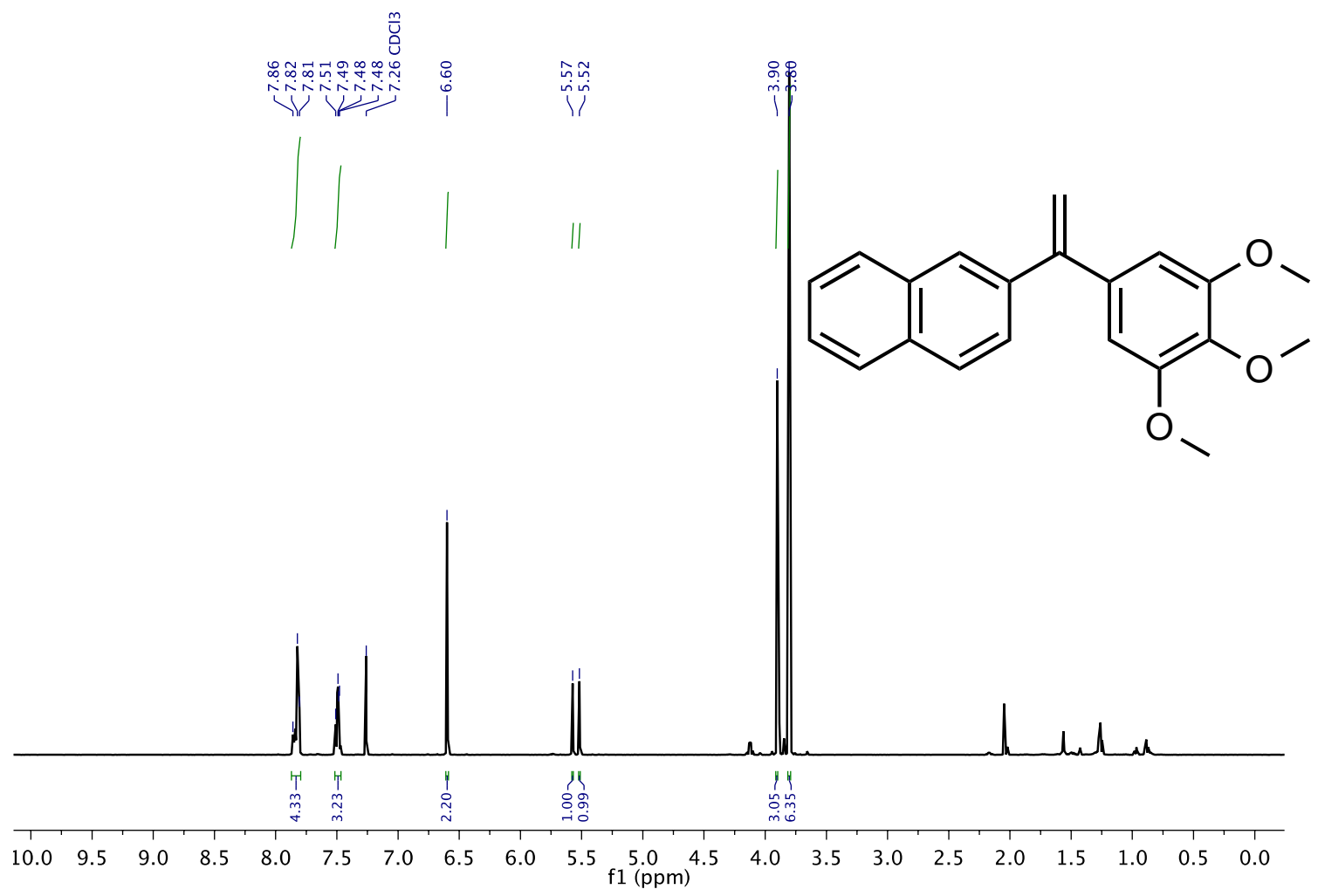

${ }^{1} \mathrm{H}$ NMR spectrum of 1-(2'-naphthyl)-1-( $m, m, p$-trimethoxyphenyl)-ethylene (13).

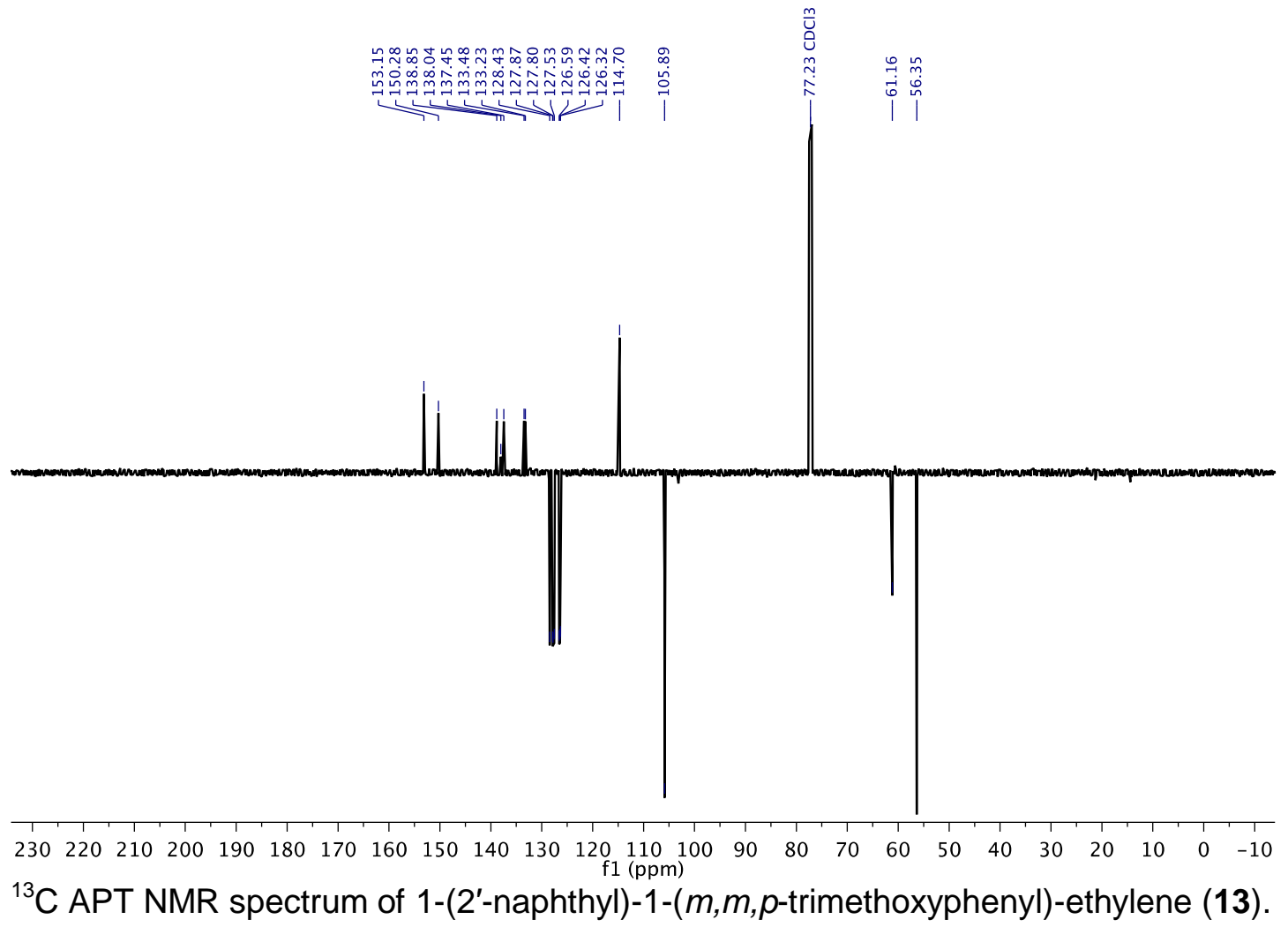



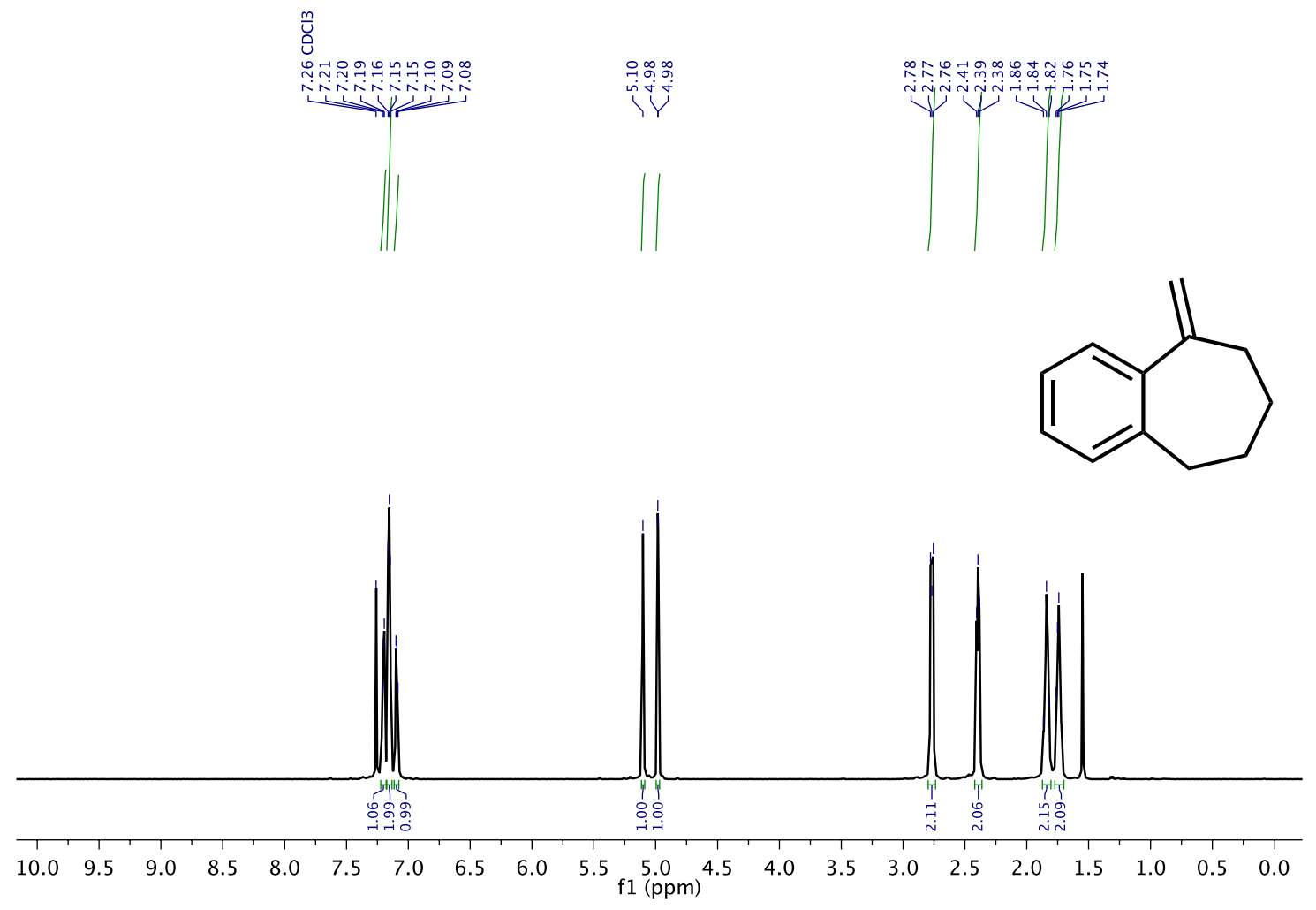

${ }^{1} \mathrm{H}$ NMR spectrum of 1-exo-methylene-benzosuberane (15a).

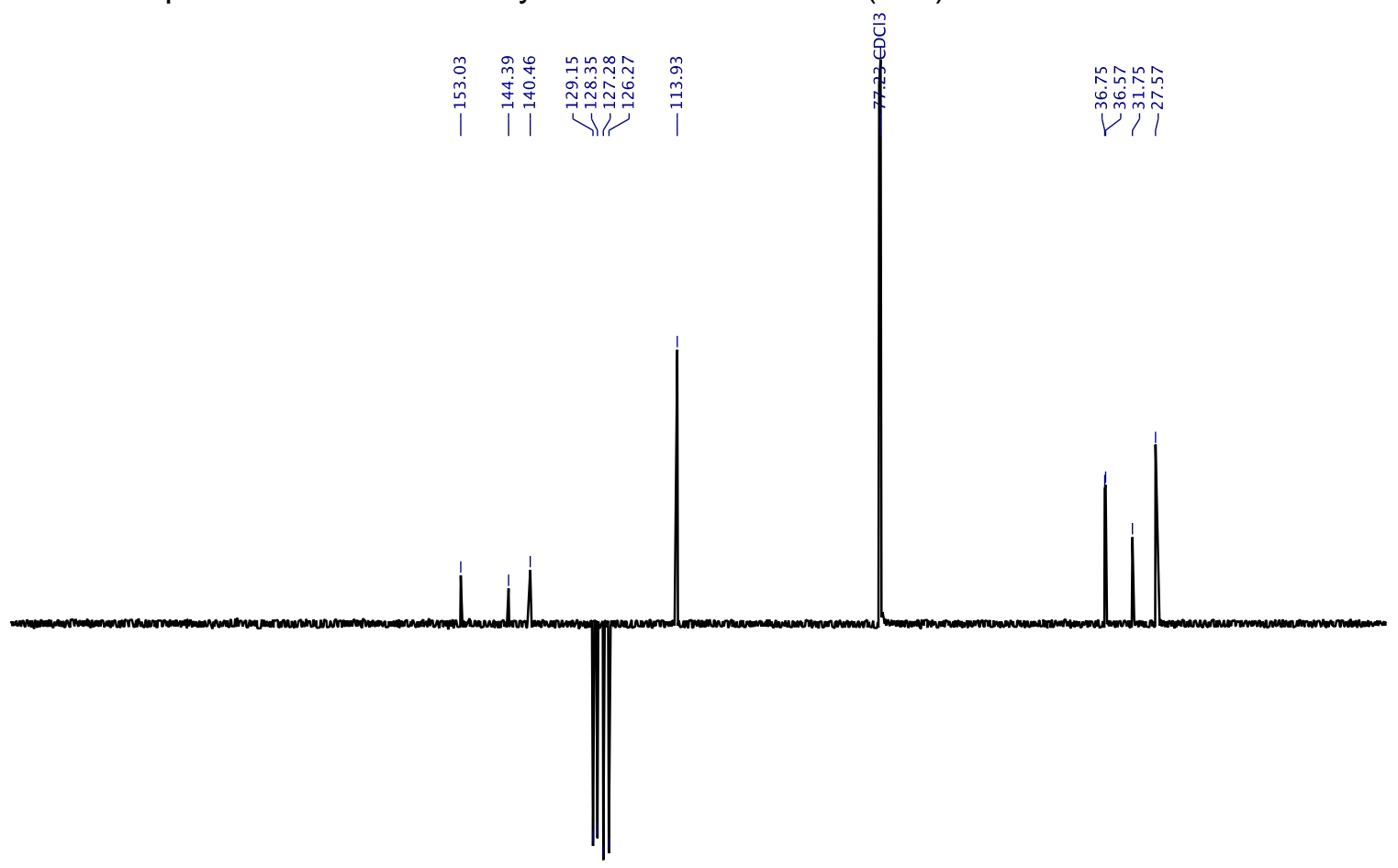

$230220210200190180170160150140130 \quad \begin{array}{llllllllllllllllllllll}120 & 110 & 100 & 90 & 80 & 70 & 60 & 50 & 40 & 30 & 20 & 10 & 0 & -10\end{array}$ ${ }^{13} \mathrm{C}$ APT NMR spectrum of 1-exo-methylene-benzosuberane (15a). 


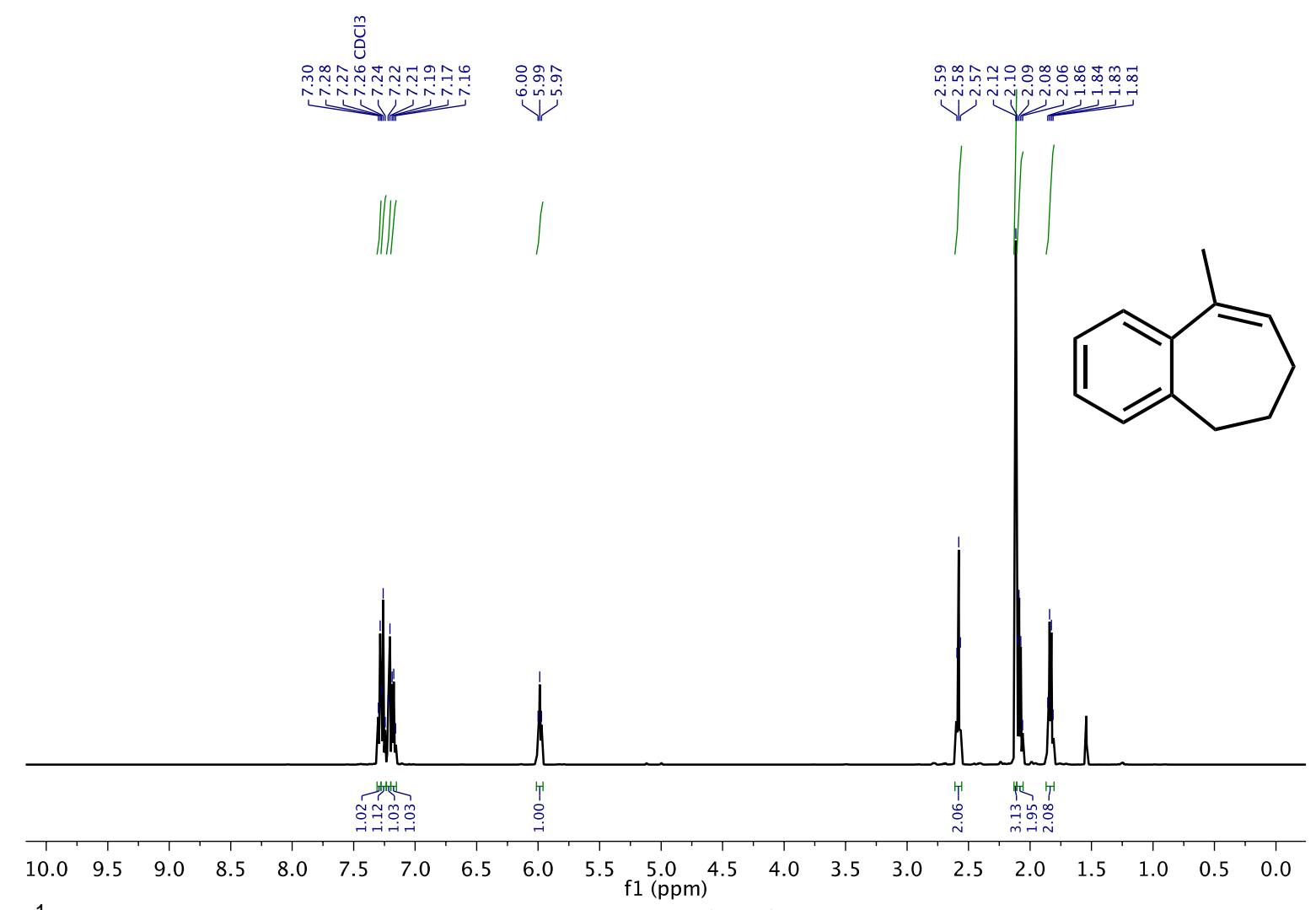

${ }^{1} \mathrm{H}$ NMR spectrum of 1-methyl-benzosuberene (15b).

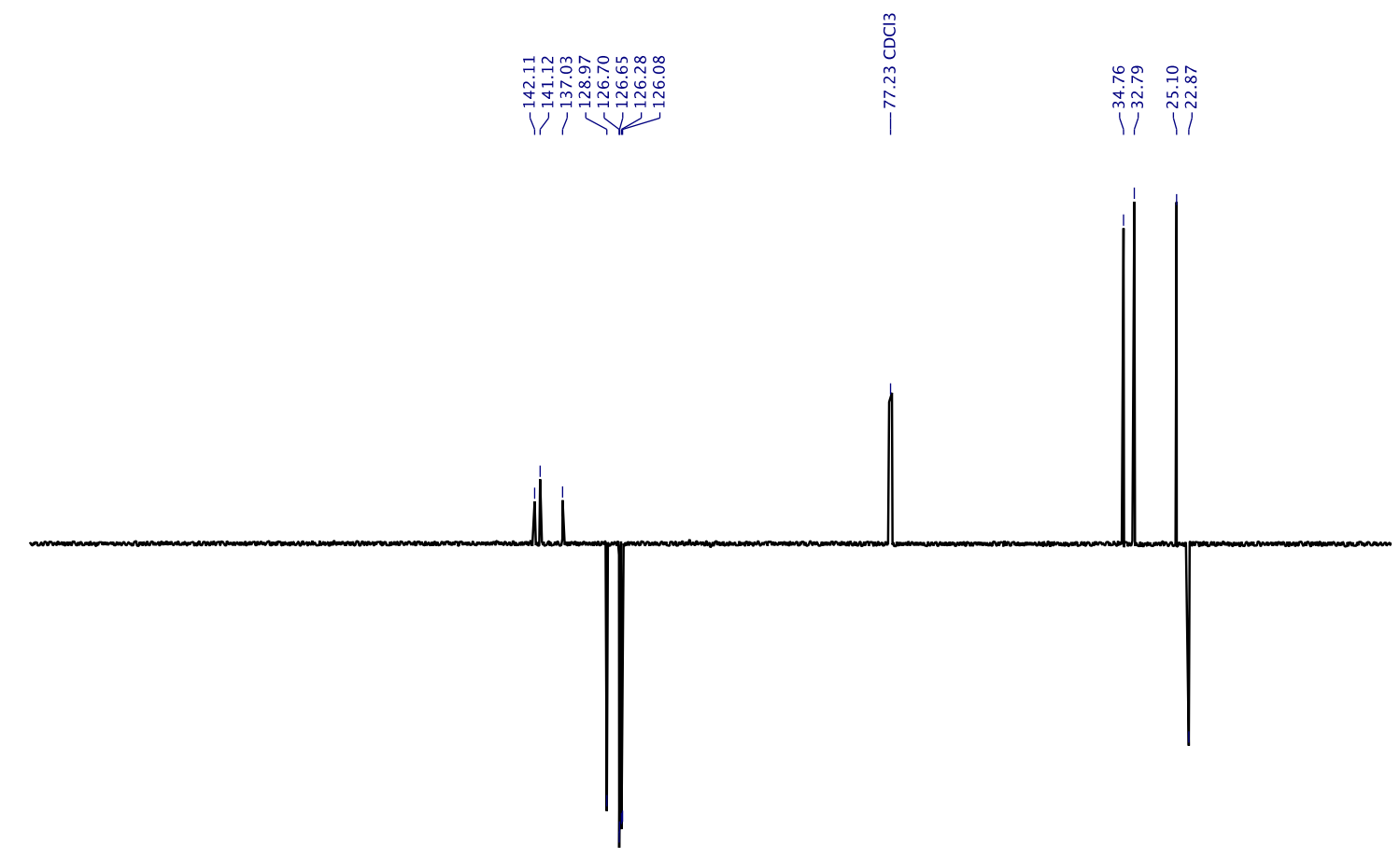

$\begin{array}{lllllllllllllllllllllllllllllllllllllll}230 & 220 & 210 & 200 & 190 & 180 & 170 & 160 & 150 & 140 & 130 & 120 & 110 & 100 & 90 & 80 & 70 & 60 & 50 & 40 & 30 & 20 & 10 & 0 & -10\end{array}$

${ }^{13} \mathrm{C}$ APT NMR spectrum of 1-methyl-benzosuberene (15b). 

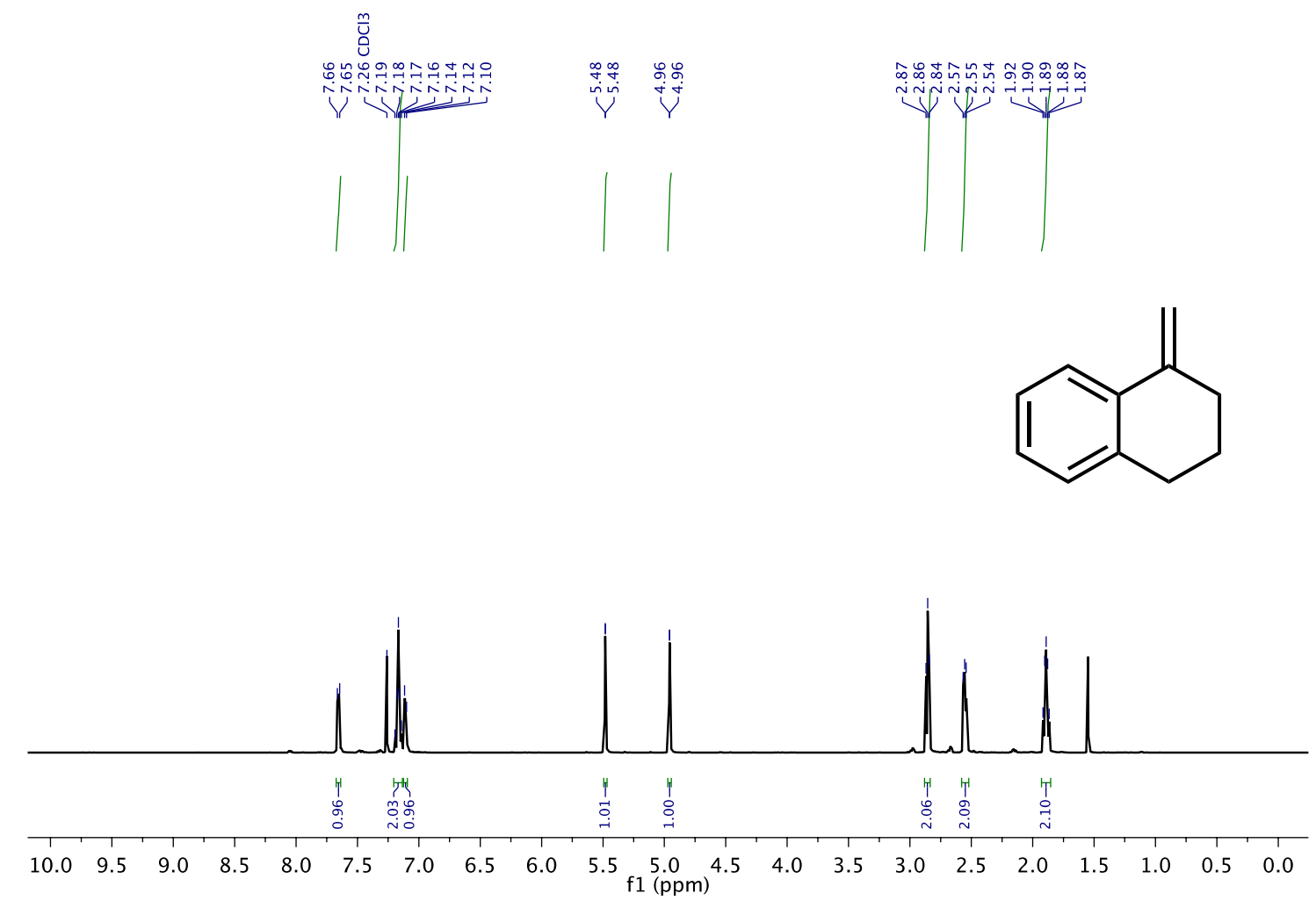

${ }^{1} \mathrm{H}$ NMR spectrum of 1-exo-methylene-dihydronaphthalene (17a).
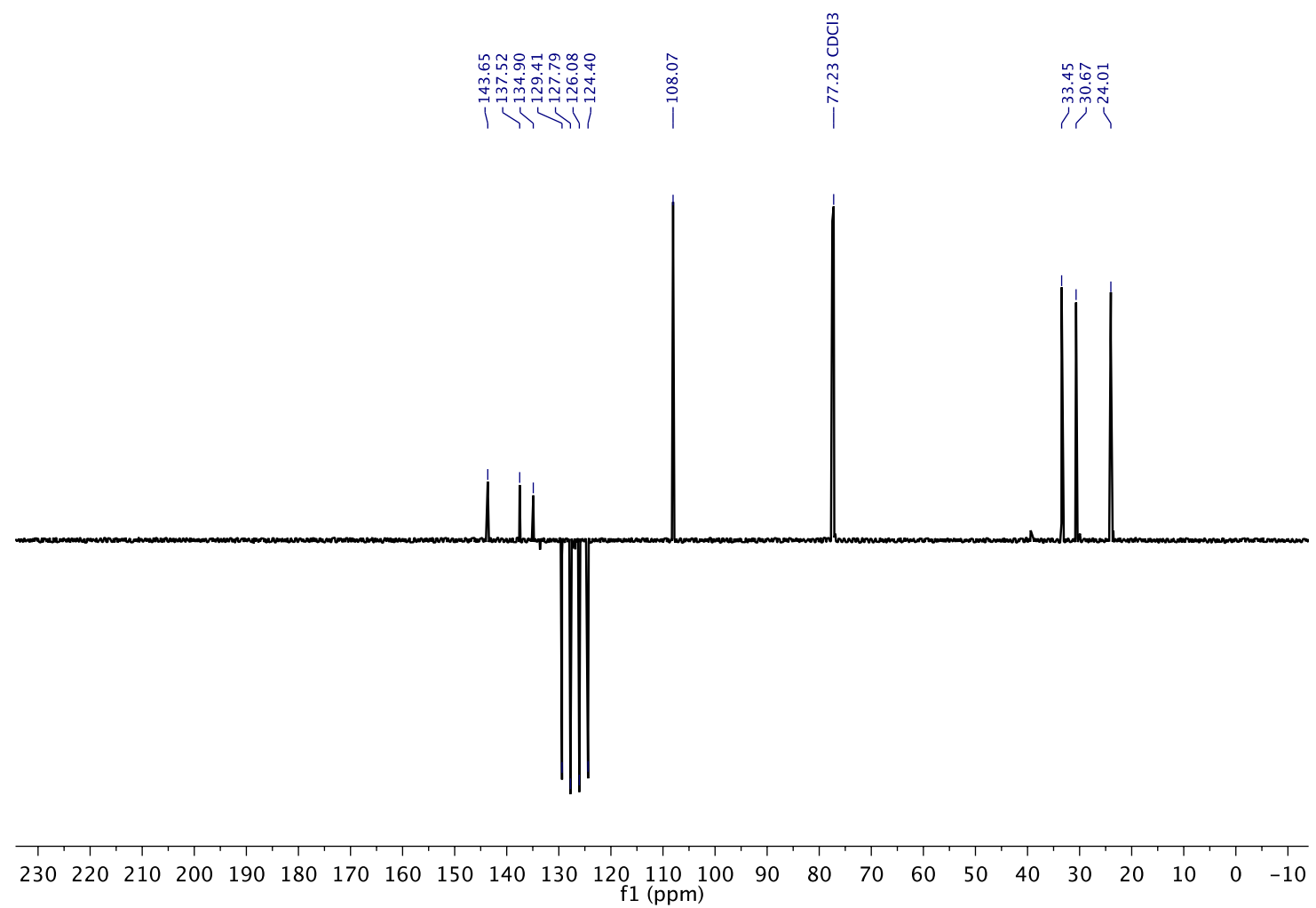

${ }^{13} \mathrm{C}$ APT NMR spectrum of 1-exo-methylene-dihydronaphthalene (17a). 


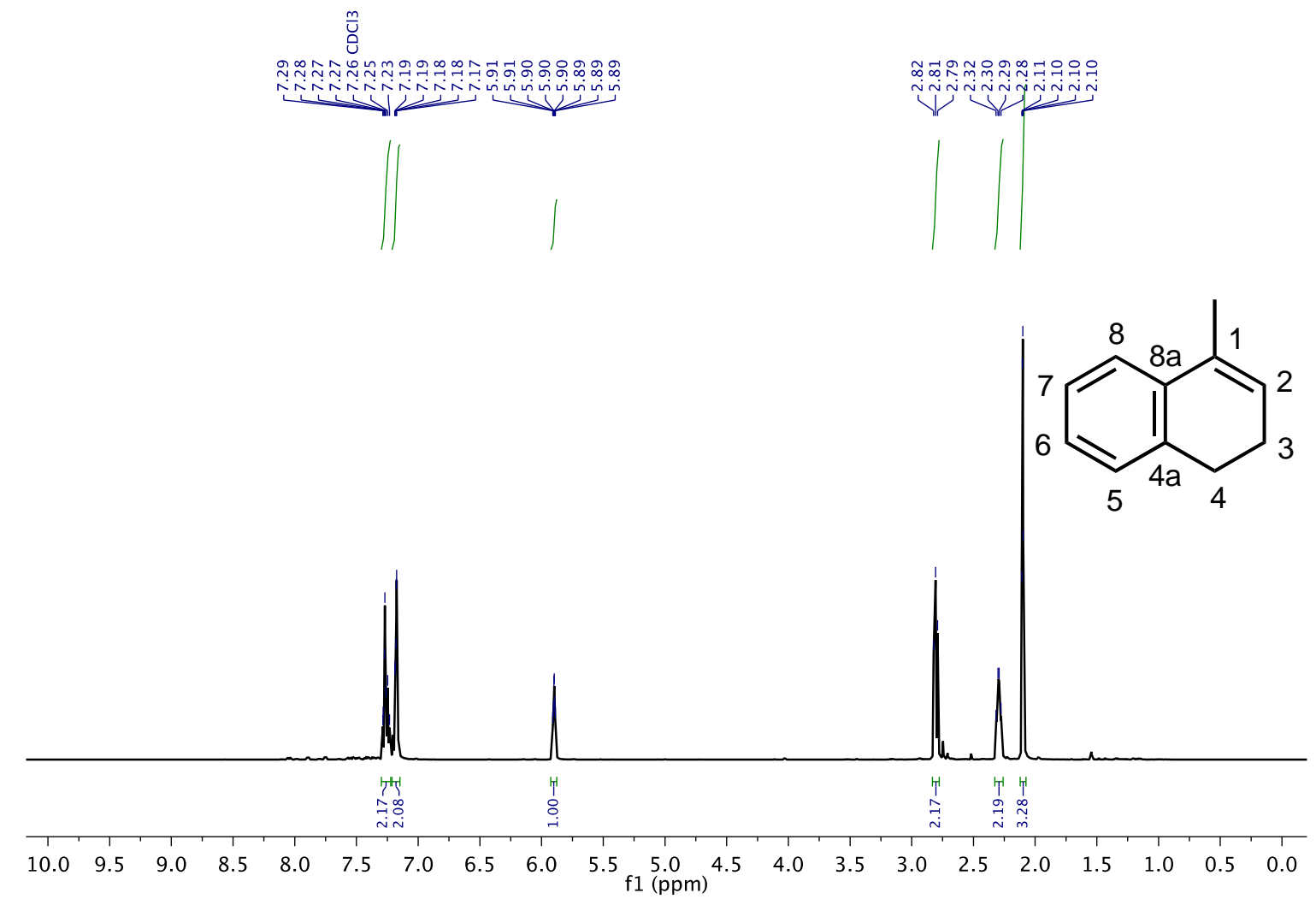

${ }^{1} \mathrm{H}$ NMR spectrum of 1-methyl-3,4-dihydronaphthalene (17b).
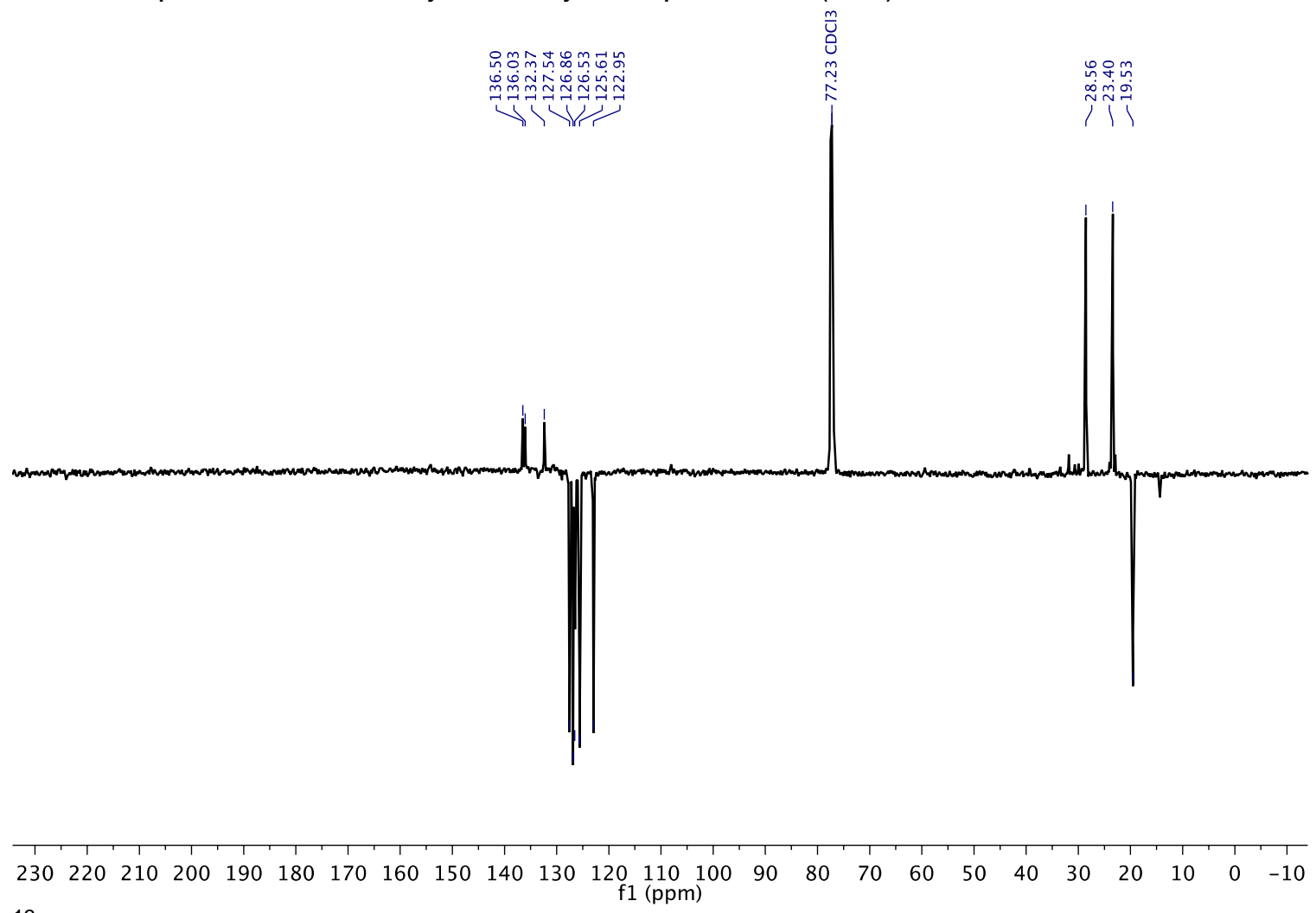

${ }^{13} \mathrm{C}$ APT NMR spectrum of 1-methyl-3,4-dihydronaphthalene (17b). 

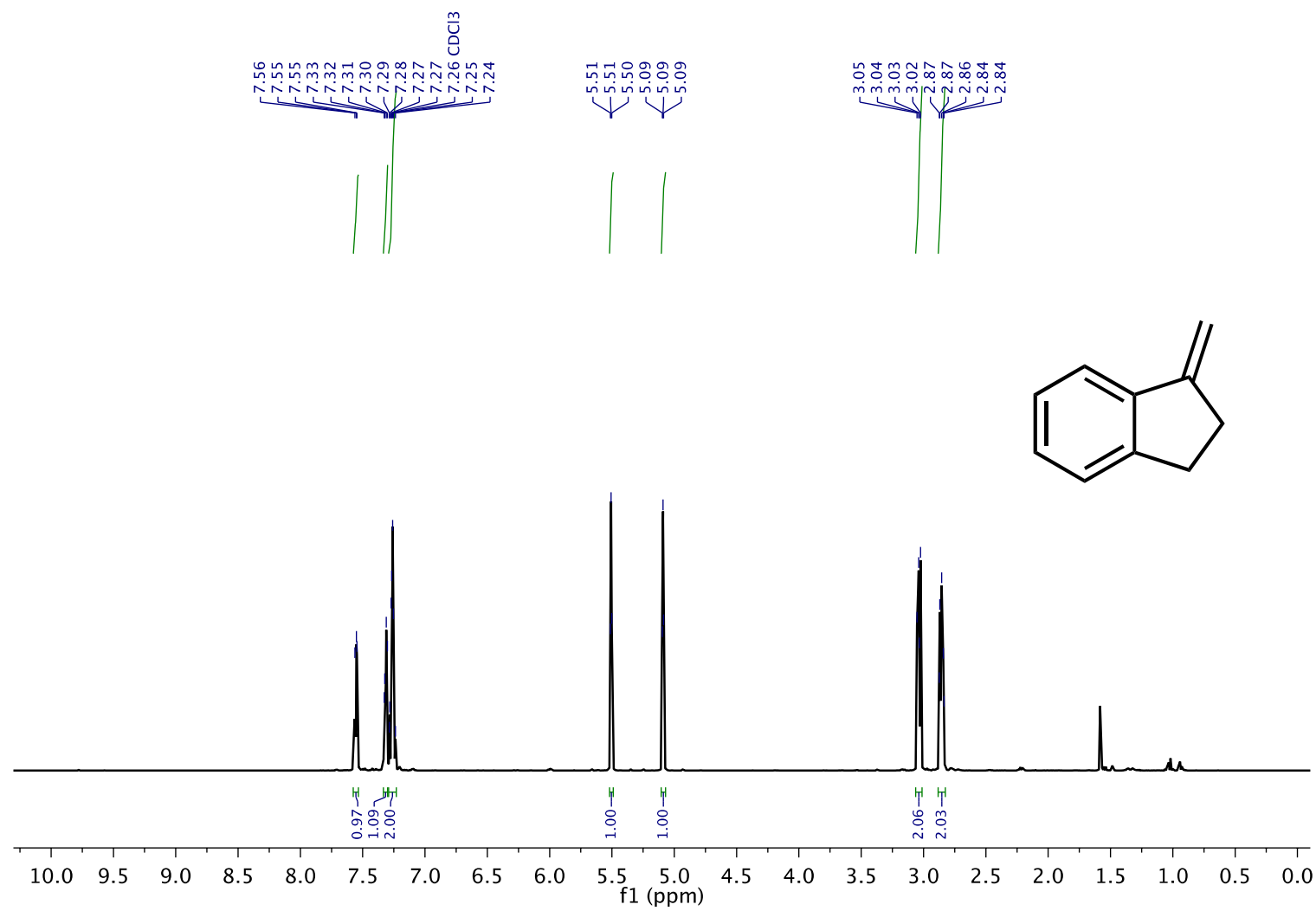

${ }^{1} \mathrm{H}$ NMR spectrum of 1-exo-methylene-indane (19a).
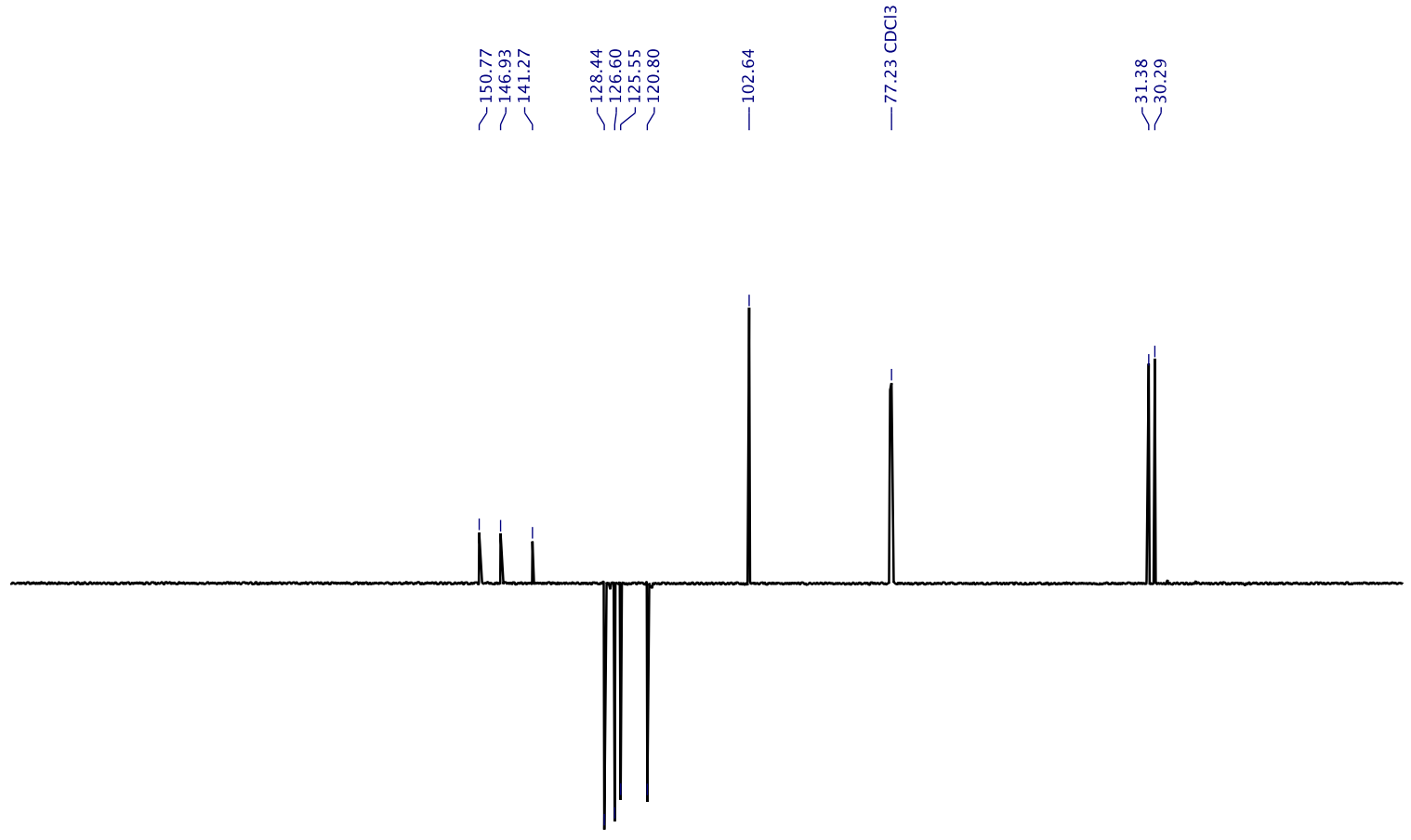

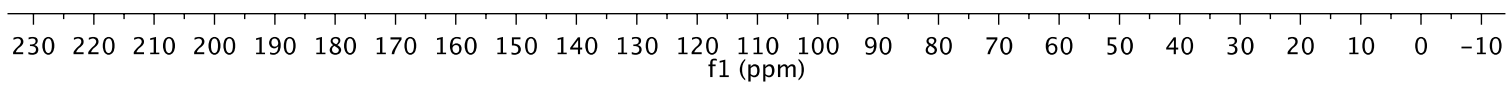
${ }^{13} \mathrm{C}$ APT NMR spectrum of 1-exo-methylene-indane (19a). 


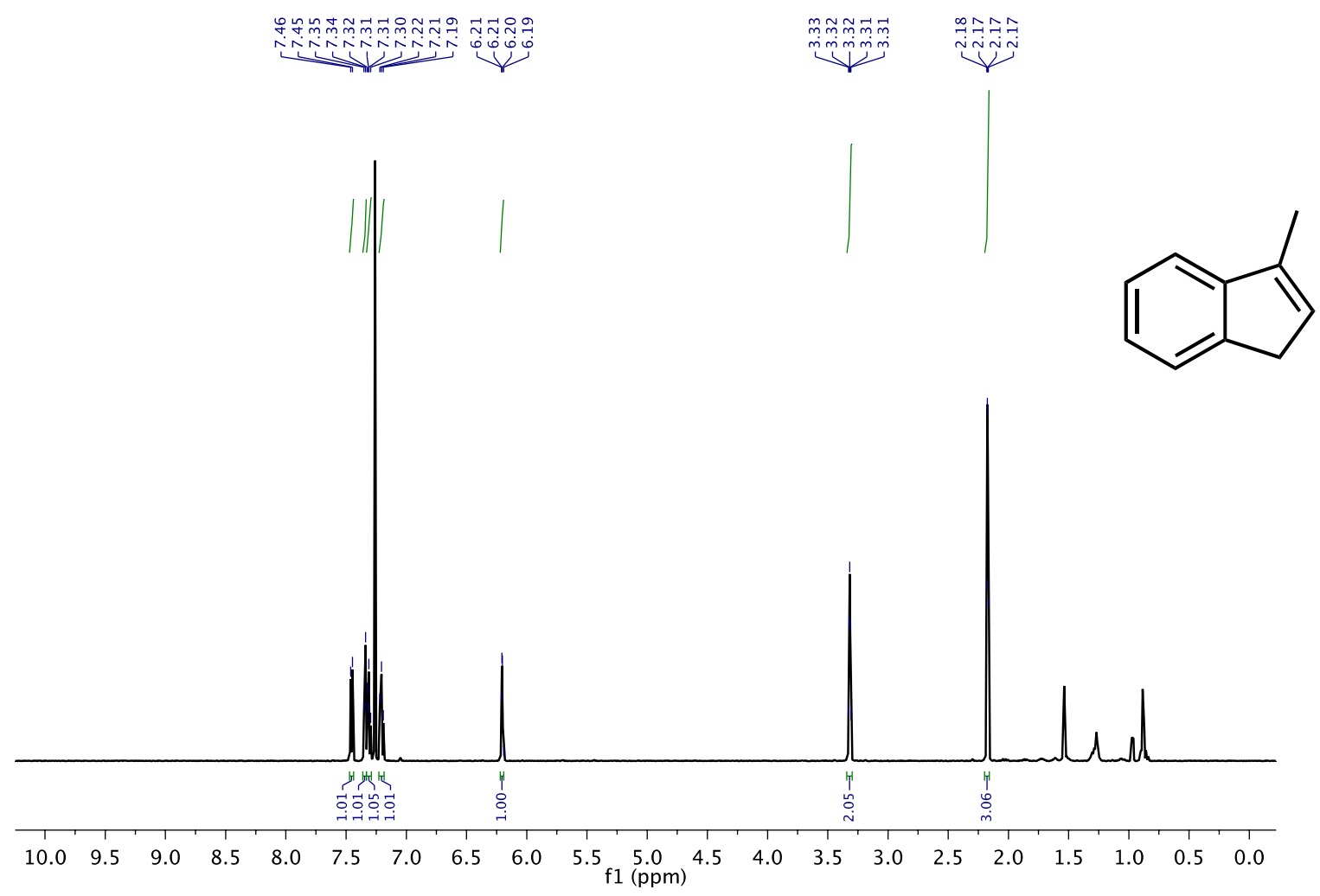

${ }^{1} \mathrm{H}$ NMR spectrum of 3-methyl-1H-indane (19b).

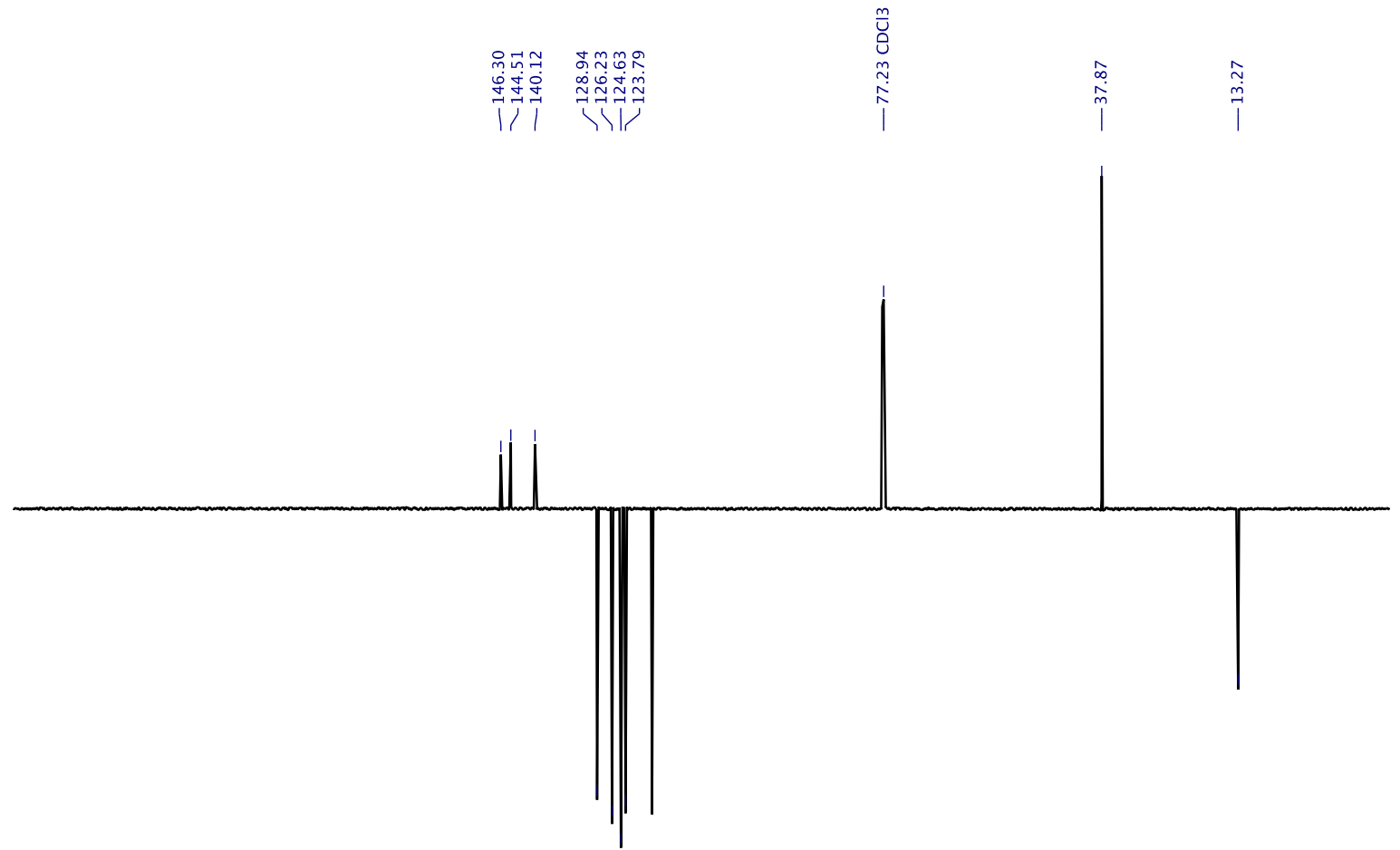

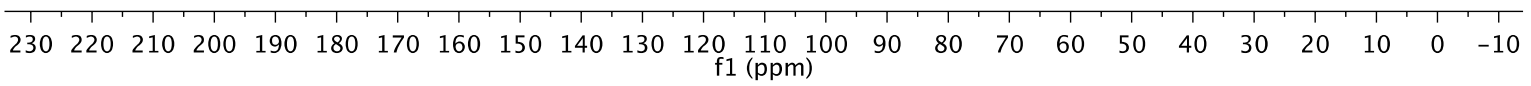
${ }^{13} \mathrm{C}$ APT NMR spectrum of 3-methyl- $1 \mathrm{H}$-indane (19b). 

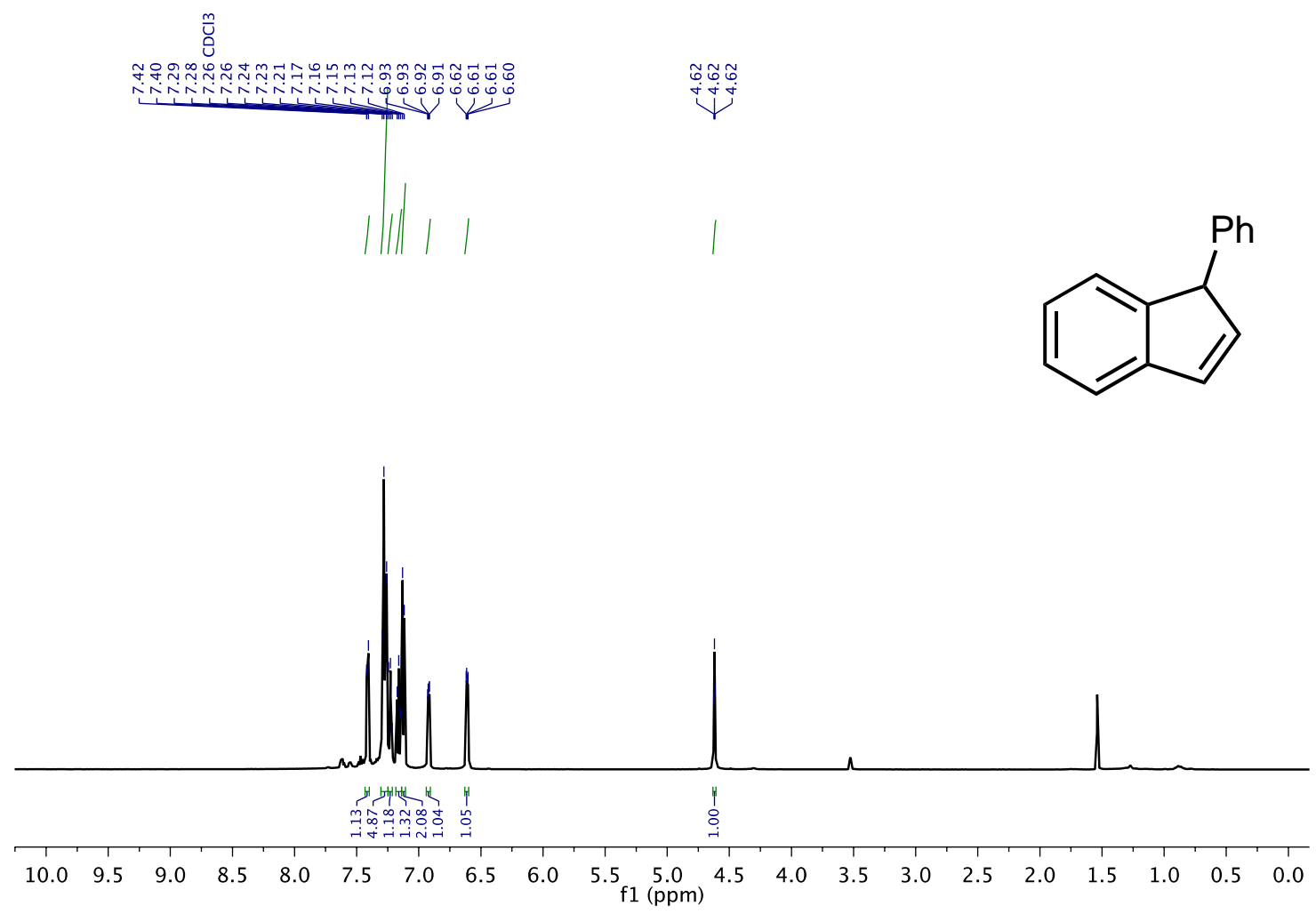

${ }^{1} \mathrm{H}$ NMR spectrum of 1 -phenyl- $1 H$-indene $(\mathbf{1 g})$.
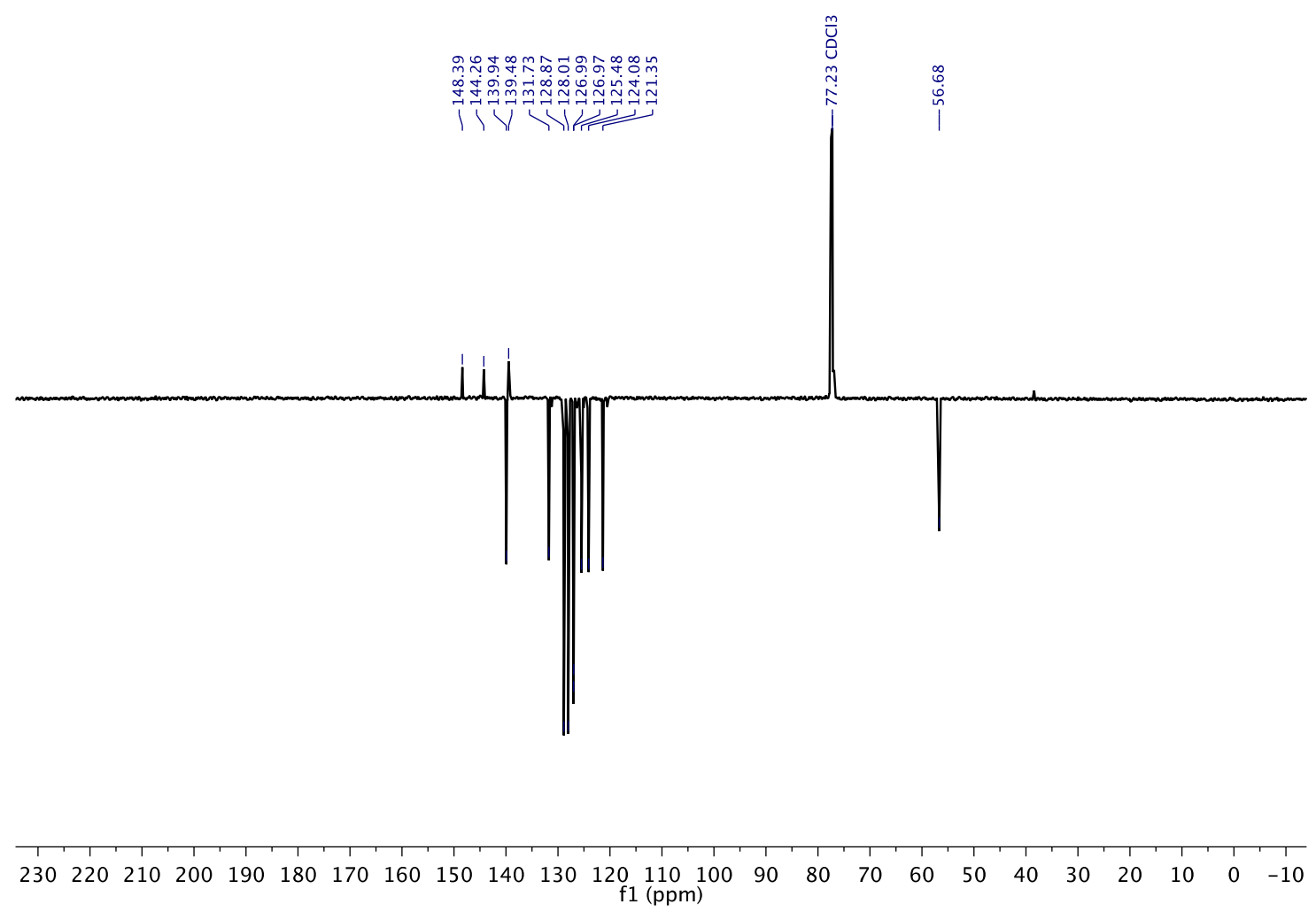

${ }^{13} \mathrm{C}$ APT NMR spectrum of 1 -phenyl-1 $H$-indene $(\mathbf{1 g})$. 

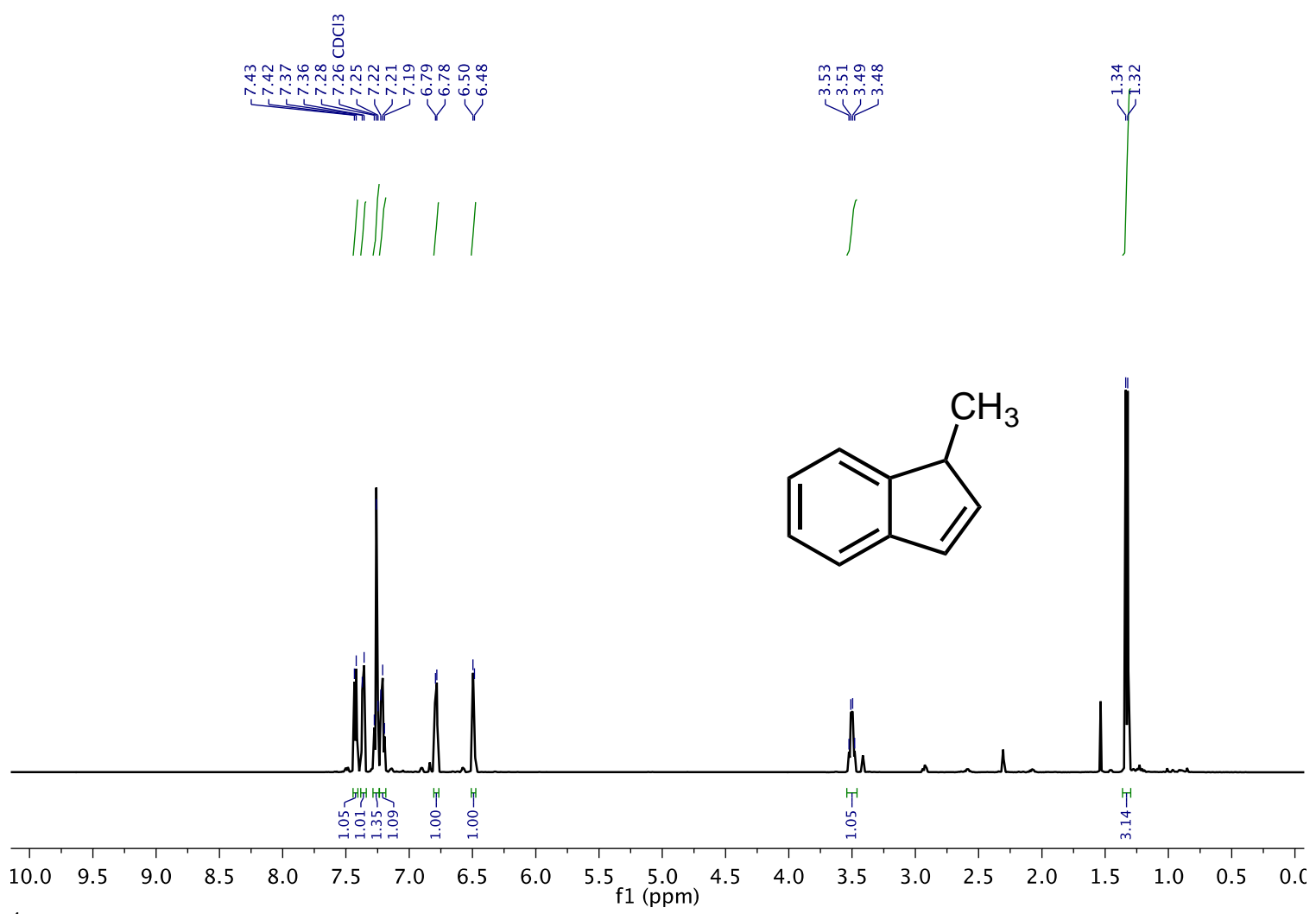

${ }^{1} \mathrm{H}$ NMR spectrum of 1-methyl-1 $\mathrm{H}$-indene (19c).

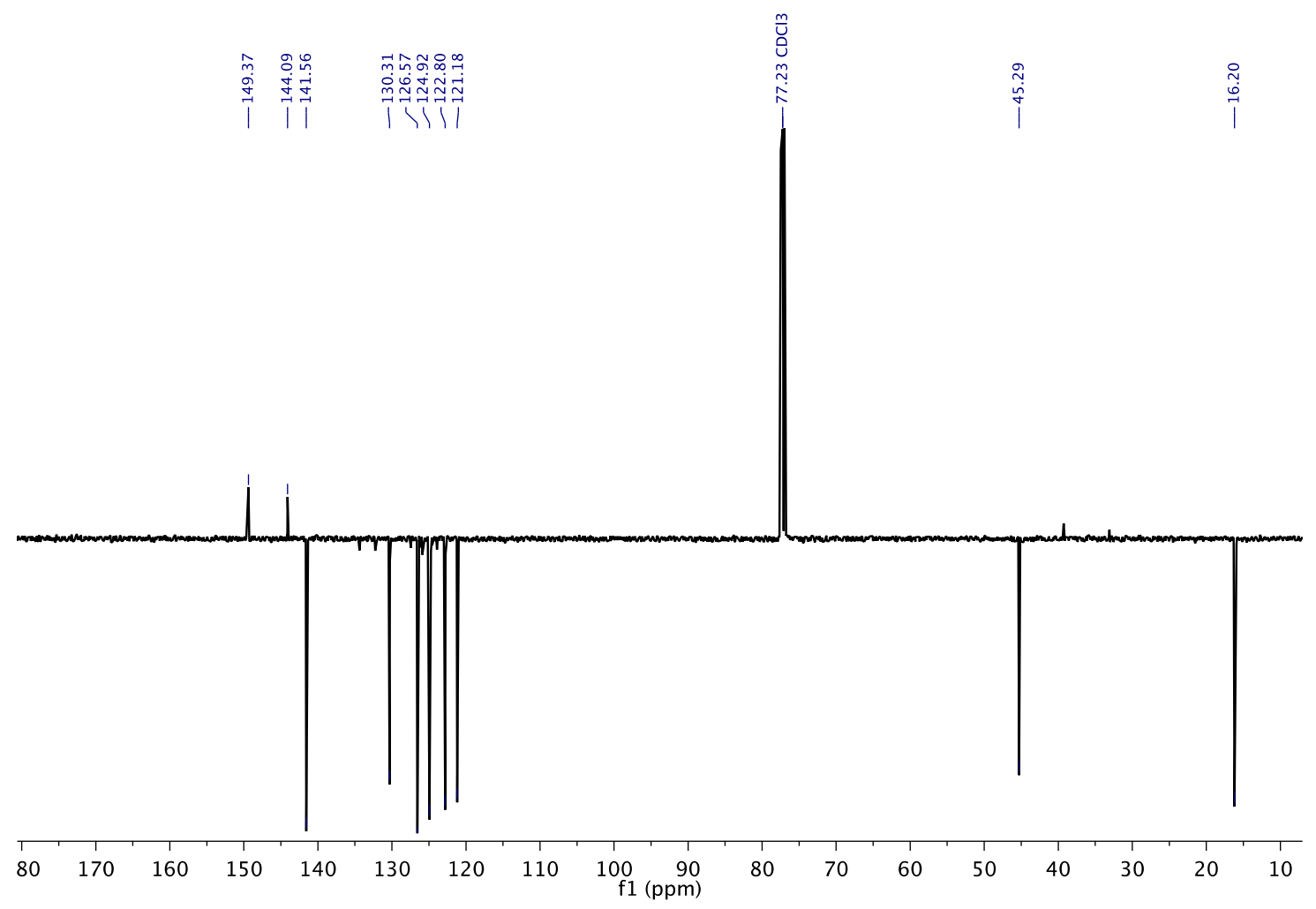

${ }^{13} \mathrm{C}$ APT NMR spectrum of 1 -methyl-1 $H$-indene (19c). 


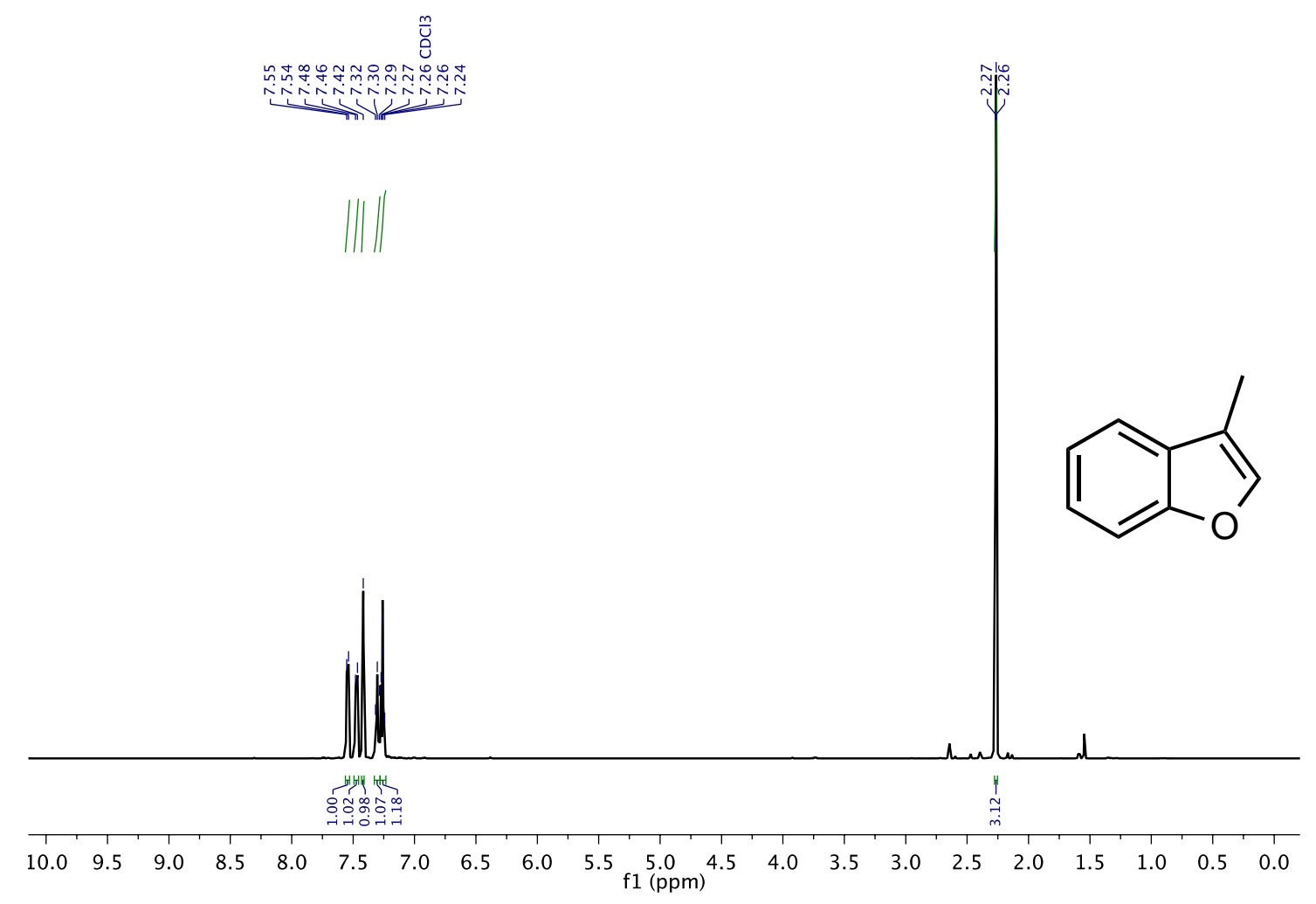

${ }^{1} \mathrm{H}$ NMR spectrum of 3-methylbenzofuran.

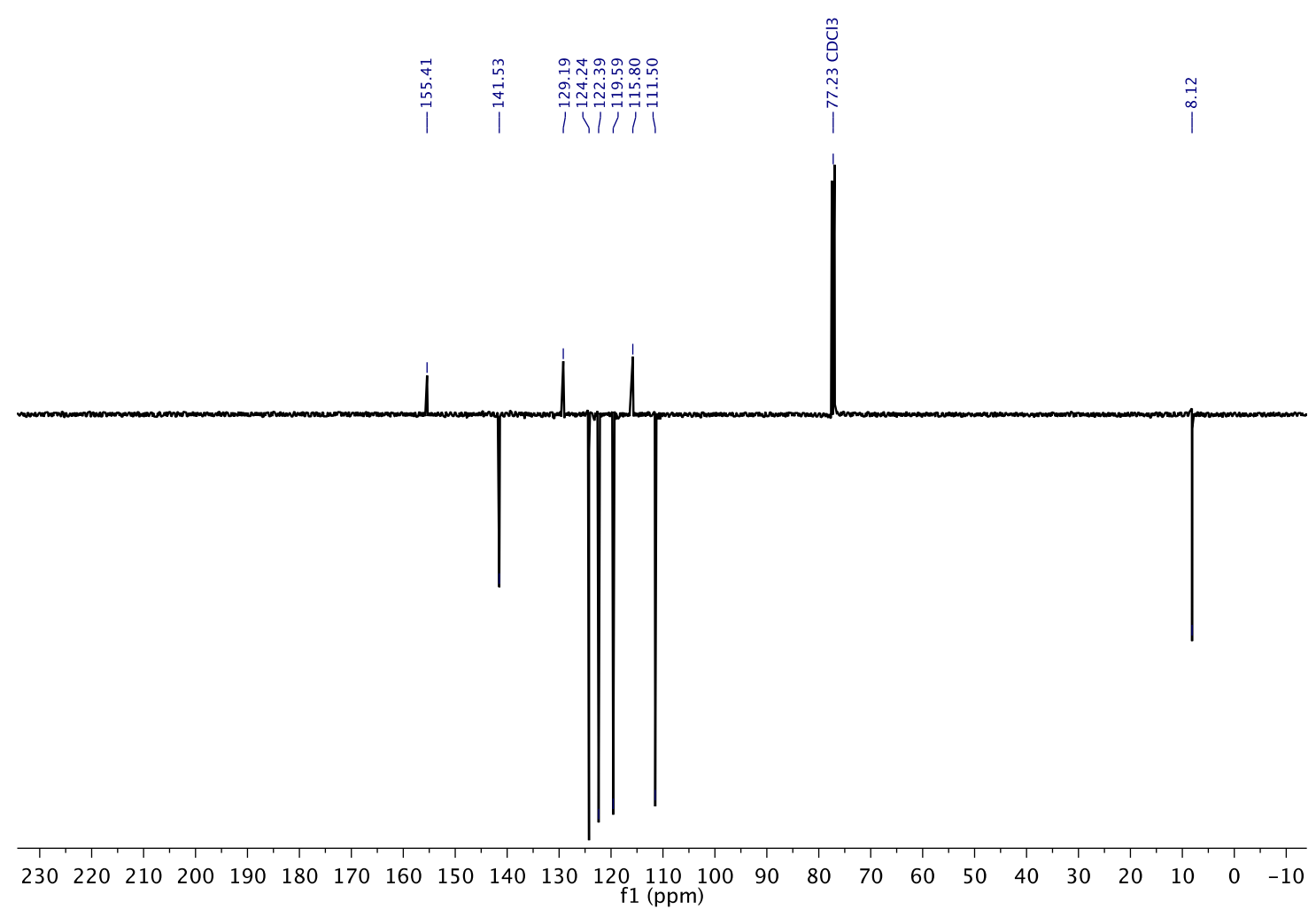

${ }^{13} \mathrm{C}$ APT NMR spectrum of 3-methylbenzofuran. 


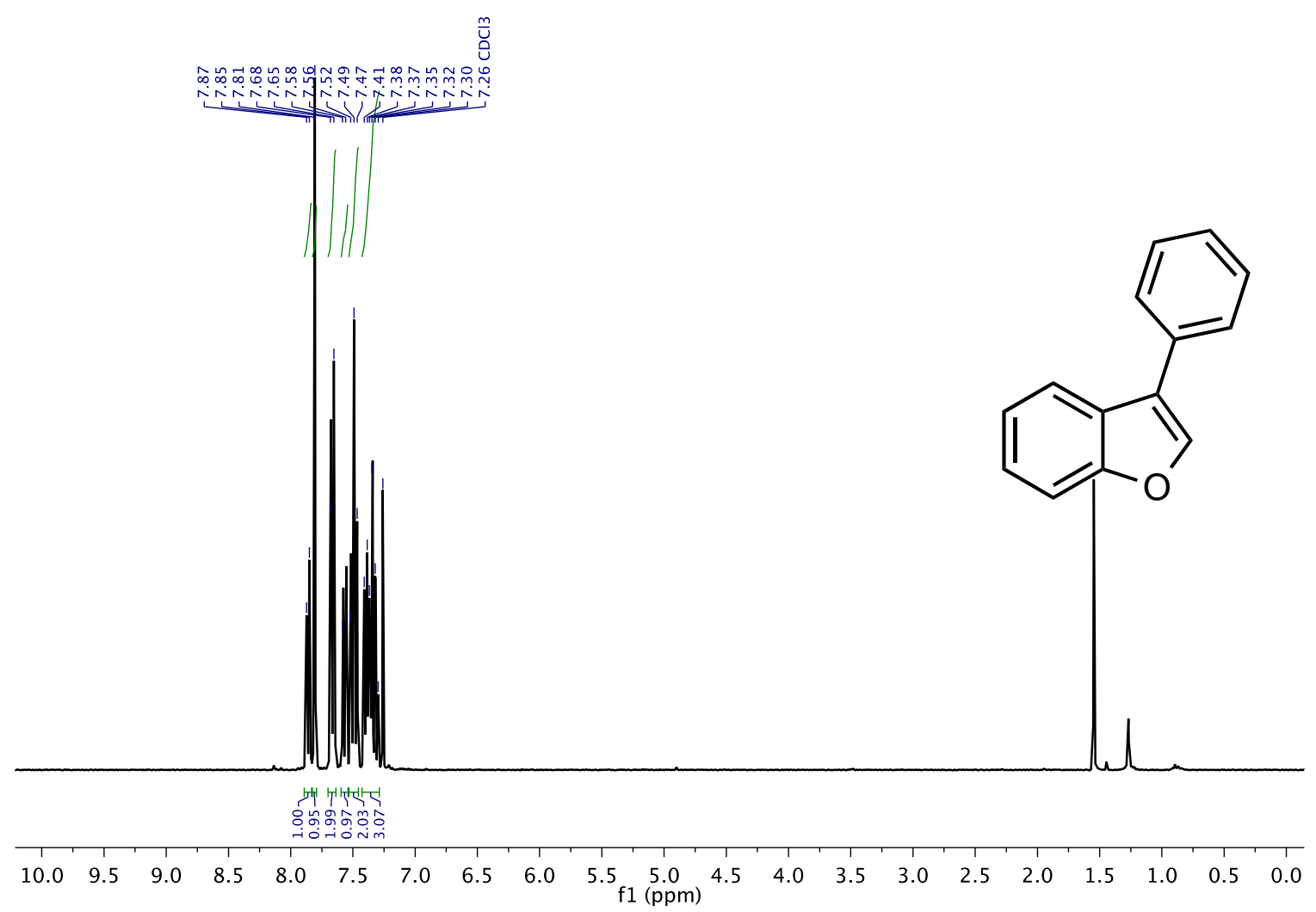

${ }^{1} \mathrm{H}$ NMR spectrum of 3-methylbenzofuran.

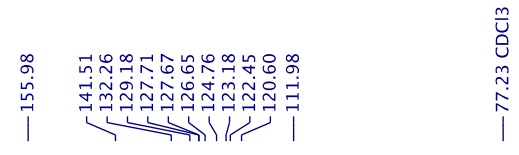

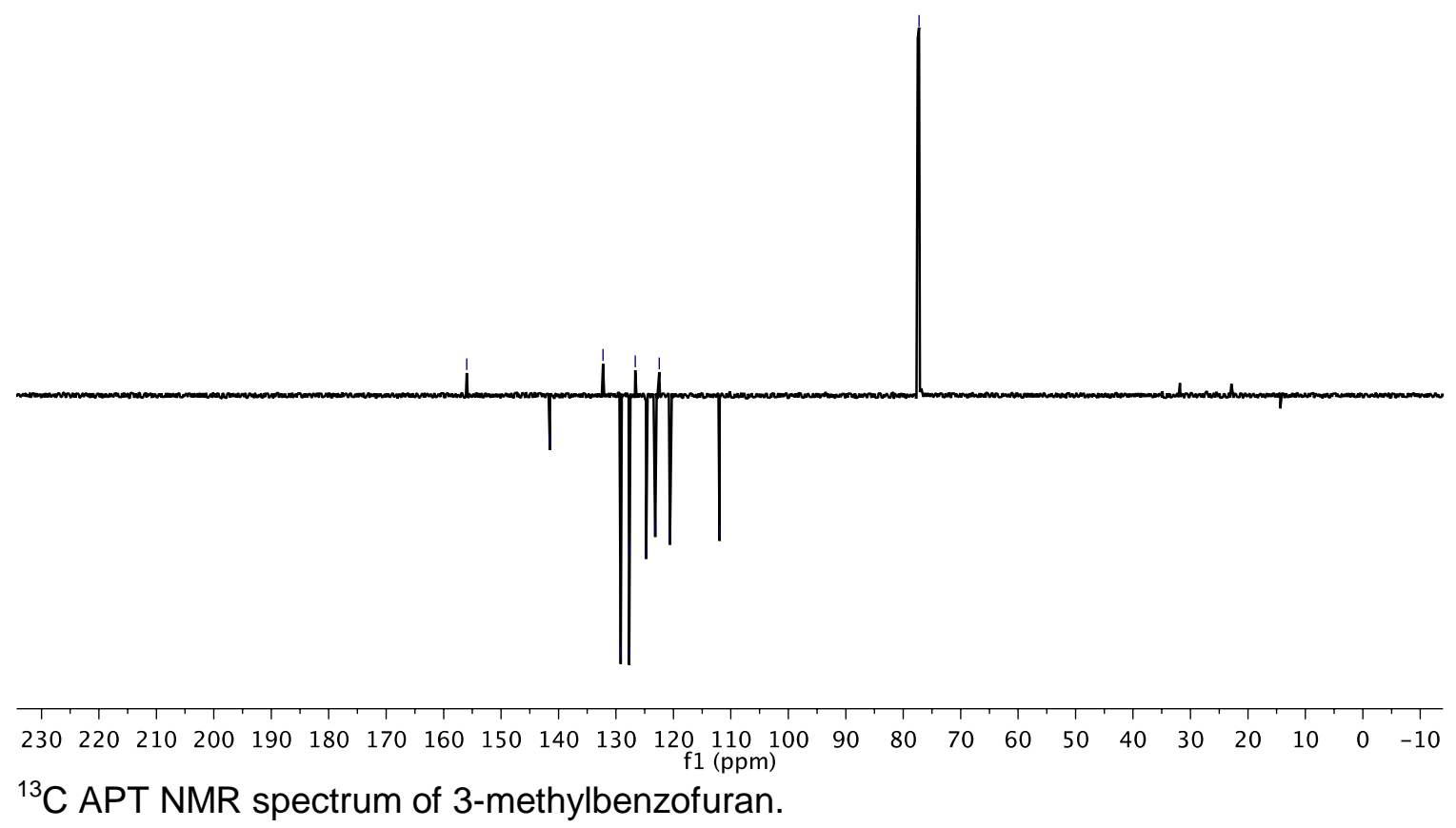




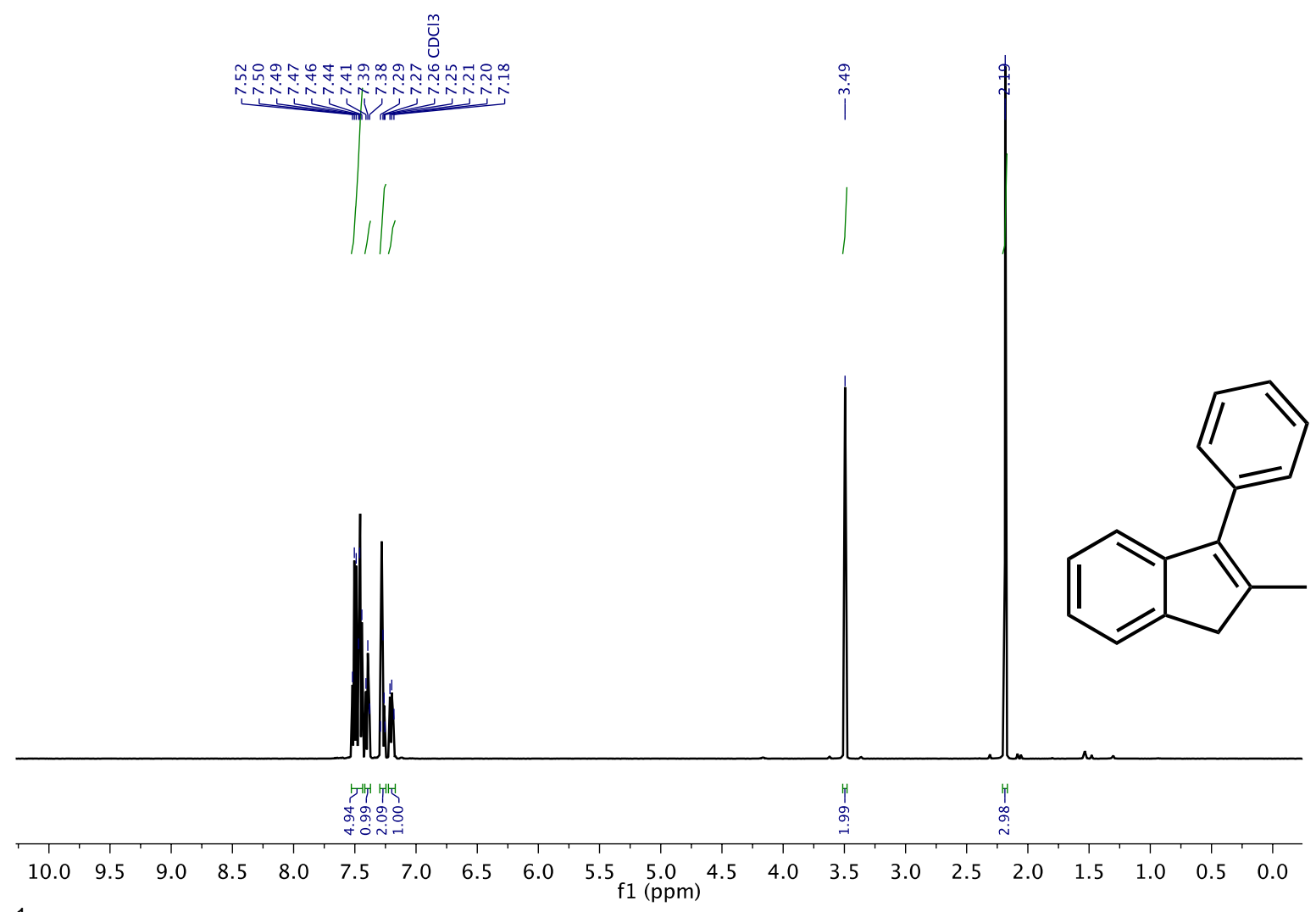

${ }^{1} \mathrm{H}$ NMR spectrum of 2-methyl-3-phenyl-1 $\mathrm{H}$-indene.

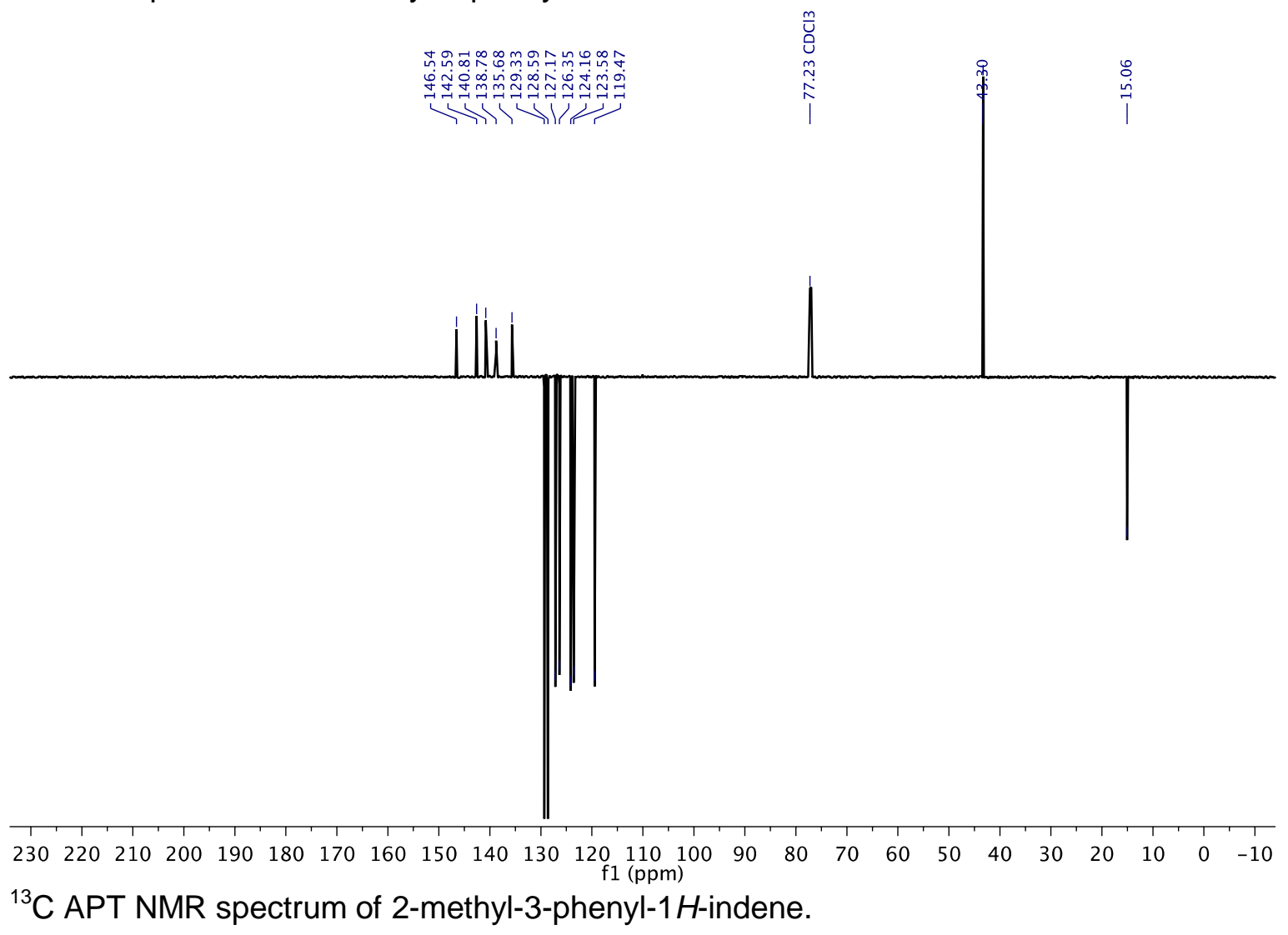




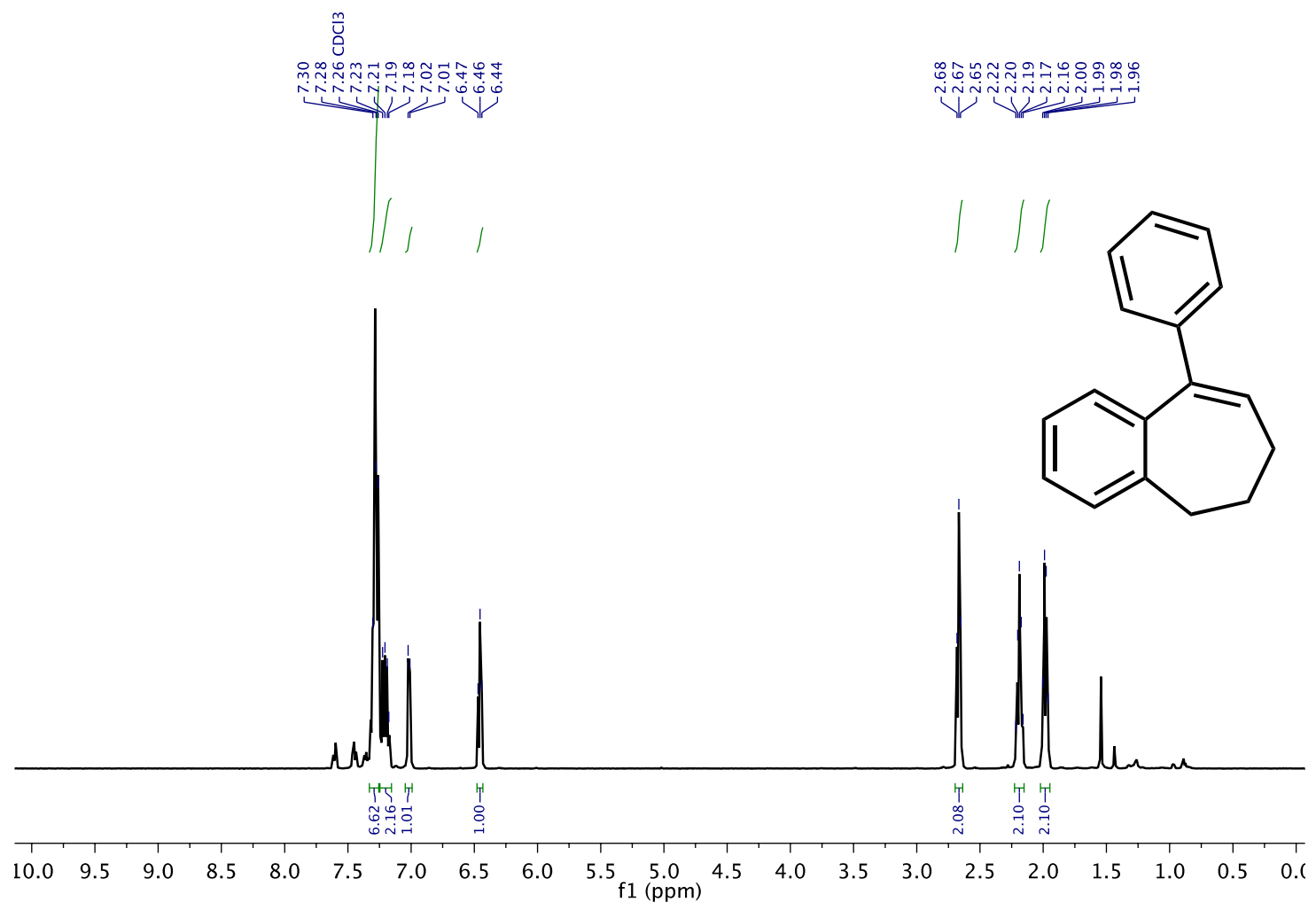

${ }^{1} \mathrm{H}$ NMR spectrum of 1-phenyl-benzosuberene.

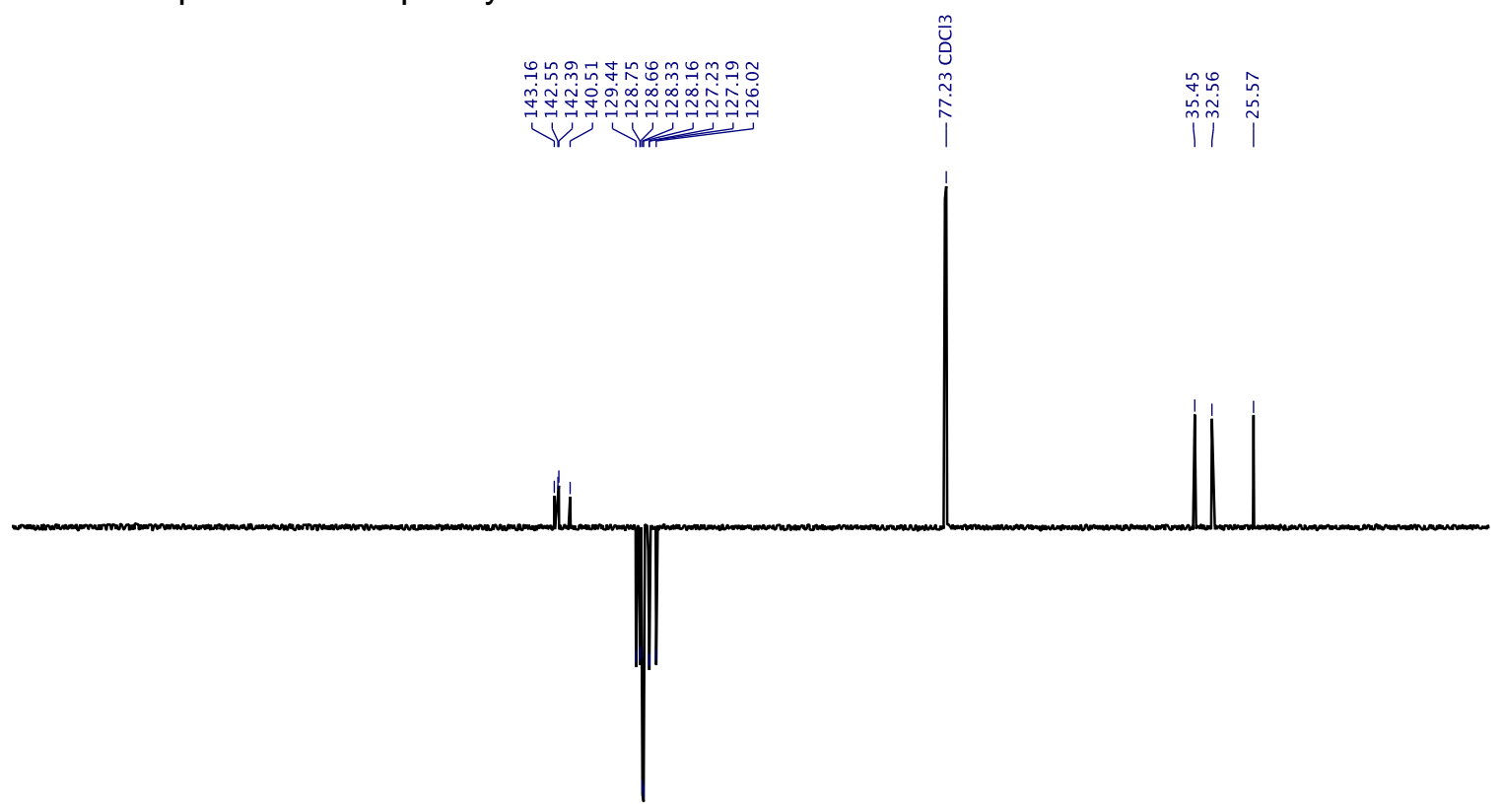

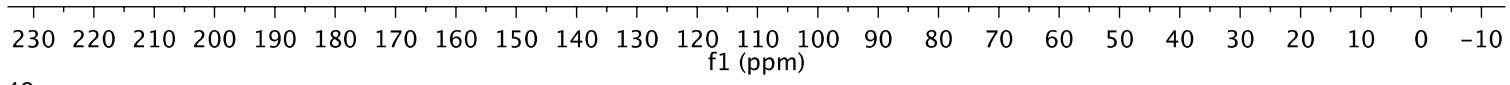
${ }^{13} \mathrm{C}$ APT NMR spectrum of 1-phenyl-benzosuberene. 


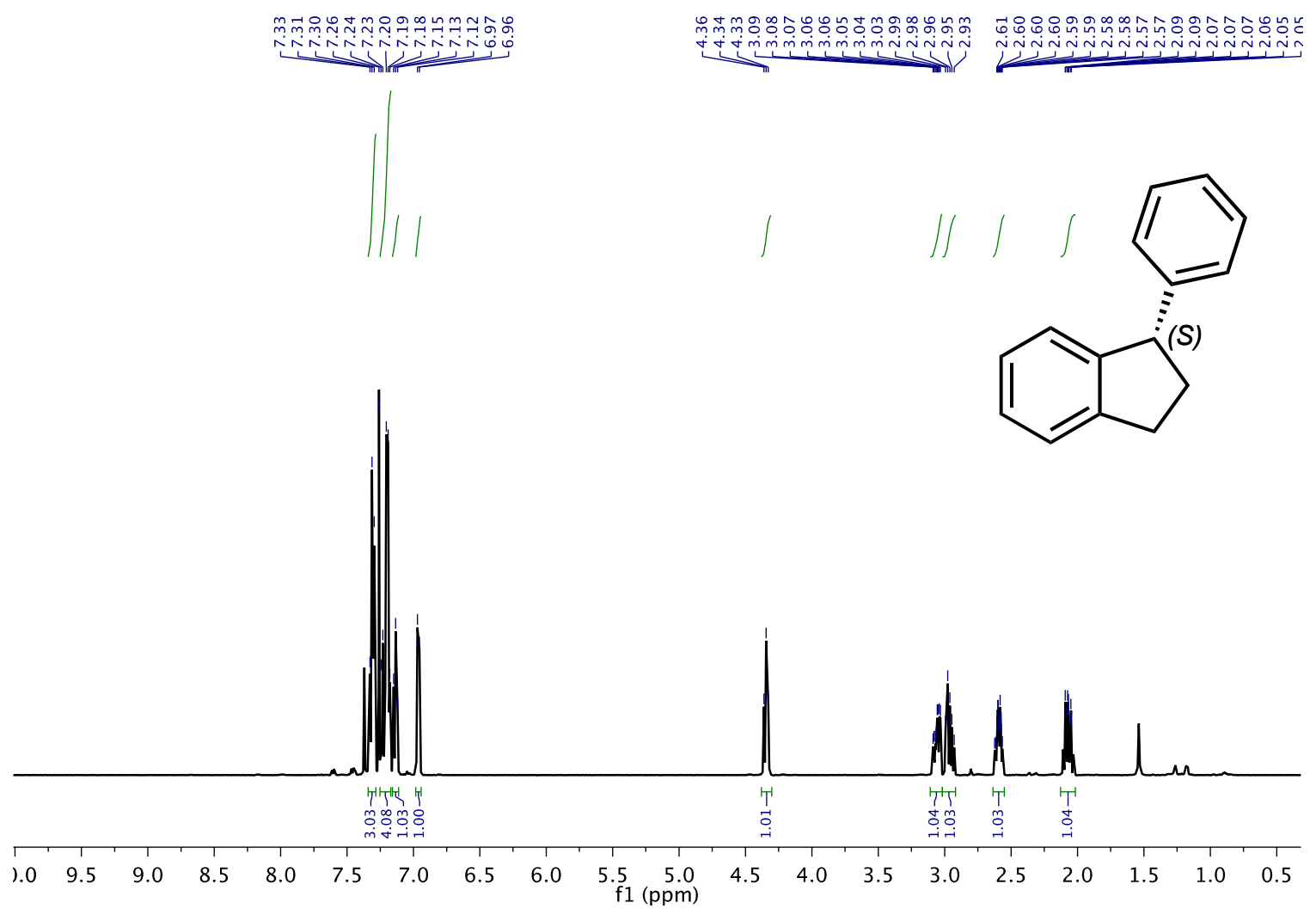

${ }^{1} \mathrm{H}$ NMR spectrum of (S)-(-)-1-phenyl-indane (2a).

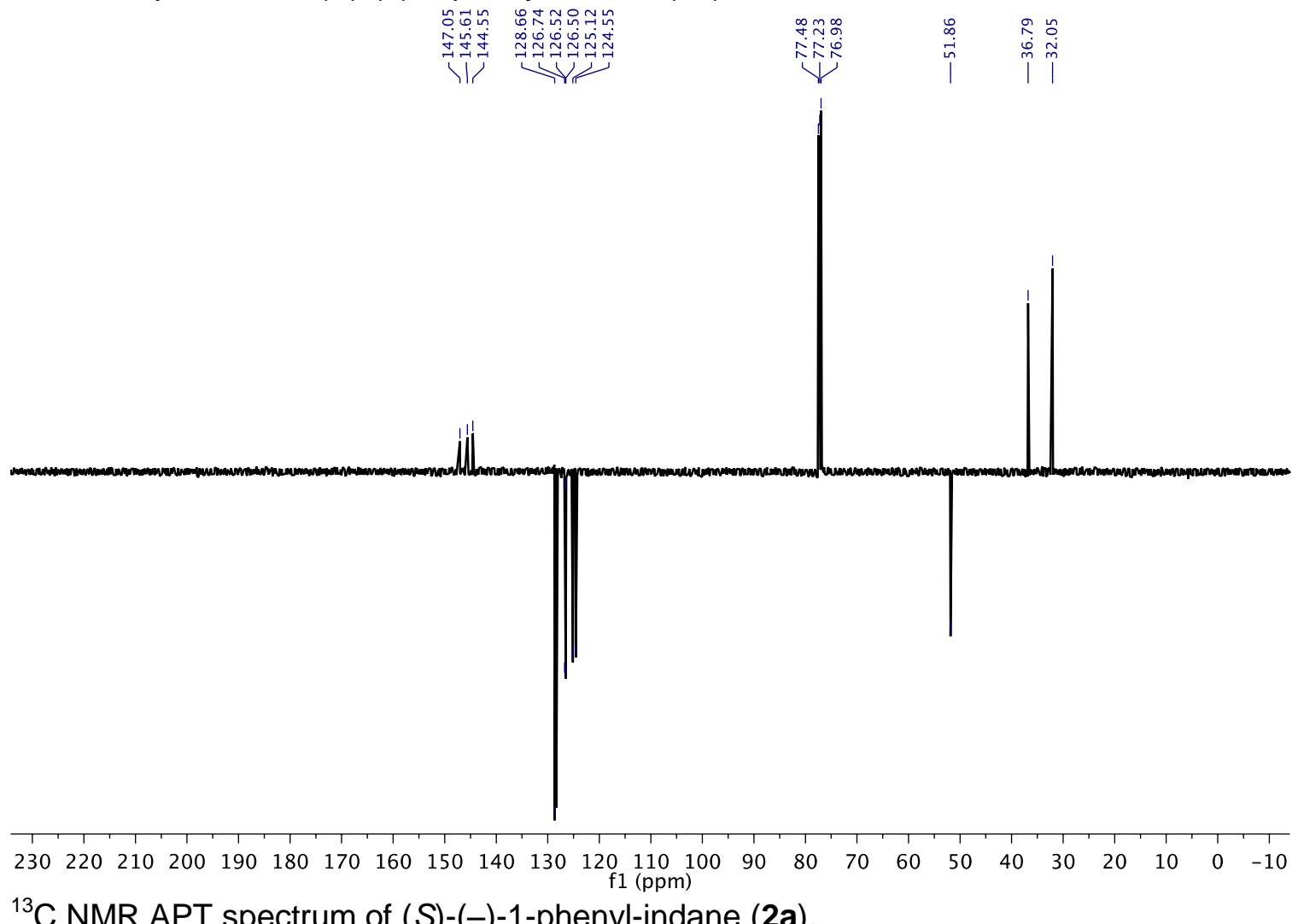

${ }^{13} \mathrm{C}$ NMR APT spectrum of $(S)-(-)-1$-phenyl-indane (2a). 


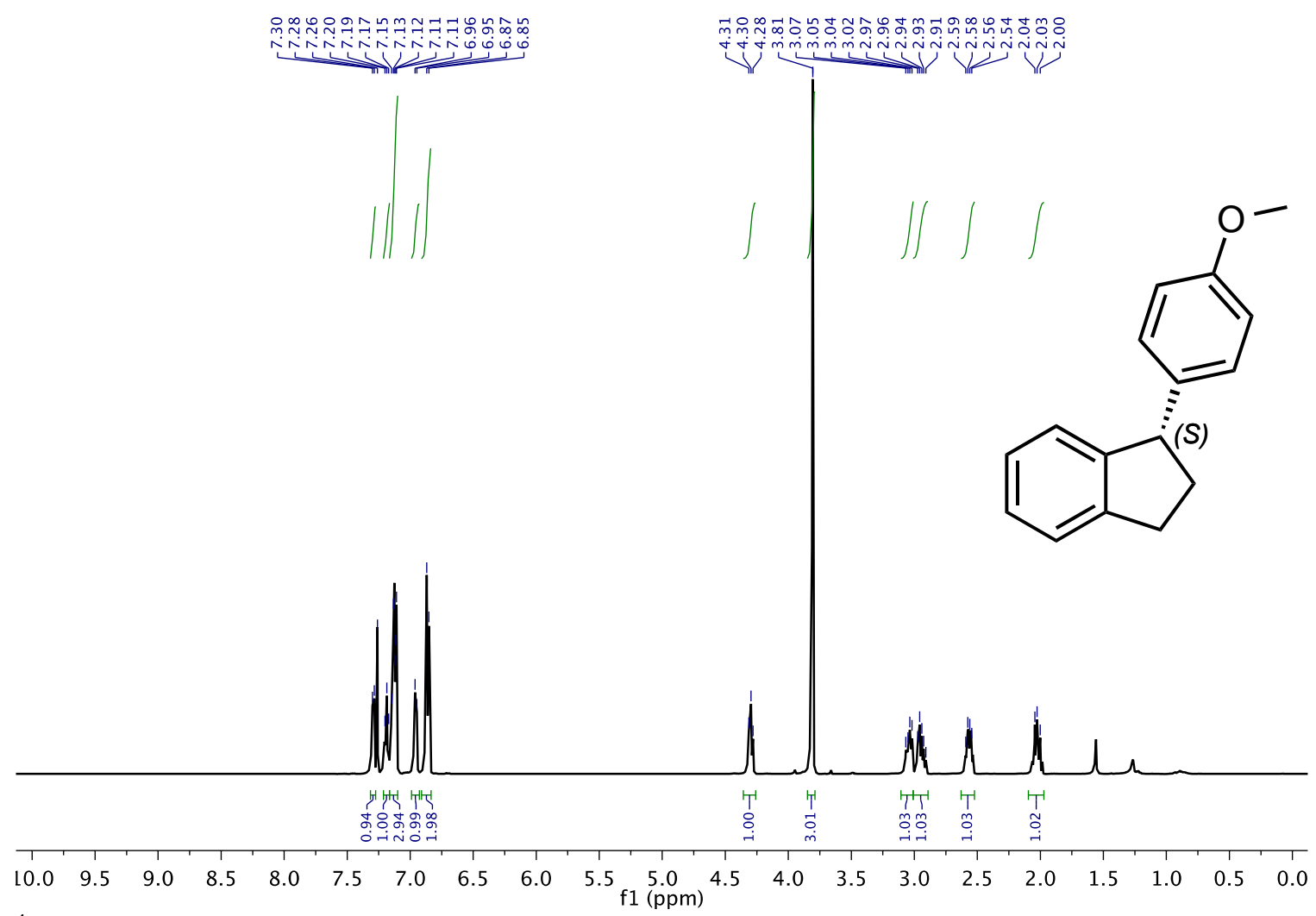

${ }^{1} \mathrm{H}$ NMR spectrum of $(S)-(-)-1$-(p-methoxyphenyl)-indane (2b).
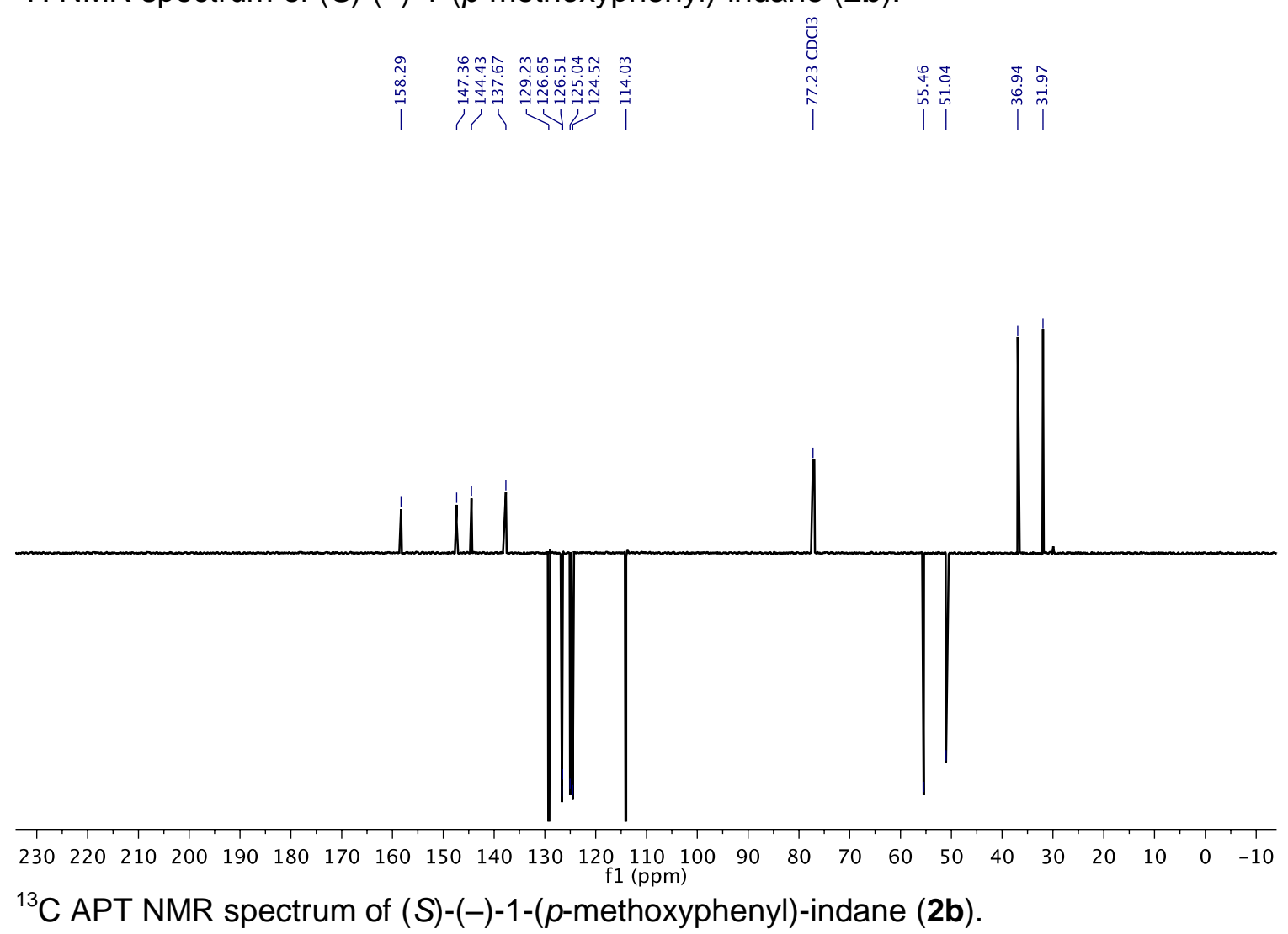


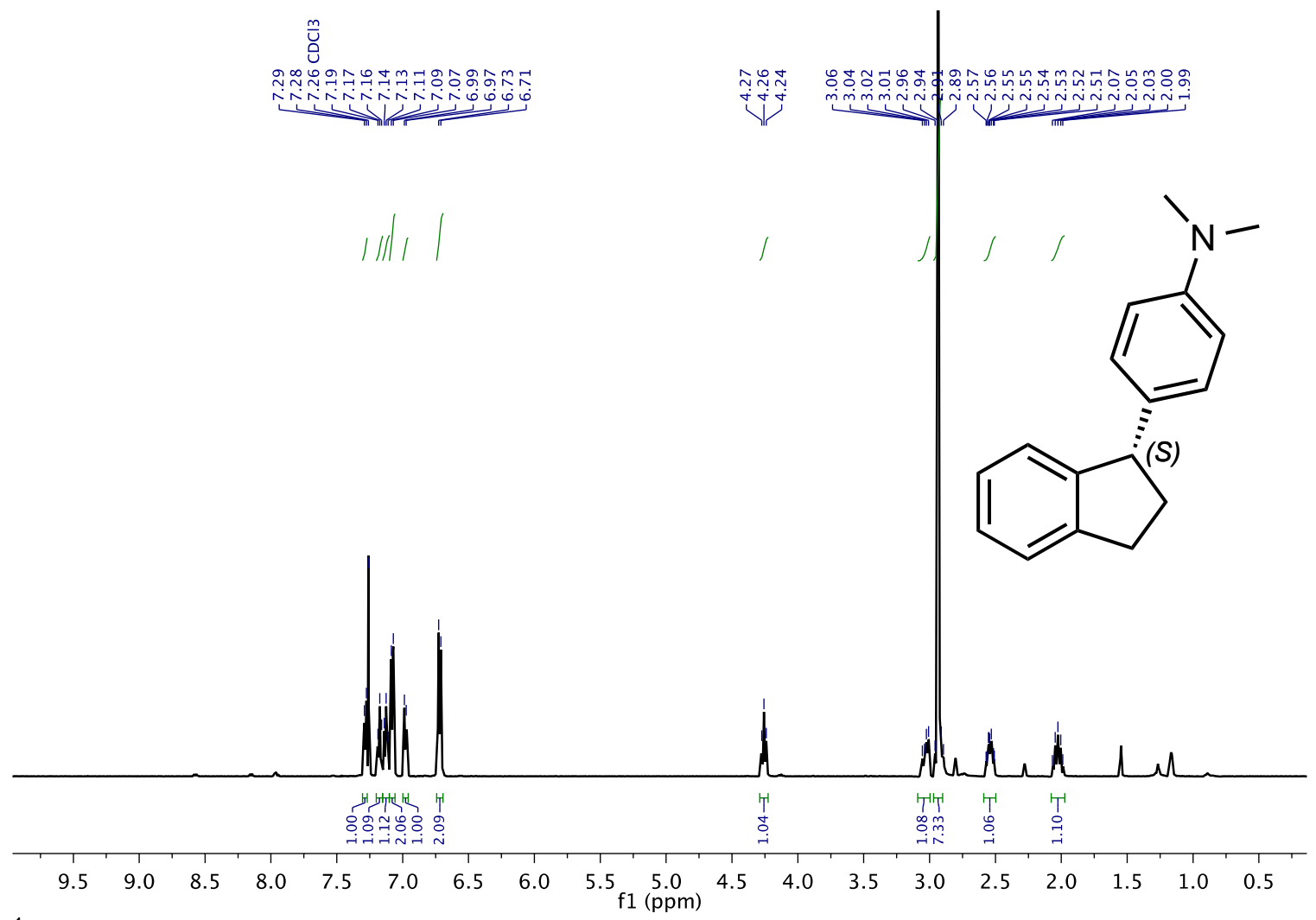

${ }^{1} \mathrm{H}$ NMR spectrum of $(S)-(-)-1-(p$-dimethylaminophenyl)-indane $(2 \mathbf{c})$.
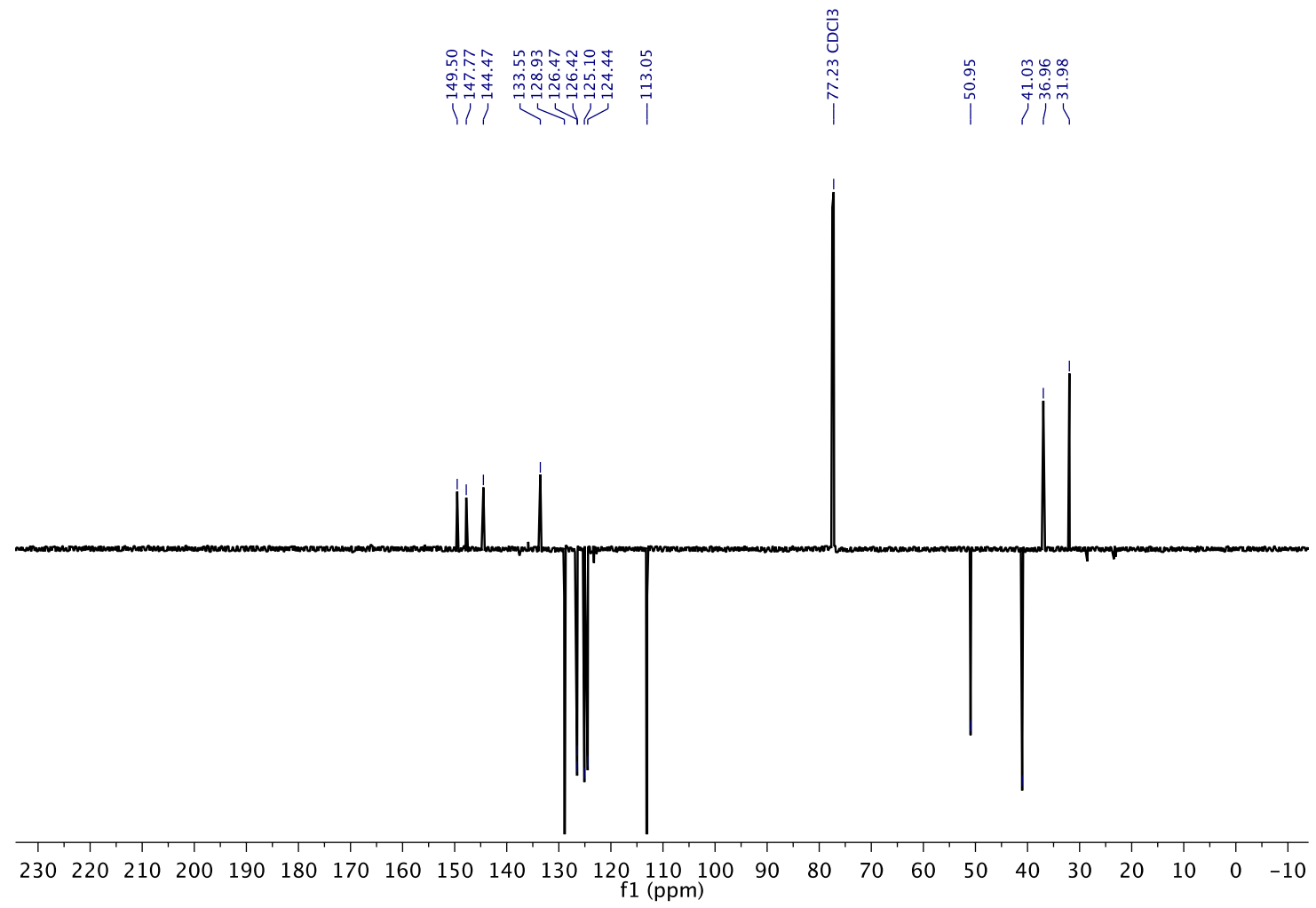

${ }^{13} \mathrm{C}$ APT NMR spectrum of $(S)-(-)-1$-(p-dimethylaminophenyl)-indane (2c). 


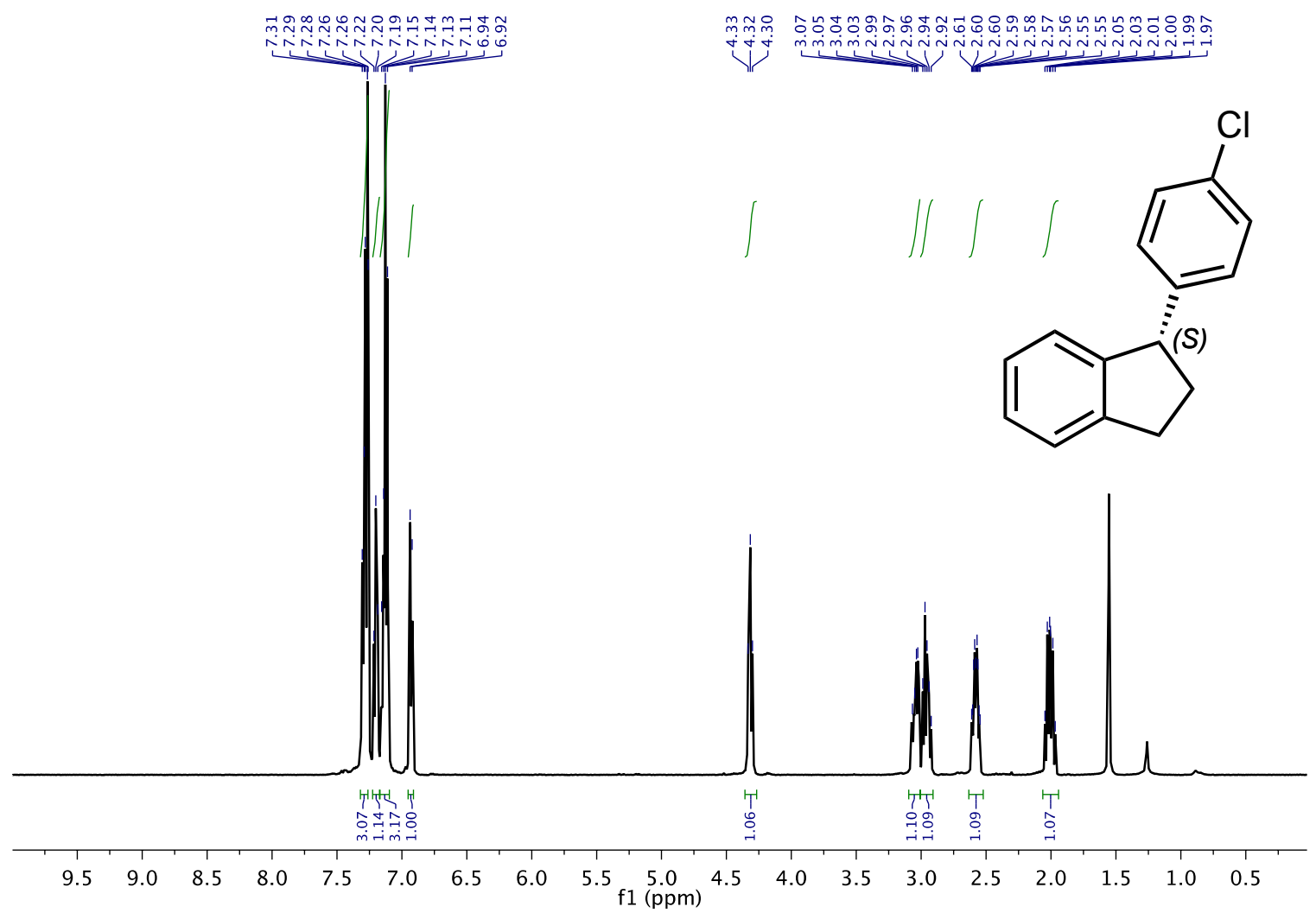

${ }^{1} \mathrm{H}$ NMR spectrum of $(S)-(-)-1-(p$-chlorophenyl)-indane $(\mathbf{2 d})$.

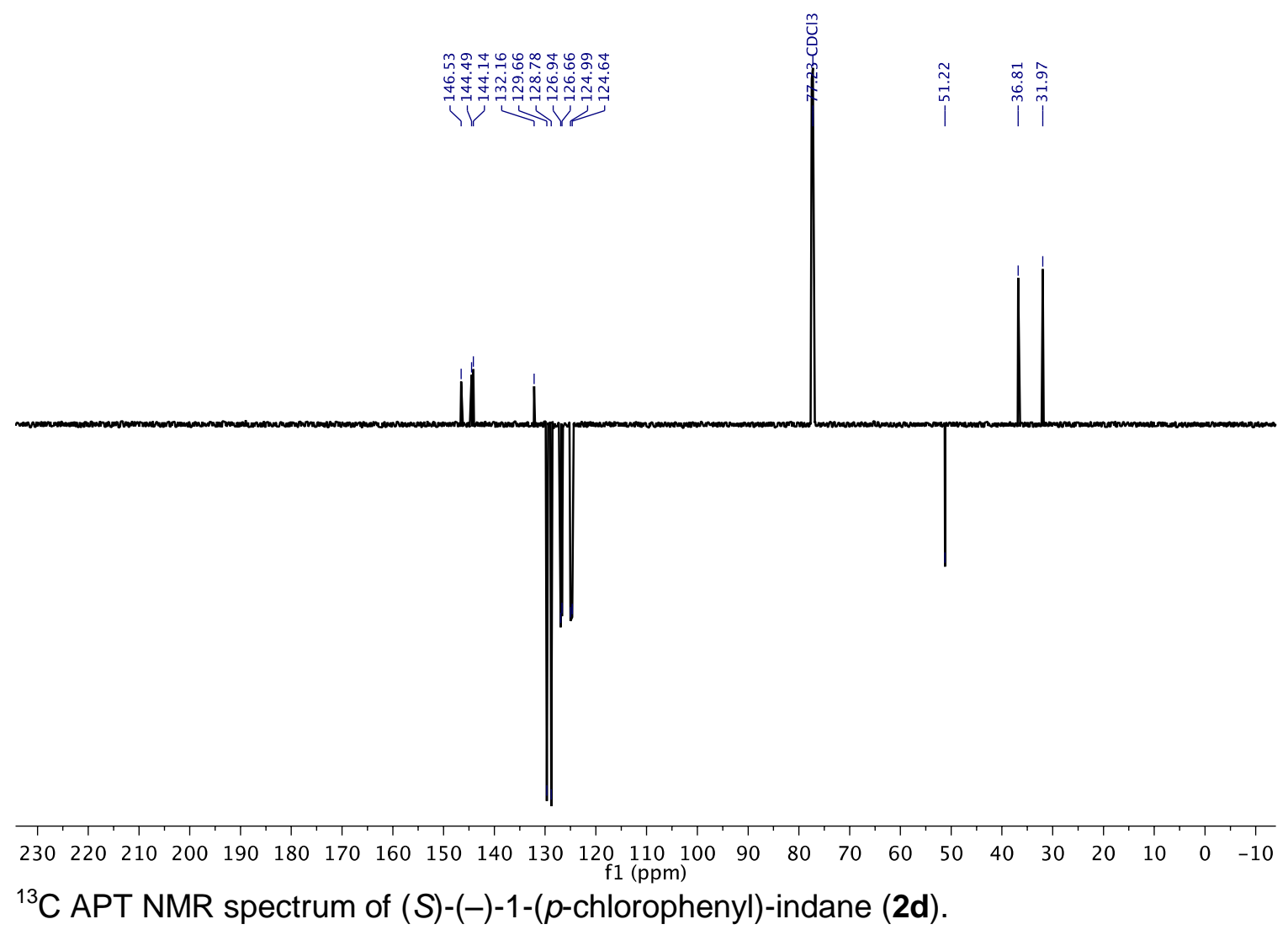




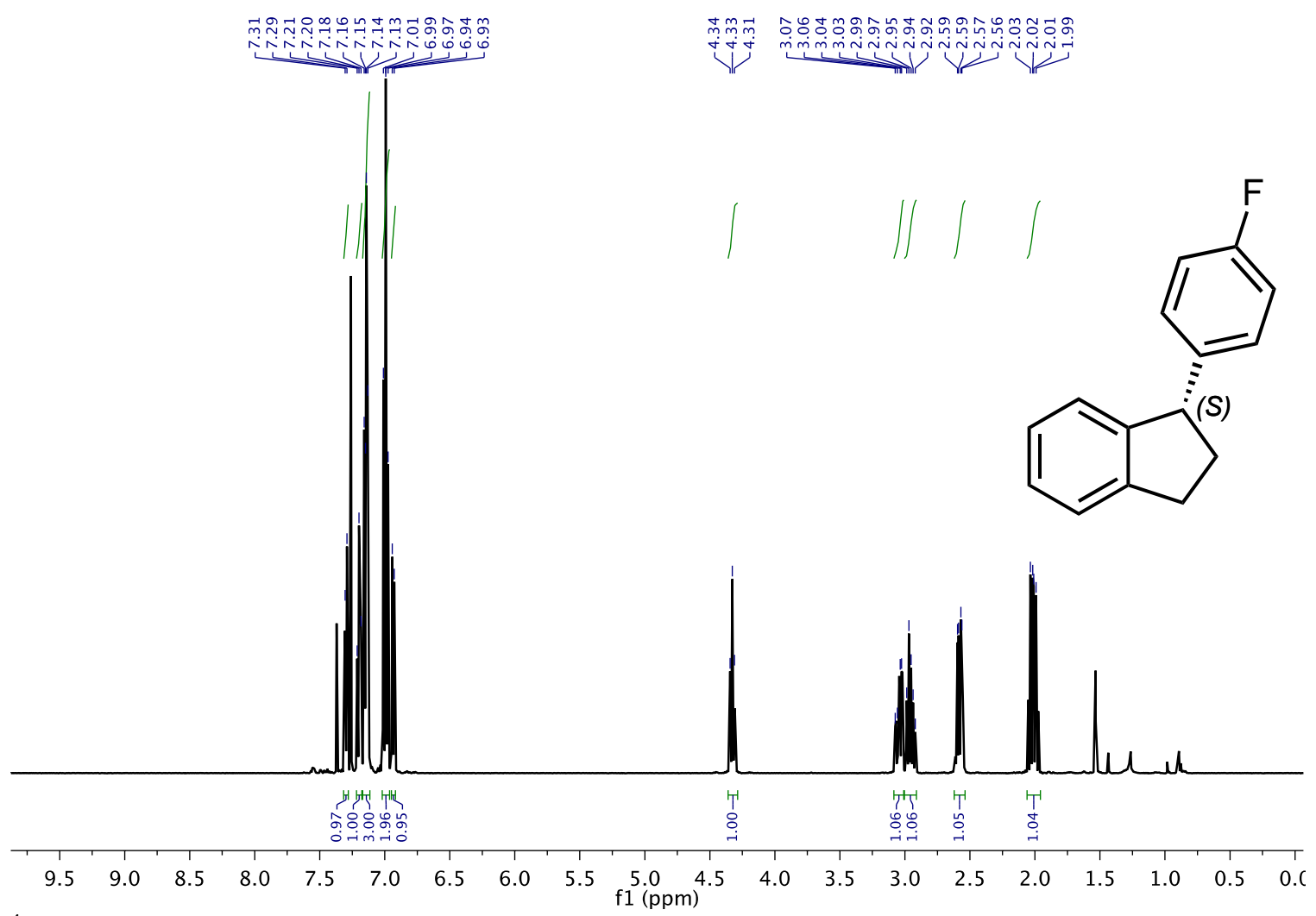

${ }^{1} \mathrm{H}$ NMR spectrum of (S)-(-)-1-(p-fluorophenyl)-indane (2e).

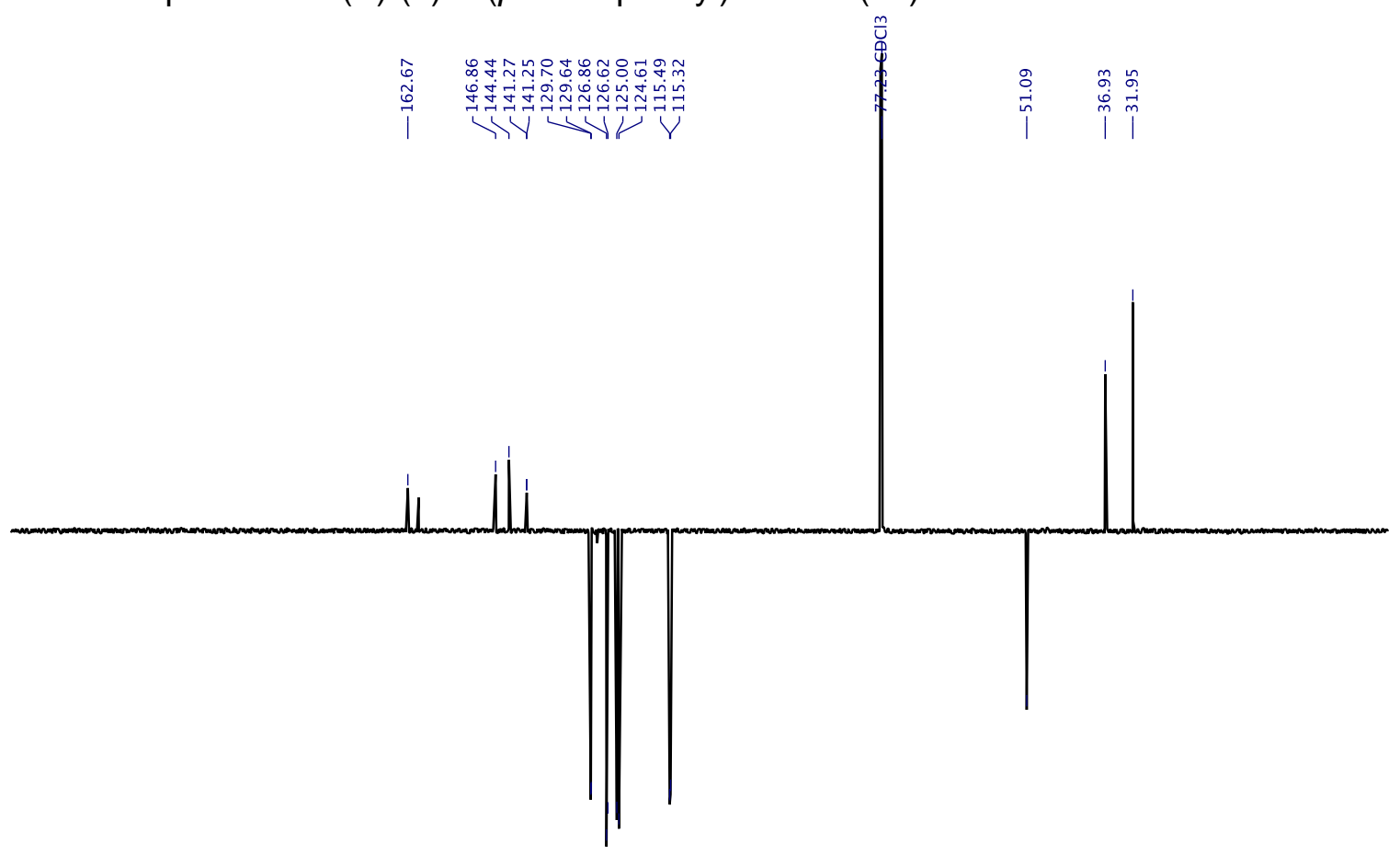

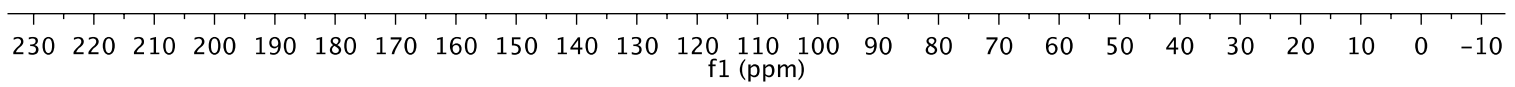
${ }^{13} \mathrm{C}$ APT NMR spectrum of (S)-(-)-1-(p-fluorophenyl)-indane (2e). 


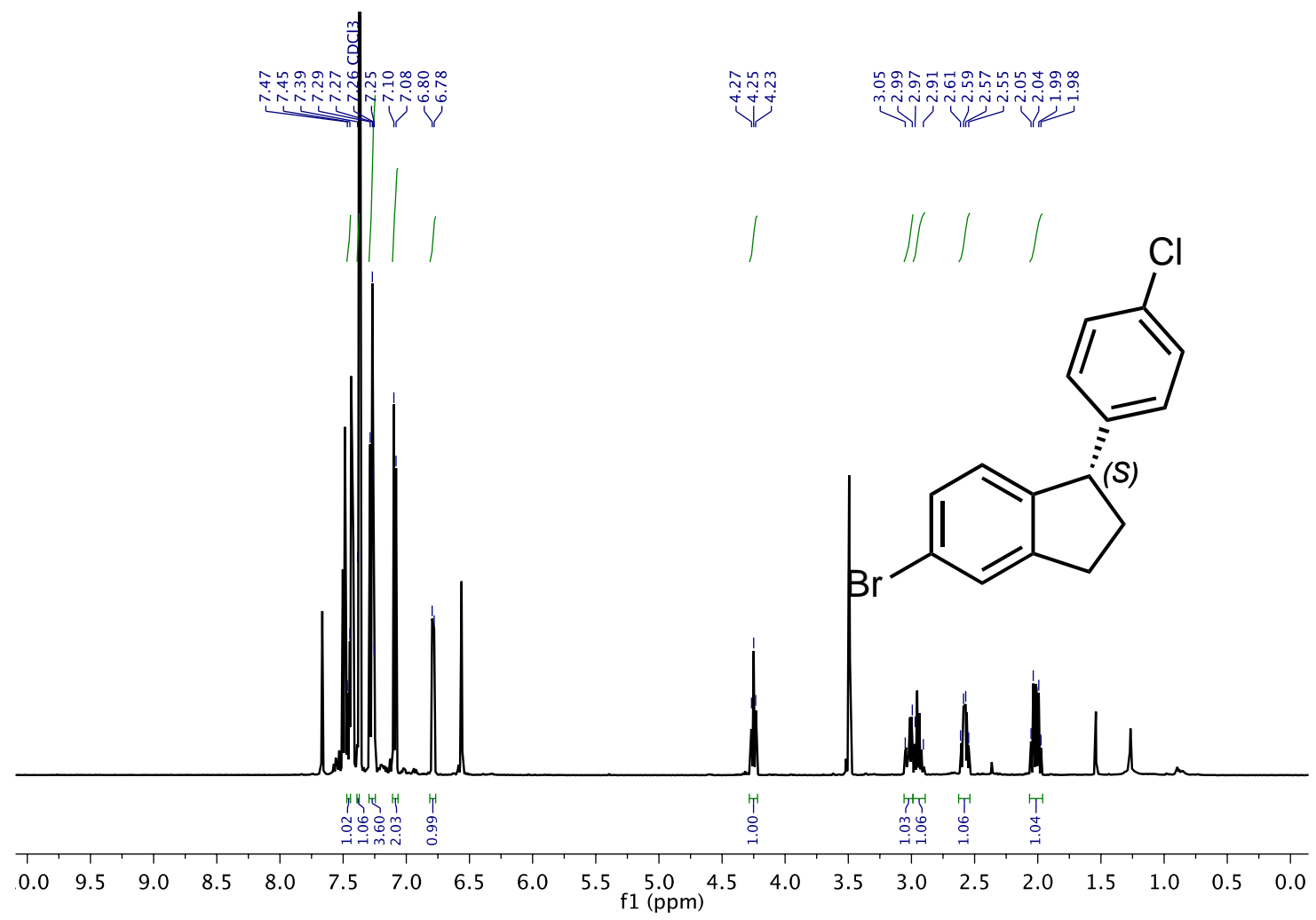

${ }^{1} \mathrm{H}$ NMR spectrum of (S)-(-)-1-(p-chlorophenyl)-6-bromo-indane (2f) containing $\mathbf{1 f}$ alkene.

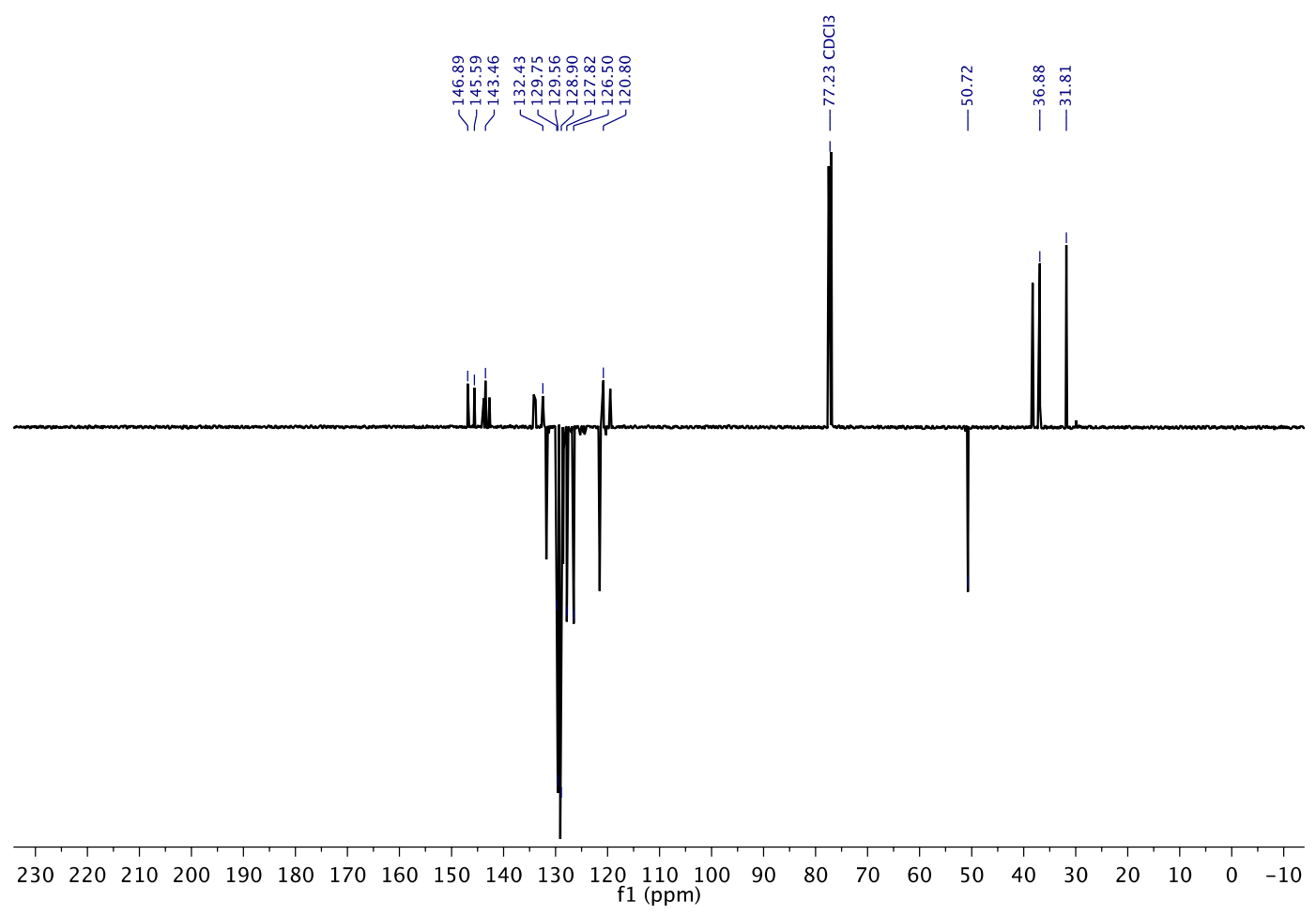

${ }^{13} \mathrm{C}$ APT NMR spectrum of $(S)-(-)-1-(p$-chlorophenyl)-6-bromo-indane (2f) containing $\mathbf{1 f}$ alkene. 

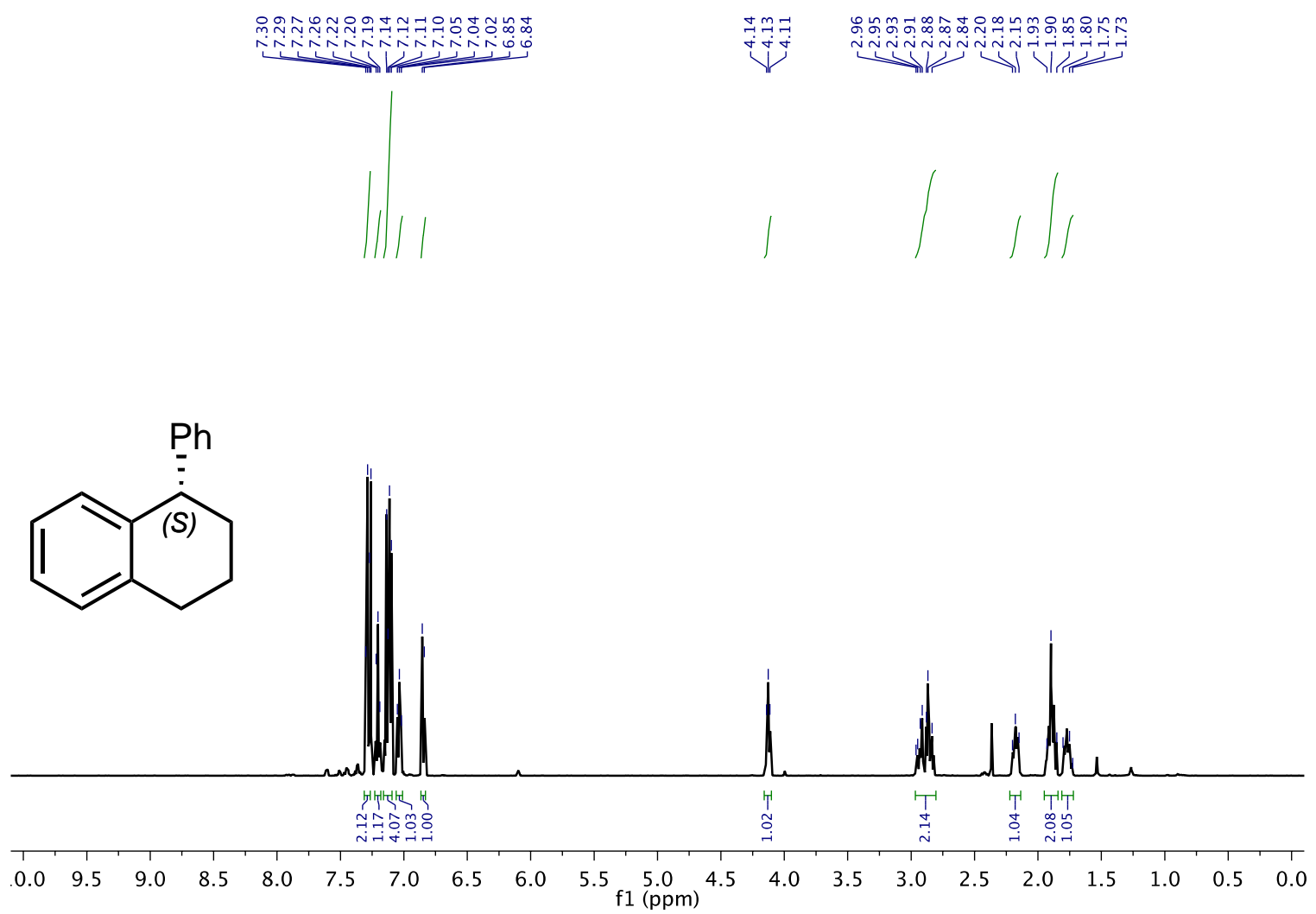

${ }^{1} \mathrm{H}$ NMR spectrum of $(S)-(+)-1$-phenyltetralin (4a).
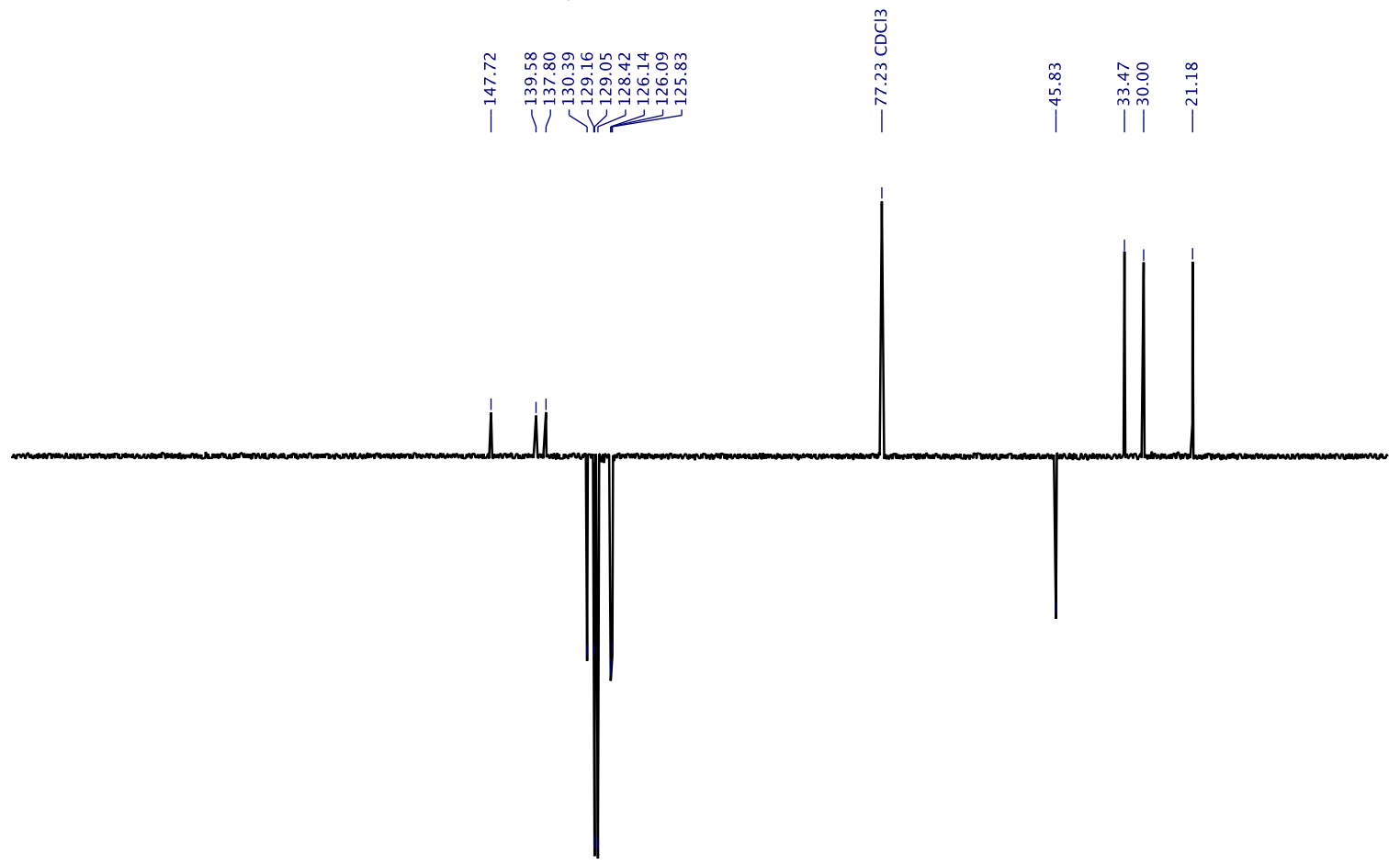

$\begin{array}{rlllllllllllllllllllllllllllllllll}230 & 220 & 210 & 200 & 190 & 180 & 170 & 160 & 150 & 140 & 130 & 120 & 110 & 100 & 90 & 80 & 70 & 60 & 50 & 40 & 30 & 20 & 10 & 0 & -10\end{array}$

${ }^{13} \mathrm{C}$ NMR spectrum of $(S)-(+)-1$-phenyltetralin (4a). 


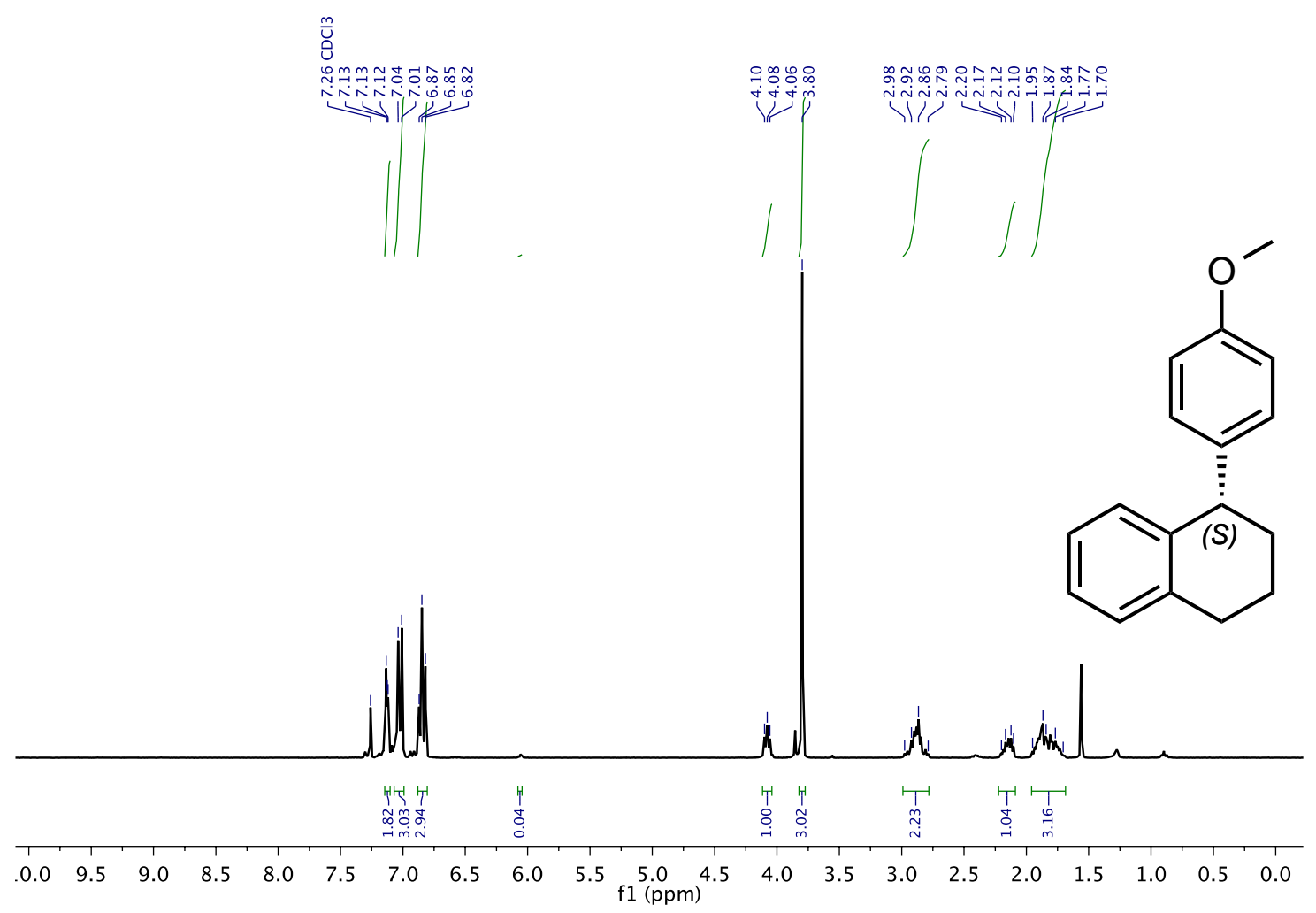

${ }^{1} \mathrm{H}$ NMR spectrum of $(S)-(+)-1-(p$-methoxyphenyl)-tetralin (4b).
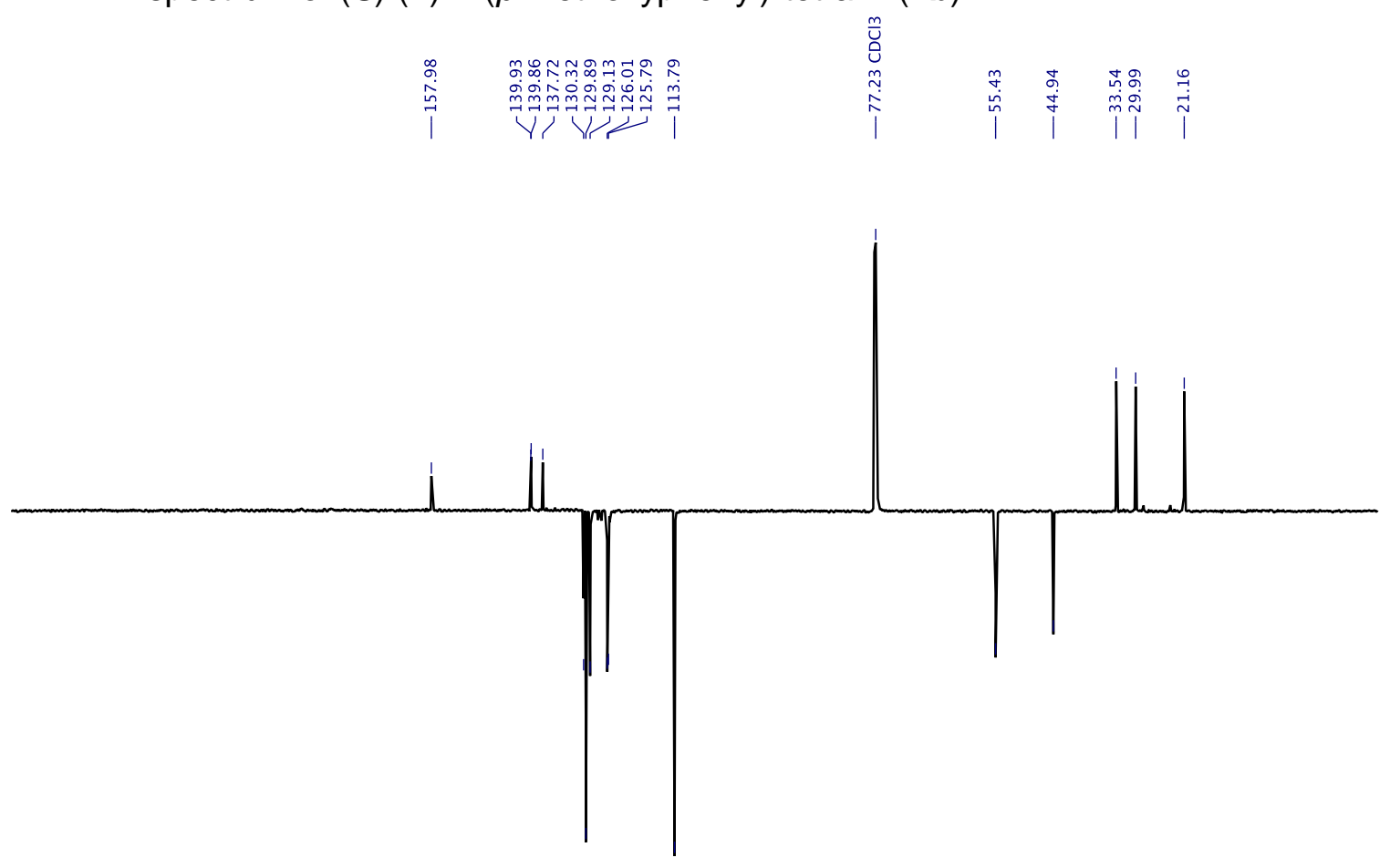

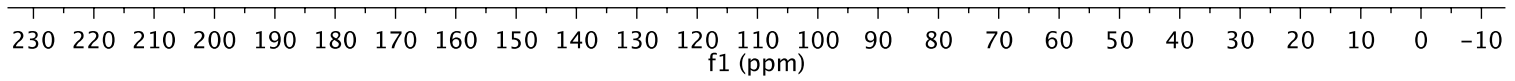
${ }^{13} \mathrm{C}$ NMR spectrum of $(S)-(+)-1-(p$-methoxyphenyl)-tetralin (4b). 


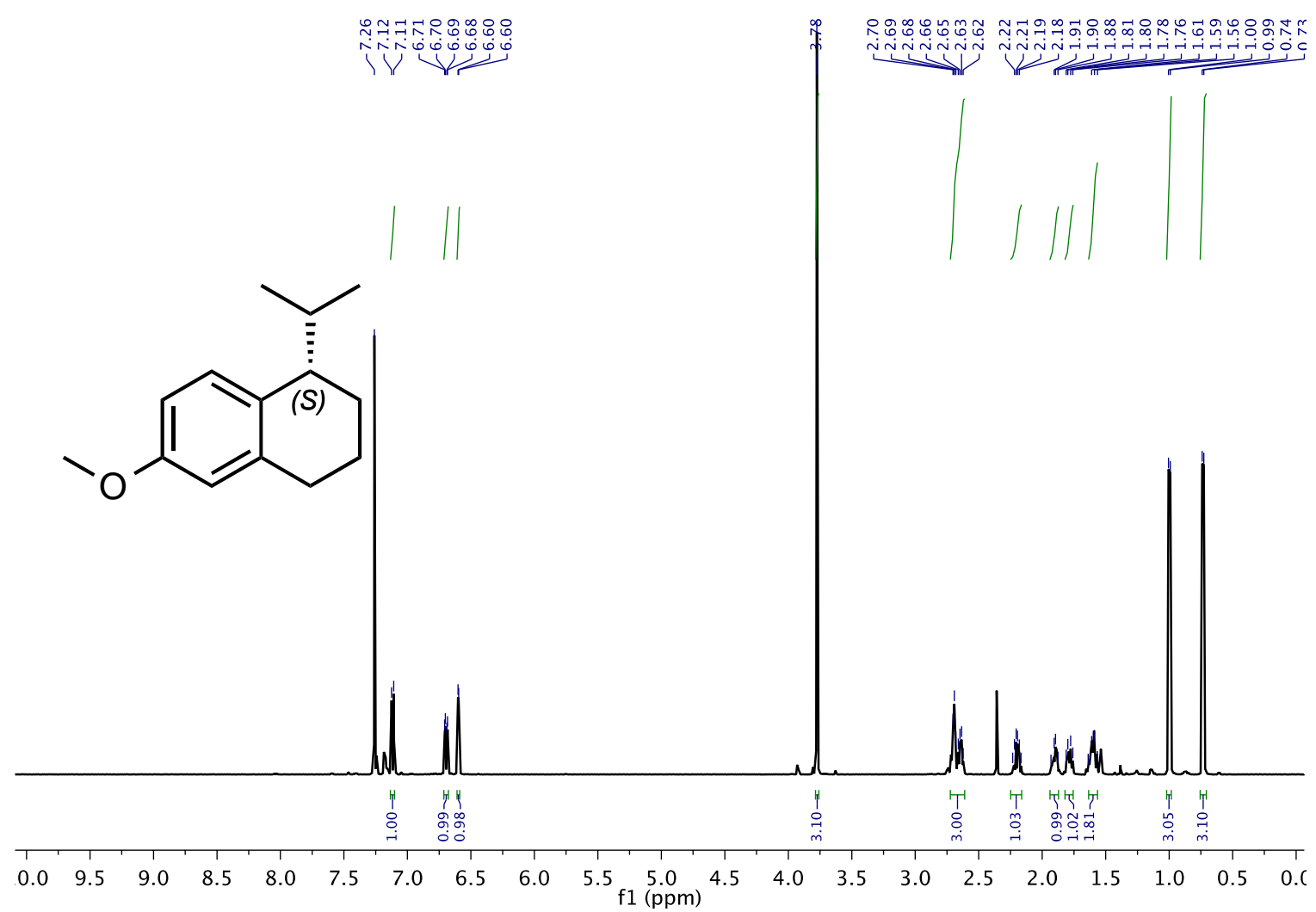

${ }^{1} \mathrm{H}$ NMR spectrum of $(S)-(-)$-1-isopropyl-6-methoxytetralin (6a).
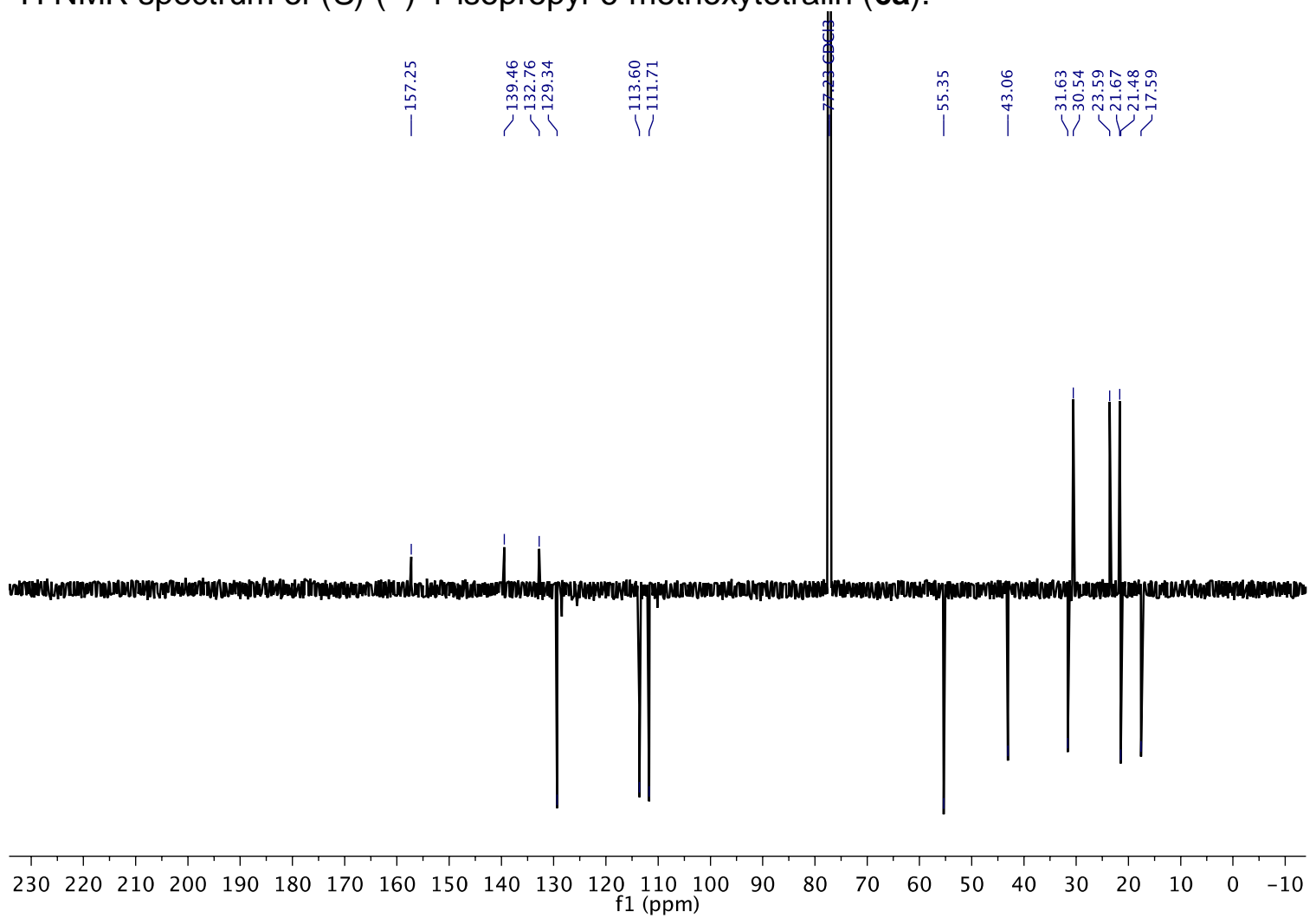

${ }^{1} \mathrm{H}$ NMR spectrum of (S)-(-)-1-isopropyl-6-methoxytetralin (6a). 


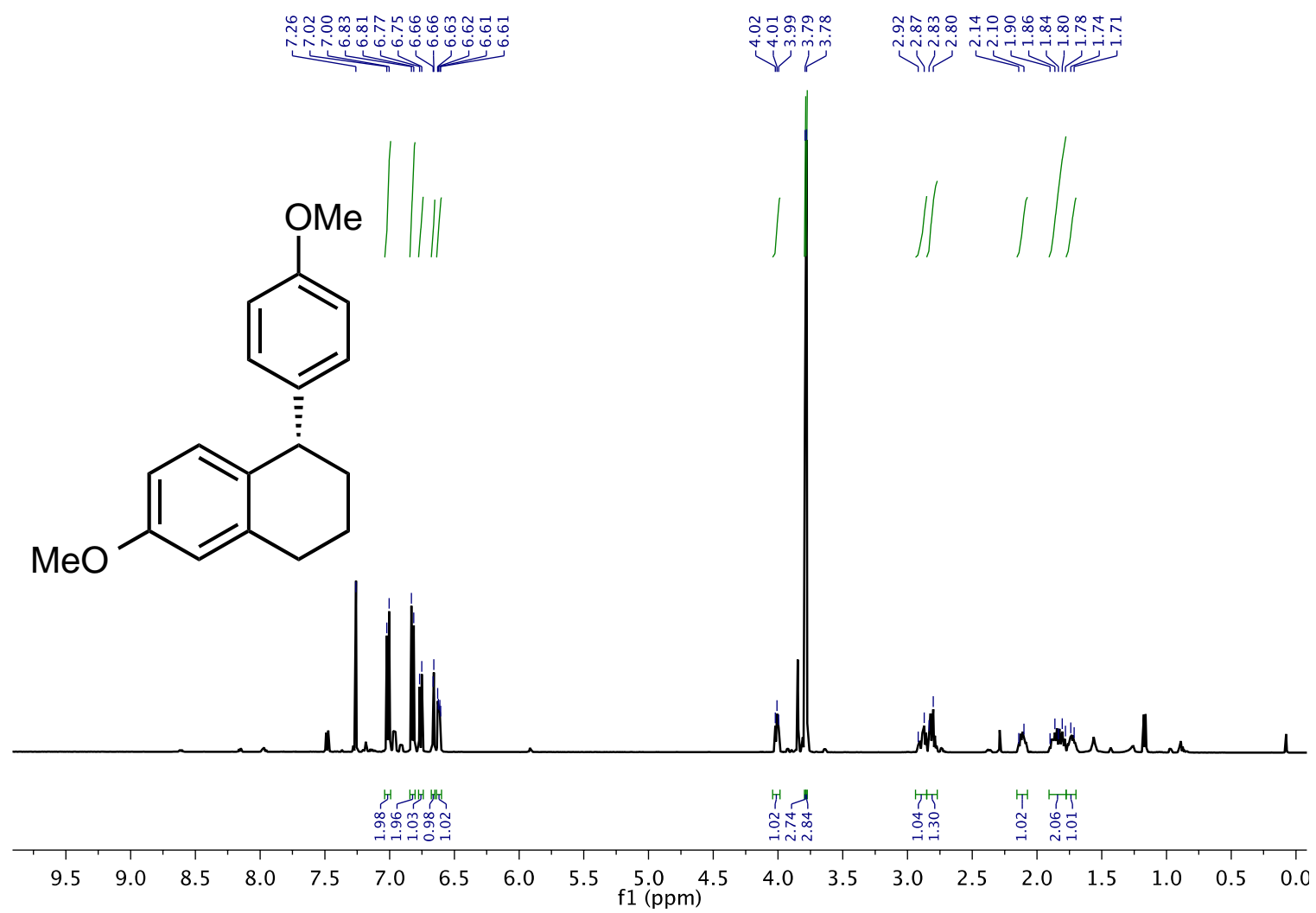

${ }^{1} \mathrm{H}$ NMR spectrum of (S)-(+)-1-(4-methoxyphenyl)-6-methoxytetralin (6b).

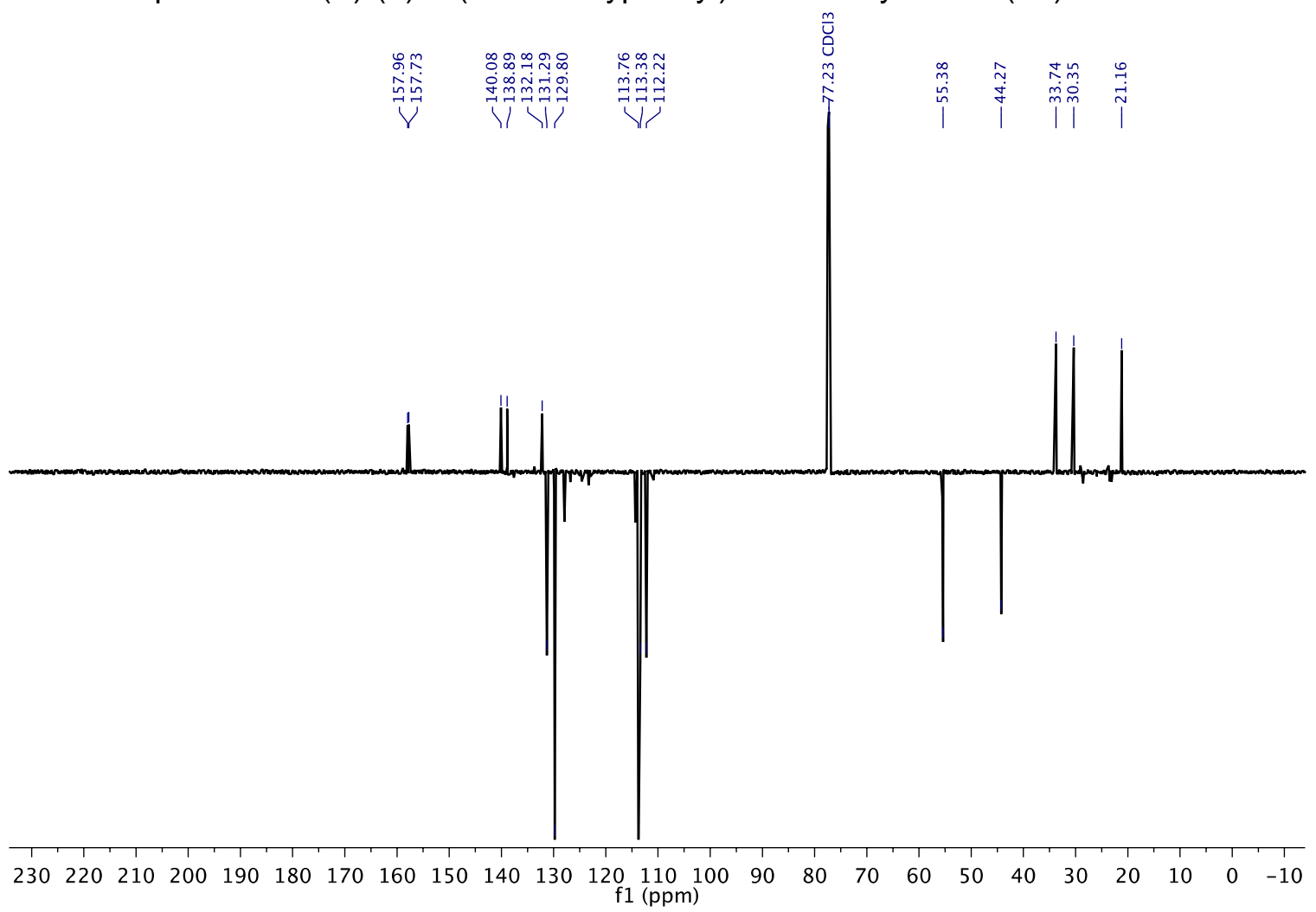

${ }^{13} \mathrm{C}$ APT NMR spectrum of $(S)-(+)-1-(4-m e t h o x y p h e n y l)-6-m e t h o x y t e t r a l i n(6 \mathbf{b})$. 


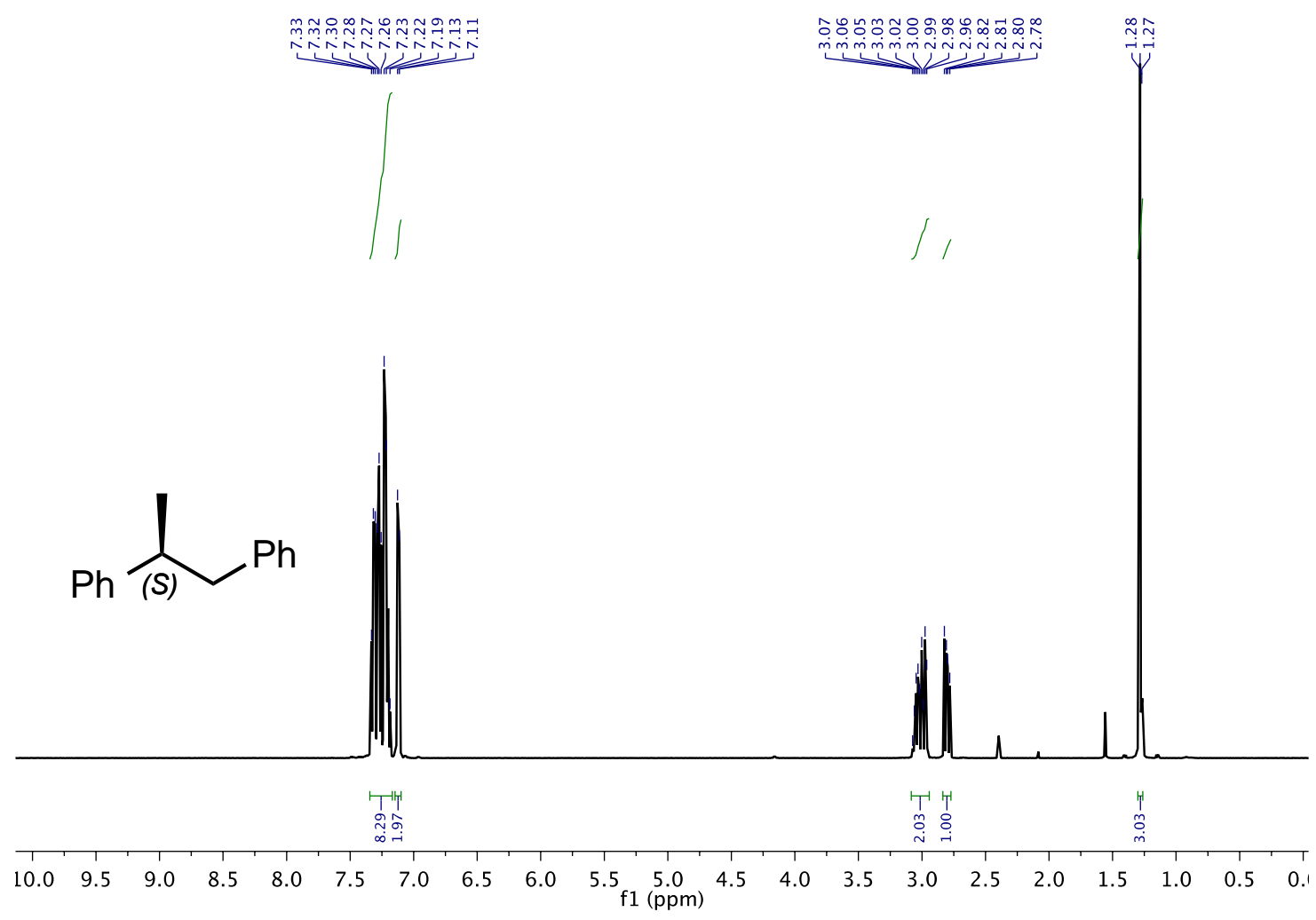

${ }^{1} \mathrm{H}$ NMR spectrum of (S)-(+)-1,2-diphenylpropane (8).

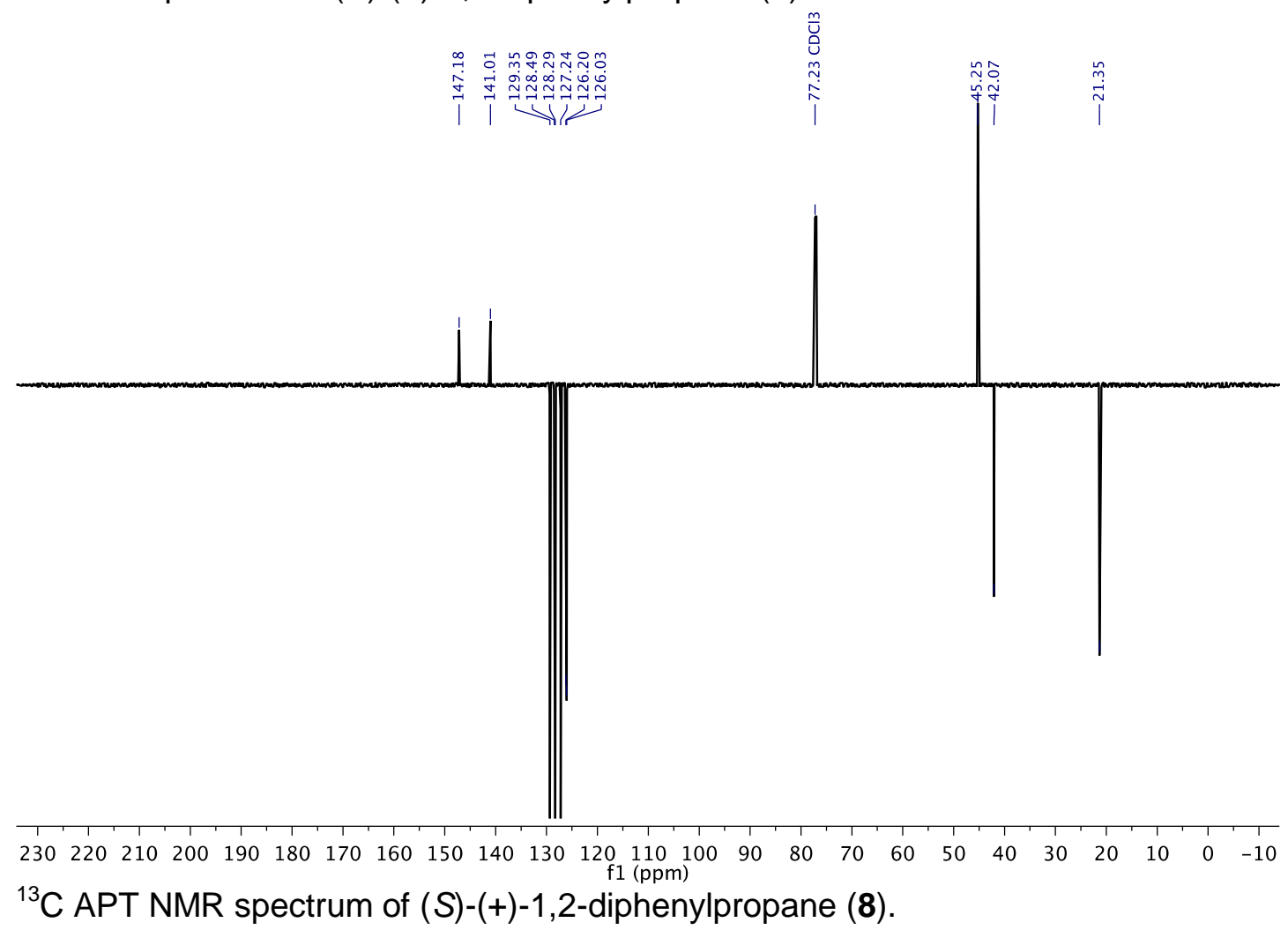




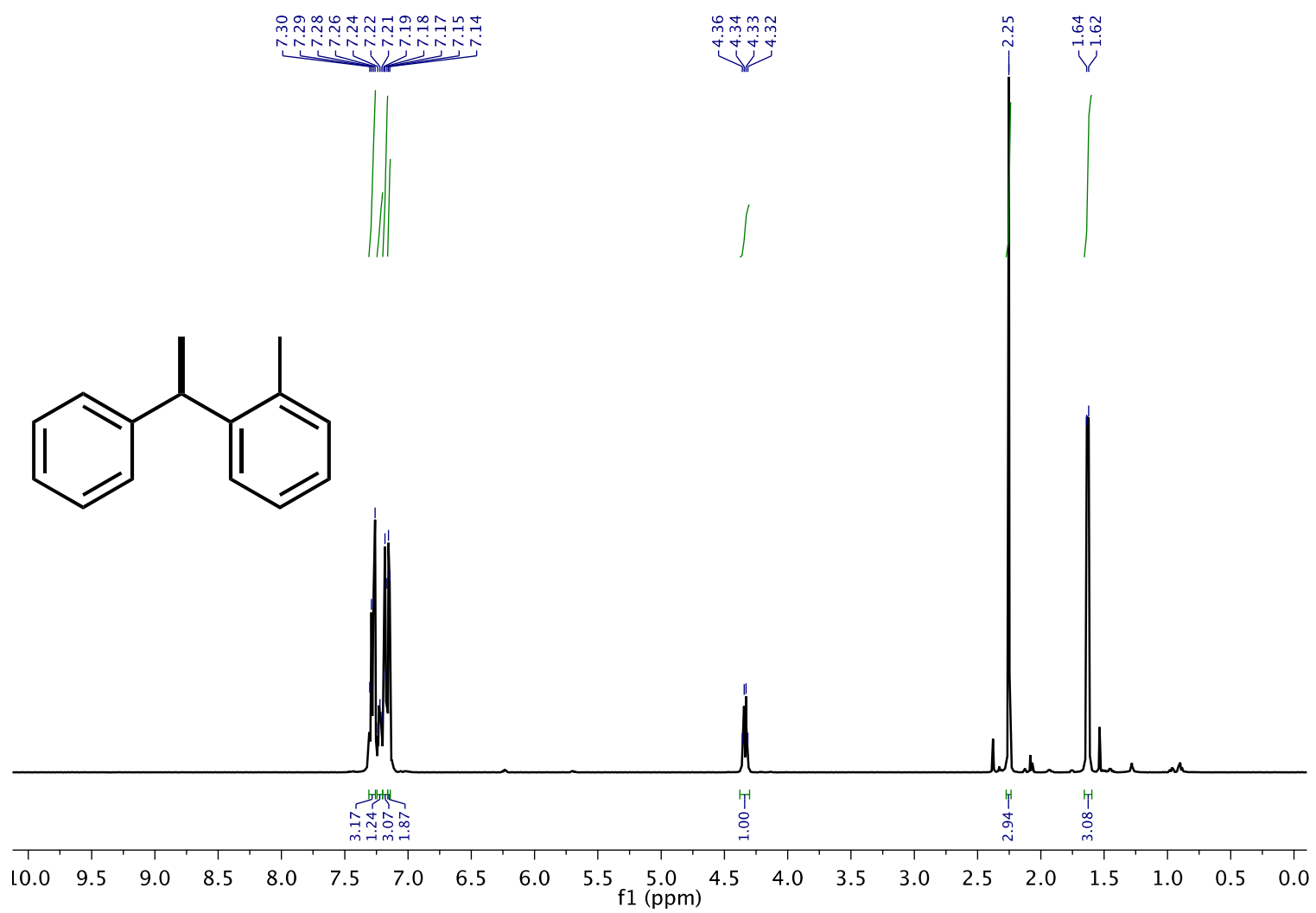

${ }^{1} \mathrm{H}$ NMR spectrum of (-)-1-phenyl-1-(o-tolyl)-ethane (10a).

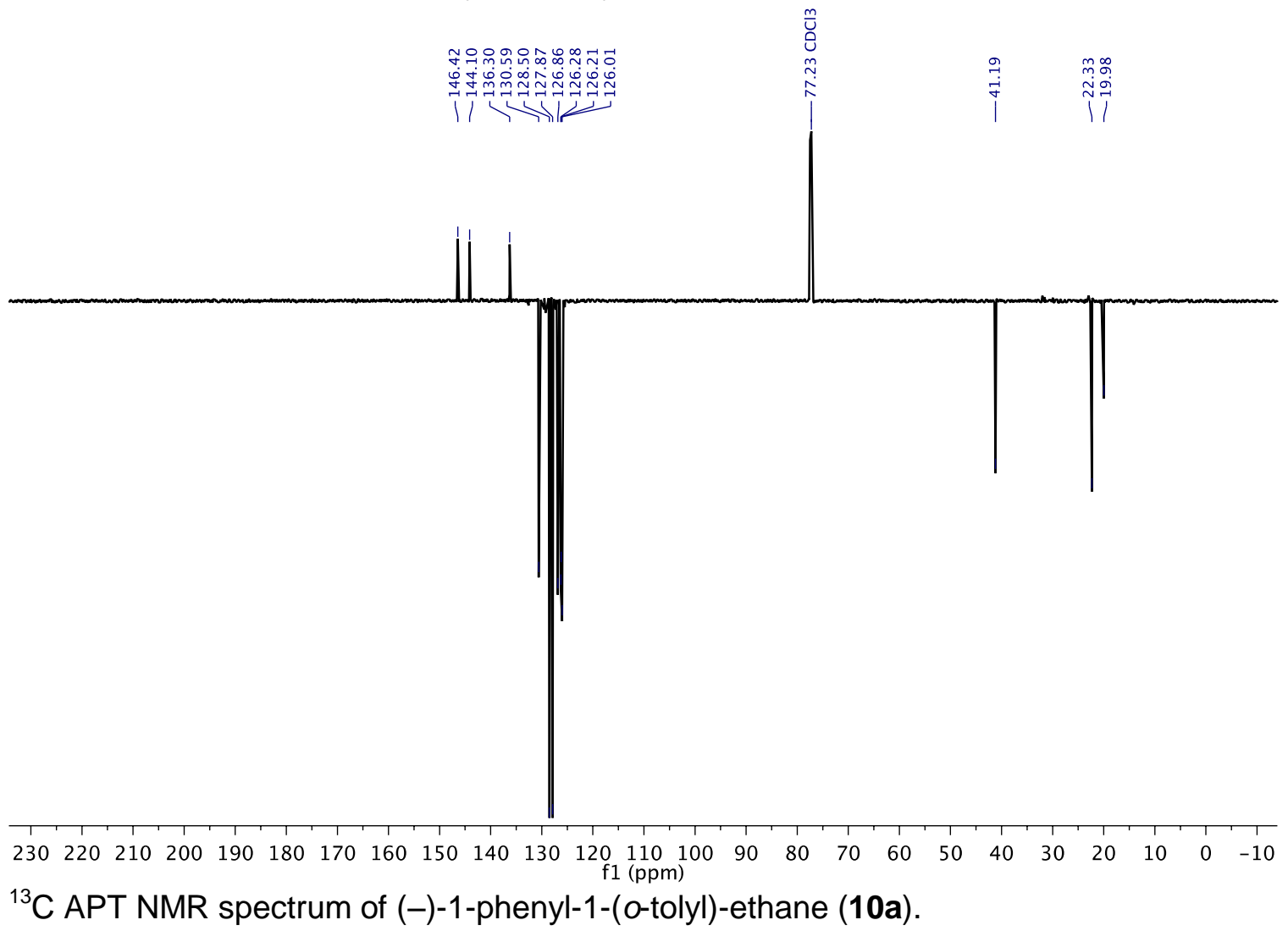




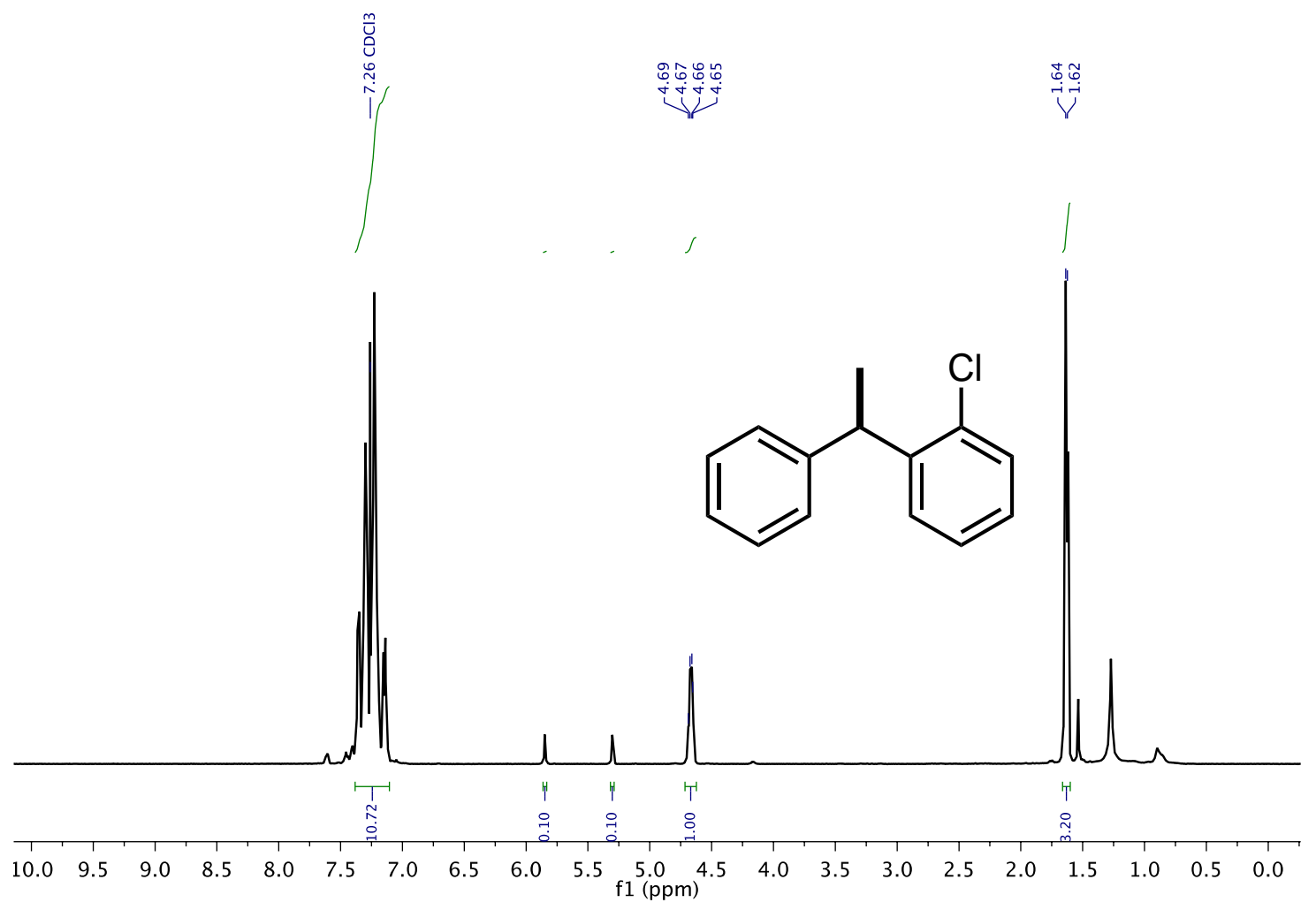

${ }^{1} \mathrm{H}$ NMR spectrum of (+)-1-phenyl-1-(o-chlorophenyl)-ethane (10b).

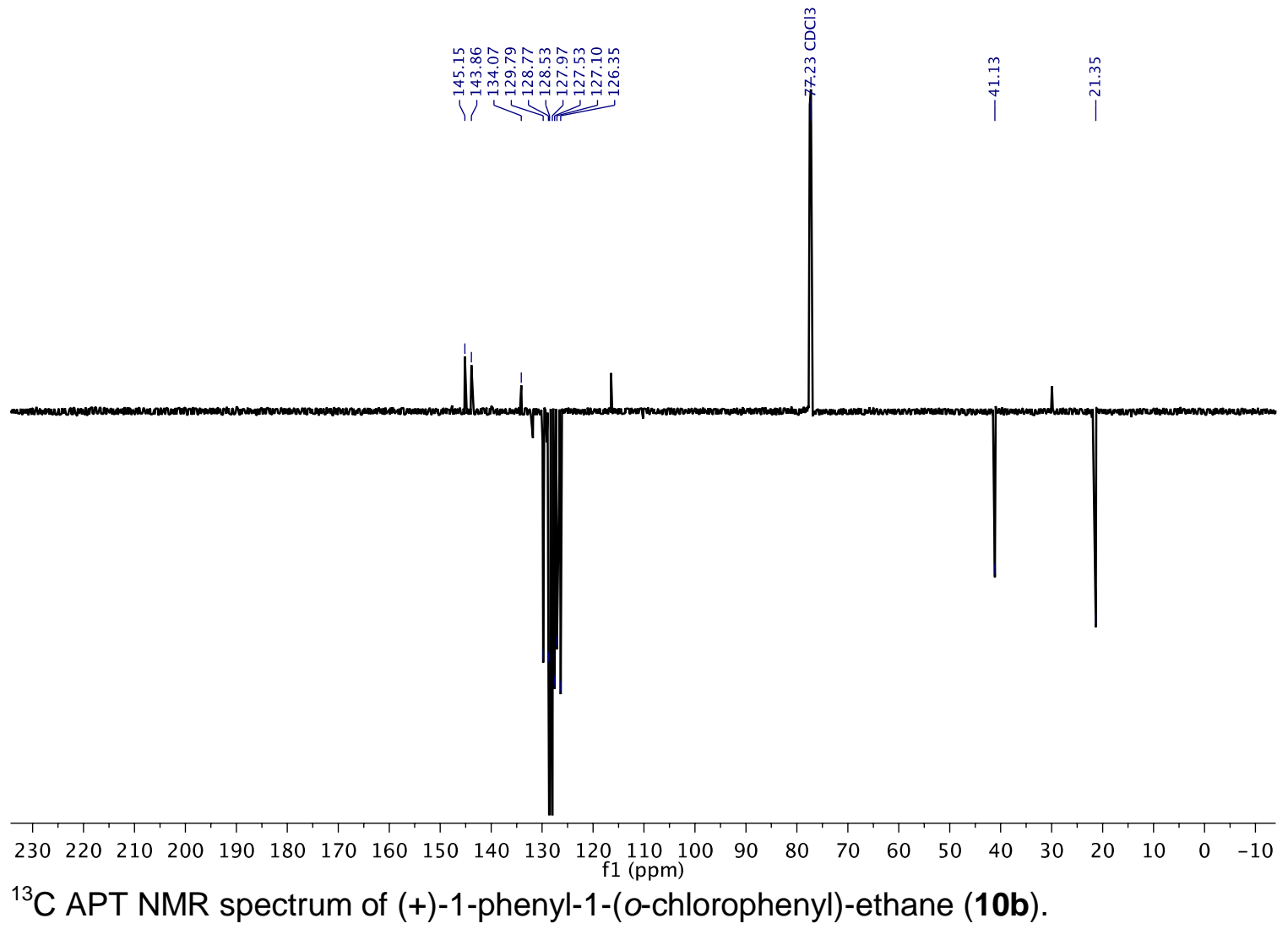




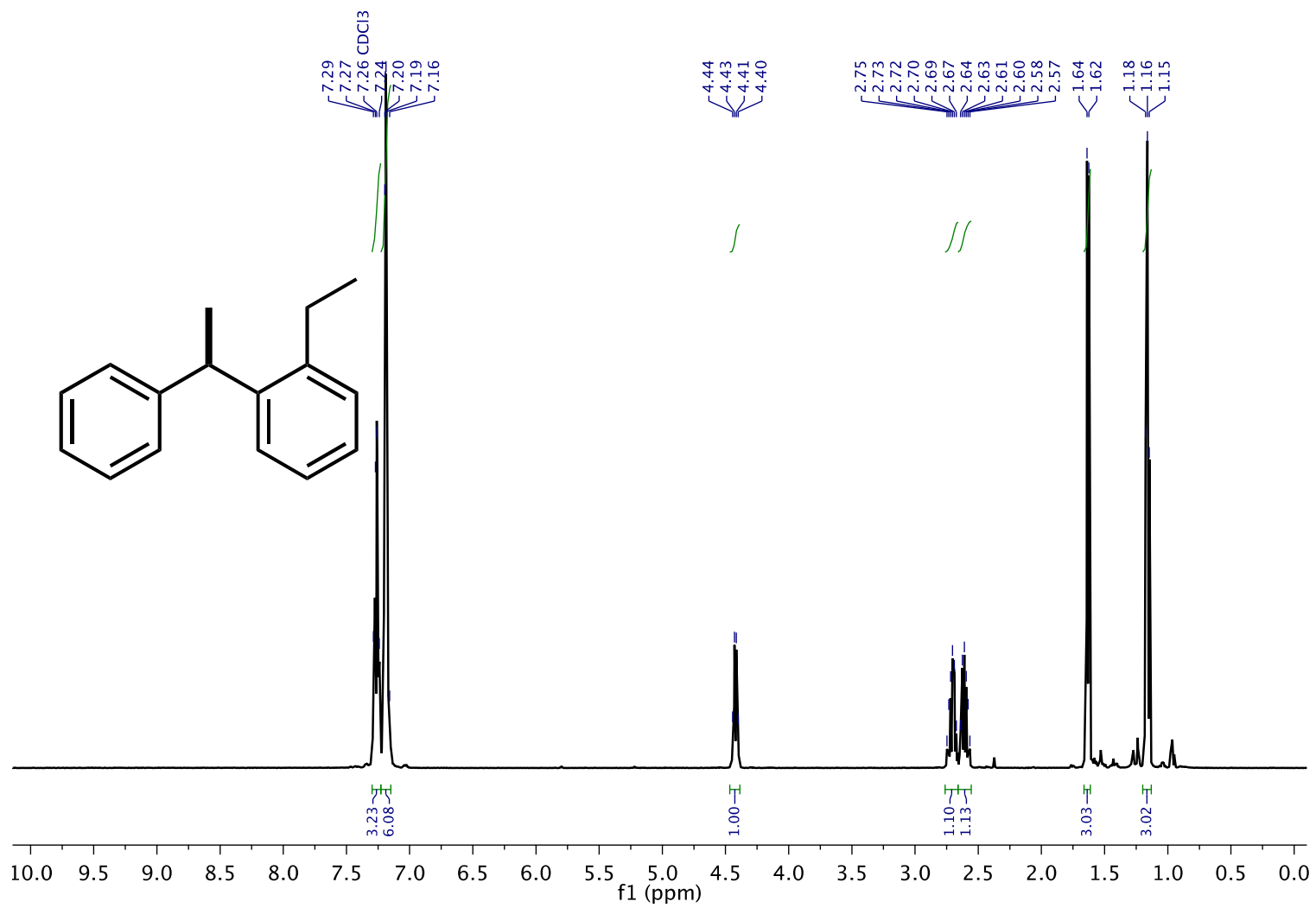

${ }^{1} \mathrm{H}$ NMR spectrum of (+)-1-phenyl-1-(o-ethylphenyl)-ethane (10c).

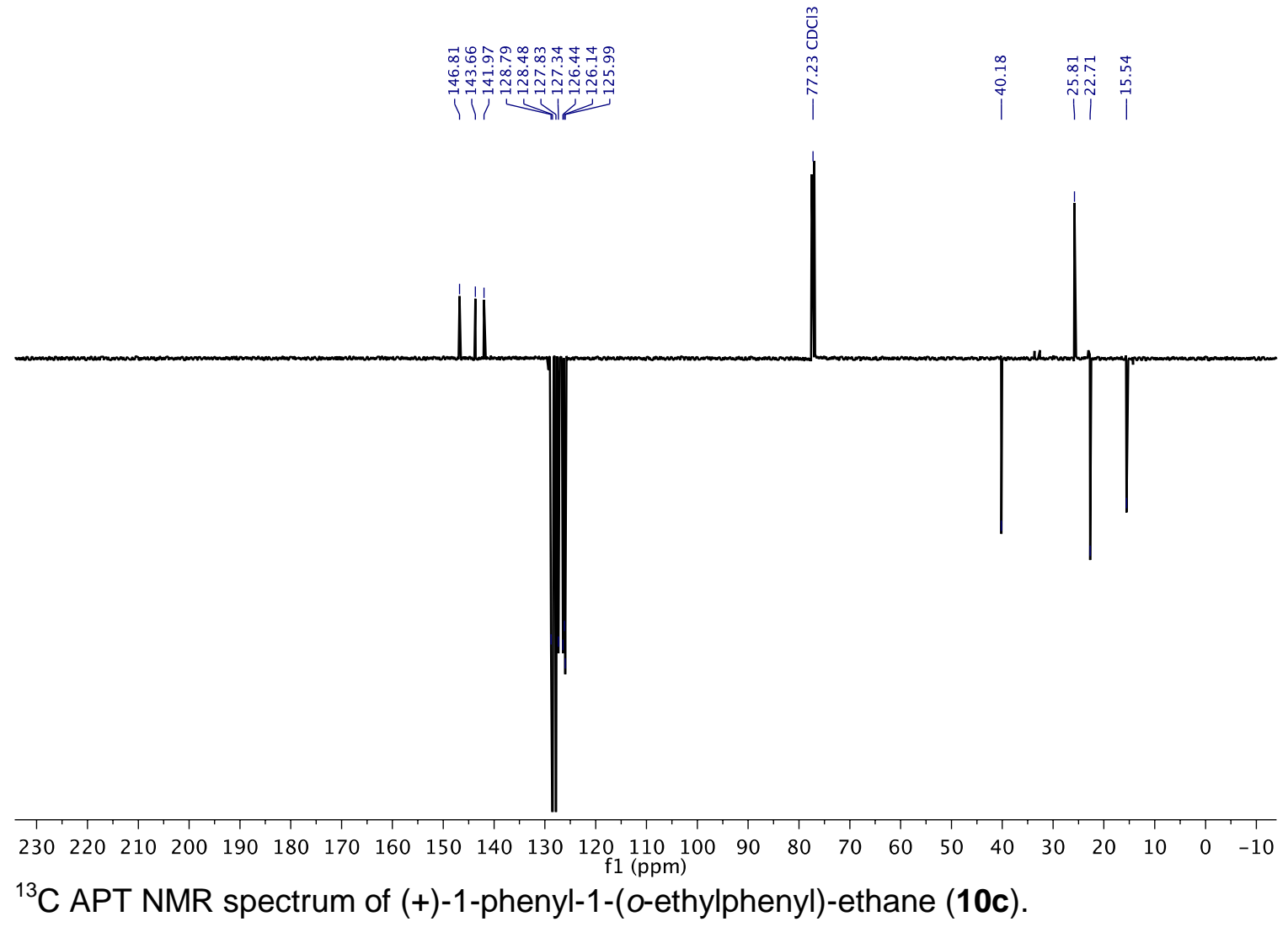




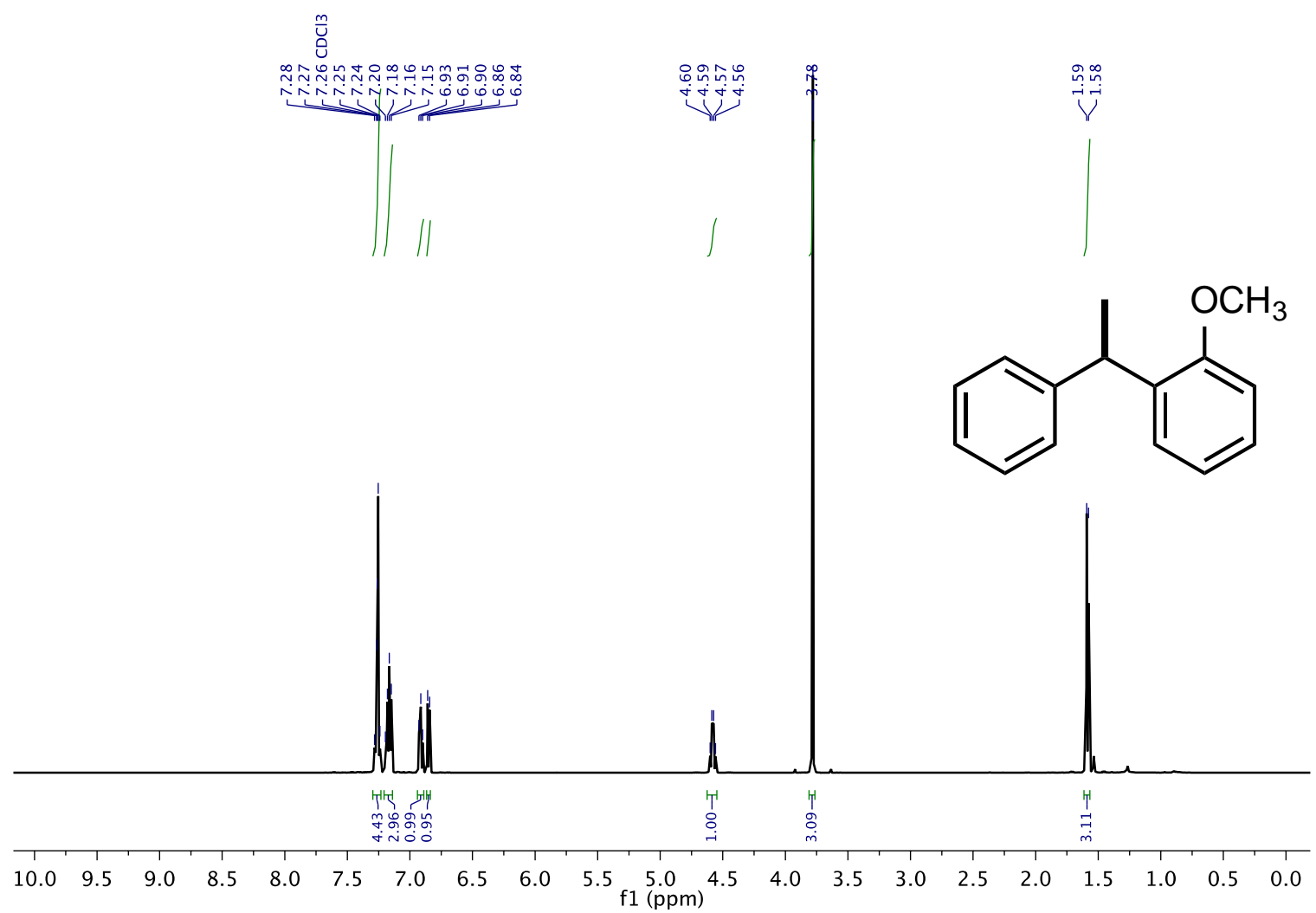

${ }^{1} \mathrm{H}$ NMR spectrum of (+)-1-phenyl-1-(o-methoxyphenyl)-ethane (10d).
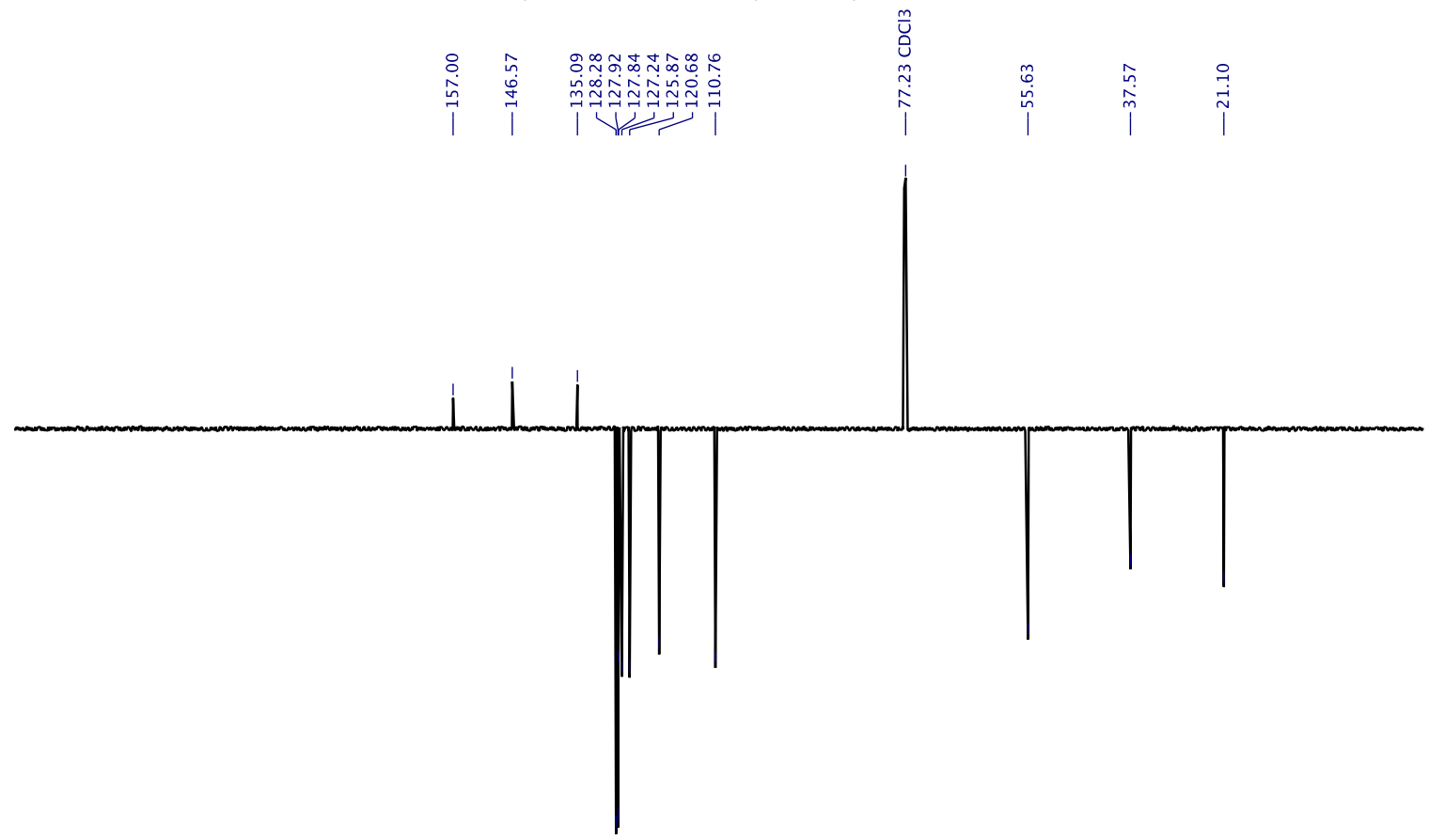

$\begin{array}{lllllllllllllllllllllllllllllllll}230 & 220 & 210 & 200 & 190 & 180 & 170 & 160 & 150 & 140 & 130 & 120 & 110 & 100 & 90 & 80 & 70 & 60 & 50 & 40 & 30 & 20 & 10 & 0 & -10\end{array}$ ${ }^{13} \mathrm{C}$ APT NMR spectrum of (+)-1-phenyl-1-(o-methoxyphenyl)-ethane (10d). 


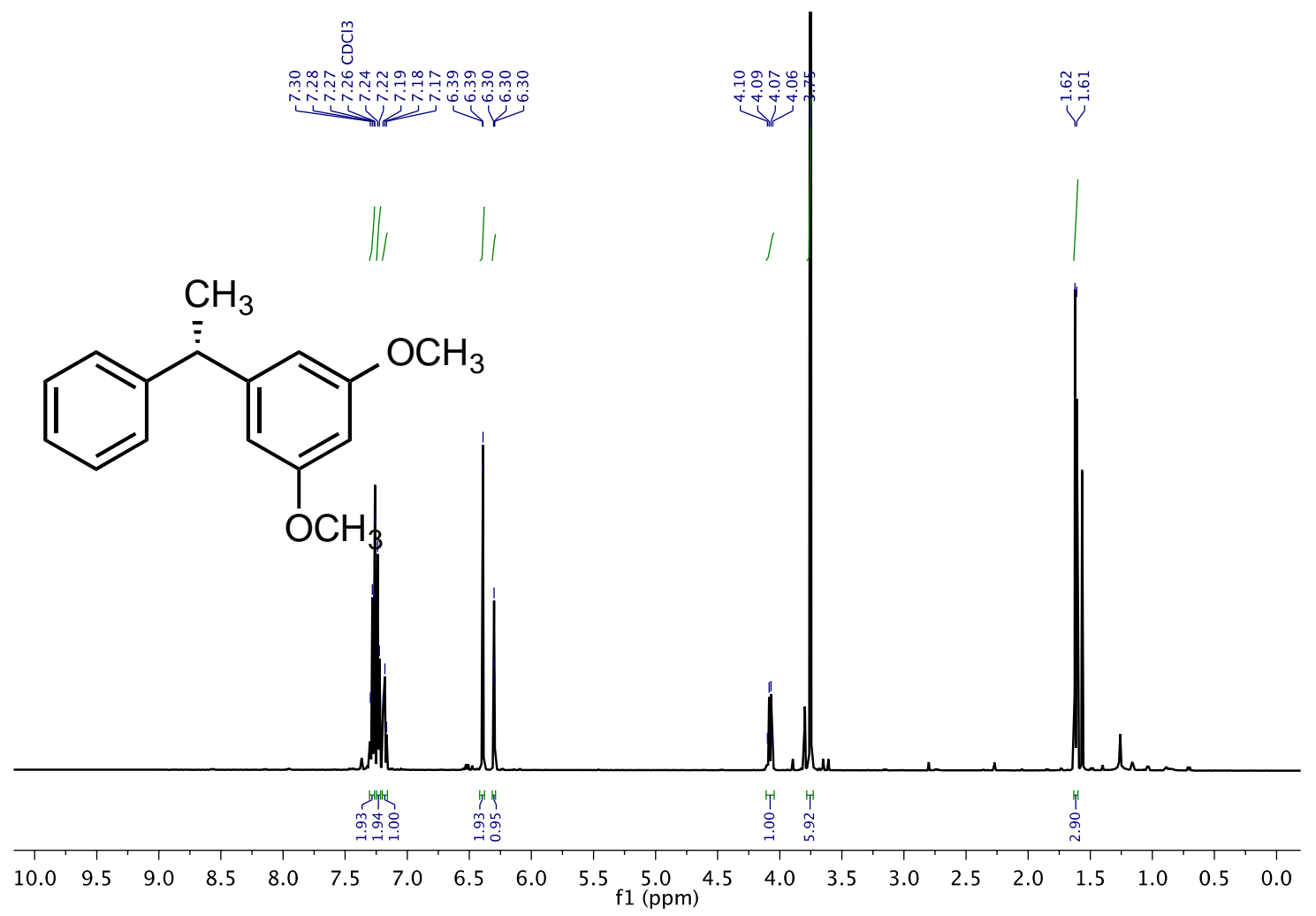

${ }^{1} \mathrm{H}$ NMR spectrum of 1-phenyl-1-(m,m-dimethoxyphenyl)-ethane (12).
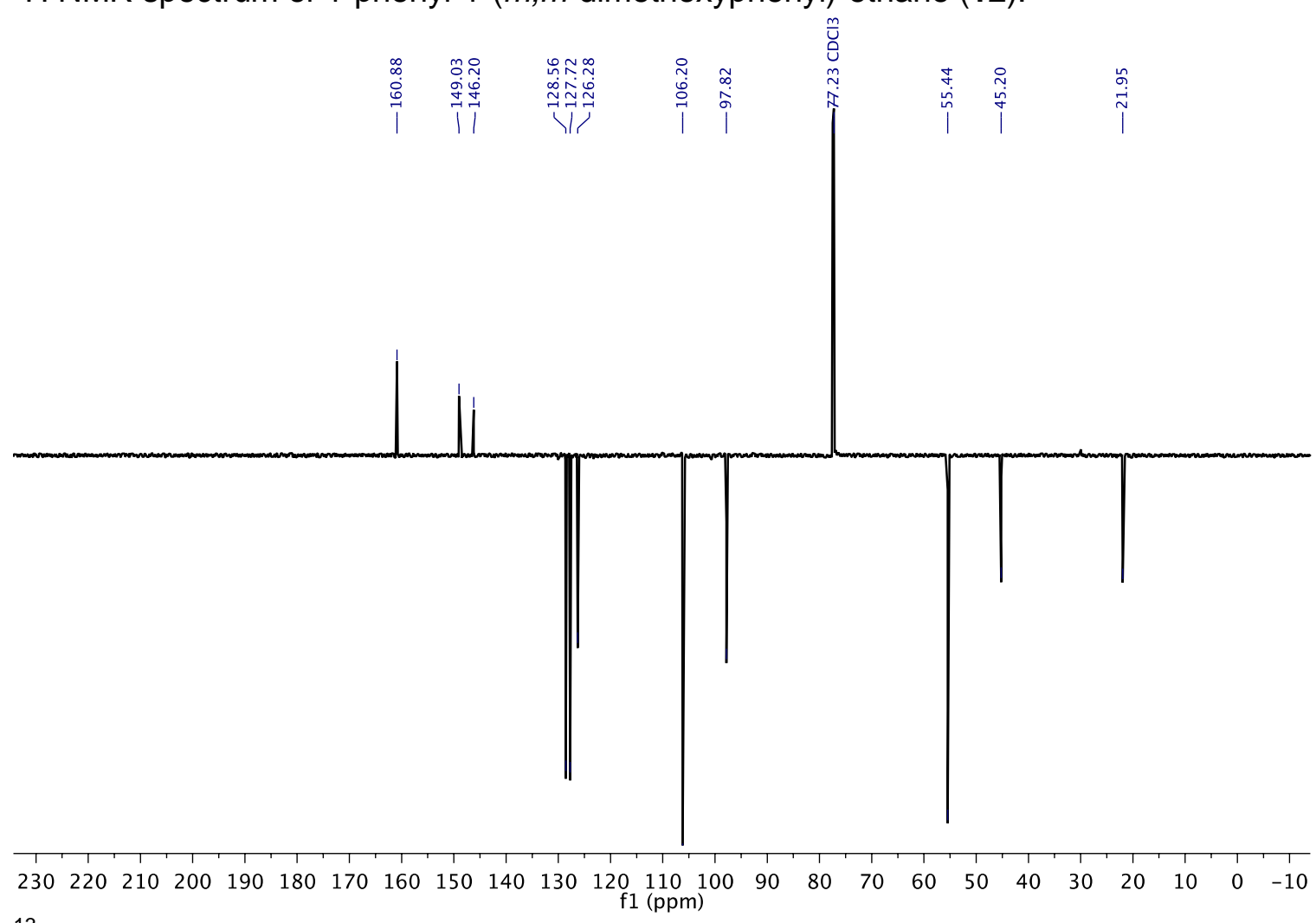

${ }^{13} \mathrm{C}$ APT NMR spectrum of 1-phenyl-1-(m,m-dimethoxyphenyl)-ethane (12). 


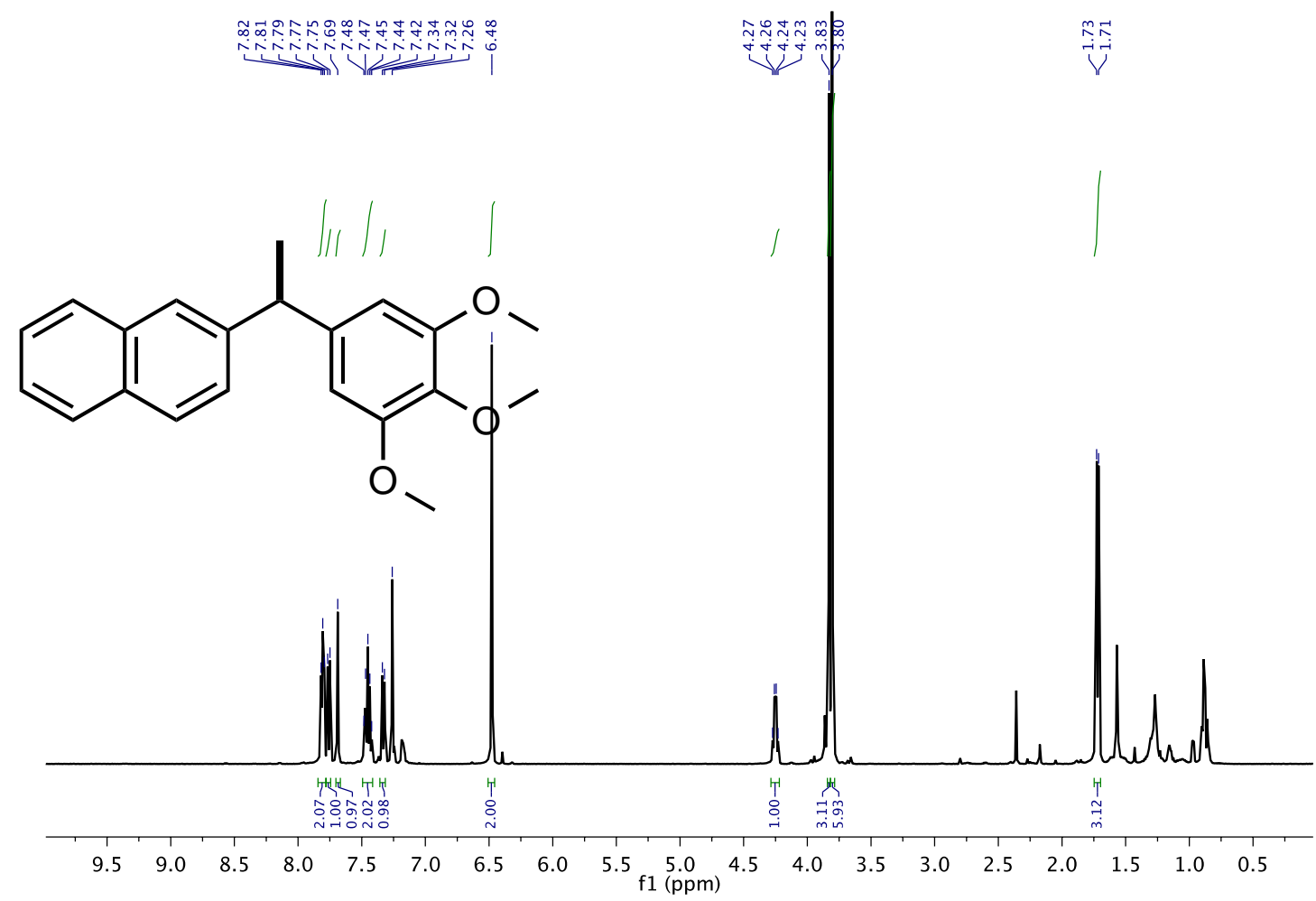

${ }^{1} \mathrm{H}$ NMR spectrum of 1-(2'-naphthyl)-1-(m,m,p-trimethoxylphenyl)-ethane (14).

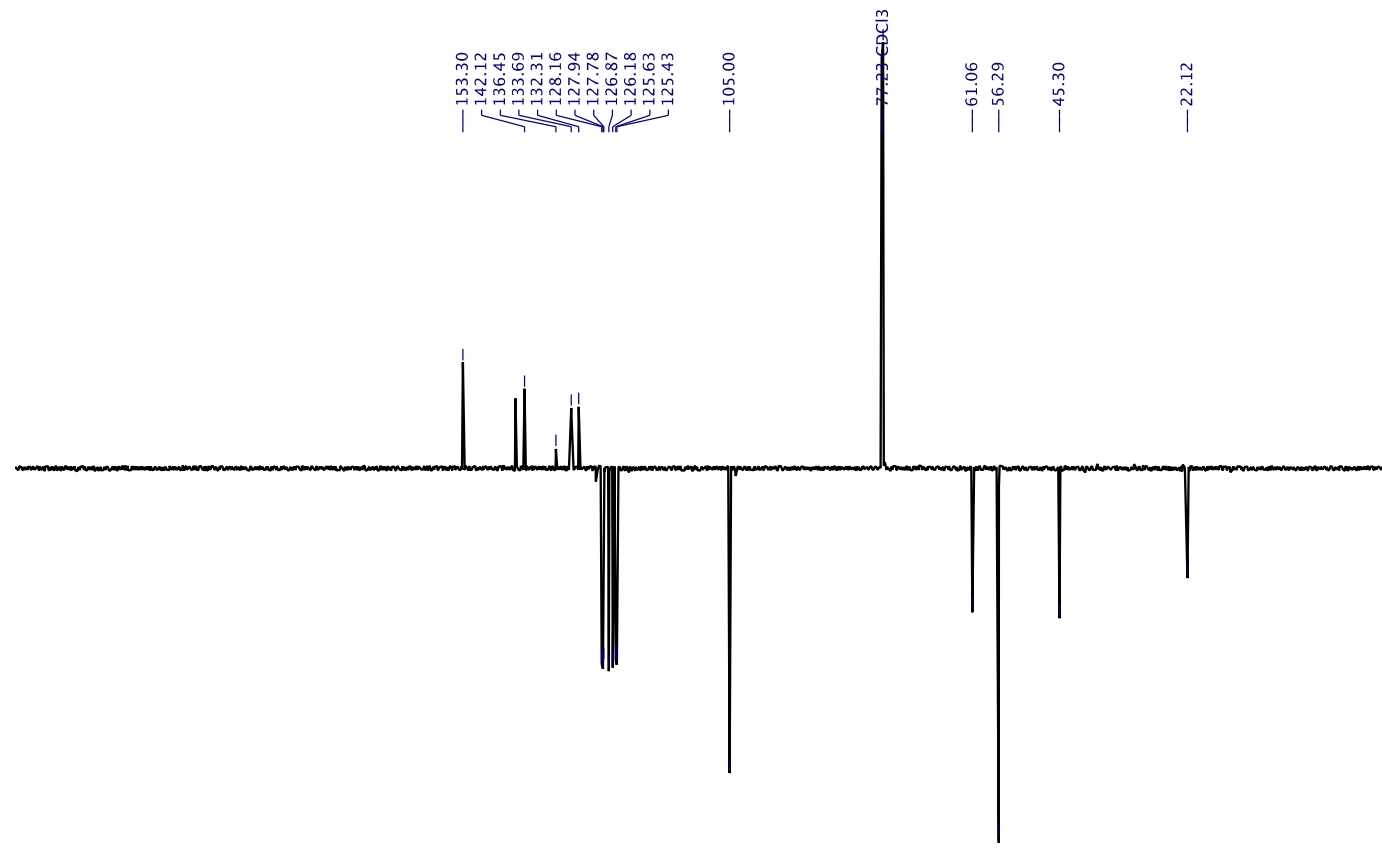

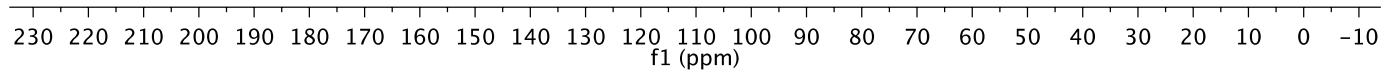

${ }^{13} \mathrm{C}$ APT NMR spectrum of 1-(2'-naphthyl)-1-(m,m,p-trimethoxylphenyl)-ethane (14). 


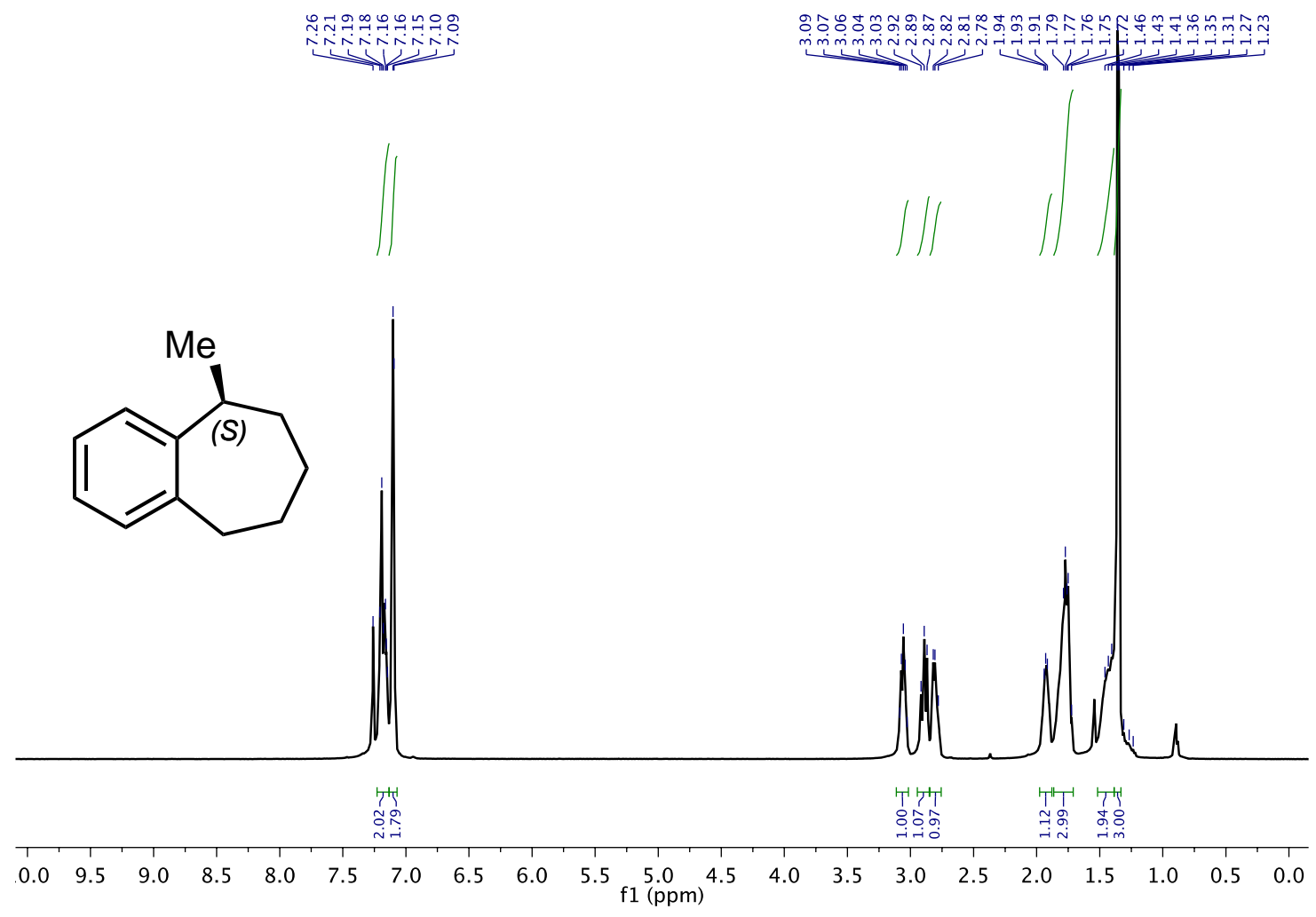

${ }^{1} \mathrm{H}$ NMR spectrum of (S)-(-)-1-methylbenzosuberan (16).

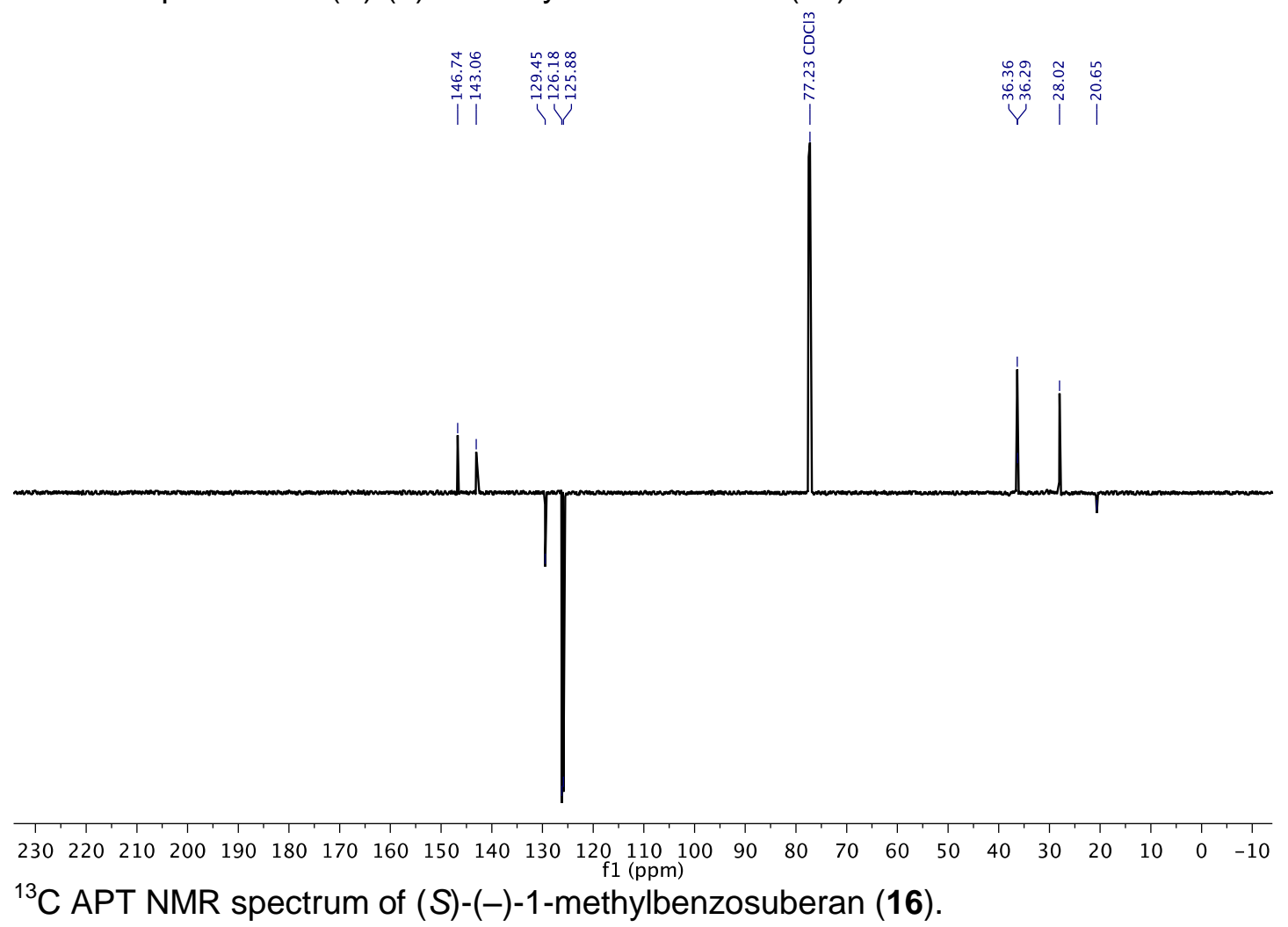




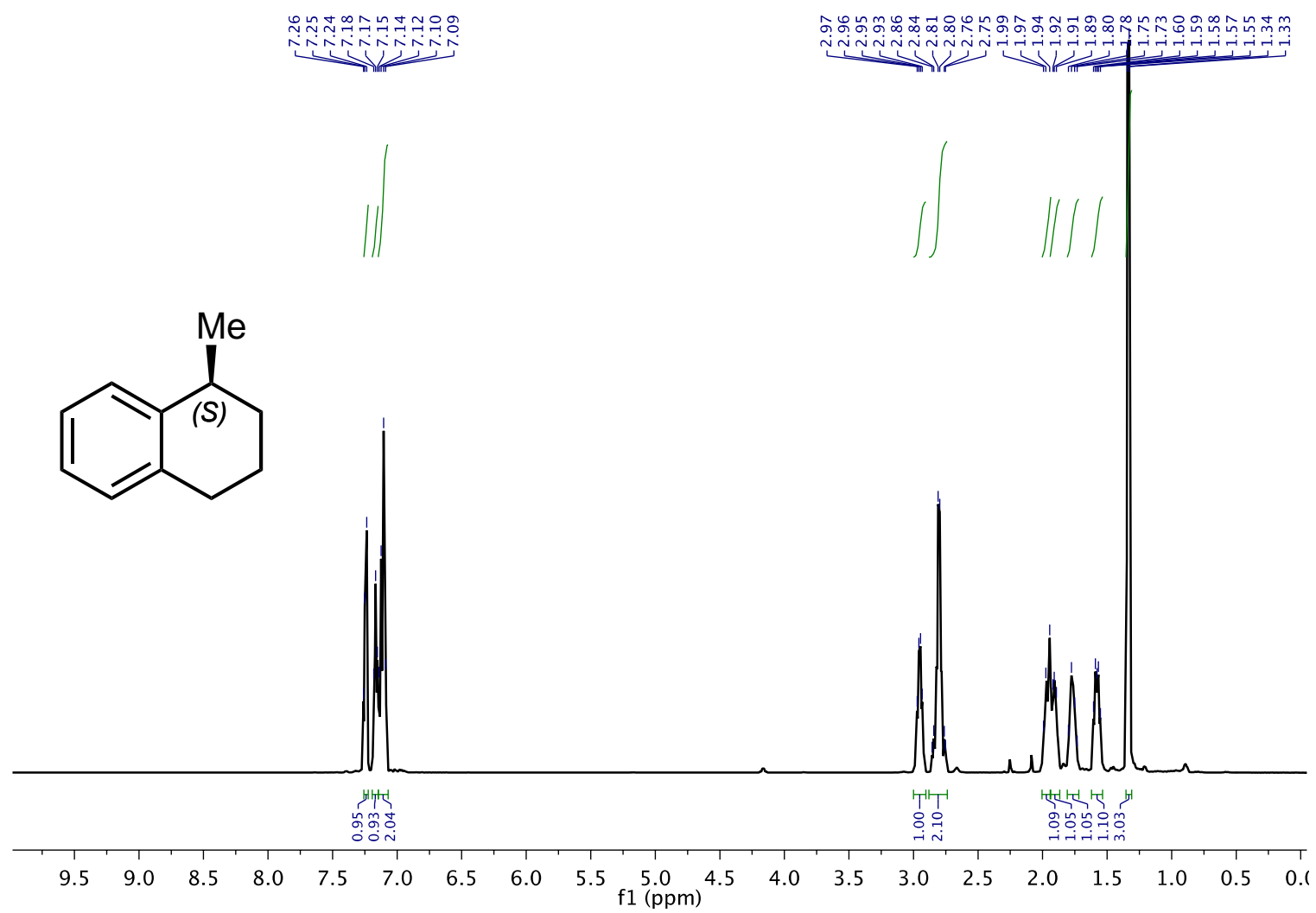

${ }^{1} \mathrm{H}$ NMR spectrum of $(S)-(+)-1$-methyltetralin (18).

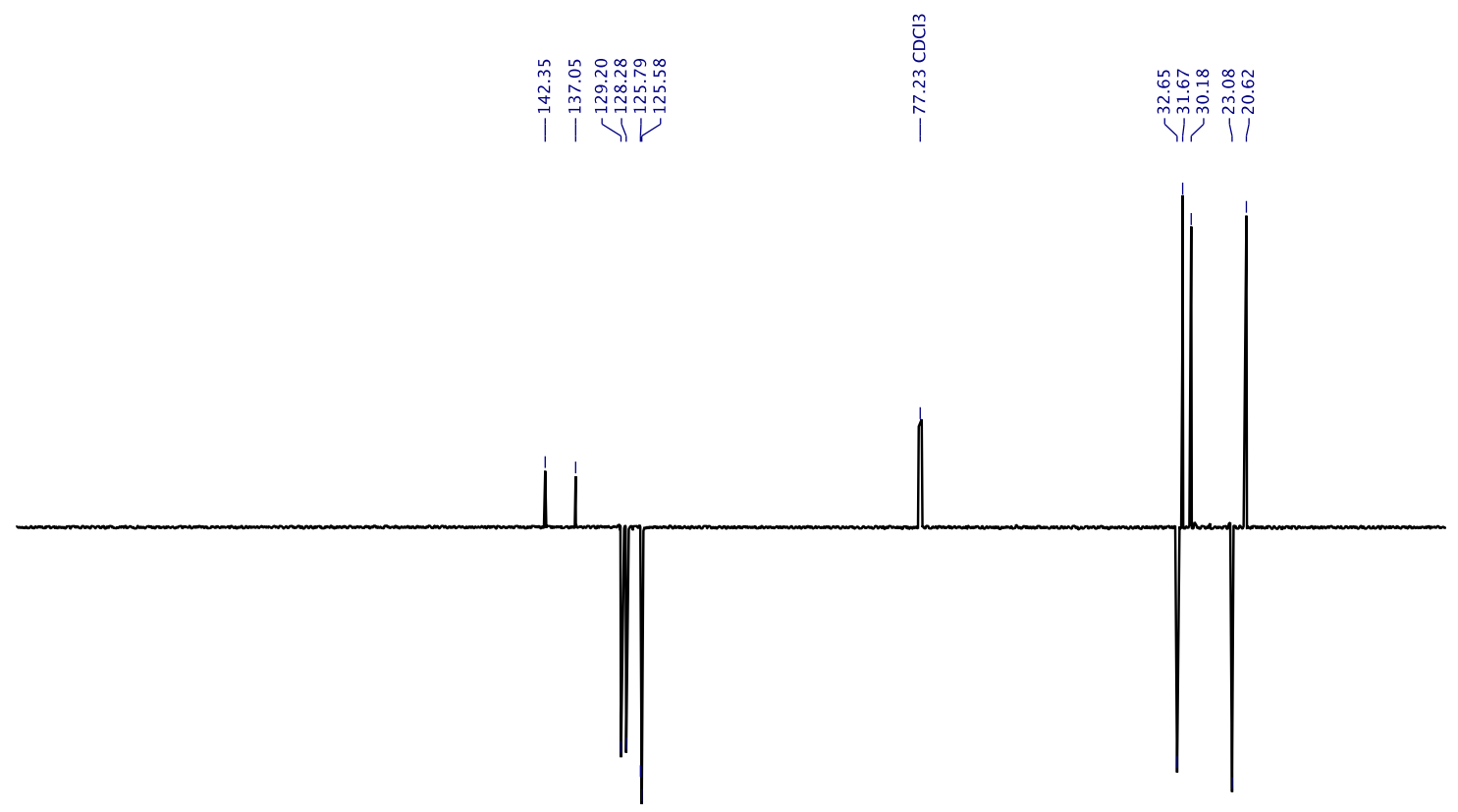

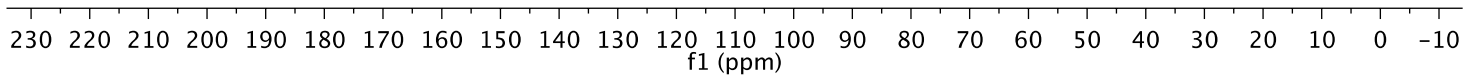

${ }^{13} \mathrm{C}$ NMR spectrum of $(S)-(+)-1-$ methyltetralin (18). 


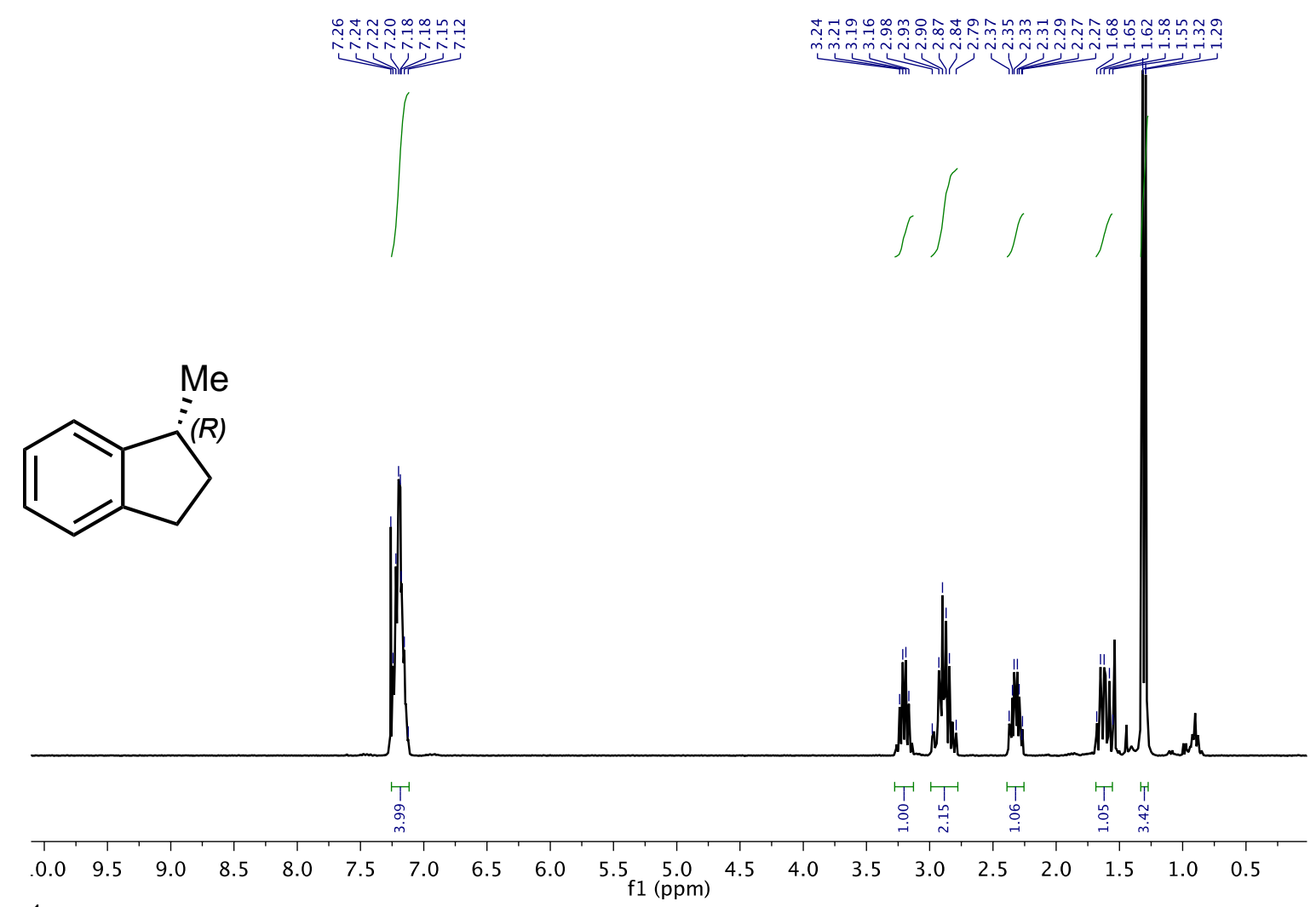

${ }^{1} \mathrm{H}$ NMR spectrum of $(R)-(+)-1$-methylindane (20).

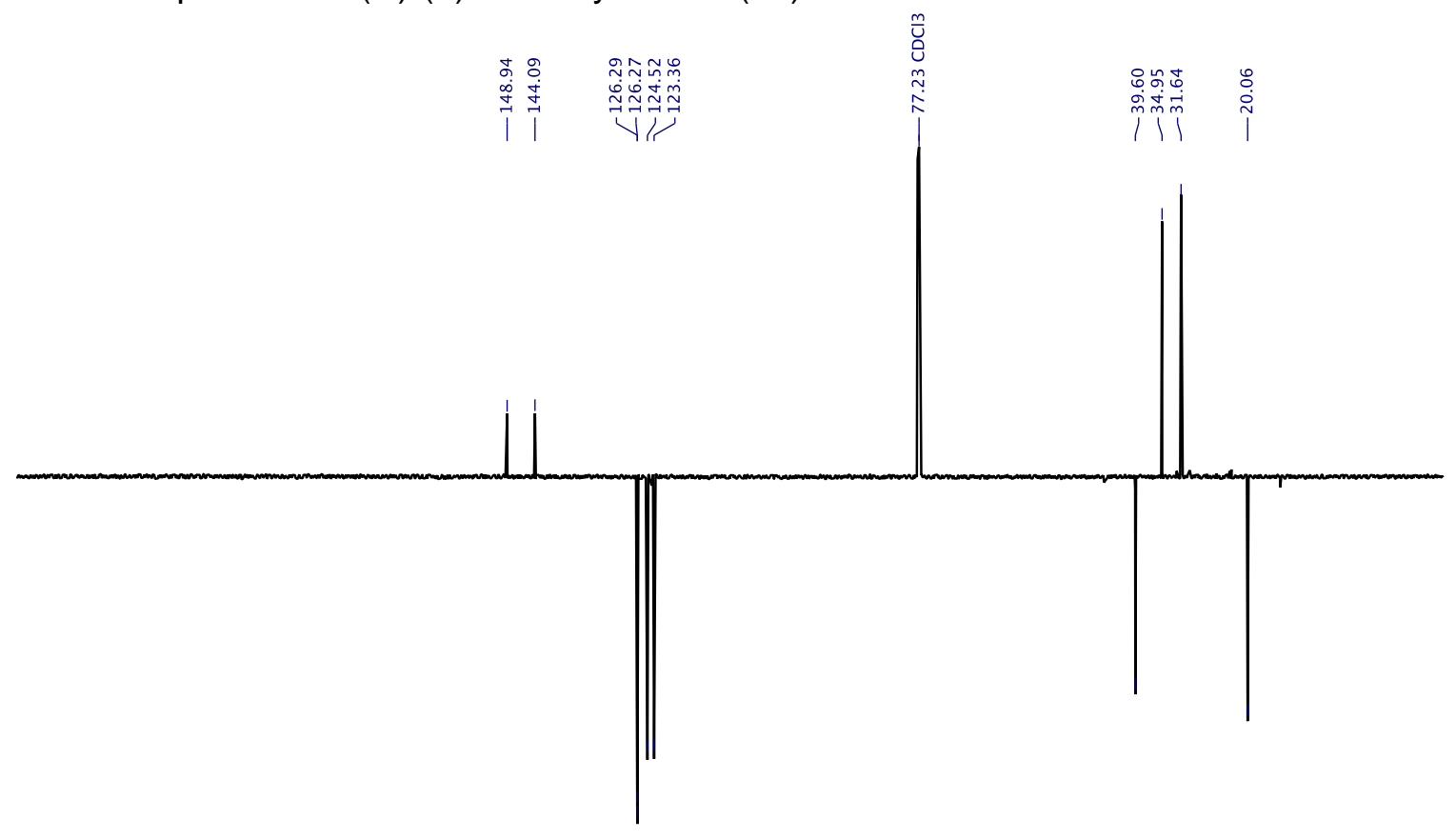

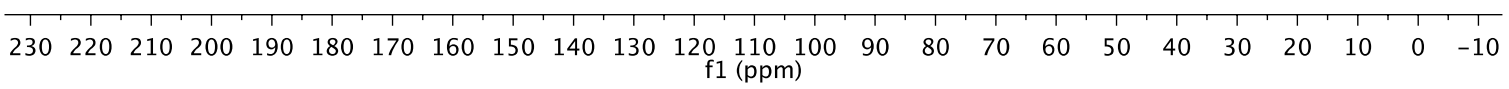
${ }^{13} \mathrm{C}$ APT NMR spectrum of $(R)-(+)-1$-methylindane $(20)$. 

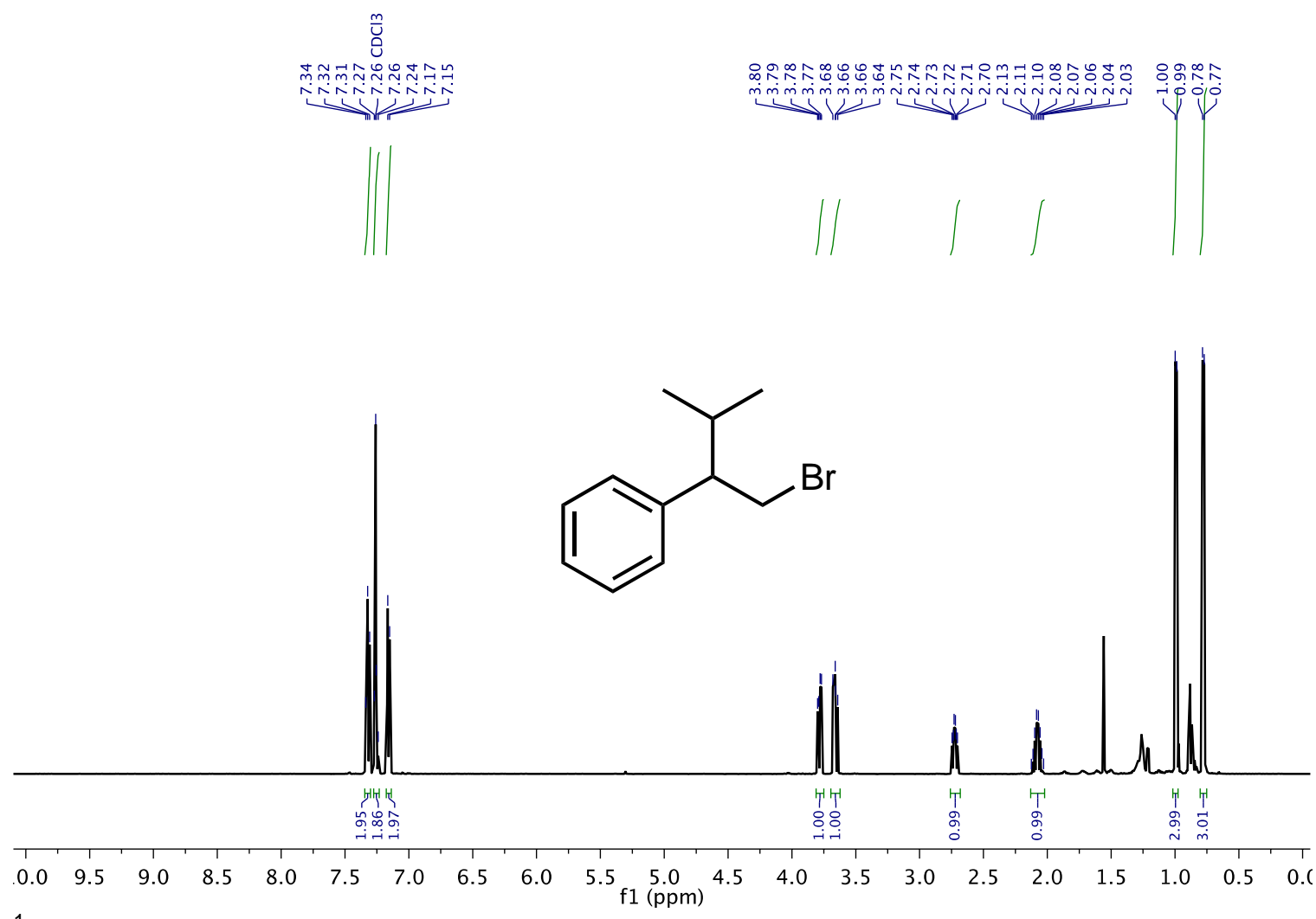

${ }^{1} \mathrm{H}$ NMR spectrum of 1-bromo-2-phenyl-3-methylbutane. 


\section{References.}

1. Pangborn, A. B.; Giardello, M. A.; Grubbs, R. H.; Rosen, R. K.; Timmers, F. J. Organometallics 1996, 15, 1518.

${ }^{2}$ Monfette, S.; Turner, Z. R.; Semproni, S. P.; Chirik, P. J. J. Am. Chem. Soc. 2012, 134, 4561.

${ }^{3}$ Tenaglia, A.; Jeune, K. L.; Giordano, L.; Buono, G. Org. Lett. 2011, 13, 636.

${ }^{4}$ Dreier, T.; Fröhlich, R.; Erker, G. J. Organomet. Chem. 2001, 621, 197.

${ }^{5}$ Arnold, D. R.; Du, X.; Henseleit, K. M. Can. J. Chem., 1991, 69, 839.

${ }^{6}$ Vila, C.; Giannerini, M.; Hornillos, V.; Fañanás-Mastral, M.; Feringa, B. L. Chem. Sci. 2014, 5, 1361.

${ }^{7}$ Greifenstein, L. G.; Labert, J. B.; Nienhuis, R. J.; Fried, H. E.; Pagani, G. A. J. Org. Chem. 1981, 46, 5125.

${ }^{8}$ Saito, S.; Sato, Y.; Ohwada, T.; Shudo, K. J. Am. Chem. Soc. 1994, 116, 1779.

${ }^{9}$ Xu, L.; Li, B.-J.; Wu, Z.-H.; Lu, X.-Y.; Guan, B.-T.; Wang, B.-Q.; Zhao, K.-Q.; Shi, Z.-J. Org. Lett. 2010, 12, 884.

${ }^{10}$ Tallineau, J.; Bashiardes, G.; Coustard, J.-M.; Lecornue, F. Synlett. 2009, 17, 2761.

${ }^{11}$ Schrems, M. G.; Pfaltz, A. Chem. Commun. 2009, 6210.

${ }^{12}$ Hamze, A.; Brion, J.-D.; Alami, M. Org. Lett. 2012, 14, 2782.

${ }^{13}$ Alacid, E.; Nájera, C. Org. Lett. 2008, 10, 5011.

${ }^{14}$ Ganapathy, D.; Sekar, G. Org. Lett. 2014, 16, 3856.

${ }^{15}$ Bess, E. N.; Sigman, M. S. Org. Lett. 2013, 15, 646.

${ }^{16}$ Hamze, A.; Giraud, A.; Messaoudi, S.; Provot, O.; Peyrat, J.-F.; Bignon, J.; Liu, J.-M.; Wdzieczak-Bakala, J.; Thoret, S.; Dubois, J.; Brion, J.-D.; Alami, M. ChemMedChem, 2009, 4, 1912.

${ }^{17}$ Hisano, M.; Takeda, K.; Takashima, T.; Jin, Z.; Shiibashi, A.; Matsumoto, A. Macromolecules 2013, 46, 3314.

18 Ohta, T.; Ikegami, H.; Miyake, T.; Takaya, H. J. Organomet. Chem. 1995, 502, 169.

${ }^{19}$ Purohit, V. C.; Allwein, S. P.; Bakale, R. P. Org. Lett. 2013, 15, 1650.

${ }^{20}$ Soicke, A.; Slavov, N.; Neudörfl, J.-M.; Schmalz, H.-G. Synlett, 2011, 17, 2487. 
${ }^{21}$ Firmansjah, L.; Fu. G. C. J. Am. Chem. Soc. 2007, 129, 11340.

${ }^{22}$ Ortega, N.; Beiring, B.; Urban, S.; Glorius, F. Tetrahedron, 2012, 68, 5185.

${ }^{23}$ Villaseñor, E.; Gutierrez-Gonzalez, R.; Carrillo-Hermosilla, F.; Fernández-Galán, R.; López-Solera, I.; Fernández-Pacheco, A. R.; Antiñolo, A. Eur. J. Inorg. Chem. 2013, 2013, 1184.

${ }^{24}$ Kangani, C. O.; Day, B. W. Org. Lett. 2008, 10, 2645.

${ }^{25}$ Odedra, A.; Datta, S.; Liu, R.-S. J. Org. Chem. 2007, 72, 3289.

${ }^{26}$ Pauli, R. Tannert, R. Scheil, A. Pfaltz, Chem. Eur.-J. 2014, 21, 1482.

${ }^{27}$ Ortega, N.; Urban, S.; Beiring, B.; Glorius, F. Angew. Chem. Int. Ed. 2012, 51, 1710.

${ }^{28}$ Kraus, G. A.; Schroeder, J. D. Syn. Lett. 2005, 16, 2504.

${ }^{29}$ Moure, M. J.; SanMartin, R.; Dominguez, E. Angew. Chem. Int. Ed. 2012, 51, 3220.

${ }^{30}$ Schrems, M. G.; Neumann, E.; Pfaltz, A. Angew. Chem. Int. Ed. 2007, 46, 8274.

${ }^{31}$ McMurry, J. E.; Fleming, M. P.; Kees, K. L.; Krepski, L. R. J. Org. Chem. 1978, 43, 3255.

${ }^{32}$ Rennison, D.; Bova, S.; Cavalli, M.; Ricchelli, F.; Zulian, A.; Hopkins, B.; Brimble, M. A. Bioorg. Med. Chem. 2007, 15, 2963.

${ }^{33}$ Schubert, R.; Grützmacher, H.-F. J. Am. Chem. Soc. 1980, 102, 5323.

34. (a) Deng, R.; Sun, L.; Li, Z. Org. Lett. 2007, 9, 5207. (b) Hixson, S.S.; Franke, L. A. J. Org. Chem. 1988, 53, 2706.

35. Rueping, M.; Nachtsheim, B. J.; Scheidt, T. Org. Lett. 2006, 8, 3717.

36. Hu, X.; Martin, D.; Melaimi, M.; Bertrand, G. J. Am. Chem. Soc. 2014, 136, 13594.

37. Bencze, W. L.; Kisis, B.; Puckett, R. T.; Finch, N. Tetrahedron, 1970, 26, 5407.

38. Hong, B.-C.; Nimje, R. Y.; Liao, J.-H. Org. Biomol. Chem. 2009, 7, 3095.

${ }^{39}$ Bright, S. T.; Coxon, J. M.; Steel, P. J. J. Org. Chem. 1990, 55, 1338.

${ }^{40}$ Qu, B.; Samankumara, L. P.; Ma, S.; Fandrick, K. R.; Desrosiers, J.-N.; Rodriquez, S.; Li, Z.; Haddad, N.; Han, Z. S.; McKellop, K.; Pennino, S.; Grinberg, N.; Gonnella, N. C.; Song, J. J.; Senanayake. C. H. Angew. Chem. Int. Ed. 2014, 53, 14428.

41. Schneider, M. R.; Schiller, C. D. Arch. Pharm. 1990, 323, 17. 
42. Lightfoot, A.; Schnider, P.; Pfaltz, A. Angew. Chem. Int. Ed. 1998, 37, 2897.

43. Friedfeld, M. R.; Shevlin, M.; Hoyt, J. M.; Krska, S. W.; Tudge, M. T.; Chirik, P. J. Science, 2013, 342, 1076.

44. Imao, D.; Glasspoole, B. W.; Laberge, V. S.; Crudden, C. M. J. Am. Chem. Soc. 2009, $131,5024$.

45. Taylor, B. L. H. ; Swift, E. C.; Waetzig, J. D.; Jarvo, E. R. J. Am. Chem. Soc. 2010, 133, 389.

46. Nelson, N. A.; Fassnacht, J. H.; Piper, J. U. J. Am. Chem. Soc. 1961, 83, 206.

47. Barry, J.; Kagan, H.-B.; Snatzke, G. Tetrahedron, 1971, 27, 4737.

48. Broene, R. D.; Buchwald, S. L. J. Am. Chem. Soc. 1993, 115, 12569.

49. Smith, H. E.; Padilla, B. G.; Neergaard, J. R.; Chen, F.-M. J. Am. Chem. Soc. 1978, 100, 6035.

${ }^{50}$ Adam, W.; Bosio, S. G.; Turro, N. J.; Wolff, B. T. J. Org. Chem. 2004, 69, 1704. See page S2-S3 in Supporting Information.

${ }^{51}$ Sonnet, P. E.; Oliver, J. E. J. Org. Chem. 1976, 41, 3279.

52 (a) De Luca, L.; Giacomelli, G.; Porcheddu, A. Org. Lett. 2002, 4, 553. (b) Branca, Q.; Edenhofer, A.; Gutknecht, E. M.; Neidhart, W.; Ramuz, H.; Wostl, W. Preparation and testing of peptide analogues as renin inhibitors. U.S. Patent 5,250,517, Oct $5^{\text {th }}, 1993$.

${ }^{53}$ Krasovskiy, A.; Knochel, P. Synthesis, 2006, 890. 